Bulletin 117

DEPARTMENT OF THE INTERIOR

JOHN BARTON PAYNE, SEcretary

BUREAU OF MINES

FREDERICK G, COTTRELL, DIRECTOR

\title{
STRUCTURE IN PALEOZOIC BITUMINOUS COALS
}

BY

REINHARDT THIESSEN

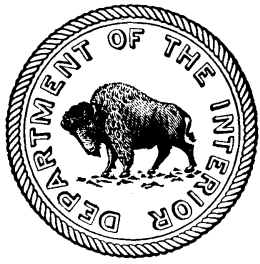

WASHINGTON

GOVERNMENT PRINTING OFFICE 1920 
The Bureau of Mines in carrying out one of the provisions of its organic act-to disseminate information concerning investigations made-prints a limited free edition of each of its publications.

When this edition is exhausted, copies may be obtained at cost price only through the Superintendent of Documents, Government Printing Office, Washington, D. C.

The Superintendent of Documents is not an official of the Bureau of Mines. His is an entirely separate office and he should be addressed:

\section{SUPERINTENDENT OF Documents, \\ Government Printing Office, \\ Washington, D. C.}

The general law under which publications are distributed prohibits the giving of more than one copy of a publication to one person. The price of this publication is 80 cents.

Persons desiring for lecture purpose the use, free of charge, of lantern slides of the illustrations in this publication, should make request of the Director of the Bureau of Mines, Washington, D. C.

First edition. August, 1920. 


\section{CONTENTS.}

Introduction

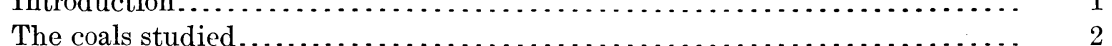

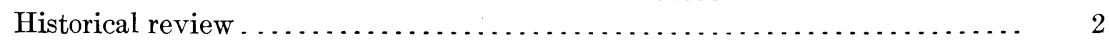

The woody structure in coal, and the meaning of the alternating dull and

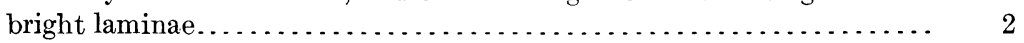

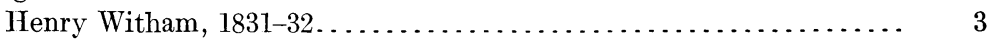

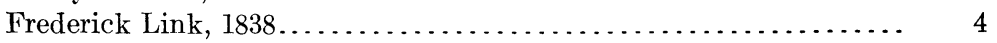

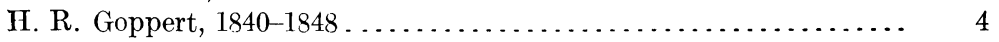

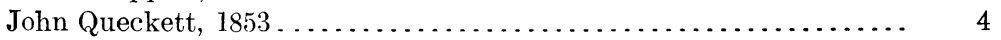

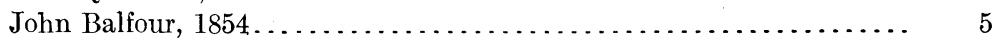

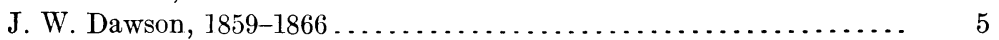

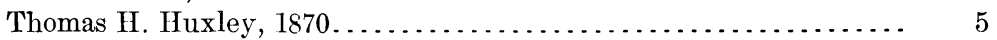

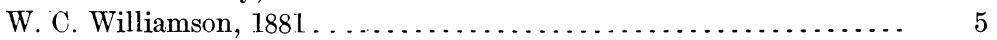

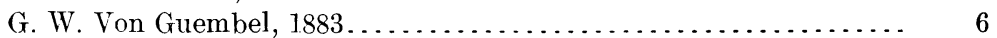

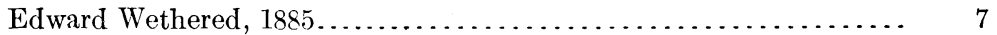

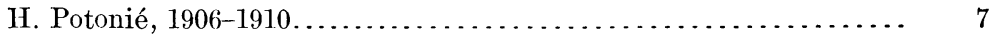

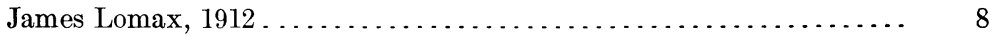

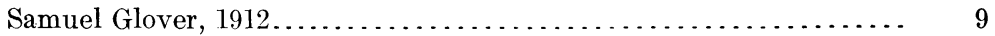

David White and Reinhardt Thiessen, $1914 \ldots \ldots \ldots \ldots \ldots \ldots \ldots . . . \ldots$

Edward C. Jeffrey, 1914-15............................ 9

George Hickling, 1917.................................. 10

ethods of examining samples................................ 10

Preparation of thin sections.............................. 10

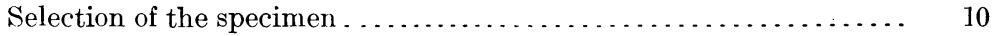

Preparation of the plane surface . . . . . . . . . . . . . . . . . . . 11

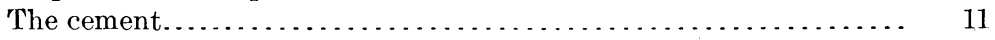

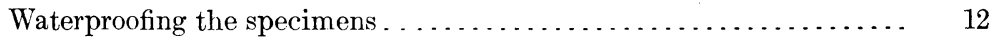

Cementing the block on the slide . . . . . . . . . . . . . . . . . . . 12

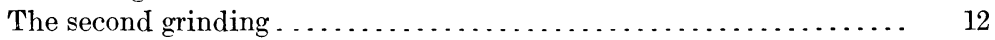

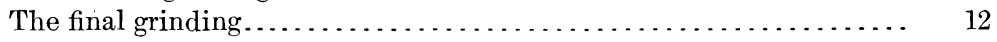

The preparation of polished surfaces for oblique illumination......... 12

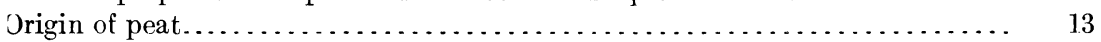

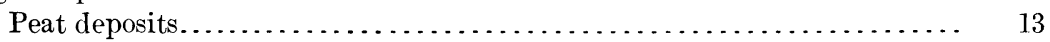

Occurrence............................................. 13

Disintegration of plant substances.......................... 14

Composition of a bog.................................... 16

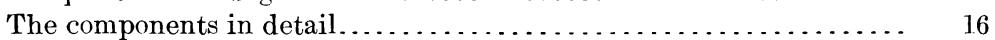

The attritus....................................... 16

Objects visible under a hand lens...................... 17

The smaller woody components....................... 17

Larger woody components........................... 17

Logs and larger parts of trees........................... 17

Proportions of components........................... 18

Spores, pollens, cuticles, and resins . . . . . . . . . . . . . . . 18

The amorphous constituents ........................ $\quad 19$

The physical structure of the tissues remaining in peat .......... 20

The cell walls in a state of hydrogel........................ 20

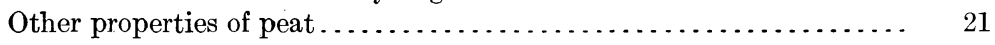

Preservation of plant tissues $\ldots, \ldots, \ldots, \ldots \ldots \ldots \ldots \ldots \ldots, 21$ 
Structure in coal .......................................... 22

General appearance under the microscope .................... 22

The lamination seen in coal............................ 22

The "bright coal" or anthraxylon .......................... 23

The "dull coal"........................................ 24

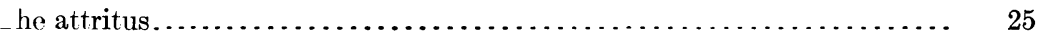

Examination of vertical sections at low magnification............... 25

Structure of the coal from the Benton mine, Benton, Ill ........... 26

Structure of the coal from Royalton, Ill..................... 27

Structure of the Zeigler and Hart-Williams coals............. 28

Structure of the coal from Sesser, Ill...................... 29

Structure of the coal from Buxton, Iowa................... 29

Structure of the Pittsburgh coal.......................... 29

Similarity of vertical sections of all coals..................... 31

Examination of horizontal cleavage surfaces................... 31

Structure of the Vandalia coal.............................. 32

Structure of the Benton and Hart-Williams coal. . . . . . . . . . . . 32

Structure of the coal from Sesser, Ill...................... 33

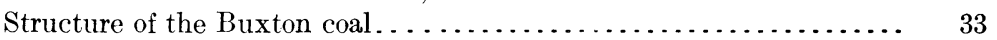

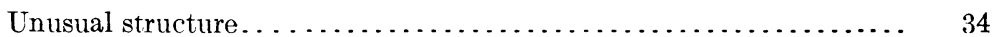

Similarity of horizontal cleavages of all coals............... 34

Correlation of the vertical sections and horizontal cleavages............ 34

Nature of the woody patches............................ 34

Origin of the woody patches............................. 35

Similarity between horizontal cleavage surfaces of coal and peat: A proof

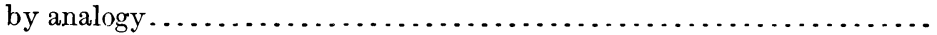

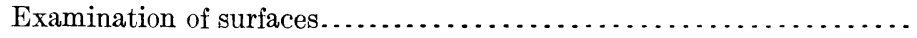

Dissection of horizontal cleavages. . . . . . . . . . . . . . . . . . .

Microscopic examination of coal. . . . . . . . . . . . . . . . . . . . . . . .

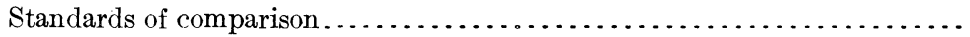

Correlation of characters. . . . . . . . . . . . . . . . . . . . . . . . .

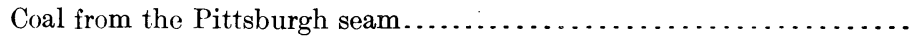

The Buxton coal........................................

The Vandalia coal . . . . . . . . . . . . . . . . . . . . . . . . .

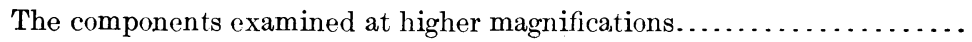

The bright coal or the larger anthraxylon components. . . . . . . . . .

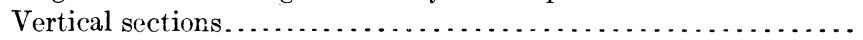

Horizontal sections. . . . . . . . . . . . . . . . . . . . . . . .

Preservation of structure . . . . . . . . . . . . . . . . . . . . . . . . .

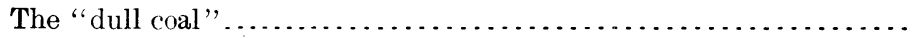

The smaller anthraxylon components...................

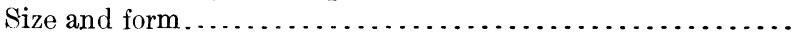

Distribution .......................................

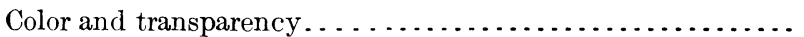

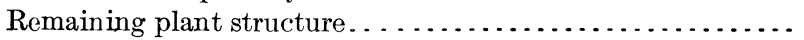

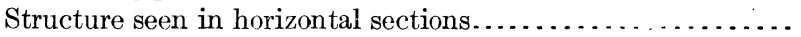

Reduction in thickness from the original of the anthraxylon.

Resinous inclusions.

The kinds of tissues represented in the coals............... 54

Cuticles........................................ 55

Cuticles in coal.................................. 55

Bark............................................ 56

The attritus.......................................... 57 
Microscopic examination of coal-Continued.

The components examined at higher magnifications-Continued.

The "dull coal"-Continued.

The Oak mine coal; cross sections................... 57

The Experimental mine coal; cross sections.............. 58

The Oak mine coal; horizontal sections................ 59

Experimental mine coal; horizontal sections............... 60

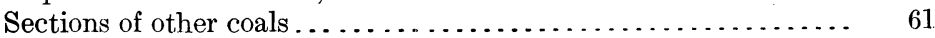

Illinois coals, from the No. 6 bed ................... 61

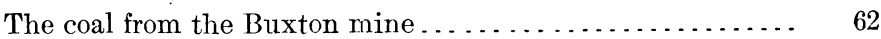

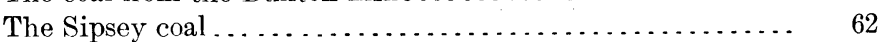

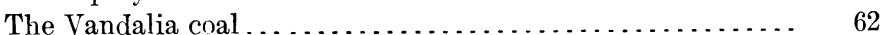

The Carbon Hill coal......................... 63

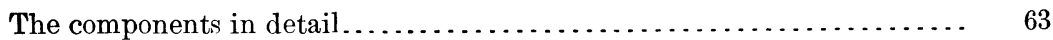

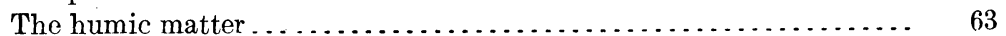

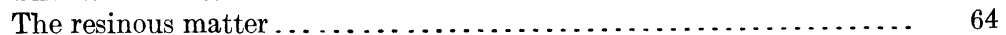

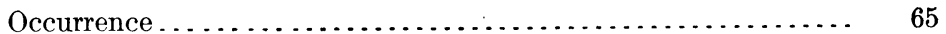

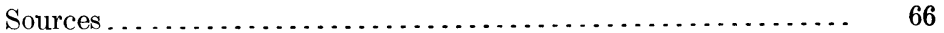

Distinguishing characteristics............................. 66

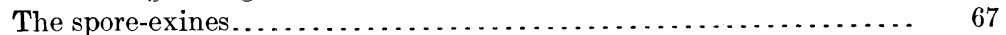

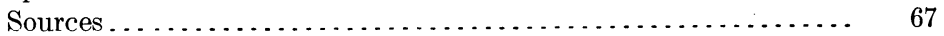

Tetrasporic markings and sculpturing...................... 69

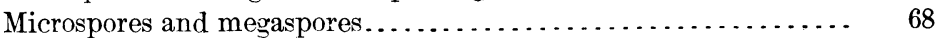

Distribution.................................... 79

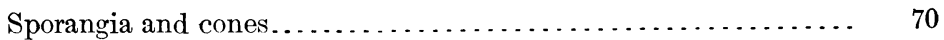

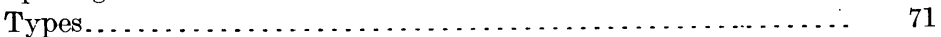

Grouping of coals by their spore-exines................. $\quad 72$

Spore-exines from the Pittsburgh seam . . . . . . . . . . . . . $\quad 72$

Spore-exines from the Sipsey mine... . . . . . . . . . . . . . 73

Spore-exines from the Buxton coal................... 74

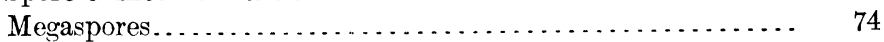

Predominant exines of the Shelbyville coal. . . . . . . . . 75

Spore-exines in the Illinois coals of bed No. $6 \ldots \ldots \ldots \ldots . . .76$

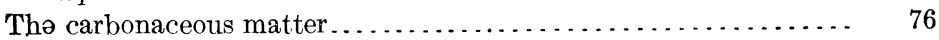

The more highly carbonized anthraxylon .............. $\quad 77$

The disorganized class of carbonized matter. ............ $\quad 77$

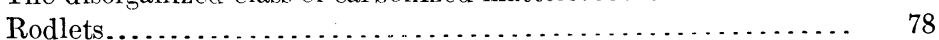

Rodlets scattered through the attritus............... 78

Rodlets associated with woody structures.............. . 79

The nature of the rodlets . . . . . . . . . . . . . . . 79

The origin of rodlets........................ 80

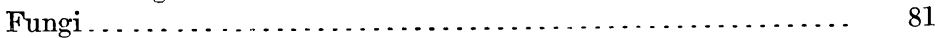

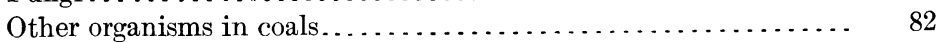

Comparison of the structures of the coals. . . . . . . . . . . . . . . . . . . 82

The coals from the Pittsburgh seam....................... 82

The coal from Carbon Hill, Alabama........................ 83

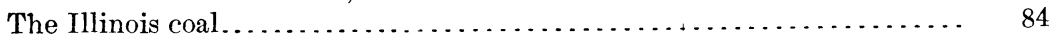

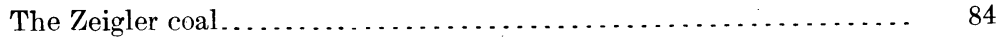

The Hart-Williams coal. . . . . . . . . . . . . . . . . . . . . . 85

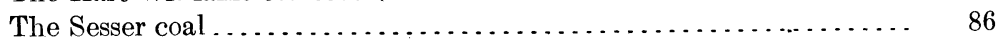

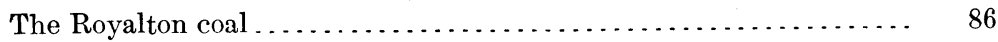

The Boxton (Iowa) coal . . . . . . . . . . . . . . . . . . . . . . 87

The Vandalia (Ind.) coal. . . . . . . . . . . . . . . . . . . . . . 89

Publications on the composition of coal . . . . . . . . . . . . . . . . . . . 291

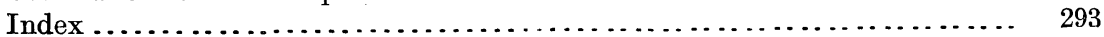




\section{ILLUSTRATIONS.}

Plate I. A, Peat bog near Kiel, Wis.; $B$, Near view of bog near

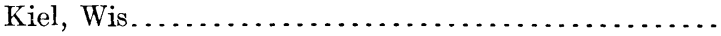

II. $A$, Near view of peat bog in Calumet County, Wis.; $B$, Near view of peat bog in Manitowoc County, Wis.; $C$, Another view of the bog in Manitowoc County, Wis...

III. $A$, Close view of the bog near Kiel, Wis.; $B$, Perpendicular view of surface of bog near Kiel, Wis.................

IV. $A$, Lump of peat, natural size; $B$, Magnified area of lump

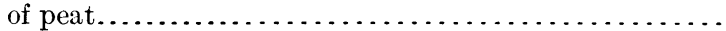

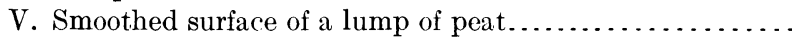

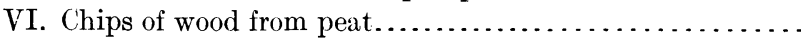

VII. $A$, Cross section of woody peat $(\times 300)$; $B$, Cross section of woody peat $(\times 1,000)$.

Page.

VIII. $A$, Organisms in woody peat $(\times 1,000) ; B$, Spores of a liv-

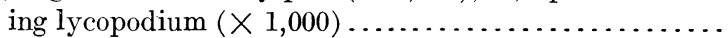

IX. $A$, Cross section of a leaf of a living cycad $(\times 100) ; B$, Cross section of a living pine needle $(\times 100) \ldots \ldots \ldots \ldots \ldots . . \ldots 3$

X. Lump of coal from Sesser, Ill..................... 104

XI. $A$, Lump of coal from Benton, Ill.; $B$, Opposite side of

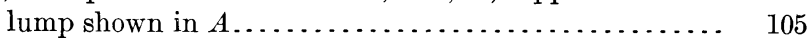

XII. Anthraxylous lump of coal from Benton, Ill........... 106

XIII. Another view of lump shown in Plate XII............. 107

XIV. Cone in coal from Benton, Ill. $(\times 10) \ldots \ldots \ldots \ldots \ldots \ldots .108$

XV. A magnified area from Plate XII $(X 10) \ldots \ldots \ldots \ldots \ldots . . . . . .6$

XVI. A magnified area from Plate XIII $(\times 10) \ldots \ldots \ldots \ldots \ldots . \quad 110$

XVII. Opaque vertical section of coal from Royalton, Ill. $(\times 10) . \quad 113$

XVIII. Continuation from Plate XVII ................... 114

XIX. Continuation from Plate XVIII..................... 115

XX. Continuation from Plate XIX ................... 116

XXI. Continuation from Plate XX ................. 117

XXII. $A$, Cross section of rodlets in coal from Royalton, Ill.; $B$, Lamination in coal from Poyalton, Ill............ 118

XXIII. Opaque cross section of coal from Zeigler, Ill........... 119

XXIV. A, Opaque cross section of thin laminæ, coal from Zeigler, Ill.; $B$, Opaque cross section of coal from Sesser, Ill . . . 120

XXV. Horizontal cleavage surface of coal from the Vandalia mine, near Terre Haute, Ind. $(\times 2) \ldots \ldots \ldots \ldots \ldots \ldots \ldots$.

XXVI. Another horizontal cleavage surface of coal from the Vandalia mine $(\times 2) \ldots \ldots \ldots \ldots \ldots \ldots \ldots \ldots \ldots \ldots \ldots \ldots \ldots \ldots$.

XXVII. Horizontal cleavage surface of coal from Benton, Ill......

XXVIII. A, Horizontal cleavage surface of coal from Benton, 11l., from lump shown in Plate XI; $B$, Another cleavage surface of lump of coal shown in Plate XI.............

XXIX. Horizontal cleavage surfaces of coal from the Hart-Williams mine..................................... 127

XXX. Horizontal cleavage surface of coal from Sesser, Ill...... 128 
XXXI. Horizontal cleavage surface of coal from Buxton, Iowa, shows general structure and appearance $(\times 5) \ldots \ldots \ldots$.

XXXII. Horizontal cleavage surface of coal from Buxton, Iowa, shows woody components $(\times 10) \ldots \ldots \ldots \ldots \ldots \ldots$.

IXXIII. Horizontal cleavage surface of coal from Buxton, Iowa, shows finely divided woody matter $(\times 10) \ldots \ldots . . .$.

XXXIV. A, Horizontal cleavage surface of coal from Zeigler, Ill.; $B$, Horizontal cleavage surface through "compact" coal of the coal from Royalton, Ill. $(\times 10) \ldots \ldots \ldots \ldots$.

XXXV. A, Horizontal cleavage surface of the coal from Royalton, Ill.; $B$, Horizontal cleavage surface of the coal from Royalton, similar to $A(\times 10) \ldots \ldots \ldots \ldots \ldots \ldots \ldots$.

Page.

XXXVI. $A$, Whole section of outcrop of Pittsburgh coal, greatly reduced; $B, \Lambda$ lump of Pittsburgh coal................

XXVII. Opaque vertical section of coal from the Oak mine, first

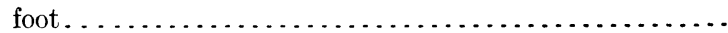

XXVIII. Opaque vertical section of coal from the Oak mine, second foot........................................

XXXIX. Opaque vertical section of coal from the Oak mine, third

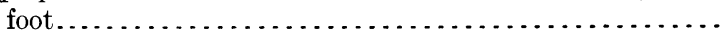

XL. Opaque vertical section of coal from the Oak mine, fourth

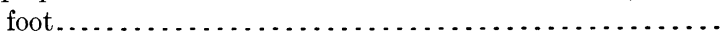

XLI. Opaque vertical section of coal from the Oak mine, fifth foot.

XLII. Opaque vertical section of coal from the Experimental mine.

XLIII. Another opaque vertical section of coal from the Experimental mine

XLIV. $A$, Thin vertical section of coal $(\times 10)$ from the Oak mine, first foot; $B$, Thin vertical section of coal $(\times 20)$ from the Oak mine, first foot.......................

XLV. $A$, Thin vertical section of coal $(\times 10)$ from the Oak mine, second foot; $B$, Thin vertical section of coal $(\times 20)$ from the Oak mine, second foot....................

XLVI. $A$, Thin vertical section of coal $(\times 10)$ from the Oak mine, third foot; $B$, Thin vertical section of coal $(\times 20)$ from the Oak mine, third foot.........................

XLVII. $A$, Thin vertical section of coal $(\times 10)$ from the Oak mine, fourth foot; $B$, Thin vertical section of coal $(\times 20)$ from the Oak mine, fourth foot........................

XLVIII. $A$, Thin vertical section of coal from the Oak mine, fifth foot $(\times 20) ; B$, Area from Plate XLIV, $A(\times 200) \ldots .$.

XLIX. $A$, Part of section shown in Plate XLIV, $A ; B$, Layer of dull coal from the same section shown in Plate XLIV, $A$.

L. $A$, Thin vertical section of $\operatorname{coal}(\times 200)$ from the Oak mine, second foot; $B$, Another thin vertical section of same coal as $A$.

LI. $A$, Thin vertical section of coal $(\times 200)$ from the Oak mine, second foot; $B$, Part of section shown above $(X 1,000)$..

LII. $A$, Thin vertical section of coal $(\times 200)$ from the Oak mine, second foot; $B$, Another cross section from same

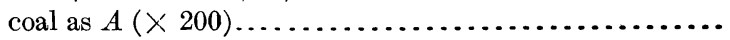


Plate LIII. $A$, Area from Plate XLIV, $A(\times 200) ; B$, Area from Plate XLIV, $A(\times 1,000)$

LIV. $A$, Thin vertical section of coal $(\times 200)$ from the Oak mine, second foot; $B$, Another thin section of coal $(\times 200)$ from the Oak mine, second foot..................

LV. $A$, Thin vertical section of coal $(\times 200)$ from the Oak mine, third foot; $B$, Another thin section from the third foot of coal, Oak mine $(\times 200) \ldots \ldots \ldots \ldots \ldots \ldots \ldots$.

LVI. $A$, Thin vertical section of coal $(\times 200)$ from the Oak mine, fourth foot; $B$, Another thin section of fourth-foot coal, Oak mine $(\times 200)$

LVII. $A$, Thin section of the same coal shown in Plate LVI, showing cell structure of anthraxylon strips $(X 200)$; $B$, A thin section of the same coal shown in Plate LVI, showing closely packed anthraxylon strips $(\times 200) \ldots$

LVIII. $A$, Thin verticai section of coal from the Oak mine, fifth foot $(\times 200) ; B$, Another section from the fifth foot of coal, Oak mine $(X 200) \ldots \ldots \ldots \ldots \ldots \ldots \ldots \ldots$.

LIX. $A$, A thin section from the same foot of coal as that shown in Plate LVIII $(\times 200) ; B$, Thin section of anthraxylon with resinous inclusions $(X 200) \ldots \ldots \ldots \ldots \ldots \ldots$.

LX. $A$, Megasporangium in coal from the Oak mine $(\times 200)$; $B$, Charccal in coal from the Oak mine $(\times 200) \ldots \ldots .$.

LXI. $A$, Thin horizontal section of coal from the Oak mine, first foot $(\times 150) ; B$, Highly magnified area from the same

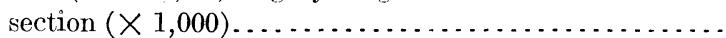

LXII. $A$, Thin horizontal section of coal from the Oak mine, second foot $(\times 150) ; B$, Area from the same section, highly magnified $(X 1,000) \ldots \ldots \ldots \ldots \ldots \ldots \ldots$.

LXIII. Thin vertical section of coal from the Experimental mine

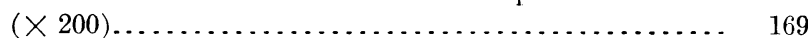

LXIV. Continuation from Plate LXIII.................... 170

LXV. Continuation from Plate LXIV ................... 173

LXVI. Continuation from Plate LXV .................... 174

LXVII. Thin vertical section of coal from Experimental mine, shows spore-exines, anthraxylon chips, and more highly carbonized matter.

LXVIII. Thin vertical section of coal from Experimental mine, shows macerated anthraxylon and well-preserved bark tissue...................................

LXIX. $A$, Thin vertical section of coal from the Experimental mine, showing strip of anthraxylon; $B$, Thin vertical section of coal from Experimental mine, shows typical

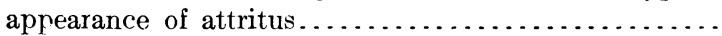

LXX. $A$, Area from sections hown in Plate LXIX, $B(\times 1,000)$; $B$, Another area from the section shown in Plate IXIX, $B(\times 1000)$.

LXXI. A, Thin horizontal section of coal from the Experimental mine, cut through humic layer and anthraxylon chip $(\times 150) ; B$, Thin horizontal section of coal from Experimental mine, cut through humic attritus............ 
Plate LXXII. A, Vascular strand embedded in attritus, coal from Experimental mine: $B$, Thin horizontal section of coal from Experimental mine, cut through two overlapping anthraxylon chips........................

LXXIII. $A$, Tissues in coal from Experimental mine; $R$, Sporangium in attritus, coal from Experimental mine.........

LXXIV. $A$, General appearance of attritus, coal from Experimental mine; $B$, Resinous particles in coal from Experimental mine $(X 200)$

LXXV. $A$, Area from section shown in Plate LXXIV, $B(\times 1,000)$; $B$, Thin horizontal section of coal from the Experimental mine, showing anthraxylon and spore-exines in attritus $(\times 1,000) \ldots \ldots \ldots \ldots \ldots \ldots \ldots \ldots \ldots \ldots \ldots \ldots \ldots \ldots$.

LXXVI. A, Thin horizontal section $(\times 1,000)$ of coal from the Experimental mine, through carbonaceous attritus; $B$, Another section $(\times 1,000)$ of coal from Experimental mine, through carbonaceous attritus.................

LXXVII. $A$, Thin vertical section of coal from Madison, Pa. $(\times 200)$; $B$, Area from near center of same section $(\times 1,000) \ldots$.

LXXVIII. $A$, Resinous and nonresinous strips of anthraxylon in Pittsburgh coal from an unknown locality $(\times 200)$; $R$, Section of Pittsburgh coal from an unknown locality.

LXXIX. $A$, Thin vertical section of coal from the Pittsburgh bed, through a laver rich in humic and in carbonaceous matter; $B$, Part of the section shown above $(\times 1,000) \ldots$

LXXX. $A$, Thin cross section of coal from the Pittsburgh bed, showing a layer rich in humic matter $(\times 200) ; B$, Part

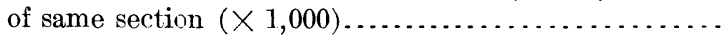

LXXXI. $A$, Another part of the section shown in Plate LXXX, $A(\times 1,000) ; B$, Thin cross section of cuticle in Pitts-

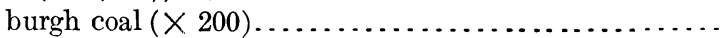

LXXXII. Spore-exines and a pollen grain from the Pittsburgh coal.

LXXXIII. Thin vertical section of Pittsburgh coal, showing barklike tissues.

LXXXIV. Thin vertical section of coal from Carbon Hill, Ala. $(\times 200)$.

LXXXV. Thin section of coal from Carbon Hill, Ala., showing an

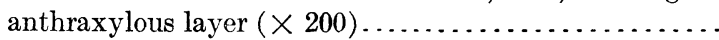

LXXXVI. Thin vertical section of coal from Carbon Hill, Ala., showing a layer of humic attritus $(\times 200) \ldots \ldots \ldots \ldots \ldots$.

LXXXVII. Thin vertical section of coal from Carbon Hill, Ala., showing character of anthraxylon components $(\times 200) \ldots \ldots$.

LXXXVIII. $A$, Typical cross section of attritus of coal from Carbon. Hill, Ala. $(\times 200) ; B$, Part of the same section $(\times 1,000)$.

LXXXIX. $A$, Thin vertical section of coal from the Hart-Williams mine; $B$, Part of the same section $(\times 1,000) \ldots \ldots \ldots$.

XC. $A$, Part of a thin vertical section of coal from the HartWilliams mine $(\times 1,000) ; B$, Another part of the same section $(X 1,000) \ldots \ldots \ldots \ldots \ldots \ldots \ldots \ldots \ldots \ldots \ldots$.

XCI. $A$, Thin vertical section of one of the larger anthraxylon components in coal from the Hart-Williams mine, Benton, Ill.; $B$, Thin vertical section of coal from the Benton mine, Benton, Ill., showing general appearance.......

XCII. $A$, Thin vertical section of coal from Zeigler, Ill.; $B$, Typical cross section of the Zeigler coal............. 
Plate XCIII. $A$, Thin vertical section of Zeigler coal, showing strips of anthraxylon; $B$, Thin vertical section of Zeigler coal, showing anthraxylon structure...................

XCIV. $A$, Thin vertical section of coal from Zeigler, Ill., showing typical lamination; $B$, Thin vertical section of Zeigler coal showing general character of certain laminæ.......

XCV. $A$, Part of the section shown in Plate XCIV, $B$, from the middle of level $1-\mathrm{D}(\times 1,000) ; B$, Part of the section shown in Plate XCIV, $B$, from the level $6-\mathrm{D}(\times 1,000)$.

XCVI. $A$, Part of an area just outside the section shown in Plate $\mathrm{XCIV}, B,(\times 1,000) ; B$, Part of the same area $(\times 1,000)$.

XCVII. $A$, Thin vertical layer of Zeigler coal, representing a layer humic attritus; $B$, Part of the lamina $3-\mathrm{D}$, shown above

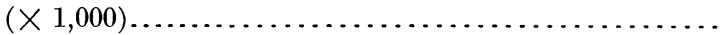

XCVIII. $A$, Thin vertical section of a layer of an Illinois coal, showing cuticles and other degradation products of leaves; $B$, Section of a similar layer showing pairs of cuticles closely united.

Page.

207

XCIX. $A$, Thin horizontal section showing general appearance of the Zeigler coal $(\times 150) ; B$, Another thin section of the Zeigler coal, shows anthraxylon matter...............

C. $A$, Thin vertical section of the coal from Sesser, Ill.; $B$, Part of the same section $(\times 200) \ldots \ldots \ldots \ldots \ldots \ldots \ldots$.

CI. $A$, Thin cross section of the "bright coal" shown in Plate XXIV, $B ; B$, Part of the section shown in CI, $A(\times 1,000)$.

CII. $A$, Another part of the section shown in Plate CI, $A(\mathrm{X}$ $1,000) ; B$, Thin vertical section of anthraxylon $(\times 200)$.

CIII. $A$, Thin vertical section of anthraxylous material in coal from Sesser, Ill. $(\times 200)$; $B$, Section of Sesser coal showing resinous-appearing particles $(X 200) \ldots \ldots \ldots \ldots . .$.

CIV. $A$, Thin cross section of Sesser coal, showing coarseness of humic matter $(X 200) ; B$, Part of section shown above

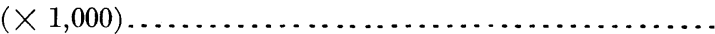

CV. $A$, Thin cross section of the Sesser coal, showing appearance of spore-exines $(\times 1,000) ; B$, Thin cross section of the Zeigler coal, showing spore-exines $(X 1,000) \ldots \ldots$.

CVI. $A$, Thin cross section of coal from Royalton, Ill. $(\times 10)$; $B$, Part of the same section $(\times 200) \ldots \ldots \ldots \ldots \ldots \ldots$.

CVII. $A$, Thin cross section of the "bright coal" or anthraxylon of the Royalton coal $(\times 200) ; B$, Cross section of another anthraxylon component of the Royalton coal $(\times 200) \ldots$

CVIII. $A$, Thin vertical section through the "dull coal" of the Royalton coal $(\times 200) ; B$, Part of the same section

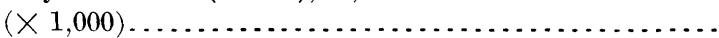

CIX. A, Another typical cross section of the "dull coal" in Royalton coal $(\times 200) ; B$, Part of the same section

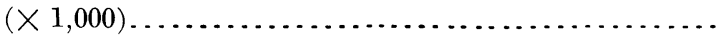

CX. $A$, Thin vertical section of the Royalton coal, showing similarity with Zeigler coal $(\times 200) ; B$, Part of the same section $(\times 1,000)$

CXI. $A$, Spore-exine from the coal from Zeigler, Ill. $(\times 1,000)$; $B$, Spore-exine from the coal from the Hart-Williams mine, near Benton, Ill. $(\times 1,000) \ldots \ldots \ldots \ldots \ldots \ldots$.

CXII. Spore-exines at high magnification..................... 
Plate CXIII. $A$, Cuticle from the Illinois coal $(\times 100) ; B$, Spore-exine in coal from Shelbyville, Ill. $(\times 1,000) \ldots \ldots \ldots \ldots \ldots$. CXIV. $A$, Thin vertical section of coal from Shelbyville, Ill. $(\times 200) ; B$, Part of same section $(\times 1,000) \ldots \ldots \ldots \ldots$.

CXV. $A$, Thin vertical section showing general appearance of the "dull coal" in coal from Shelbyville, Ill.; $B$, Part of same section $(\times 1,000) \ldots \ldots \ldots \ldots \ldots \ldots \ldots \ldots \ldots \ldots$.

CXVI. $A$, Another typical cross section of the Shelbyville coal $(\times 200) ; B$, Part of the same section $(\times 1,000) \ldots \ldots \ldots$.

CXVII. Spore-exines from the coal from Shelbyville, Ill........... CXVIII. A, Megaspore-exine in the coal from Shelbyville, Ill. $(\times 35) ; B$, Some of the smaller megaspore-exines in the Shelbyville coal $(X 35) \ldots \ldots \ldots \ldots \ldots \ldots \ldots \ldots \ldots$.

CXIX. $A$, Three megaspore-exines isolated from coal from Shelbyville, Ill. $(\times 35)$; $B$, Cross section of coal.from Shelbyville, Ill., showing megaspore-exines in situ $(\times 35) \ldots$

CXX. Leaf tissues in coal from Shelbyville, Ill................

CXXI. $A$, Thin vertical sectlon of the coal from Buxton, Iowa $(\times 10) ; B$, Vertical section of the same piece of coal $(\times 10)$.

CXXII. $A$, Thick vertical section of coal from Buxton, Iowa, low magnification; $B$, Horizontal cleavage suriace of coal from Buxton, Iowa ..............................

CXXIII. Horizontal cleavage surface of anthraxylon $(X 5) \ldots \ldots$. CXXIV. A, Thin vertical section of the coal from Buxton, Iowa, showing general appearance at high magnification $(\times 200) ; B$, Thin vertical section, typical of the Buxton

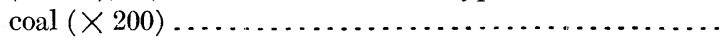

CXXV. $A$, Thin vertical section of the coal from Buxton, Iowa, showing appearance of resinous-carbonaceous attritus; $B$, Thin vertical section of the coal from Buxton, Iowa, showing characteristic laminations..................

CXXVI. $A$, Thin vertical section of the coal from Buxton, Iowa, showing irregular anthraxylon laminations $(\times 200)$; $B$, Thin vertical section of the coal from Buxton, Iowa, showing resinous sheets and pyrite granules $(\times 200) \ldots$

CXXVII. $A$, Thin vertical section of coal from Buxton, Iowa, showing spore-exines and earthy and carbonaceous matter; $B$, Part of same section $(\times 1,000) \ldots \ldots \ldots \ldots$.

CXXVIII. $A$, Thin horizontal section of coal from Buxton, Iowa, representing mostly anthraxylon $(\times 200) ; B$, Thin horizontal section of the coal from Buxton, Iowa, showing humic matter and attritus $(\times 200) \ldots \ldots \ldots \ldots \ldots$

CXXIX. $A$, Thin horizontal section of the Buxton coal, showing attritus; $B$, Part of the same section $(\times 1,000) \ldots \ldots \ldots$.

CXXX. A, Megaspore-exines isolated from coal from Buxton, Iowa $(\times 35) ; B$, Another group of megaspore-exines ( $\times 35)$..

CXXXI. Cross sections of megaspores in coal from Buxton, Iowa

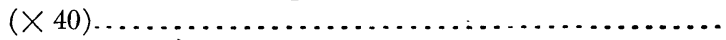

CXXXII. Spore-exines in coal from Buxton, Iowa...............

CXXXIII. A, Part of a sporangium in the coal from Buxton, Iowa $(\times 200) ; B$, Another part of the same sporangium $(\times 200)$.

CXXXIV. $A$, Wall of sporangium shown in Plate CXXXIII $(\times 1,000)$; $B$, Spore-exine mass in the sporangium wall shown above

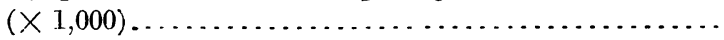


Plate CXXXV. Spores partly covered with ramenta, in the Illinois coals.

CXXXVI. Spore-exines, pollen grain, and cuticle in coal from Bux-

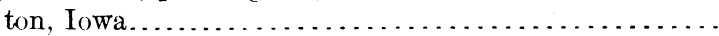

CXXXVII. $A$, Thin vertical section of coal from the Sipsey mine, Ala., at low magnification $(\times 10) ; B$, Thin vertical section of coal from the Sipsey mine, showing attritus $(X 200) \ldots$

CXXXVIII. $A$, Thin vertical section of the coal from the Sipsey mine, showing anthraxylon and "dull coal" layers ( $X 200)$; $B$, Thin vertical section of the coal from the Sipsey mine, showing spore-exines and anthraxylon $(X 200) \ldots \ldots$.

CXXXIX. $A$, Part of the section shown in Plate CXXXVIII, $B$ $(X 1,000) ; B$, Another part of the section shown in Plate CXXXVIII, $B(\times 1,000) \ldots \ldots \ldots \ldots \ldots \ldots \ldots$

CXL. $A$, Cell tissue in coal from the Sipsey mine $(\times 200) ; B$, Part of the same section $(X 1,000)$

CXLI. $A$, Thin horizontal section of the coal from the Sipsey mine; $B$, Spore-exine from the Sipsey coal $(\times 1,000) \ldots \ldots \ldots$

CXLII. Vertical fracture of the coal from the Vandalia mine, near Terre Haute, Ind. $(\times 2) \ldots \ldots \ldots \ldots \ldots \ldots \ldots \ldots$

CXLIII. $A$, Thin vertical section of coal from the Vandalia mine, at low magnification; $B$, Another vertical section of the Vandalia coal at low magnification.

CXLIV. $A$, Thin horizontal section of the Vandalia coal, at low magnification; $B$, Another horizontal section of the Vandalia coal at low magnification.................

CXLV. $A$, Thin horizontal section of Vandalia coal, cut obliquely through layer of attritus $(\times 150) ; B$, Oblique section through strip of anthraxylon $(X 150) \ldots \ldots \ldots \ldots \ldots$.

CXLVI. $A$, Thin vertical section of coal from the Vandalia mine, showing various components $(\times 200) ; B$, Another thin vertical section of the coal from the Vandalia mine, showing various components $(\times 200) \ldots \ldots \ldots \ldots \ldots$.

CXLVII. $A$, Thin vertical section of coal from the Vandalia mine, showing much resinous matter $(\times 200) ; B$, Another thin vertical section of the coal from the Vandalia mine, showing resinous layers $(X 200) \ldots \ldots \ldots \ldots \ldots \ldots$

CXLVIII. $A$, Thin vertical section of coal from the Vandalia mine, showing anthraxylon, mixed attritus, and resinous layer $(\times 200) ; B$, Thin vertical section of the Vandalia coal, showing layers of different constituents $(\times 200) \ldots \ldots$.

CXI.IX. A, The first of a series of three sections of Vandalia coal, repı asenting resinous anthraxylon in various stages of decay; $B$, Second section of the series $(\times 200) \ldots \ldots \ldots$.

CL. A. Third section of the series, showing decay of resinous anthraxylon $(\times 200) ; B$, Thin vertical section of the Vandalia coal, very highly magnified $(X 1,000) \ldots \ldots .$.

CLI. $A$, Cross section of the stem of a fossil medullosa $(X 5)$; $B$, Longitudinal section of inner cortex $(\times 10) \ldots \ldots$.

CLII. Longitudinal section of a stele and the inner cortex shown

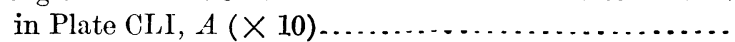

CLIII. Longitudinal section of inner and outer cortex shown in Plate CLI, $A(\times 10) \ldots \ldots \ldots \ldots \ldots \ldots \ldots \ldots . . . . .$. 
Puate CLIV. $A$, Medullosa-like structure in coal from Shelbyville, Ill. $(\times 10) ; B$, Another horizontal fracture in Shelbyville coal, showing medullosa-like structure $(X 10) \ldots \ldots \ldots .284$

CLV. Medullosa-like structure in coal from Zeigler, Ill. $(X 5) \ldots \quad 285$

CLVI. Rodlets in coal from Royalton, Ill. $(\times 25) \ldots \ldots \ldots \ldots \ldots .286$

CLVII. $A$, Fungal hyphae in coal from Vandalia. Ill $(\times 1,000)$; $B$, Another section showing fungal hyphae in coal from

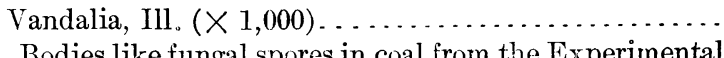

CLVIII. $A$, Bodies like fungal spores in coal from the Experimental mine $(\times 150) ; B$, Part of same section $(\times 1,000) \ldots \ldots 288$

CLIX. $A$, Another area from the section shown in Plate CLVIII, $A(\times 1,000) ; B, A$ third area from the section shown in Plate CLVIII, $A(\times 1,000) \ldots \ldots \ldots \ldots \ldots \ldots \ldots$.

CLX. $A$, A section of coal from the Experimental mine, showing unknown organisms $(\times 1,000) ; B$, Another view of unknown organisms in coal from the Experimental

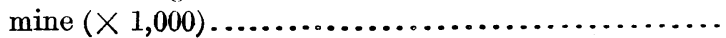





\title{
STRUCTURE IN PALEOZOIC BITUMINOUS COALS.
}

\author{
By Reinhardt Thiessen.
}

\section{INTRODUCTION.}

Views and conceptions of the origin, composition, and general nature of coal differ so widely that to determine the real extent of actual knowledge is no easy matter. The chemist finds difficulty in attacking the chemical problems and the engineer lacks a broad chemical basis for the study of his problems. Thus the economical and efficient utilization of coal in the industries suffers from a lack of knowledge of the composition of coal itself.

Most scientists interested in this matter, as has been brought out in discussions during the recent investigation of coal problems, appear to have only a vague idea of the components of coal and their origin. Some are even in doubt as to whether substances derived from the wood and resins of plants form a part of coal; and few seem to have more than the dimmest idea of what are the components of coal, the condition in which these now exist, and the transformations that they have undergone.

Although during the past century or more many correct observations have been made and recorded, these were falsely or inadequately interpreted, so that many of the interpretations rendered are contradictory. As a result there has been great confusion. Many of the observations made in the past, although accurate and correct, could not be explained, because the principles involved in a correct solution of the problem were not then known. For example, Parkinson, Hutton, Petzhold, Guembel, and others made valuable discoveries regarding the processes by which plant substances are transformed into coal, but as the principles involved are those of colloidal chemistry, a science not known to the scientific world of that time, the observed facts could not be interpreted and the solution of the whole problem was blocked. The explanation of the true meaning of the alternating bright and dull bands so familiar in all ordinary bituminous coals affords another example. This banding has been observed and recorded from the earliest times, and has led to the forming of many false theories. Some geologists, for example, have endeavored to explain the bands as due to alternating climatic conditions during the coal-forming period. Had the 
geologists known the true nature of coal they could not have made this mistake nor many others made in the past.

To fill in a few of these gaps and to clarify some of the existing confusion is the aim of this paper.

The immediate cause that led the author to investigate further the composition of coal and the origin and structure of its constituents was that when an attempt was made to discover the meaning of the coking and noncoking properties of coal a more exact knowledge of the nature of coal was required than was then available.

\section{THE COALS STUDIED.}

The coals that formed the basis of the study described in this bulletin were selected from the following localities: From the Pittsburgh bed at the Oak mine, a short distance south of Pittsburgh, Pa., at the experimental mine of the Bureau of Mines near Bruceton, Pa., at the Keystone mine, Madison, Pa., and several samples from unknown places collected in Pittsburgh from coal for domestic purposes; from the Jagger bed, at the No. 11 mine of the Galloway Coal Co., Carbon Hill, Walker County, Ala.; from the Black Creek bed at the Sipsey mine, Maryland Coal \& Coke Co., Sipsey, Walker County, Ala.; from Consolidated Coal Co. mine No. 18, Buxton, Monroe County, Iowa; from Bed No. 5, at the No. 82 mine of the Vandalia Coal Co., near Terre Haute, Vigo County, Ind.; from Bed No. 6 (Herrin coal), at the mine of the Hart-Williams Coal Co., near Benton, the mine of the Benton Coal Co. near Benton, the Zeigler mine of the Bell and Zoller Coal Co. at Zeigler, the north mine of the Franklin Coal \& Coke Co., at Royalton, and a mine near Sesser, these five mines all in Franklin County, Ill.; and from Bed No. 14 in the "barren measures," McLeansboro formation, rear Shelbyville, Shelby County, Ill. Comparisons were made with coals from other localities and other parts of the world, as from China, Japan, New South Wales, and England.

The coal samples were collected according to the standard method of sampling, except the coals from the Oak mine in the Pittsburgh bed, where a series at intervals of a foot were collected, the coal from the Royalton mine, samples of which were collected from near the top, the middle, and just below the carbonaceous shale band, and the samples from the Buxton mine, which were collected in a series from top to bottom.

\section{HISTORICAL REVIEW.}

\section{THE WOODY STRUCTURE IN COAL, AND THE MEANING OF THE ALTERNATING DULL AND BRIGHT LAMIN\&.}

The knowledge of the woody structure in coal has been obtained largely from fractures horizontal to the bedding planes, and to some 
extent from the so-called impressions, but mainly from the charcoal present in almost every coal. Very little structure seems to have been observed in the compact coal; what was at one time supposed to be the structure of wood later proved to be not that of wood at all but thin flat strips derived from woody tissues. The latest verdict even goes so far as to say that no woody structure has been preserved in coal except in the charcoal.

Since the earliest investigations all ordinary coals were known to contain compact coal and charcoal, also called "mother of coal," compact coal forming by far the larger proportion. The compact coal in turn is composed of two kinds, a bright and a dull coal. The dull coal has been called by various authors, " dull coal," " matt coal," "canelloid coal," and "sapanthrakon," while the bright bands have been called, "bright coal," "glanz coal," "humus coal," "jet coal," "carbohumin," and "hydrocarbon." But the true significance of these two kinds has never been definitely explained. In order to discuss clearly the alternating bright and dull bands and the woody structure, the results and interpretations of investigations since the time that a minute examination of coal was begun are briefly recounted.

HENRY WITHAM, 1831-1832.

Witham, ${ }^{a}$ who was the first to make thin coal sections, saw and illustrated a confused cellular tissue that seemed to him to be that of vascular plants. As he found and illustrated the same bodies in a cannel coal, evidently they were not cell structures of vascular plants, but cross sections of spores. Hutton, ${ }^{b}$ who examined coals from Newcastle and the surrounding territories in England, thought that the ordinary splint or slate coal was composed of cannel coal and coking coal arranged in thin alternating layers because of the remarkable bodies seen in the sections made by Witham. The layers of cannel coal he found to be composed largely of light wine-colored cells, and few of them could be found in the layers of the coking coal. In the best portions of the coal, the "most homogeneous and the most crystalline" parts in which the plant texture had been obliterated entirely, these cells could not be found at all. The coking coal was the best and the

$a$ Witham, Henry, On the general results of botanical investigation concerning the character of the ancient flora which by its composition has furnished the material of coal seams: Rept. 1st and 2d meetings British Ass'n Adv. Sci., 1831 and 1832, p. 78; On fossil vegetation: Rept. 1st and 2d meetings British Ass'n Adv. Sci., 1831 and 1832, p. 578. Bennie, James, and Kidston, Robert, On the occurrence of spores in the Carboniferous formation of Scotland; Proc. Roy. 1'hys. Soc. Edinburgh, vol. 9, 1885-1888, pp. 82-117.

${ }^{b}$ Hutton, W., Observations on coal. London and Edinburgh Mag. and Jour. of Science, vol. 2, 1883, pp. 302-304.

$125536^{\circ}-20-$ Bull. $117-2$ 
largest proportion of the coal. In all of the varieties of coals he observed some plant structure. It is quite evident from what is now known of coal, that the layers called coking coal by Hutton were the anthraxylon components, and the layers of cannel coals were the attritus in which the anthraxylon components were embedded, exactly as in the coals of this country.

FRIEDERICK LINK, 1838.

Link ${ }^{a}$ could not find any woody structure in the coals except in the charcoal, or mother of coal. He believes that what Hutton saw was not the structure of wood but something else, otherwise he would have spoken of wood fibers and not confined himself entirely to cells.

\section{H. R. GÖPPERT, 1840-1848.}

All the observations and identifications of plants made in the list of Göppert's ${ }^{b}$ memorable study was of horizontal cleavage fracture, and particularly of the charcoal. He almost always speaks of impressions, and mentions the stems, "or, more properly, their barks," lying flat one upon another without the inner parenchyma. The latter sometimes was preserved also and converted into coal-often so well preserved that the cells could still be recognized under the microscope. As Göppert never mentioned thin sections his microscopic examinations were presumably of small fragments of coal, and most likely of the horizontal faces of very thin chips or splinters that he frequently mentions.

\section{JOHN QUECKETT, 1853.}

Queckett, ${ }^{c}$ in comparing cannel coal with the Torbane Hill mineral, points out the woody structure in cannel coal in which cells and fibers may be recognized distinctly. But from his illustrations. which probably are very good representations of what he saw, his "cells" were cross-sections of spores and his "fibers" were thin layers of woody coal or the anthraxylon components.

${ }^{a}$ Link, Friederick, Ueber den Ursprung der Steinkohlen und Braunkohlen nach mikroskopischen Untersuchungen : Abhandl. K. Akad. Wiss. Berlin, 1838, pp. 33-44.

${ }^{b}$ Göpperi, H. R., ̈̈ber die Verbreitung der fossilen Gewäichse in der Steinkohlenformation: Schlesische Gesell. Übersicht, 1840, pp. 74-77; Über die Holzarten in den braunkohlenartigen Ablagerungen: Kartstens Archiv., Bd. 18, 1844, pp. 527-529; Uber das verhältniss der Boghead Parrot Cannelcoal zur Steinkohle: Dingl. poly. Jour., Bd. 145, 1857, pp. 212-217; Abhandlung, eingesandt als Antwort auf die Preisfrage_-" Man suche durch genaue Untersuchungen darzuthun, ob die Steinkohlenlager aus Pflanzen entstanden sein, welche an den Stellen, wo jene gefunden werden, wuchsen; oder ob diese Pflanzen an anderen Orten lebten, und nach den Stellen, wo sich die Steinkohlenlager befinden hingefürt wurden": Nat. Verh. Monatschr., Bd., 4, 1848, pp. 1-298.

c Queckett, John, On the minute structure of a peculiar combustible mineral from the coal measures of Torbane Hill, near Bathgate, Linlithgowshire, known in commerce as Boghead cannel coal: Trans. Micros. Soc. London, vol. 2, 1853, pp. 34-66. 
JOHN BALFOUR, 1854.

Balfour ${ }^{a}$ calls attention to the same error, and calls these same objects "spaces and cavities."

\section{J. W. DAWSON, 1859-1866.}

Dawson ${ }^{b}$ appears to be the first to recognize that coal is composed of compact coal and mineral charcoal, and that the compact coal, by far the larger proportion of the mass, "consists of lustrous concoidal cherry (or pitch coal), or of less lustrous slate coal with flat fracture, or of coal containing much earthy matter arranged in thin interrupted laminæ. The vegetable matter to which it owes its origin has been transformed, through a process of subaqueous bituminous putrefaction, into a nearly homogeneous mass in which traces of structure and of flattened plants composing it are still recognizable. Dawson's studies convinced him that the "bright coal " had its origin in the barks of Sigillaria and allied plants, the "dull coal" came from herbaceous plants and molds, and the wood and bark tissues yielded mineral charcoal.

On a close analysis he found that the layers or laminæ of the cherry coal or pitch coal and those of the finer varieties of slate coal showed on the surfaces outlines of flattened trunks, but that the laminæ of the coarse coal seemed to consist of numerous sublaminæ of disintegrated vegetable matter mixed with mud. Evidently he viewed the coal on the surfaces only and not through thin sections, although he used thin sections. The difficulty probably was that his sections were not thin enough to permit him to recognize the cell structure.

THOMAS H. HUXLEY, 1870.

Huxley ${ }^{c}$ saw wood structure in the charcoal only and none in the coal proper, which, he observes, constituted the larger proportion of all bituminous coal, and was chiefly composed of "saccular" matter. Occasionally he observed remnants of bark, but he believed the wood of the plants had decayed, and that none of it was left; the woody structures observed, except in the charcoal, were only the imprints of stems.

W. C. WILLIAMSON, 1881.

Williamson, ${ }^{d}$ like Huxley and Dawson, recognized two kinds of coal-charcoal, and the more bituminous, or compact coal. Woody

a Balfour, J. H., On certain vegetable organisms found in coal from Fordel : Trans. Roy. Soc. Edinburgh, vol. 21, 1854, pp. 187-193.

${ }^{b}$ Dawson, J. W., On the vegetable structure in coal: Quart. Jour. Geol. Soc. London, rol. 15,1859 , pp. $626-641$; on the condition of the deposition of coal, more especially as illustrated by the coal formation of Nova Scotia and New Brunswick: Quart. Jour. Geol. Soc. London, vol. 22, 1866, pp. 95-169.

$c$ Huxley, 'T. H., On the formation of coal: Contemporary Review, vol. 15, 1870, pp. 618-628.

${ }^{a}$ Williamson, W. C., Preliminary remarks on the microscopic structure of coal: Rep. British Ass'n. Adv. Sci., 1881, pp. 625-626. 
structure he observed in the charcoal only. The compact coal he concluded to be of an entirely different nature, and to consist of two components- $(a)$ spores embedded in $(b)$ a general matrix that he calls a brown plasm; the origin of this plasm he believed to be decayed regetation, but he left the question open.

\section{G. W. VON GUEMBEL, 1883.}

Von Guembel ${ }^{a}$ is generally conceded to have furnished the most comprehensive and the most reliable account of the structure of coal. $\mathrm{U}_{\mathrm{p}}$ to his time the knowledge of coal was mainly obtained through the study of its cleavage surfaces, which have been interpreted correctly by few investigators. Thin sections were difficult to make, and the appliances needed for observing them were inadequate. Guembel fortunately adapted a process employing a maceration reagent which was used by Schulze $^{b}$ to purify cellulose, and later was used in the endeavor to determine cellulose in coal. By means of this reagent Guembel macerated the coals to rarious degrees, and watched the process of dissolution under the microscope, and in that way he procured more accurate information concerning coal than anyone had obtained before. He was a careful and conscientious investigator and gave his results to the public only when he was sure of his ground, or, at the most, he gave suggestions as to the possible conclusions, and in that way he presented the probability of important facts, the evidence for which he believed to be inconclusive.

Guembel agrees with the general observation, so strongly emphasized by Mück and Grand 'Eury at the time, that coal is composed mainly of thin layers of alternating "glanz" and "dull coal," often with interlayers of charcoal in the form of scattered débris or of solid masses or strips. He thought that only a very few coal beds consisted predominantly of either "dull coal" or of "glanz coal," and that the main mass in some beds was formed of charcoal.

The "glanz" or "bright coal" he describes as consisting on the whole of an intensive brown mass, apparently without structure when seen in thin chips. When treated with the macerating reagent it revealed only very small traces of plant structure, but he recognized various plant tissues in it when he further treated it with alcohol and ammonia, or when he heated it with the macerating reagent. Parenchymatous cells, such as occur in the bark, were chiefly observed, also tissues similar to those of wood, parts of leaves revealed through the presence of cuticles, and circular, cuticular disks or spherical bodies, usually called spores. He rarely failed

a Von Guembel, C. W., Beiträge zur Kenntniss der Textur verhältnisse der Mineralkohlen: K.-b. Akad. Wiss. Munich, Sitzungsber. math.-phys. Klasse, Bd. 13, 1883, pp. 111-216.

b Schulze, Franz, Ueber das Vorkommen wohlerhaltenes Cellulose in Braunkohle und Steinkohle: Sitzungsber. K. preuss. Akad. Wiss. Berlin, 1855, pp. 676-678. 
to recognize abundant plant structure, yet he says that he did not succeed in obtaining complete eviclence that the whole mass of coal included distinguishable plant structures. He was almost convinced that often the plant substances have been so uniformly transformed into "glanz coal" that the difference between the tissues and the fillings of the interstices with "carbohumin" may be distinguished only through very careful treatment. He had, no doubt, according to observations made on dopplerite, perceived that true structureless substances form part of certain coal deposits.

The "dull coal" appeared to him to be composed almost entirely of fibrous cells, such as those from leaves of grasses, with parenchymatous tissue a few spores, and a few scalariform vessels.

\section{EDWARD WETHERED, 1885.}

Wethered ${ }^{a}$ also distinguished in the compact coal two kinds-a bright and a dull, alternating with each other. He found the "dull coal" contained numerous spores but the "bright coal" few or none. The "bright coal" consisted of a structureless dark-brown mass, which he believed was mainly composed of "hydrocarbon" and a very important component of coal. The so-called bituminous coals contained more of it than the others.

\section{H. POTONIÉ, 1906-1910.}

Potonie $^{b}$ distinguishes as regards origin and formation three kinds of coal: Sapropellic, humus, and liptobiolithic. The sapropellic coals are formed from true aquatic organisms, both plants and animals, through a process of putrefaction under exclusion of oxygen. When these are of Paleozoic age he calls them sapanthrakon and regards them as equivalent to the cannel coals. On account of their dull appearance he also calls them matt coals. The humus coals are formed primarily through a process of decay under partial exclusion of oxygen from true land plants preferring moist conditions. Under the microscope the humus coals show components derived from higher land plants and embedded in a flocculent, homogeneous groundmass. On account of their lustrous nature they are also called glanz coals. Liptobiolithic coals have been formed from land plants rich in resin, resin-waxes or waxes, which, on account of their resistant nature, were left behind when most of the cellulosic matter decayed.

${ }^{a}$ Wethered, Eaward, On the structure and origin of carboniferous coal seams: Trans. Roy. Micros. Soc., vol. 5, 1885, pp. 406-410.

${ }^{b}$ Potonie, H., Klassification und Terminologie der regenten brennbaren Biolithe and ihre Lagerstätten: Abhandl. K. geol. Landesantalt, Bd. 48, 1906 ; Die Enstehung der Steinkohle, und der Kanstobiolithe überhaupt, wie des Torfes, der Braunkohle, des Petroleums, u. s. w., 1910. 
As all laminated coals are composed of alternating sheets of "matt coal" and "glanz coal," Potonie conceived them to be composed of alternating layers of sapropellic coals (matt coal.cannel coal) and humic coals (glanz coal), and the phenomenon to have been brought about under changing conditions during coal-forming periods; that is, during certain times, when the water was high, sapropellic (cannel coal) forming conditions prevailed, and at other times, when the water was relatively low, peat or humus was formed under merely moist conditions. Such conditions might alternate many times during the deposition of a coal seam. There was, so to speak, a struggle between high water and moist or swampy conditions, and a laminated coal was the result.

Potonié considered only the larger anthraxylon components alternating with the débris as they appear to do in small pieces of coal, but evidently he did not analyze the debris so as to become aware that it is also composed of alternating sheets of " matt coal" or the attritus, and "glanz coal." He thought that the layers of "glanz" or humus coals were composed of a general degradation of land plants and were in a homogeneous condition, similar to Wethered's " carbohydrate," and that they did not consist of separate and individual components that had been at one time pieces of stems or wood; that is, pieces of anthraxylon merely embedded in a débris', or general degradation of plants contemporaneously formed.

JAMES LOMAX, 1912.

Lomax, ${ }^{a}$ after examining a series of coals, finds that they are not homogeneous, but contain well-defined structures, and most of them are decidedly laminated, consisting of alternating bands of bright and dull coals. The dull laminæ are composed of numerous.megaspores embedded in a groundmass composed chiefly of microspores; the brighter laminæ are composed of microspores in a groundmass of the remains of leaves and other plant tissues highly compressed. Some coals have less spore matter and more bands with compressed leafy residue, with here and there woody tissues inclosed, often in the form of mother of coal; but the real nature of the bright coal he does not perceive. Lomax concludes that coals do not "contain so great a quantity of material derived from the vascular or woody parts of plants, such as stems and branches, etc., as some recent authors have led one to believe. In fact, there is little evidence that any great quantity of wood enters into their composition, and what there is occurs in the form of charcoal or mother of coal."

The coals examined, except those of the Trencherbone, cannel, and Silkstone Tops, he calls purely humic coals, mainly composed of

a Lomax, James, The microscopic examination of coal and its use in determining the inflammable constituents present therein: Trans. Inst. Min. Eng., vol. 42, 1912, pp. 2-21. 
the droppings of trees and plants in the form of spores, fruits, leaves, twigs, and sometimes fragments of stems. The material in the brighest and hardest ones, he thinks, had been reduced to a pulpy state before carbonization.

\section{SAIMUEL GLOVER, 1912.}

Glover, ${ }^{a}$ who worked on Lomax's preparations, largely shares the views of Lomax. He observes a conspicuous absence of cellulosic or "actual vegetable" matter such as tree trunks, branches, twigs, and other woody tissues. The only remains of trunks found are those of erect stumps running upward through the coal seam, with occasional branches and pieces of bark near the top of the deposit. He concludes that the English coals investigated are the accumulations of leaf-moulds of a very luxuriant and dense vegetation.

\section{DAVID WHITE AND REINHARDT THIESSEN, 1914.}

White and Thiessen ${ }^{b}$ seemingly were the first to interpret the alternating bright and dull laminæe in the few bituminous coals so far examined. They concur in the old-time observation that coal is composed of alternating bright and dull layers, but they go a step further by asserting that the dull layers are further sublaminated into "bright" and "dull" laminæ, the sublaminæ often being of microscopic thickness. The bright lanninae represent components that were at one time parts of trunks of trees, stems, twigs, and branches, now much flattened and coalified. The dull laminæ are derived from more or less finely divided plant substances; the débris corresponds. in every respect to the fine black matter, or fine mud in peat, and forms the groundmass in which the woody components are invariably embedded.

EDWARD C. JEFFREY, 1914-1915.

Jeffrey ${ }^{c}$ also concurs with the general observation in recognizing three kinds of coals; charcoal, lignitoid (bright coal, glanz coal) and canneloid (dull coal, matt coal). In the ordinary bituminous coals these three kinds occur in alternating layers. Plant structure has survived only in the charcoal. The canneloid bands of the bituminous coals consist of a dark ground substance like that of the ordinary cannel coals, in which are embedded the remains of flattened spores. The "lignitoid" laminæe consist of highly modified wood, and are homogeneous, having entirely lost their original structure.

a Glover, Samuel, Notes introductory to the study of coal sections under the microscope: Jour. Gaslighting, etc., vol. 20.1912, pp. 737-739.

${ }^{b}$ White, David, and Thiessen, Reinhardt, Origin of coal, Bull. 38, Bureau of Mines, 1914,390 pp.

$c$ Jeffrey, Edward C., On the composition and qualities of coal. Econ. Geol., vol 9 1914, pp. 730-742; The mode of origin of coal: Jour. Geol., vol. 23, 1915, pp. 218-270. 
Of the 200 coals or more examined from the United States and many other coals from all over the world, Jeffrey finds none that show woody structure except in the charcoal. Although he concurs with the view that the bright laminæ in coal are derived from the woody parts of plants, he seems to have found no proof for this statement, and does not show the real nature of the laminæ.

\section{GEORGE HICKIING, 1917.}

Hickling ${ }^{a}$ agrees with White and Thiessen in the interpretation of the "bright coal" and the "dull coal," in his paper on the micropetrology of coal. But he differs regarding the origin of certain essential components of coal, the relationship between the plant tissues, whose forms are visible under the microscope, and the actual coal substances that now composes the visible structures. He believes it presumptuous to assume that the substance, as well as the form, of the plant, is under observation, and presumptuous to believe that the portion of the coal in question represents the actual material of the original plant in a more or less altered condition. In regard to contents or "fillings" of some of the cells in some remaining fragments of tissues, Hickling believes that the substance filling these cells can have no connection with any substance that may have been present in the living cell itself. He believes that the plant fragments became saturated with liquid decomposition products of other vegetation, that they osmotically reached their present condition, and that subsequent physicochemical changes have solidified them. The cell walls themselves have doubtlessly been impregnated with the same material if not ultimately replaced by it. A considerable replacement of the walls must have taken place, and, therefore, only a small fraction of the mass represents the original cell fibers of the structures that are still visible.

\section{METHODS OF EXAMINING SAMPLES.}

\section{PREPARATION OF THIN SECTIONS.}

\section{SELECTION OF THE SPECIMEN.}

Examination of thin-ground sections under the microscope has proved the most successful and most satisfactory method. In such thin sections the coal is examined in its original chemical and physical condition and natural color. Nothing whaterer has been changed except that the coal has been ground thin enough to be transparent. Sections have been prepared thin enough to permit photography through the microscope at a magnification as high as 2,000 di-

a Hickling. George, A contribution of the micropetrology of coal : Trans. Inst. Miin. Eng., vol. 53, 1917, pp. 137-158; abstracted in Coll. Guard., vol. 113, 1917, pp. 141-443. 
ameters. Some skill, experience, and patience, however, are required to prepare them.

A piece or block of coal with few cracks or checks was chosen for preparation; one without any checks is best, alihough this was not always possible to obtain.

\section{PREPARATION OF THE PLANE SURFACE.}

The block chosen was cut to a size convenient to handle, and one surface was ground to the size desired for the section. The larger the section the more difficult it is to grind, but the greater is its value. The most desirable size is about three-fourths of an inch long and one-half of an inch wide. The surface selected for the section was ground to a perfect plane. If it was to be a cross section, it was ground at right angles to the bedding planes; if it was to be a horizontal section it was ground as nearly horizontal as possible to the bedding planes. This plane surface was then polished to remove microscopic scratches. It has not been possible to obtain a surface entirely free from such scratches, nor is it advisable to do so, as the time spent on polishing is worth more than the benefit derived from a scratchless surface.

The first rough grinding was done with fine powdered carborundlum paste on a wheel of carborundum of fine texture. When the blocks had been cut down to the plane desired, the grinding was continued on the same carborundum wheel without the abrasive, but with a fine stream of water playing on the plane until the surface was quite smooth. Most bituminous coals are not damaged by water if soaked for a few minute only. Water will not adhere readily to a newly cut surface because of the differences in surface tension. The surface was then smoothed by hand on a very fine hone on which a fine stream of water played. From time to time the hone was rubbed down with a second hone, or "rubber' furnished with "bluestone" hones, as when a carpenter makes a lather, in order to remove fine particles of coal that are apt to stick or gum to the hone. This last process polished the surface enough if carefully done; if further polishing was found necessary the surface was rubbed carefully on a leather block strop.

When the surface, which must be plane, was properly polished, the block was cemented on an object slide, the polished surface being toward the slide.

\section{THE CEMENT.}

The cement used to cement the specimens to the object slide was made of three parts of Canada balsam and two parts of marine glue, heated together in a drying oven at a temperature of about $105^{\circ} \mathrm{C}$. The proper consistence was determined by trial. It should be such that the cement when cooled will harden and yet not be brittle. 'The 
success of the process depends to a great degree on proper consistence of the cement. When a portion of cement had been prepared it was put away, protected from dust and heat, for future use.

\section{WATERPROOFING THE SPECIMENS.}

Before the block was cemented to the object slide the prepared surface was waterproofecl. Inless this was done the section, when it became quite thin during the next step of grinding, absorbed enough water to cause it to swell, buckle, and finally peel off.

Waterproofing was done by soaking the prepared surface for a few minutes in paraffin after both the specimen and the paraffin had been heated to about $105^{\circ} \mathrm{C}$.

\section{CEMENTING THE BLOCK ON THE SLIDE}

All superfluous paraffin was then wiped off the prepared surface. The object slide and the prepared surface with a bit of the cement on each were left in the drying oven at a temperature of $105^{\circ} \mathrm{C}$. until the cement was molten and contained no gas bubbles. The coal was pressed with a clamp onto the warmed slide as close to it as possible, taking care that no air bubbles got between or remained between the sample and the slide. and that the clamp was screwed down so as not to bend the block of coal or the slide and spoil the specimen. It was then left to cool slowly to room temperature.

\section{THE SECOND GRINDING.}

After the preparation had cooled the block of coal was ground down roughly on the carborundum wheel with the aid of the carborundum powder and water. Then without the powder and after every particle of the carborundum powder had been rinsed off the section was carefully ground down further on the carborundum wheel as thin as could be done without endangering it.

\section{THE FINAL GRINDING.}

The section was finally ground down by hand on the fine hone and in the same manner as in the first step. Great care had to be taken as the section approached the required thimness. To keep the grinding even the section was examined from time to time under the microscope.

In cold weather the water used in the grinding had to be warmed to room temperature or slightly higher.

\section{THE PREPARATION OF POLISHED SURFACES FOR OBLIQUE ILIUMINATION.}

The surfaces for this method of eximination were prepared exactly as the plane surface for thin section, except for the final finish. 
After the surface had been smoothed enough in the wet way on the hone, both hone and specimen were carefully dried. The grinding was then continued with long eren strokes in one direction only until the surface was sufficiently polished. Care had to be taken to keep all grit and dirt from coal and hone, in order to prevent scratching. This process gives the components in the coal clean sharply cut edges or cross sections. The preparation could not be further polished in any way without smearing the various components over the surface, making the surface useless for photography and less valuable for direct microscopic examination.

The specimens thus prepared for examination and photography with oblique illumination may well be used later for preparing thin sections, provided they have not been spoiled by too strong a light, or rather by too high a temperature. Strong light is necessary in making a photomicrograph from such a surface, and the heat accompanying it often cracks the coal and renders the surface uneven and useless for a thin section.

\section{ORIGIN OF PEAT.}

That coal has been formed from plants is no longer doubted by anyone who is familiar with the subject. But the exact manner in which plant substances were transformed into coal is still under discussion. The writer is thoroughly convinced, by his own studies and the studies of other investigators, that coals had their origin in peat beds.

The origin of peat must be analogous to that of coal, because its components are in every respect analogous to those of coal. A knowledge of peat, therefore, will help to explain much in coal that otherwise could not be clearly understood or not understood at all.

\section{PEAT DEPOSITS.}

\section{OCCURRENCE.}

A peat bog may be known as a tamarack swamp, cedar swamp, a black-ash swamp, a cypress swamp, a marsh, or a slough, according to the kinds of plants that form the main vegetation of the bog. Such swamps are found all over the United States, but are particularly abundant because of the many lakes and ponds formed there at the retreat of the great continental ice sheet in the northern tier of States east of the Red River Valley. Some swamps are of considerable size and have become well known, like the Dismal Swamp of Virginia and North Carolina. Many of these swamps are filled with a dense growth of trees or with trees and underbrush; some are covered with a dense growth of shrubbery only, others have a dense growth of sedges, grasses, bullrushes, and other herbaceous plants. In some there is an open area of water near the center. 
Many such swamps have been reclaimed; despoiled of all original plant growth, they serve as fertile pastures or cultivated lands. Those that relate to our subject are those that are overgrown densely with trees and shrubbery, with coniferous trees, such as the white cedar (Thuya occidentalis), the black spruce (Picea mariana), and the tamarack (Larix Zaricina) predominating. Some of these swamps are almost impenetrable because of the tangle of fallen and reclining trees intergrown with shrubbery of many kinds. A general idea may be obtained from the photographs shown in Plates I-III, taken in different peat swamps of Wisconsin. These show the general density of the growth, the reclining position of many of the trees, and the contour of the substratum. Some trees are down, some are already partly covered, and others, as indicated by humps, are entirely covered by débris. On account of their uniform hold in the loose soil, many of the trees in the reclining position gradually come down further and further year by year, until they lie prostrate on the ground. In this position they may die and gradually rot or continue to live for an indefinite time; in either case their trunks become covered by the general débris in the years that follow. Other trees are overturned rapidly by storms and heavy snowfalls. To the fallen trunks and limbs are added year by year limbs, twigs, leaves, fruits, spores, and pollens.

\section{DISINTEGRATION OF PLANT SUBSTANCES.}

As long as this mass of plant substances is exposed to the air in moist surroundings much of it rots with comparative rapidity and much of the woody material and leaves and many of the herbaceous plants disintegrate and form a general débris and attritus. When covered by the wet deposits of subsequent years decay takes place slowly and further disintegration practically ceases.

The greatest and the quickest transformation of vegetable substances into peat is on the surface where there is free access of oxygen and exposure to the weather. Initial decay, particularly in the wood, is brought about by fungi. The woody substance by becoming soggy and taking up much moisture, soon becomes the abode of a host of decomposing agencies, both fungi and bacteria, as well as small animal organisms and burrowing and boring insects. Disintegration follows when the parts become soft and brittle and yield to such forces as wind, rain, snow, gravitation, boring insects and beasts and birds, of which gravitation is the chief.

A knowledge of the mode of disintegration of the woody parts is of great value in the study of coal, as the state of division of the woody components of peat closely parallels that of the corresponding components of coal. Examination of the chips of wood in peat shows by far the larger number are small flat thin pieces; many of 
these pieces may be separated into several thinner ones. (Pls. IV, VI, VII, and VIII.) Examination of the anthraxylon pieces in coal shows a similar condition. There is a reason why the stems of trees or shrubs should form such pieces on disintegration.

Several modes of disintegration can be recognized, each one resulting in similar flat and thin, or scaly, woody remnants. In peat the most prevalent condition and the one most frequently recognized in disintegrated parts of conifers, is caused by the exfoliation of the annual growth rings through differential decay. As is well known all stems of exogenous plants grow through an annual increment of new wood or fibers developed in the phloem, which lies between the wood and the bark; but this growth is not uniform throughout the growing season. During part of the time the cells grow much faster than at other times and the cells become relatively large while the cell walls remain relatively thin thus forming what is known as the spring wood; then at other times the growth is slower and the cells added are small and the walls relatively thick, and the increment is known as autumn wood. At one time of the growing season, the "incrustation" of the cell walls may be slight, and at other times relatively heavy. Certain parts of the growing ring therefore decay more readily than others, and in consequence lesions are formed in the regions that decay the more easily. When the whole stem or piece of wood has reached a certain stage of decay and has become soft and brittle, it gradually falls to pieces through any slight disturbance, or its own weight. Disintegration takes place by means of exfoliation along those growth rings that have decayed most, resulting in many thin tangential leaflike sheets that easily break up into smaller fragments.

Some trees are more subject to this mode of disintegration than are others. The basswood (Tilia Americana) is a well known example. The stem of this tree at a certain stage of decay may be peeled off and separated into large thin sheets that easily break into smaller pieces. A casual examination of the detritus of a peat bog reveals numerous wood fragments of greatly varying size in a similar state of division. (Pls. IV-VIII.)

A second mode of disintegration is by splitting along the medullary rays. This method appears to be common in trees with broad rays, as the elm and the oak. The ray cells decay more readily than the other parts of the wood. In trees with broad rays the lesions are formed along radial planes, and when the wood has reached a certain degree of decay it will separate along those weakened planes. The result is similar to that of disintegration through exfoliation along the annual growth rings, except that thin radial plates are formed instead of tangential plates. 
Many of the trunks and larger stems, or the larger parts of them, withstand the mechanical separation and disintegration and are gradually buried by the débris of subsequent years. These are, however, in various stages of decay and are infested with bacteria and fungal growths, although occasionally a stem is found that is apparently sound. Usually they are covered with a profusion of polyporus fungi, lichens, and liverworts.

\section{COMPOSITION OF A BOG.}

On the surface of many peat bogs in central Wisconsin, besides the plants still living are trunks and stems of trees, limbs and branches in various lengths, pieces or chips of wood of various sizes and shapes, leaves, mosses, lichens, liverworts, and fungi in various stages of decay and maceration; particularly noticeable are the leaves or needles of the different conifers. (Plate III, $A$ and $B$.) Settled between the interstices of the debris are fine bits of anything that happens to grow in the swamp, the material that furnishes the fine microscopic débris, or attritus.

Beneath the uppermost strata is a wet mass of more or less macerated plant débris, a soil of black mud, containing many fragments of semidecayed wood. This mud, which may be from a few feet to 30 feet or more deep, is filled with trunks of trees more or less whole and pieces of trunks, roots, and branches of all sizes in various stages of decay. The contents of the whole swamp from the bottom up is similar to that of the surface layer.

By far the larger part of the mass is water.

\section{THE COIMPONENTS IN DETAIL.}

THE ATTRITUS.

When the amorphous appearing mass, the black mud, is examined under a miscroscope it is found to be composed almost entirely of definite and specific particles recognizable as portions of plant tissues or organs; only a relatively small amount is amorphous. Among the recognizable particles are whole cells or parts of cells and small complexes of cells of many descriptions; bits of tissues of many kinds of plants; parts of various organs, such as root hairs and rootlets; moss protenemas, parts of mosses, fungal hyphi, bits of leaves and bark, pollen grains, spores, bits of leaf cuticles and resin particles. These are all miscroscopic in size and would form a very fine silt if separated from the rest of the peat. If in dried condition they would form a fine dust or attritus, and will, therefore, be called the attritus. 
The most familiar components that may be examined under a hand lens or low-powered microscope are very small bits of woody tissues, parts of various herbaceous tissues, parts of rootlets, the whole or parts of moss plantlets, small pieces of bark. parts of leaves of angiosperms, gymnosperms, and grasses, and especially cuticles.

The woody parts of the plants show a gradation of sizes from the most minute to that of almost whole stems or logs. The gradation of the smaller woody components is of special interest and significance because these pieces are of a peculiar nature.

THE SM.ALLER WOOIY COMIONENTS.

In a lump of peat taken from a wooly Wisconsin swamp (Pl. IV,$A$ ), wood forms a large proportion of the components and the largest proportion of the woody components consists of thin, flat pieces, ranging in sizes from those easily visible to the naked eye to those about the size of a postage stamp. (l'l. VI.) When closely examined they are seen to be either tangential shells formed through an exfoliation along the spring wood of an annual ring or through a rupture of the decaying wood along the ray parenchyma of the stem or log.

When wet these chips or pieces may easily be split into still thinner ones; on drying, the cells collapse and the pieces become very thin and hard. (Pl. VII, $A$ and $B$.) The tangential shells are chiefly derived from coniferous trees, and the radial plates from angiosperms. Other modes of disintegration may be observed, but as they are chiefly of interest in the transformation process, they need not be discussed here.

\section{LARGER WOONY COMPONENTS.}

The larger woody components are broken limbs, twigs, branches, and roots. Most of them are rather short, cylindrical pieces, although some are fractured or split, and they are in same condition of decay as the chips.

\section{LOGS AND LARGER P.IRTS IF TREES.}

The numerous logs and larger parts of trees encountered in sounding a bog are in various stages of lecay. Usually the deeper the $\log$ is embedded the more it is clerayed. Toward the surface may be some in which the wood is still hard ancl sound. Often trunks are found in which an outer shell has been transformed into a mushy or plastic mass, whereas the central portion is still hard and sound. Most of the lags, particularly those some distance below the 
surface, have been transformed into peat and may easily be penetrated with the sounder or cut with the spade. The wood in these is in the same condition as that of the smaller fragments. The pulp of many of such buried logs varies in color from a yellow to a light brown when first taken out, but after exposure to the air it soon turns dark brown, the usual color of peat.

\section{PROPORTION OF COMPONENTS.}

The proportion of any of the components in a sample of peat from a bog varies considerably according to the depth, the place in the swamp, and the particular bog from which the sample is taken.

The ecological conditions, which determine the accession of different plant societies, change materially from time to time during the history of a bog; the conditions of several parts of the same bog may differ considerably and those of several bogs may differ so much as to cause the plant societies in each to be altogether different. The kinds of plants that contribute to a bog determine largely the degree of maceration and, naturally, the plant remains found in a bog.

SPORES, POLLENS, CU'TICLES, AND RESINS.

A few of the components mentioned form a relatively small part of the total plant products, but are of great importance in the final composition of the deposit. These are the spores of Pteridophytes, pollen grains of both Gymnosperms and Angiosperms, the resinous parts of many plants, especially conifers, and the cuticular tissues of plants, particularly the cuticles of leaves.

The spores of most all the Pteridophytes, like those of the ordinary ferns, the horse-tails and the ground-pines or clubmosses (Plate VIII, $B$ ) have comparatively thick outer coats or exines composed of a mixture of resins, waxes, oils and cutocellulose, that are resistant to decay. Likewise the pollen grains of all plants contain a spore-coat or exine of similar composition, although they are much thinner than those of the Pteridophytic spores. The cellulosic plant products, that is, the woody parts, largely decompose and are lost to the deposit, whereas the spore-coats decay relatively little. There is consequently an enrichment or concentration of the more stable components, which are therefore, present in the final product in appreciable amounts. The annual increment of the cellulosic part of plants over the annual production of spore-exines is not large and in some cases the two are nearly equal. Therefore, the total production of exine matter during the whole life of the plant is not small in comparison with the total mass of woody tissue.

The same is true for the cuticular tissues. It is well known that all leaves and needles, the younger stems, and often also the older 
stems, fruits and berries are covered with a membrane of a composition similar to that of the spore and pollen exines and equally resistant to decay. Although in many plants this cuticle is very thin, in many others it is thick. In the needles of conifers and many ferns the cuticle is well developed. (Pl. IX, A and B.) Often there is an additional layer of wax laid over the cuticular membrane, and sometimes there is on the film of wax a coat of fine hair, processes, or fine granules, also composed of a waxy substance. On the leaves of some plants the coat of wax is so thick that it is commercially valuable. Occasionally both saturated and unsaturated higher paraffins, the most resistant substances known, are present in such cuticles.

The resinous matter in peat deposits originates in various ways. Almost all coniferous trees contain so-called resin cells distributed throughout the wood. Some conifers, as the tamarack, contain fissures and reservoirs in which resinous matter is collected. Often these reservoirs are so large that the amount of resin contained in a single tree may anount to several gallons. In the bark of coniferous trees the resin occurs in the parenchymatous cells and blisters or in reservoirs as in the balsam fir (1bies balsamea). The resin in the genus Pinus amounts approximately to 10 per cent of the dry weight. Flowering plants as well as the conifers may contain resinous matters both in the wood and the bark. The leaves and needles of the conifers and of the flowering plants may also contain much resinous matter. Resinous matter is not subject to bacterial decay and is left behind when the resin-containing tissues or organs have disappeared through decay.

\section{THE AMORIHOUS CONSTITLENTS.}

A varying amount of the mass of peat is in an amorphous state. It is surprisingly small, and is composed of plant matter so finely macerated as to have lost all cell structure. Careful examination shows a gradation of sizes of the particles composing this attritus, the particles ranging from those easily visible under the microscope down to those in a colloidal conclition and visible only by ultramicroscopic means.

Some of the larger particles show characteristics of the cell, others have lost all such identity.

All these particles are poorly defined and are ustally ragged and rough in appearance. When examined by ultramicroscopic methods a large proportion of them are seen to consist of numerous submicroscopic particles or micelli, loosely united and having large intermicellar spaces between them. 


\section{THE PHYSICAL STRUCTURE OF THE TISSUES REMAINING IN PEAT.}

After the excess water has been allowed to drain off completely. a mass of peat or any piece of wood in it, if compressed, will give up a large amount of water, and even when air-dried peat contains from 12 to 17 per nt of water. This indicates that the mass is in a peculiar physical condition.

Almost any of the pieces of wood taken from a matured part of the bog is found to be quite plastic, and may be kneaded much like clay. When a piece of such wood is partly dried it has a consistence similar to that of art gum; when completely air-dried, it has a horny consistence, sometimes resembling hard rubber.

When the wood is examined in thin sections under a high powered microscope the cell walls are seen to have a granular structure and no longer appear compact and homogeneous as in living or sound wood. The cause of this granular appearance becomes evident when the cel] walls in very thin sections are examined by ultramicroscopic means. The cell walls are composed of innumerable very fine particles or micelli with relatively large intermicellar spaces that are filled with water. This is true not only of the cell walls of the woody components but also of the walls of all those that at one time were composed of cellulosic or lignocellulosic matter. Is all plant tissues, aside from a few adventitious substances and the little inorganic matter in them, are composed of cellulose or lignocellulose, cell walls of practically the whole mass are in this peculiar condition.

There is a wide range in this condition of the mass, depending largely upon the maturity of the peat. This condition is a phase of the transformation of the living plant substances into peat anc eventually into coal. In the Wisconsin bogs under discussion, which areraged from 8 to 13 feet in depth, the condition became more uni form with depth. In other words, the older the deposit the mor mature is the peat and the more uniform its physical structure. Th greatest difference in structure is found at the surface and within fer feet of it.

Moreover, the further the mass has advanced toward a uniforn condition the less cellulose and lignocellulose it contains. In well matured peat no cellulose or lignocellulose can be detected by th methods of test generally applied. The change of the physical con dition of the wood parallels the chemical change.

THE CELL WALLS IN A STATE OF HYDROGEL.

As has been shown, the remaining cell walls of the components o peat are an aggregate of extremely small particles or micelli an these micelli are not risible with the ordinary microscope. A col lection of such particles, whether suspended in water or whethe 
packed closely together with only thin films of water or air between them, is termed a colloid. When such fine particles are suspended in water the colloid is called a hydrosol or colloidal solution; if the particles are so closely packed together as to be separated by only a thin film of water, the particles having lost their individuality and holding together to form a jelly-like mass, the colloid is called a hydrogel. The remaining cell walls of the plant substances in peat are in a state of hydrogel.

It is well known that when the particles of any substance in such a fine state of division are brought close (nough together-that is, within the radius of their sphere of attraction--they form a solid mass. If a mass of jelly, which is a hydrogel in terms of colloidal chemistry, is left to dry it forms a hard mass for that same reason. For that reason, also, when the woody components of well-matured peat dries they form a hard brittle mass; likewise all the peat will form a hard brittle mass when dried provided the peat is well matured, or in other words if the cell walls comprising it have approached a typical hydrogel. The more matured the mass, the harder and the more coal-like will it be when dry.

Peat in any stage of maturation may be transformed by artificial means into a typical hydrogel, and such a mass when desiccated will resemble coal very closely, in fact it will be harder and more solid than many bituminous coals.

\section{OTHER PROPERTIES OF PEAT.}

Besides its property of forming a hard mass when dried, peat owes many peculiar and striking properties to its colloidal condition. To call attention to a few of them may be of value. The property of retaining water with tenacity has caused difficulty in commercializing peat as a fuel. The absorption of gases, particularly oxygen, has been variously applieil. Peat absorbs odors readily and for this reason is a valuable stable litter. It absorbs various substances in solution; aids in decomposing certain compounds in solution, especially electrolytes that dissociate easily; and it is a strong reducing agent.

PRESERVATION OF PLANT TISSUES.

The mechanical cell structure-that is, the form and the shape of cells of the woody components from the most minute fragment to the largest present-has been well preserved in peat, the cells and fibers having retained their original form and shape remarkably. Only occasionally have the walls become very thin and collapsed. Fragments of other tissues, particularly those of the mosses, have retained their cell structure to a similar degree. Leaflets and whole 
or nearly whole plantlets may often be found with every detail of their organization retained. Often parts of succulent stems are found similarly well preserved, although it is chiefly among the latter that the cells have collapsed.

As there is no further mechanical change in the components, after they have been submerged under subsequent matter, except a complete collapse of the cells caused by downward pressure and the withdrawal of the water, the finding of so much well-preserved plant structure in the coals, as is shown later, is not surprising. After the plant residue is once covered it is practically removed from all mechanical agents and no further maceration takes place.

\section{STRUCTURE IN COAL.}

\section{GENERAL APPEARANCE UNDER THE MICROSCOPE.}

Coal may now be examined with a clearer understanding of the terms and a more intelligent interpretation of the characters observed, because, as the author believes, coal deposits and peat deposits have been formed in analogous ways, and because the constituents in coal and peat are analogous in erery respect, except that the plants that contributed to the deposit of each differed in kind. although not materially in cell structure and chemical composition.

For a general study of the outward appearance of bituminous coal a lump or block from almost any bituminous coal might be selected. Pieces of coal from the Pittsburgh bed near Pittsburgh, Pa., (Pl. XXXVI, B), from Sesser, Ill. (Pl. X), from the mine of the Benton Coal Co. near Benton, Ill. (Pls. XI-XIII), and one from the Vandalia mine near Terre Haute, Ind. (Pl. CXLII), have been chosen for the illustrations shown in the report, as they will illustrate the microscopic appearances of any ordinary bituminous coal.

\section{THE LAMINATION SEEN IN COAL.}

A bed or bank of any bituminous coal is readily seen to be laminated (Pl. XXXVI, $A$ ) ; likewise a block or lump of coal when examined more closely is seen to be composed of many layers or seams differing from one another in color, texture, fracture, degree of absorbing and reflecting light, and differing greatly in thickness (Pls. X-XIII; Pl. XXXVI, $B$, and Pl. CXLII).

A little study shows that in general there are two kinds of layers or striæ. One is jetty black, and usually has a high luster, reflects light readily, is more compact and breaks with a decidedly conchoidal fracture; the other is grayish black, has a dull appearance, and little or no luster, does not reflect light as readily but rather refracts it, is less compact and breaks irregularly. The former is 
usually found as lenses of varying thicknesses and widths and on close examination is seen to be embedded in the latter; this last characteristic is most evident in extensive exposures or in large blocks. Even with the naked eye, after a careful examination, the duller layers or striæ are seen also to be composed of numerous thin alternating bright and dull sheets. This is brought out clearly and distinctly in a polished vertical section slightly magnified.

When coal is examined along cleavage surfaces parallel to the bedding planes, it is seen to contain charcoal, also called "mother coal " or mineral charcoal, in thin layers or laminæ. As the charcoal stands out prominently on the horizontal cleavage faces and is readily recognized, even when present only in small quantities or thin sheets, the earlier observers distinguished only two classes of coal-compact coal and charcoal.

But when coal is examined along the rertical cleavage surfaces only, the charcoal appears as dull coal, is overlooked, only dull and bright laminæ being observed.

As regards types of components, ordinary bituminous coal may be said to have three, dull coal, bright coal, and charcoal; but as regards differences in compactness or hardness, coal may be said to have two components, compact coal and charcoal, as described by earlier investigators. In the latter classification the dull laminæ and the bright laminx of the compact coal must be distinguished.

Although these differences have been recognized from an early date, no complete or definite explanation of the true nature of dull and bright laminæ in the bituminous coals had been offered, or, if correct interpretations have been given in part, no definite proof of their differences has been offererl. One of the objects of this bulletin is to show the real nature of the dull and bright laminæ.

\section{THE "BRIGHT COAL" OR ANTHRAXYLON.}

The most prominent features in Plates X-XIII are the broad black bands running through these pieces-the so-called "bright coal," "jet coal," or "glanz coal" of other authors. These black bands are most always lenticular, or broad, flat pieces that have a wedgeshaped termination. The black bands run for some distance through a larger block or even a long distance through the coal in the seam before they terminate. In a small piece of coal they generally continue through the piece from one side to the other, and for that reason convey the idea of laminæ or layers instead of inclusions, but it is not rare to find complete lenses or their edges in small blocks. Such terminations are shown in Plate XI; $A$ and $B$, Plate XII, and Plate XIII. ${ }^{a}$ The bands of the bright coal should there-

$a$ White, David, and Thiessen, Reinhardt, The origin of coal : Bull. 38, Bureau of Mines, 1914 , pp. $140-155$. 
fore properly be called lenticular laminæ. These lenticular laminæ vary in thickness, but are rarely more than $10 \mathrm{~mm}$. or threc-eighths of an inch thick. The layers shown in Plates XII and XIII of coal from the mine of the Benton Coal Co. are about $9 \mathrm{~mm}$. thick and are rare. The thickest layers in the coal from Sesser, Ill. (a, Pl. X), measure between 4 and $5 \mathrm{~mm}$. and are of common size. The layer a (Pl. XXXVI, B) of coal from the Pittsburgh bed is 9 to $10 \mathrm{~mm}$. thick. The other layers in this block are very thin, a characteristic of the coal from this bed. All these black bands shown in the photographs-the so-called "glanz coal," "jet coal," "bright coal," "humus coal," of various authors-represent parts of definite components of the woody parts of plants; that is, parts once pieces of logs or stems, branches, twigs, and roots, but now much compressed. They correspond to the larger pieces of woody peat, such as pieces of $\log _{\mathrm{s}}$ or stems, branches, twigs, and roots. Being definite pieces of coal derived from wood, these components are called anthraxylon, meaning coal wood, from anthrex, coal and xylon, wood.

\section{THE "DULL COAL."}

The characters that stand out next in prominence in Plates $\mathrm{X}$ XIII are the lighter striated bands or lavers between the dark bands. These represent the so-called "dull coal," "canneloid coal," "matt coal" of other investigators, because they have a dull look compared with the layers of the "bright coal."

This dull coal is composed of a general débris derived from a variety of plant products and corresponds to the general débris of peat deposits. When the rertical face of a large block or of a coal bank is examined the black and brighter bands are not continuous, but are definite objects embedded in or surrounded mostly by the "dull coal," exactly as the larger pieces of woody peat are embedded in the "black mud" or general débris.

A more careful examination of the "dull coal" shows that this in turn is composed of many thin light and dull sheets. In many coals this thin sublamination is well defined, as is shown by Plate XI, $A$, and Plate XXXVI, $B$. The brighter sublaminæ again, represent components derived from smaller pieces of woody tissues and hence also are anthraxylon components that correspond in every respect to the smaller fragments or woody chips in peat, such as are shown in Plate IV-VIII. These, like the larger anthraxylon components, vary greatly in size. There is a complete gradation of thickness from the thinnest anthraxylon; but a few microns thick, to the larger anthraxylon, many centimeters thick; so that the distinction drawn between the larger and the smaller anthraxylon components is arbitrary. But as the thickness of a relatively large number of the 
smaller components varies within certain limits, the distinction between "dull coal" and "bright coal" holds for most coals.

\section{THE ATTRITUS.}

That part of the "dull coal" in which the smaller anthraxylon chips are embedded, represented in gray or the lighter thin sheets in the photographs, is finely divided matter and corresponds to the fine 'black "mud," or attritus of peat, and, as will be shown later, is similarly composed. This component of the coal will, therefore, be called the attritus.

The attritus forms the groundmass in which the smaller components, such as the smaller anthraxylon, cuticles, and megaspores are embedded in the same way that the mixture of sand and cement in concrete forms the ground mass for the crushed stone and gravel, and it is designated the general débris which forms the so-called "dull coal." This general debris or " dull coal" in turn is the embedding medium of the larger components in coal, in the same way that the mixture of cement, sand, gravel, and crushed stone forms the embedling medium of the larger stones in concrete.

The characters described above are true of all ordinary bituminous coals, and coals from any locality might have been chosen equally well for illustration. A careful study of lumps of any bituminous coal that may be at hand will show the proportion of the dull layers and bright layers to each other, and the sublamination of the dull laminæ into many thin bright and dull sheets.

\section{EXAMINATION OF VERTICAL SECTIONS AT LOW MAGNIFICATION.}

The mode of the fine lamination is seen much better in a vertical section at a relatively low magnification, either in a polished opaque section by means of a reflected light or in a thin section by transmitted light. Examination in the latter way is an essential step from the gross aspect, or macroscopic appearance of coal, to its appearance in thin sections at relatively high magnification. It is also essential in obtaining the relationship of the woody components to the. attritus as well as the relative proportion of the two. Representative sections of this kind, magnified 10 diameters, are discussed in detail.

In the photographs the larger anthraxylon components or "bright coal " are designated by the letter a, while the "dull coal," or general débris, represented by gray, fincly striated areas or bands, is designated by the letter $d$. The numbers preceding these letters indicate either the order or situation in the photograph or refer to the same layer or band in some other photograph with corresponding letters and numbers. 
STRUCTURE OF THE COAL FROM THE BENTON MINE, BENTON, IIL.

The coal from the Benton mine, near Benton, Ill., is relatively simple in structure and shows defininite alternation of so-called bright laminx and dull laminæ. The macroscopic appearance of a piece of this coal is shown in Plate XII.

Plate $X V^{r}$ represents a section of the piece of coal represented at natural size in Plate XII, from the area formed by the intersection of the lines $\mathrm{xx}, \mathrm{ry}$, and $\mathrm{nn}, \mathrm{mm}$, magnified 10 times. The bands or striae 1-a, 2-d, 3-a, 4-d, 5-a, 6-d, $7-\mathrm{a}$, and $8-\mathrm{d}$ in Plate $\mathrm{XV}$ are the same as those of the same lettering and enumeration in Plate XII. Beginning at the top of the photograph there is, first, a layer of bright coal or anthraxylon, 1-a, containing a fissure filled with quartz; then a layer of cébris or "dull" coal, 2-1l: next a thin piece of poorly defined anthraxylon, 3-a, between the layers of débris, 2-d and $4-d$. In the middle of the photograph is the relatively thick piece of anthraxylon, 5-a, containing a characteristic vertical fissure, filled with quartz. Bekow this piece are very thin alternating sheets of débris and anthraxy lon that grade into the débris, ${ }^{6}-\mathrm{d}$. This grades off similarly into the anthraxylon, $7-a$; finally, at the bottom is the débris, 8-d, which includes a small piece of charcoal, $c$.

The illustrations show a vertical surface of the coal; that is, a cut perpendicular to the plane of the bedding; hence merely the cut edges or the ends of thin shects of débris and of woody fragments are seen. If the piece of coal were split along the bedding planes these thin and flat components would be seen in their horizontal positions. Such horizontal clearage surfaces will be discussed later and correlated with the cross sections. (For horizontal cleavage planes see Pls. XXV-XXX.)

The photograph ( $\mathrm{Pl} . \mathrm{XV}$ ) clearly shows that the laminse of débris or "dull coal," designated by $2-\mathrm{d}, 4-\mathrm{d}, 6-\mathrm{d}$, and $8-\mathrm{d}$, are in turn composed mainly of two constituents, the one gray and the other darker, arranged more or less in alternating horizontal sheets. A closer inspection shows that many of these sheets extend across the photograph, others terminate in it, and many lie entirely within its borders. If the sections were wide enough all the sheets would be seen to terminate within a comparatively short distance. Some, as seen in cross section, are linear, others slightly lenticular, and still others more or less irregular. The dark sheets for the most part were at one time small fragments of woody matter analogous to the smaller chips forming an important part in peat (Pl. VI) and are the smaller anthraxylon components. The gray sheets are for the mont part the finely divided matter derived from various sources, including the spore matter, and hence are the attritus. 
Plate XVI is taken from the same piece of coal, though from another side and higher up. It shows but one thick anthraxylon strip in the center, 2-a, and a part of a thicker one at the bottom, 5-a. The "dull coal" at 1-d, ahove the anthraxylon 2-a, is regularly grouped into dense, narrow long patches separated by black strips derived from woody tissues of plants. When these patches of débris are examined closely they are found to be laminated further into light and dark strips, the lighter representing attritus and the darker, anthraxylon. In this part of the "dull coal" thin, welldefined light lines may be observed, double in several places; these are the edges of cuticles. The sheets of attritus are more or less contorted at $3-\mathrm{d}$ to $4-\mathrm{d}$, as if they were folded upon themselves. The black or anthraxylon components also are irregular. In other respects the components are similar to those observed in Plate XV. The gray areas are analogous to the black mud in the peat bog, are similarly composed, and are plainly attritus.

\section{STRUCTURE OF THE COAL FROM ROYALTON, ILL.}

The coal from the Royalton mine presents fairly the average structure of the Illinois coals. Instead of showing the macroscopic aspect of this coal in a lump. a continuous area in cross section of about three inches thickness and about one-half of an inch in width of the coal is presented at a magnification of 10 diameters as a series. (Pls. XVII-XXI.) Such a continuous strip shows both the general proportion and the structure of the main components over a known thickness. If Plate XVII alone were examined, it would give the impression that the coal was composed largely of matter derived directly from wood; if, on the other hand, Plate XIX alone were examined, it would give the impression that the coal was composed of débris only. The three inches of thickness, however, shows average conditions in the compact coal at the Royalton mine, exclusive of layers containing much earthy matter, pyrite, or charcoal. A similar illustration of coal from the top to the bottom of the bed would show only minor differences.

At the top of Plate XVII, 1-a is a thick woody or anthraxylon strip; the irregular strip $h$ running from side to side is the last vestige of the inner part of a hollow stem, such stems being common in many of the woody components in all coals. Below the anthraxylon 1-a is a "woody" débris, $2-d$. The fine line, in about the middle of this sheet, running almost across the photograph is the cut edge of a leaf cuticle. Then 3-a is another anthraxylon layer. The irregular streak running through this part is a fracture, such as often is seen in the thicker anthraxylon components. Below this is a layer of débris, 4-d, in which the constituents are lumped into lenticular 
or wedge-shaped masses; 5 -a is a thin piece of anthraxylon, showing clearly its lenticular shape; $6-d$ is a layer of débris, rather woody in the upper part and less woody in the lower part; 7-a is another anthraxylon piece with a characteristic fracture running through it. In the débris (8-d, Pl. XVIII) the cut ends of the so-called rodlets, very common in most coals, are noticeable. At $9-\mathrm{a}$ is another piece of woody coal without a horizontal fracture but containing a vertical fissure filled with quartz. The remainder of the photograph is an anthraxylous débris, 10-d. The darker strips are mostly thin chips of anthraxylon, and the lighter parts are an attritus of finely macerated plant products. This attritus is shown in detail later (Pl. CVI). In 10-p is included a chip of semi-petrified wood. The lower part of this layer, 11-a, is very anthraxylous. Plate XIX and a part of Plate XX shows a thick layer of cébris, $12-\mathrm{d}$ to $15-\mathrm{d}$. In $13-\mathrm{c}$ is included a lense of carbonized and petrified matter, and from 16 to 21 , Plate XX, several anthraxylon chips alternate with débris. A thicker anthraxylon layer at 22-a is evidently a part of a hollow stem including some débris, $23-\mathrm{d}$. In the lower section of this part of the stem the evidences of remaining cell structures are clearly recognizable, even at the low magnification. The remainder of the 3 inches of coal (24-d to $26-\mathrm{d}, \mathrm{Pl}$. XXI) consists of relatively pure débris, with but one thick anthraxylon chip, 25-a. A number of the so-called rodlets are noticeable in this section, particularly from 25-d to 26-d. Plate XXII, $A$, which is not a part of the above series, shows a layer in which a large number of these rodlets are seen in cross section. Plate XXII, $B$, magnified 10 diameters, shows clearly the structure of the constituents of this coal, with inclusions of charcoal in the lower part.

\section{STRUCTURE OF THE ZEIGLER AND HART-WILLIAM̀S COALS.}

The structure of the coal from the Zeigler mine, as shown in Plate XXIII, does not differ materially from any of the other coals shown; it is very similar to the coal from the Benton mine. Attention is called to the lumping of the débris in several places, and also to the cross sections of rodlets in the upper half, a characteristic of these coals. The section shows, with the exception of the woody elements at the top and the bottom, 1-a and 5-a, a lamina rich in attrital matter. Another section from the same coal (PL. XXIV, $A$ ) shows the dull coal is in very delicate, sharply defined, thin strips consisting chiefly of cuticles. The interpretation of this section is given in the discussion of the Zeigler coal at higher magnifications (p. 85). Similar sections are found at various horizons not only in the Zeigler coal but also in the Benton and the Hart-Williams coals. 
The structure of the coal from the Hart-Williams mine, near Benton, Ill., is similar to that of the coals from the Benton and the Zeigler mines and needs no further discussion.

STRUCTURE OF THE COAL FROM SESSER, ILL.

The structure of the coal from Sesser, Ill., as seen in cross section, is much like that of the other coals already discusserl. The section shown in Plate XXIV, $B$, is mainly anthraxylous. The relatively thick anthraxylon components of the débris are separated by relatively thin sheets of attritus. In the anthraxylon component at 2-a the remains of the original cell structure are clearly shown. Plate CI, $A$, shows this part of the section at a magnification of 200 diameters. Compare Plate XXIV, $B$, with Plate C, $A$, prepared by transmitted light but at the same magnification.

\section{STRUCTURE OF THE COAL FROM BUXTON, IOWA.}

Plate CXXI, $A$ and $B$, and Plate CXXII, $A$, represent cross sections of the coal from Buxton, Iowa. In general the structure of this coal is similar to that of other coals. Two prominent characteristics are the frequent presence of megaspore-exines and sporangia and the peculiar nature of the smaller anthraxylon strips. A number of large megaspore-exines are distinctly seen at 4-sp, also a number of sporangia filled with spores at 2-s and part of a cuticle at $5-$ c, Plate CXXI, $A$.

\section{STRUCTURE OF THE PITTSBURGH COAI.}

The Pittsburgh coal in the block (Pl. XXXVI, $B$ ) contains only a few thicker lamina of the larger anthraxylon components. It is characterized by relatively thin alternating sheets of dull and bright coal rather uniformly arranged. The character of the structure is seen much better in vertical sections at a relatively low magnification.

Instead of illustrations giving a continuous, strip, Plates XXXVII-XLI, taken at 1-foot intervals from top to bottom of the 5 -foot bed at the Oak mine are shown supplemented by illustrations from other parts of the same hed. As the reader is now presumed to be familiar with the general appearance of such sections, attention is called only to characters that are new or of special interest.

Scarcity of the thicker woody elements, uniform distribution of the components, and fine lamination are noticeable throughout the series. Plate XXXVII shows a cross section taken from the first foot of coal, measuring from the roof, of the coal at the Oak mine. A large proportion of the components are layered in very thin delicate sheets 
with here and there oval inclusions. Megaspore-exines are recognizable ererywhere, particularly at 4-d. Compare Plate XXXVII with Plate XLIV, prepared from the same sample by means of transmitted light at the same magnification, and note the appearance of the same components.

Plate XXXVIII shows a cross section of the coal from the second foot of coal from the top. The anthraxylon components, shown as delicate black strips, are both thicker and more numerous than in the coal from the first foot of the bed. At various horizons, as at 4-d and $;-d$, there are indications that the anthraxylon components are not solid, but consist of a number of very thin sheets closely packed one upon the other. At 1-d a bit of semipetrified wood is included. Similar small bits are recognizable in other parts of the section. Compare Plate XXXVIII with Plate XLV, made by transmitted light at the same magnification.

In Plate XXXIX, taken from the third foot from the top of the sean, the distribution and the layering is more irregular. The proportion of the anthraxylon components has become larger than that shown in the two foregoing sections, and the attritus is somewhat lumped. Megaspores are seen in 2-d. Compare Plate XXXIX with Plate XLVI.

Plate XL represents a section from the fourth foot from the top of the seam. Although the general structure of the coal at this level is similar to that at 3 feet from the top, the photograph shows certain characters that can be seen more easily than they can be described. It has four groups of layers. The first one, 1-d and 2-d, has characteristics much like those shown in Plate XXXIX, but the one at $3-\mathrm{d}$ is very irregular and contains a number of thickwailed megaspores; the next one, at the level $4-d$, is more anthraxylous, the heavy black strips running across the photograph and representing thick chips; also a number of megaspores are visible. At $5-d$ is a fragment of petrified wood, and next to it is débris rich in spore matter. Compare Plate XL with Plate XLVII.

Plate XLI shows a cross section of the coal in the fifth foot from the top (the first foot from the floor). The coal is here decidedly more anthraxylous. Plate XLI and Plate XXXVII differ decidedly in the amount of anthraxylous matter present and also in the composition of the débris. Anthraxylous components of the thickness shown at the level 2-a (Pl. XLI) are quite common at this horizon of the seam. Compare Plate XLI with Plate XLVIII, $A$.

Plates XLII and XIIII present two different sections of the coal from the Pittsburgh bel at the experimental mine. The structure is similar to that of coal from the Oak mine, particularly the section 3 feet from the top. 
The structure of the coal from the Oak mine and the experimental mine is characteristic of the Pittsburgh coal at any of the localities from which samples were taken, namely, Bruceton, Madison, Connellsville, in Pennsylvania, several unknown places, and near Hobart Street in Pittsburgh, and a mine in Ohio, near Moundsville, W. Va.

\section{SIMILARITY OF VERTICAL SECTIONS OF ALL COALS.}

The general appearance of the vertical sections of all the coals examined is much the same. Many sections of the coals have been compared and every one has revealed similar characteristics. Further, no matter from what coal the section was chosen nor from what part of the coal seam, these characteristics have been similar, as is shown in the illustrations. The conclusion, therefore, can safely be drawn that nearly all the ordinary Paleozoic bituminous coals are of similar structure, so far as can be learned from vertical sections.

\section{EXAMINATION OF HORIZONTAL CLEAVAGE SURFACES.}

Although the appearance of the horizontal surface fracture of coal has been the object of much discussion and has furnished material for a voluminous literature, some first-hand observations and original illustrations of it will be profitable for the sake of completeness and of having the matter immediately available and fresh in mind.

When, in the past, horizontal fractures have been discussed and illustrated, the woody structure seen on the surface has been termed charcoal or mother of coal; the fractures described were chiefly through larger pieces of charcoal. Frequently, also, objects described as charcoal were in reality pieces of solid anthraxylous coal, or the distinction between charcoal and solid anthraxylon components was not always clearly drawn, or the two were not clearly identified. Although there is a clear distinction between the ordinary woody components of the compact coal and the average charcoal observed, no hard and fast line exists between the two, as they are to some degree intergradient or transition forms.

In this report cleavages through the compact coal only are referred to, and splits through charcoal are ignored as far as possible or very carefully avoided. The discussion refers to compact coal and not to charcoal.

It is not always possible to obtain a good horizontal cleavage in any or every desired horizontal plane of any coal. Some coals split much better than others; the more compact the coal the greater the difficulty in obtaining a good split. The Pittsburgh coal proved the most difficult to split in any desired lamina, whereas the coal from the Vandalia mine near Terre Haute, Ind., although very com. 
pact, splits with comparative ease; however, with some care and by using a small block, enough cleavage faces for satisfactory observations may be had from any coal. In the more compact parts of a block the fracture will often run across the anthraxylon components and thus fail to give a full exposure of all of them. This condition is shown in Plate XXXIV, A, from the Ziegler coal, which is typical of such fractures. The dark, irregular, heavy black lines or areas represent the oblique or more or less vertical fractures across the anthraxylous laminae.

\section{STRUCTURE OF THE VANDALIA COAL.}

The Vandalia coal splits with a clean, smooth surface in which certain characteristics are distinctly exposed and sharply defined. It is therefore remarkably well adapted for examination and photography for this purpose and may well serve to illustrate a general condition in coal. Plates XXV and XXVI, magnified twice the natural size, are taken from cleavage surfaces of horizontal fractures through the lump of coal shown in Plate CXLII, at the levels $\mathrm{x} \times$ and $y \mathrm{y}$, where the lump is compact.

On these surfaces are certain areas or patches showing woody structure and other areas, partly or wholly surrounding the former, that are practically structureless. The former look like small chips of wood or impressions of such chips embedded helter-skelter in a structureless mass. Some of the patches are isodiametric, others are long and slender, some have straight edges and sharp corners, others are rounded or irregular, and some look like mere slivers, being long, slender and sharp pointed. In general the grain of the wood is clearly seen.

The most characteristic feature is that the patches are all relatively small, as shown in the photographs. As the fractures are generally clean cut and the whole patch is exposed, the photographs present accurately their relative sizes (twice natural size) and general appearance. $\mathbf{A}$ slight difference in the general form and also in the sizes of the patches with woody structures will be noticed in the two surfaces.

Fine "rodlets" or "needles" may be recognized scattered over these clearage surfaces. Some of them lie helter-skelter in the structureless areas; others are in the woody patches and evidently form a part of them. Remnants of cuticles may also be obserred in some of the structureless areas.

\section{STRUCTURE OF THE BENTON AND HART-WILLIAMS COALS.}

The features so clearly seen in the Vandalia coal are repeated in the group of coals from the No. 6 bed of Illinois, though not in so clear 
and convincing a manner. Wherever a cleavage is made through the dull laminæ, the surfaces exposed consist of similar patches of woody structure and structureless areas, together with a sprinkling of the so-called needles or rodlets, and occasionally a patch of charcoal. A larger structureless area, such as is shown in Plate XXXIV, $B$, is rarely seen.

Plate XXVII represents, in a little more than natural size, the cleavage surface through a compact layer of a piece of coal from the Benton mine. The structure of the woody patches may be seen distinctly. The patches cover the surface almost completely, as the fracture contains but few small structureless areas.

Plate XXVIII, $A$, represents a cleavage surface, at natural size, made a little obliquely through the block represented in Plate XI, $A$ and $B$, at $\mathrm{x}, \mathrm{y}, \mathrm{z}$ (fracture 1). Nlthough this surface has a larger total area of structureless patches and a large number of fine needles, the woody patches are seattered over the whole of it. Plate XXVIII, $B$, shows a cleavage surface in the same block at the level $\mathbf{t}, \mathrm{u}, \mathrm{v}$, also somewhat obliquely across the bedding planes (fracture 2). The structureless area occupies about one-half of the total area, the woody patches lying somewhat like islets in it. The alternating layers are clearly brought out by the oblique fracturing and show better than anything else that woody patches are present throughout the coal. On the corner area at u the fracture runs through a thicker piece of bright coal or anthraxylon.

Plate XXIX represents fracture surfaces of the Hart-Williams coal. In the upper fracture the surface consists on the whole of woody patches. In the lower one the fracture runs mainly through a thicker piece of bright coal, showing, as do other fracture surfaces, the jetty inner appearance. The cell structure also may invariably be recognized in such a fracture.

\section{STRUCTURE OF THE COAL FROM SESSER, ILLINOIS.}

Plate XXX represents the clearage surface through a piece of coal from the Sesser mine at Sesser, Ill. In this coal the same structure occurs. The many black irregular areas show where the fracture cuts through smaller pieces of bright coal; that is, through the interior of the woody patches.

\section{STRUCTURE OF THE BUXTON COAL.}

The Buxton coal in many respects has lignitic characteristics, and a study of its cleavage surfaces is of particular interest.

Its general appearance as seen in Plates XXXI to XXXIII, at low magnifications, are similar to the other coals. Besides the woody matter, a considerable amount of cuticle is exposed to the surface, as 
is particularly noticeable in Plate XXXIII. The woody patches as in the other coals, are relatively small and have about the same shape and outline, but the cell structure is not so well defined, probably on account of the advanced decay of the woody element before coalification. However, enough of the structure is preserved to show a large-celled structure. In the woody patches themselves, as well as in the attritus surrounding the patches, numerous "rodlets" or "needle-like" bodies may be observed, as shown in Plate XXXII. (See the chapter on "Rodlets," p. 78.)

\section{UNUSUAL STRUCTURE.}

The horizontal fractures so far cited represent the usual or common structure. Some planes expose unusual features; although these differ much from the ordinary, they may be seen in any Paleozoic coal. Plate XXXV, $A$ and $B$, show parts of a horizontal fracture, from the coal from Royalton, Ill., through a block containing a lamina similar to that shown in Plate XXII, A, along the horizon 3-r. In these surfaces are exposed a number of "rodlets," parts of petioles, bits of woody tissues, cuticles, and objects that resemble "rodlets," embedded in the attritus. (See chapter on "Rodlets," p. 78.) Similar surfaces are found that expose a large number of very slender rodlets instead of the thicker ones shown.

A large surface in which no woody patches and rodlets are exposed is very rare. Plate XXXIV, $B$, magnified ten times, shows a surface through layers of fine débris exposing an exceptionally small amount of woody structure. A few of the so-called rodlets are also seen.

\section{SIMILARITY OF HORIZONTAL CLEAVAGES OF ALL COALS.}

The nature of the horizontal cleavage surface has been shown to be similar in all coals examined. Many cleavage surfaces from different coals have been examined, and the structure is similar no matter where the cleavage is obtained in the compact coal of any ordinary bituminous coal, nor from what seam. Attention is called to the fact that cleavage surfaces in the compact coals only are mentioned and not those representing the so-called mineral charcoal or "mother coal."

The conclusion is that the cleavage surfaces in the compact coal of all ordinary Paleozoic coals are similar in character.

\section{CORRELATION OF THE VERTICAL SECTIONS AND HORIZONTAL CLEAVAGES.}

\section{NATURE OF THE WOODY PATCHES.}

The question arises as to whether the woody patches invariably seen on the horizontal cleavage surfaces are actual pieces of woody 
coal or merely the impressions of woody structure and, if the former, are they the same woody components seen in the cross sections of the coal or something else.

On examination these patches are found to be very thin pieces of anthraxylon embedded in a finely divided ground mass or attritus and lying horizontally in every conceivable direction. The coal is largely composed of such pieces. Often they are so thin that a few scratches with a sharp-pointed tool, as a pair of forceps, will cut through one chip and expose another one beneath, sometimes with fibers running in another direction. Some patches are thicker, especially the larger ones, although their thickness is not always proportionate to their breadth and width. Some of the larger ones may be thin, and some of the smaller ones may be relatively thick, but as a general rule all are very thin. The woody patches that occur universally in the ordinary bituminous coals therefore are components and not impressions of objects that have disappeared.

These woody components are always present, no matter where a horizontal cleavage is obtained. In the cross sections, also, of any piece of coal the woody or anthraxylon components are seen to make up a large, usually the larger, part of the coal. The inference is that the patches are identical in both sections and cleavages. A close examination proves that they are in fact identical components, and also that the cell structures seen in a cleavage surface are not merely the impressions of some structure but are actually the fibers of pieces of woody coal.

\section{ORIGIN OF THE WOODY PATCHES.}

The origin as well as the nature of the woody components is shown to be analagous to similar components in peat. Comparisons of the general appearance of coal and peat in this respect establishes a proof of the origin of the woody patches in coal, and aids in obtaining a more comprehensive idea of the woody components and their appearance in horizontal surfaces.

\section{SIMILARITY BETWEEN HORIZONTAL CLEAVAGE SURFACES OF COAL AND PEAT: A PROOF BY ANALOGY.}

\section{EXAMINATION OF SURFACES.}

If a sufficient amount of well-matured peat is removed from a woody Wisconsin peat swamp, care being taken that its original and natural arrangement is not disturbed, and it is dried slowly until the mass hardens, the lump will be laminated similarly to coal, except that the layering will not be so definite, because the peat has not been greatly compressed. Often a lump of peat may be split horizontally along certain planes or bedding layers with a smooth, $125536^{\circ}-20-$ Bull. 117-4 
clean-cut surface. When such a horizontal surface is examined macroscopically or with a binocular microscope, the constituents present may be readily observed. A number of thin flat chips of wood parallel to the bedding, the origin of which was discussed in a previous chapter, and a few thicker ones, are characteristic in this surface, and deserve special attention.

The series of Plates IV to VI were prepared from horizontal surfaces of peat. A casual comparison of these with the horizontal cleayage surfaces of coal shows a close resemblance, although the plants that contributed to peat differed in kind and organization, if not in cell structure, from those that contributed to coal. In the surfaces of both are seen the characteristic thin flat chips of woody components, the narrower slivers and thicker pieces, cuticles of leaves, occasionally parts of leaves themselves, and here and there parts of petioles and bits of stems or rootlets, all embedded in the general attritus. Instead of seeds or seed coats, the coal contains sporangia and megaspore exines. No equivalent in peat has been discovered for the rodlets in coal. The closest resemblance to peat is seen in the cleavage surfaces of the coal from Buxton, Iowa (Pls. XXXI-XXXIII and Pl. CXXIII), which is a low-grade coal and has retained lignitic characteristics.

\section{DISSECTION OF HORIZONTAI CLEAVAGES.}

Proof that the woody patches seen in the horizontal fractures are identical with the woody components seen in the rertical sections may be obtained directly in several ways. The method of selecting a small block of coal with a smooth vertical edge and splitting it in any desired lamina with a sharp knife, under the binocular microscope, is the most reliable. A piece of compact coal will not always split in the desired plane, but enough cleavage planes can be obtained in any desired lamina to obtain conclusive results. Some coals split much more easily than others; as already stated the coal irom the Pittsburgh bed was the most difficult to split along any given horizontal cleavage plane, and the Vandalia coal was the easiest. Another method is maceration by means of Schulze's reagent, when not used in solutions too strong. After long treatment in a weak solution of Schulze's reagent most coals come apart in very thin laminæ or sheets, so that the woody or anthraxylon components may be lifted out with a pair. of fine forceps or needles. In this way layers of considerable thickness may be dissected. Therefore, no doubt remains that the woody or anthraxylon components seen in cross sections and those seen in the horizontal cleavage surfaces are identical.

However; to remove all doubt, the origin of the patches in small pieces of wood or other plant tissues will be conclusively shown. 
Thin sections and microscopic examination at high magnifications are required for this proof.

\section{MICROSCOPIC EXAMIN.ATION OF COAL.}

\section{STANDARDS OF COMPARISON.}

In order to obtain a correct idlea of the relative sizes of the actual and magnified sections standards of comparison are necessary. Without these, the illustrations at higher magnifications give an inadequate idea of the actual size of the objects or of the area of the coal section represented. This is particularly true of magnifications at 200 diameters and over. At a magnification of 1,000 diameters and more a concept of the actual size of the object or area represented is entirely lacking. without some stamlard of comparison, even in persons who are familiar with microscopic examinations. A correct idea of the size of an area represented at a mannification of 10 diameters is comparatively easy if the fact that the dimensions of the original are one-tenth of those of the photograph is borne in mind. If, for example, a photograph represented at a magnification of 10 diameters measures 5 by 7 inches, the area of the coal section represented measures 0.5 by 0.7 inch. But if the magnification of a certain object or area is 200 diameters, the actual size of the original area represented in the photograph is far more difficult to comprehend. If the photograph measures 4 by $:$ inches. which is a little larger than most of the photographs presented, then the area of the original coal rection represented in that photograph is only $1 / 50$ by $1 / 40$ of an inch. As the majority of the photographs at a magnitication of 200 diameters measure approximately 100 by 120 millimeters, the millimeter is a more commensurate and convenient unit, and such photographs represent an original area of 0.5 by $0.6 \mathrm{~mm}$. The dots and periods used in the printing of this bulletin are approximately $0.5 \mathrm{~mm}$. in diameter and are a convenient standard for comparison.

When areas are magnified 1,000 diameters a satisfactory standard is almost impossible. The dimensions of the original object or area represented are so small that the millimeter becomes an inconvenient unit and the micron-a microscopic unit, the 1/1000 part of a millimeter-is used instead. At a magnification of 1,000 diameters, any circular area measuring $100 \mathrm{~mm}$., or about $t$ inches in diameter, represents an original area 100 microns in diameter. The average diameter of a hair from the human scalp is about one-half of that, or 50 microns. Yet a strip of coal section the thickness of a hair contains a great many objects, as is seen in the illustrations. A hair, then, may be considered a convenicnt standard, remembering that the average thickness is about 50 microns, or $1 / 20$ of a millimeter. or $1 / .000$ of an inch. 
Obviously, extensive areas from a coal section, or larger areas of the sections shown at 10 diameters can not be represented at a magnification of 200 and still less at 1,000 diameters. This may suggest that an adequate idea of the nature of larger sections of coals is not obtained through illustrations representing a small area; experience has shown, howerer, that many layers of coal are so similar in appearance and composition that photographs taken at certain intervals and showing certain characteristics, give a fair representation of a larger piece of coal or eren of the whole bed.

\section{CORRELATION OF CHARACTERS.}

Before discussing the detailed examination of the coal sections at a highèr magnification it will be necessary to correlate the appearance of the features seen in opaque sections or polished surfaces cut vertically to the bedding planes and examined by oblique illumination, with the same features as seen in thin sections examined by transmitted light at the same magnification, or at a slightly higher magnification.

\section{COAL FROM THE PITTSBURGH SEAM.}

Compare the opaque cross sections of the coal from the Oak mine in the Pittsburgh bed, Plates XXXVII-XLI, already mentioned, with the illustrations of sections, from the same samples and horizons, prepared from thin sections by means of transmitted light, Plate XXXVII with Plate XLIV, $A$ and $B$; Plate XXXVIII with Plate XLV, $A$ and $B$; Plate XXXIX with Plate XLVI, $A$ and $B$; Plate XL with Plate XLVII, $A$ and $B$; Plate XLI with Plate XLVIII, $A$.

In the former illustrations the attritus appears as gray or white laminæ intercalated by darker striæ of anthraxylon. In the latter illustrations the anthraxylon appears as lighter, homogenous strips, and the attritus as the darker portions with a sprinkling or mottling of lighter inclusions. The order is, therefore, partly reversed.

The object of these latter illustrations is to serve as a steppingstone from the lower to the higher magnifications, and to convey a more accurate concept of the proportion, arrangement, and relationship of the anthraxylon to the attritus utterly impossible to obtain from the illustrations at higher magnifications. A close study of the illustrations at low magnifications and those of coal in the block is essential for this purpose. On the other hand, many details can be seen only in illustrations at higher magnifications.

Compare Plate XLIV, $A$ and $B$, magnified 10 and 20 times, respectively, with Plate XLVIII, $B$, magnified 200 times, both prepared from the same section although not from the same areas in the 
section, representing areas of "dull coal." The two lighter areas 1-a and 3-a (Pl. XLVIII, $B$ ), correspond to the lighter strips seen in Plate XLIV, $A$ and $B$, but more highly magnified, and the two darker areas, $2-\mathrm{d}$ and $4-\mathrm{d}$, correspond to the darker portions interlined by the lighter strips more highly magnified. The lighter parts, 1-a and $3-\mathrm{a}$, show plant or woody structure, with characteristic resinous inclusions, and are anthraxylon; the darker areas plainly are a conglomeration of various microscopic bodies defined later, and are the attritus.

Plates XLIX, $A$ and XLIX, $B$ (magnified 200 times), are more highly magnified areas included in Plate XLIV, $A$. Plate XLIX, $A$, represents a number of thin anthraxylon components closely piled one on the other. 1-r is a resinous layer, the cell walls of the tissue that once contained the resinous matter having largely disappeared. The area $2-\mathrm{a}$ is a continuation of the resinous anthroxylon; the cell walls have been very much flattened and closely pressed together, so that they are barely recognizable; $3-\mathrm{a}$ is a strip in which the structure is better preserved with resinous and cuticular inclusions; $4-\mathbf{a}$ is a strip of numerous thin anthraxylon components. Below this, at 5-d, is a strip of carbonaceous attritus including spore-exines and resinous bodies; and at 6-a is a thin anthraxylous strip in which the cell structure is faintly visible.

Plate XLIX, $B$ (magnified 200 times), represents a more resinous débris in the section shown in Plate XLIV, $A ; 1-d$ is a sheet of attritus composed chiefly of resinous particles represented by larger oval bodies; more or less irregular small narrow patches of humic matter in gray that are spore-exines; and a dark groundmass consisting of earthy and carbonaceous matter. The strips 2-a and 4-a are thin pieces of anthraxylon. Included between the latter is $3-d$, a lamina of attritus containing a large proportion of matter derived from cellulosic plant substances, which are dark red in the section and hence photograph black. In 5-a, a lamina of attritus, very thin anthraxylon strips, and several carbonaceous bodies are included; 6-a is a resinous anthraxylous strip; and $7-\mathrm{a}$ is attritus containing a large proportion of matter derived from woody products which we shall term humic, as well as the resinous matter, earthy matter, and exines, such as are in the other layers of attritus.

Plate LII, A (magnified 200 times), shows a more highly magnified area included in the upper anthraxylous part of Plate XLV, $A$ (magnified 10 times), with which it should be compared. Although it represents an anthraxylon area, it is readily seen to be composed of several laminæ. The anthraxylon laminæ 1-a, 3-a, and 6-a, alternate with the laminæ of attritus 2-d, and 4-d. The heavy double white lines at 5-c represent cuticles. The lower part of the section is also composed of alternating thin strips of attritus and 
anthraxylon; the strip at 7-d being a humic attritus. The cell structure, although recognizable in most parts of the anthraxylon components, is on the whole not clearly distinguishable, except under the microscope where cell structure is easily distinguished in any section examined. At 6-a the remains of the special thickenings of the cells (the checkered part) are clearly shown.

Plate LII, $B$ (magnified 200 times), represents a more highly magnified area from the middle region of Plate XLV, $A$. This area is composed largely of attritus, including numerous anthraxylon strips. The larger darker patches, particularly noticeable at the level 2-d, represents more highly carbonized particles, dark red under the microscope. (See chapter on Carbonaceous matter, p. 76.)

Plate LIII, $A$, represents a more highly magnified area in the lower part of Plate XLIV, $A$. The two strips 1-a and 3-a represent thin strips of anthraxylon, the small, white, irregular patches represent for the most part spore-exines, the gray areas represent cellulosic decomposition products, and the black represent the more highly carbonized particles.

Plate LIII, $B$, is an area in Plate LIII, $A$, magnified 1,000 times. The spore-exines, shown in cross section in the latter, are shown here in better detail. The other components, chiefly of cellulosic decomposition products and carbonaceous particles, are underexposed and are not shown clearly, although under the microscope they show up very clearly as will be seen in other photographs.

Plate LV, $A$ and $B$ (magnified 200 times), represents areas in the section shown in Plate XLVI, $A$ (magnified 10 times).

Plate $\mathrm{LV}, A$, is mainly a woody layer, with a strip of attritus above and below it. The cell structure is clearly seen.

Plate $\mathrm{LV}, B$, shows more definitely the alternation of the anthraxylon with the attritus. The anthraxylon strips 1-a and 3-a correspond to the lighter strips or bands in Plate XLVI, $A$, and the darker areas of attritus, $2-d$ and $4-d$, correspond to the darker strips. The strip 2- $d$ contains a large proportion of carbonaceous matter, and 4-d contains much cellulosic degradation or humic matter, besides the relatively few spore-exines shown as small linear white patches, the resinous and carbonaceous matter, and a number of fine strips of anthraxylon.

With Plate XLVII, $A$ (magnified 10 times), compare Plate LVI, $A$ and $B$ (magnified 200 times), prepared from the same section. In Plate XLVII, $A$, as in the other illustrations of this series, the lighter homogeneous parts represent the anthraxylon and the darker or more or less mottled parts represent the attritus, the anthraxylon constituting the larger proportion. In Plate LVI, $A, 2-\mathrm{a}, 4-\mathrm{a}$, and 5-a, corresponding to the lighter bands, distinctly show cell structure, and hence are anthraxylon components. Between these are 
lodged laminæ of attritus corresponding to the darker striæ of Plate XLVII, $A$, composed of various microscopic bodies. Plate $\mathrm{LVI}, B$, represents a woody area in which the cell structure is also very well recognizable. The part designated by 1 -ad represents a humic attritus, including a number of anthraxylon strips, the cell structure of which is faintly recognizable.

\section{THE BUXTON COAL.}

A comparison of the illustrations of Buxton coal at low and high magnifications is of value and interest. Compare Plate CXXI, $B$, prepared from an opaque section of "dull coal" by reflected light, with Plate (XXI, 1 , prepared from a thin section from the same specimen and photographed by means of transmitted light, at the same magnification, the one being the mirror image of the other. The corresponding components may easily be recognized in the two plates. At 1-d is an anthraxylous attritus with a sprinkling of spore-exines, at 2-s are included a number of sporangia filled with spores. Detailed illustrations of a similar sporangium, at higher magnifications are shown in Plates CXXXIII and CXXXIV. At $3-a$ is anthraxylon; below it, at $4-s p$ is a layer of attritus including a number of megaspore-exines and at $5-c$ is part of a cuticle. At 7-a is an anthraxylon layer. With these also compare Plate CXXII, $A$, in which the same kind of components may be recognized. These illustrations should now be compared with the series at 200 and 1,000 diameters taken from the section represented in Plate CXXI, $A$, and others from the same coal, which show the nature of the coal and the components in detail.

\section{THE VANDALIA COAL.}

Compare Plate CXIIII, $A$ and $B$, prepared from thin sections at a magnification of about 10 diameters, with the series (Plates CXLVI-(L) at higher magnifications, showing the nature of the component of the Vandalia coal in detail. As has already been shown, the coal from the Vandalia mine is made up of numerous thin, flat, wooly or anthraxylon components interlayered with a comparatively small amount of attritus. Compare these also with Plates CXLIV and CXLV, $A$ and $\boldsymbol{B}$, representing a horizontal cleavage plane from the same coal.

\section{THE COMPONENTS EXAMINED AT HIGHER MAGNIFICATIONS.}

Sufficient proof has been furnished that the so-called bright coal, glanz coal, humus coal, jet coal, bright laminæ, or by what other name it may have been called, represents inclusions of individual components of coal that at one time were larger pieces of wood or 
parts of stems or logs. Sufficient proof has also been furnished that the so-called dull coal, matt coal, or canneloid coal, consists of a general débris composed for the most part of small components of greatly varying sizes-at one time small particles or chips of wood-embedded in a mass of microscopic matter, termed attritus, which is derived from a variety of plant parts or plant organs. These kinds of coal, and their components are now presented in detail. Attention is called again to the fact that the woody or anthraxylon components, no matter of what magnitude, were at one time definite fragments, or units, and although they may seem intimately united with one another, or intimately packed or embedded in macerated matter in the coal, they are definite units or components.

\section{THE BRIGHT COAL OR THE LARGER ANTHRAXYLON COMPONENTS.}

\section{VERTICAL SECTIONS.}

Thin sections have been prepared and examined from many of the thicker anthraxylon components, of all the coals of the present series. In every section examined the anthraxylon components were seen to be derived from the woody part of some plant, of which the cell structure, or the wood fibers were in so fair a state of preservation as to leave no doubt of their origin and identity. In some sections this structure was almost as well preserved as in sound wood, except that the cells or fibers had collapsed as shown in Plate CII, $B$, and CVII, $A$ and $B$; in others very careful observation was required to see the structure. (Pl. XCI, $A$ and Pl. XCIII, $B ; 1-$ a.) Between these two extremes all possible intergrades of preservation were found, but in no section had the structure been so far effaced as to be unrecognizable. The state of preservation is never the same throughout the section, as can readily be seen from a study of the photographs; in some parts the cells are almost completely preserved, whereas a little distance away the structure is recognizable only faintly.

Occasional cells or fibers have retained their original form and arrangement quite well, although the walls have been pressed together and the lumina have disappeared, as shown in Plate CVII, A, taken from the Royalton coal; often the arrangements of the fibers is much disturbed, although preservation of their form is good, as shown in Plate CII, $B$, taken from the coal from Sesser, Ill. In other sections the fibers are so flattened as to be very thin and rather broad, this probably being the most common condition. (See Pl. XCII, $A$ and $B$, from the Ziegler coal.) Some of the walls have become very thin and are intimately united so that the individual cells are recognized with great difficulty, as seen in the 
nthraxylon strips shown in Plate XCIII, $B$, taken from the Ziegler sal, and Plate CXLVI, $A$, taken from the Vandaiia coal, a condition articularly common in the latter. Plate CI, $A$, taken from the al from Sesser, Ill., and Plate (XIV, A, from the Shelbyille coal. represent structures that contain a varying amount of ssinous matter in the lumina of the fibers, common in every coal xamined. These resinous contents having retained more or less of acir original volume and shape, have kept the cell walls distended to ae extent of their volume. The walls themselves show the same ffect of decay as in other sections, as is shown in the places where ue resinous contents are absent or scarce. (Pl. CI, $B$; Pl. CII, $A$; nd P'l. CXIY, B.)

\section{HORIZGNTAL SECTIONS.}

The plant structure is particularly well shown in sections cut arallel to the bediling planes. The reader has become a ware, through ie examination of the sections cut perpendicularly to the bedding lanes, that all the plant cells and filsers hare been compressed and attened. and that the cells and filers thus flattened lie roughly arallel to the bedding. Therefore, when an anthraxylon component ; cut parallel to the bedding plane, all cells lying in that plane are xposed on their broad sides, and if any cell characters are present, ach as bordered pits, spiral, trabecular, and scalariform thickenings, hey are likewise exposed for examination on their broad side. Also, he original nature of the tissues, such as the xylon strinds separated $y$ cortex, rascular strands in the cortex, rays, and even leaf traces, lay be detected. Thus much of the anatomy of the plants contribting to the coal may be seen.

\section{PRESERVATION OF STRUCTURE.}

Some part of a coal bed contains more anthraxylon coal with better reserved cell structure than others, and some coal bed; contain more f the better preserved anthraxylon components than others. For sample. of the coals examined that from Carbon Hill, Ala., contains ie most and the best preserved plant structure.

The coal of the Pittsburgh bed seemingly ranks next, but its strucrre and cell preservation differ in various localities and at different orizons in the bed. The coal from the experimental mine, Bruceton, 'a., has revealed the most and the best preserved structure and that rom Marlison, Pa., the least of all the coals examined in this seam. At one place in the bed the structure of different layers may vary. the Oak mine, for example, the cell structure is better preserved the top than at the bottom. The same is true of the structure of smaller components, as a close examination of the illustrations the coals from that mine will show. 
The coal from the Vandalia mine, near Terre Haute, Ind., the most anthraxylous of all the coals examined, has retained the least plant structure. This coal reveals an abundance of structure quite difficult to see in certain parts of some cross sections, but easily ob servable in horizontal sections in the anthraxylon matter.

As woody structure has been seen in all coals examined there can be no doubt that almost all of that portion in coal that has been termed "bright coal," "glanz coal," or "jet coal" is derived from components that at one time were pieces of wood. What kind of wood or what kind of trees they represent does not concern this report any more than how large a part of a certain tree, stem or branch any of the components represents, for there was no opportunity to study this comprehensively.

\section{THE “DULL COAL."}

In preceding chapters the "dull coal" has been shown to consist largely of smaller anthraxylon components embedded in a mass or matrix composed of more finely divided plant matter called the attritus. The "dull coal" may conveniently be classified into twe main subclasses-the small' " anthraxlyon components and their embedding matrix, the attritus.

THE SMALLER ANTHRAXYLON COMPONENTS.

The appearance of the smaller anthraxylon constituents in the block and in the section at low magnifications has already beer pointed out. Their appearances at low and at high magnification have been correlated. The anthraxylon inclusions seen in cross sec tions and the patches usually showing a woody structure seen ir horizontal cleavage fractures nave been shown to be identical Through a correlation of the cross sections and the horizontal frac tures the form, thickness and sizes of the anthraxylon parts hav been learned, as well as their distribution and the proportion of thei mass to that of the other components. Their origin and mode o formation have been indicated through analogous formations ir peat. Their structure and appearance at higher magnification remain to be shown. The anthraxylon components differ greatly ir size, ranging down to microscopic bits.

SIZE AND FORM.

To obtain a correct idea of the relative as well as the actual thick ness of the anthraxylon components, the reader should study care fully all the photographs prepared from opaque sections at a lov magnification with those prepared at low magnifications from thin sections by means of transmitted light. The latter are of particula interest in connection with this study and should be correlated witl 
the appearance of the coal in horizontal cleavage surfaces. Plates XLIV to XLVII and Plate XLVIII, $A$ (magnified 10.times) give an excellent idea of the relative thickness, arrangement and mode of compilation in most of the ordinary coals. Plate CXLIII, $A$ and $B$, is a good representation of a very anthraxylous coal. With these should be correlated the photographs at higher magnifications. (Pls. XLIX-LIX and PI. CXLVI, $A$ and $B$.)

Plate XLVIII, $B$, prepared from the same sections as Plate XLIV, $A$ and $B$, gives a definite idea of the thickness of some of the anthraxylon components. The relatively thick band 3-a, running lengthwise through Plate XLVIII, $B$, is approximately $32 \mathrm{~mm}$. thick in the photograph, and therefore was actually only a very little more than one-sixth of a millimeter; $1-\mathrm{a}$ and $3-\mathrm{a}$ in Plate $\mathrm{LV}, B$, both relatively thick pieces, were only one-tenth and one-fortieth of a millimeter thick. In the same photograph at 4 -d several strips are embedded that were only about one one-hundredth $\mathrm{mm}$. thick. Similarly the strips in photographs representing coals from other localities in the Pittsburgh bed, as, for example, Plates LXIII to LXVI, and Plate LXIX, $A$, some of which show their cell structure clearly, are extremely thin, but nevertheless they were at one time chips of wood similar to those found in the peat of to-day.

The reader can calculate for himself the actual thickness of any of the anthraxylon strips represented by measuring the thickness of the strip in the photographs prepared from the cross sections of any coal and dividing that measurement by 200 for photographs at a magnification of 200 and by 1,000 for those at a magnification of 1,000. The study of the photographs of horizontal cleavage surfaces, together with those of cross sections at a low magnification, gives a better idea of the actual width and length of the anthraxylon components.

A considerable part of the anthraxylon matter is chopped up or granulated, although much of this has also been flattened and some is angular and more or less isodiametric. This form consists of extremely small particles varying from colloidal size to whole cells and is a part of the attritus called humic matter. The proportion of this class of anthraxylon or humic matter varies from layer to layer, and from bed to bed as shown in LI, $A$ and $B$; LII, $B$; LIV, $B$; LV, $B$; LVIII, $A$; LXI, $A$ and $B$; LXII, $A$; LXIII; LXVI; LXVIII ; LXX, $A$ and $B$; LXXI, $A$; LXXII, $A$; LXXIV, $A$ and $B$; LXXVI, $A$ and $B$; LXXXIV; LXXXVI; LXXXVIII, $A$; LXXXIX, $A$; CIV, $A$; CIX, $A$ and $B$. It is better shown in sections cut horizontal to the bedding, and is discussed under the attritus as humic matter.

A comparatively small amount of anthraxylon matter is amorphous. From the standpoint of a microscopist there are, strictly 
speaking, no homogeneous substances found in organic substances in coal. Even the cell walls of the anthraxylon resolve into individual particles or micelli when examined by ultra-microscopic means. Anthraxylon or humic matter in this finely divided con dition is said to be homogeneous. Such matter sometimes forms the embedding medium of many kinds of finely divided particles, forming the groundmass, which has a granular and amorphous appearance. This phase is discussed in relationship of coal at high magnification, under the head of attritus.

DISTRIBUTION.

Although, in most coals, such as the Pittsburgh coals, the anthraxylon chips are embedded in an attritus, the pieces may be packed more or less immediately one on top of the other. This is true to a larger extent of the Illinois and Indiana coals examined. In the coal from the Vandalia mine, near Terre Haute, Ind. (Pl. CXLIII, $A$ and $B$ ), the larger part of the coal, by far, is composed of such chips lying lirectly one upon the other with comparatively little of the attritus interlayered between them.

COLOR AND TRANSPARENCY.

The color of the anthraxylon varies from dark red to light yellow in thin sections, depending on the thickness and transparency of the section. Other factors being equal the thinner the section, the lighter the color; the thicker the section, the deeper the color. Sections of equal thickness but from different samples from the same or different beds also vary in transparency; the more transparent, the lighter the color. and the less transparent, the darker the color, it ranges from a yellow to a deep red.

Of the coals examined, the anthraxylon of that from the Vandalia mine, near Terre Haute, Ind., is the most transparent, although different sections taken from the same coal may vary in this respect. That of the coal from the Zeigler mine is, in general, less transparent than those examined from the surrounding fields. The anthraxylon components from the Pittsburgh seam varies according to the locality from which they are taken. That from the experimental mine and from the Oak mine are relatirely transparent and light in color: that from Madison is considerably less transparent and of a deeper red color, while that from the Connellsville region is the least transparent and of a deep red color.

The transparency of anthraxylon depends on its carbon content. Roughly, the transparency of the coal varies inversely with the carbon contents. No anthraxylon components of the coals examined were absolutely opaque, and only a few were barely translucent in thin sections. 
The anthraxylon components may almost always be recognized adily by their color, and by their peculiar physical structure, due , the original cell structure of the material from which they are srmed. This is either definite cell structure, similar to that seen in ving plants, as seen in Plates XVI, $A$; LVII, $B$; LXVIII; LXIX, ; LXXXIV ; LXXXV; LXXXVII; and CXIV, $A$, or of fine lines ore or less parallel to each other, as seen best in Plates LVII, $A$ and ; LXIII ; LXIV ; LXV ; XCI, $B$; XCII, $A$ and $B$; XCIV, $A$; and IX, $A$ and $B$. These lines have resulted from the collapsed, comressed, and intimately united condition of the original cell walls of re plant from which they are derived. Between these two extremes Il possible states of preservation may be observed.

In the vertical sections the cell structure of the smaller chips sually does not seem to be so well preserved as in that of the larger ieces; however, many. strips are found in which the structure is bout as well preserved as in living plants. Examples are shown in 'lates LXIX, $A$; LXXXIV, LXXXV; and LXXXVII. Such reservation is by no means rare, yet considering the total anthraxlon mass, which constitutes by far the largest part of the coal, it is ne exception rather than the rule. Another very common peculiarity $f$ structure that is easily recognized is where the cell walls, although ollapsed, have retained a relatively large part of their original mass, nd have either been flattened out or variously folded and contorted. .his is not nearly so well preserved as in the previous examples. ;uch structure is shown in Plates XLVIII, $B$; LV, $A$ and LIX, $A$. Attention is called to the fact that the structure of the wood ibers can be shown distinctly only when cut more or less at right ngles to the fibers. When cut approximately parallel the strucure is not easily recognizable as it is normally so poorly preserved. 'late LVII, $B$, Plate LVIII, $A$ and $B$, and Plate C, $B$ show more ir less parallel sections. As the anthraxylon fibers lie in every coneivable horizontal direction, the chances are that only a small numer of the fibers are cut more or less at right angles in the vertical ections, and hence the majority, even if well preserved, will escape rotice, other good examples are shown in Plates LII, $A$; LV, $A, 3-\mathrm{a}$; IXIV; XCII, $B, 1-\mathrm{a}$.

The most common structure is that in which the original cells ave been so much flattened and pressed together that they are diffi:ult to recognize. Such structure may be seen in almost every secion from every coal examined. See many of the photographs representing anthraxylon coal, particularly those of the Zeigler, Buxton, and Vandalia coals. In a few photographs there appears at first sight to be no structure. An example is shown in Plate CIX, $A$ 
(magnified 200 times). But when such sections are put under higher magnifications with proper illumination the structure is clearly seen, as is shown in Plate CIX, $B$ (magnified 1,000 times), prepared from the same section as was Plate CIX, $A$. Plate CIV, $B$, and Plate CV, $A$, magnified 1,000 times and 200 times respectively, reveal the same fact. Again, in Plate LXXXIX, $A$, are several anthraxylon chips in which very little structure can be detected; but Plate LXXXIX, $B$. taken from the same area, but magnified 1,000 times, leaves no doubt as to the remaining cell structure. At low magnifications the Vandalia coal (Pls. CXLVI-CL) reveals very little cell structure in the anthraxylon components, but when the sections are examined under high power and proper illumination, the remaining structure is well shown. This is seen more decidedly in horizontal sections discussed later.

Frequently where the structure is not easily recognizable, the mass and the form of the cell have not been destroyed so much as the features or qualities that differentiate the cells from one another. The cell walls, or fiber walls, have been rendered more homogeneous during the processes of coal formation. The middle lamellæ having disappeared, the cell walls and the lumina, which have completely collapsed, have been so intimately united that the whole cell is a complex, seemingly homogeneous mass. The individual cell walls of such a homogeneous anthraxylon mass need not necessarily be thin, but may be of the same thickness as those more easily distinguishable. These cells can be distinguished only through specia] illumination, by taking advantage of the slight differences of the refraction of the different parts of the walls, or by means of polarized light, as each fiber or cell is optically active. These cells or fibers have not been obliterated, but the characteristics or qualities through which they are normally distinguishable, have been more or less removed.

STRUCTURE SEEN IN HORIZONTAI, SECTIONS.

The clearest evidence of the cell structure is obtained in horizonta: sections which not only verify the interpretations made from the vertical sections, but also amplify and bring out the characteristics in greater detail and clarity, and expose other characteristics that are not observable in the rertical sections.

The true nature of the larger and the thinner chips, such as arr characteristic of the horizontal cleavage surface, is disclosed, and alsc that of the scattered fibers or small complex of fibers and other comminuted plant matter. The nature of the original tissues may often be recognized distinctly. The structures or form of the cells and fibers, whether long, short, thin, thick, rounded, or isodiametric are plainly shown. The cell character, such as pittings and spira 
abecular and scalariform thickenings, rarely seen in the vertical ;ctions, is shown in almost every horizontal section. In some secons, as in Plate CXL, $A$ and $B$, remainders of the nuclei are pparently recognizable. Parts of plant organs, like sporangia, leaf aces, vascular strands, petioles, and other parts of leaves may be sserved, often in a remarkably good state of preservation.

The photographs prepared from horizontal sections are for the ost part self-explanatory, yet it may be well to call attention to ime of the principal features illustrated.

As the object of the photographs taken from the horizontal secons is to show some special characteristic rather than the anthraxlon chips and their structure, these photographs present, in the ain, parts of coal that lie between the chips, and most of them low only the edges or fringes or cut parts of the more solid iips. A relatively small anthraxylon chip magnified 200 diameters ould make a photograph many times the area of a page in this slletin. One of the characteristic chips or patches shown in Plate $\mathrm{XV}$, if only one-fourth inch, or about $6 \mathrm{~mm}$., square would if agnified 100 times cover a space of 25 inches square. Only a few : the photographs from horizontal sections are therefore wholly, or part, intended to illustrate solid woody components or chips.

Plate LXII, $A$, of the constituents of the attritus in horizontal secons shows on the lower right-hand corner a part of an anthraxylon ip in which the cell structure is well defined. Plate LXXIV, $A$, horizontal section from the coal of the experimental mine, magnisd 150 diameters, shows the anthraxylon matter in a rather cominuted condition and consisting mainly of separated fibers and cells. Plate LXXIII, B, shows, besides the part of a sporangium in the iddle, much anthraxylon matter in which the structure is also early shown, particularly in the lower part. Plate LXXI reprents much of the anthraxylon matter in a comminuted condition, but so parts of the more solid chips that have retained some of the iginal structure in fairly good condition. Plate LXXII, $A$, reprents a strip of anthraxylon embedded in the attritus in which the iral thickenings of the wood fibers are still recognizable. In Plate XXII, $B$, the section cuts obliquely through overlapping anthraxon chips containing spiral vessels. A leaf-trace, in which the remains

spiral vessels are clearly seen, lies between the two. The cell aracters of the piece in the lower right-hand part of the photoaph are shown, also the cells of the piece represented in the leftind part of the photograph are cut diagonally, and are not so ear as the former. In the extreme upper part another chip is seen ith scalariform thickenings. On the right-hand side of Plate CIX, $B$, from the Zeigler coal, is shown part of a solid, narrow- 
fibered chip without cell thickenings. Through this section of tl chip may be seen the general débris lying under it. The componen of the dèbris or parts of other chips are commonly seen under a anthraxylon chip, showing how exceedingly thin these chips may $b$

Plate CXL, $A$ and $B$, and Plate CXLI, $A$, from the Sipsey coa show horizontal sections of a tissue in which the cells are remarkab. well preserved. The cells seem to have been more or less isodiametri and the structures within them very strongly resemble nuclei. The would certainly be called nuclei if seen in a section from a livir. plant; not only that, but the darker granules seen in the nuclei-lil structures would also be called chromosomes. Whether they a] actually remains of the nuclei and their chromosomes must remai an open question, as the preservation of such delicate cell par seems doubtful. Detection of many similar objects are necessar for a positive decision.

Plate CXLI, $A$, shows tissues with large isodiametric cells in tl lower part, and large fibers with multiseriate bordered pits, chara teristic of the Cycadofilicales and common in many coals.

Plate CXXVIII, $A$ and $B$, represents parts of an anthraxylon chj from the Buxton coal. Although the chip is not well preserved, tl structure of the tissue is distinct. The diameters of all the cells a] large. In the section may be seen a series of large tracheæ wit bordered pits, separated by short parenchymatous cells, which sho vaguely in the photograph. These and other features leave no doul that the tissue is derived from one of the Sphenophyllæ. In tl Buxton coal.the woody structures are difficult to detect in cross se tions, but an examination of the photographs just mentioned leav no doubt that the Buxton coal has retained its share of woody stru ture, though this is not so well preserved as in most coals.

In the coal from the Vandalia mine, the woody structure is pr served the least, and examination through cross sections alone wou] lead to the conclusion that very little structure remained. But whe this coal is examined in horizontal sections, an abundance of structu] is seen to have persisted, although it is rather poorly preserve A horizontal section of coal from the Vandalia mine when viewe at a low magnification, as shown in Plate CXLIV, $A$ and $B$, leavi no doubt as to the presence of much woody structure. This is muc more clearly shown at higher magnifications, as in Plate CXL $A$ and $B$, in which both scattered as well as solid tissues appea Although the cell structure of this coal is poorly preserved, suc characters as spiral and scalariform thickenings are not rare in th horizontal thin sections.

REDUCTION IN THICKNESS FROM THE ORIGINAL OF THE ANTHRAXYLON.

A general estimate of the reduction in thickness of the woody con ponents in coal is difficult to obtain, because usually the fibers are ne 
easy to distinguish from one another when they have been much compressed and intimately united, and because the amount of reduction in thickness varies greatly in the same piece as well as in different pieces. However, in many sections definite counts and measurements can be made.

The amount of reduction in thickness may be realized in examining thin horizontal sections in which frequently several fibers may be seen lying one above the other, all in focus at a low magnification. In focusing up and down under a high magnification a number of fibers may be recognized in a comparatively small space. These must have been compressed a great deal. Many components, however, have retained half or more of their original thickness.

Counts madé in a thin section from the Ziegler coal at a magnification of approximately 1,000 diameters gave 40 lines per 50 microns in an anthraxylon lamina 500 microns or $0.5 \mathrm{~mm}$. thick. Assuming that every line under observation represents a woody fiber, the whole piece would have 400 fibers one above the other, or 800 cells to the millimeter. Assuming that the average diameter of the cell originally was 50 microns, the original thickness of the chip would have been $20 \mathrm{~mm}$. This piece in question, therefore, suffered a reduction to one-fortieth of its original thickness. This is an extremely large reduction, although by no means uncommon.

Plate CII, $B$, represents part of a thick anthraxylon component from the Sesser coal containing approximately 240 cells to the millimeter. A few well-preserved cells remaining in it have an average diameter of 25 microns. Assuming this to be the average original diameter of the cells of the piece in question, it would have suffered a reduction to only one-sixth of the original thickness. Structures in the state of preservation as shown in Plate CII, $B$, are common. This reduction in thickness does not indicate a loss in the mass in the same proportion, because the collapse of the cell walls alone-that is, the removal of the air space of the lumina-will account for a large part of the reduction, the amount depending on the size of the lumina or, in other words, on the thickness of the walls. The cells in the anthraxylon piece in Plate CVII, $A$, from the Royalton coal, have been compressed to not more than one-half of their original thickness in the upper part of the photograph at 1-a to 3-a. In the lower part of the photograph, at 4-a, they are reduced considerably more. An average of 175 cells to the millimeter for the lower part compared to 80 cells to the millimeter in the upper part was estimated. The reduction of the cells in the lower part has therefore been to between one-fourth to one-fifth of their original thickness, the average diameter of the fibers being 25 microns. Most of the cells of this large anthraxylon component are in the state of preservation shown in the lower part of the photo$125536^{\circ}-20-$ Bull. $117-5$ 
graph, an average condition of all the larger anthraxylon components in this coal. The smaller fragments as a rule have been reduced much more in thickness than the larger ones, but not to less than one-fortieth of the original thickness.

In the coal from the Pittsburgh bed the cells, in general, have been reduced more toward the top than at the bottom of the bed. An average anthraxylon component approximately $0.2 \mathrm{~mm}$. thick, and hence one of the thinner chips, was found cut squarely across the grain and hence suitable for making counts. The average number of cells one above the other in this piece was 50 , hence there were 250 cells to the millimeter of coal. The original diameter of the cells according to various measurements and estimates can not have been over 50 microns $(0.05 \mathrm{~mm}$.) nor much less, 50 microns being probably very nearly the average diameter of the original cell. On the assumption that the original diameter was 50 microns, the original thickness of the piece in question would have been $2.5 \mathrm{~mm}$., a reduction in thickness therefor of $12 \frac{1}{4}$ to 1 . In this piece the cell walls can not have lost much of their original thickness or mass.

Plate LIX, $B$, from the Oak mine, shows a type of wood and a mode of preservation common not only in this coal but in all coals examined. The average number of cells to the millimeter is 368. The average diameter of the cells of this type is about 30 microns. The reduction in thickness has been 11 to 1 or 10 to 1 .

To go into further detail is unnecessary, as a number of other counts give similar results. The diameters of a considerable number of wood fibers well enough preserved to be reliably measured varied from 50 microns to 25 microns. The diameters of a number of carbonized cells measured between 30 and 35 microns. Therefore, from 25 to 50 microns may be relied upon as the approximate thickness of these wood fibers.

The thicker anthraxylon components evidently have not been reduced in thickness as much as the thinner ones, and in general the thinner the component the more have the cells been reduced. In other words, the greater the maceration the greater has been the loss of the cell mass.

These few measurements indicate progress toward definite determination of the amount of compression and reduction of volume in the change from peat to coal, but more extensive measurements are required to make safe conclusions. However a definite conclusion in this much-discussed problem, is now more possible than it has been in the past.

RESINOUS INCLUSIONS.

Many of the anthraxylon components contain inclusions similar to those found in Tertiary and Cretaceous lignites. In these lignites the woody coal usually has been preserved so well that the genera and. 
some specimens, species can be determined, and the structure is osely related to that of living species. Almost all the parts of ems thus identified have proved to be those of conifers whose natomy is well known, and wherever inclusions were found in the gnites they proved to be the natural resins of the plant. ${ }^{a}$ The ssumption is fair that similar inclusions found in bituminous coals, 1 those parts derived from the woody parts of plants and retaining 1e original cell structure, are also natural resins and represent taterial, more or less changed, secreted by the plant when living. uch resinous inclusions in anthraxylon matter are abundant in all 1e Paleozoic bituminous coals that have been examined. Some Jals, as that from the Vandalia mine and the Buxton mine, contain considerable proportion of such anthraxylon matter, others comaratively little. The percentage on the whole is small.

There are clearly two types of resinous matters, and each is inluded in a different kind of woody structure. The one is always arply differentiated from all other resin-bearing matter, both 1 that the anthraxylon including the resinous matter is of a lighter olor, always of the same type of structure, and the resinous matter ; always of a light, clear, yellow color, easily distinguished in the oal. This type is shown in Plate LIX, $B$, from the Oak mine; 'late CI, $A$ and $B$, and Plate CII, $A$, from the Sesser coal, and Plate 'XIV, $A$ and $B$, from the Shelbyville coal. This type constitutes $\mathrm{n}$ appreciable part of all coals examined and has the same appearnce in all of them.

The tissues that include this type of resinous matter appear to be hose of Gymnosperms, but they have not been examined sufficiently $\jmath$ draw a positive conclusion. Wherever this type of anthraxylon is ound it shows definite bands with better preserved cell structure and arger resin contents, alternating with bands in which the cell strucure is not so well preserved and in which the cell contents are ither empty or small, and it clearly resembles annual growth rings n living trees. In a number of specimens examined, a series of ells with the thickened cell walls lie just below or within the tier $f$ cells containing the most resinous matter, as seen in Plate CI, 1 and $B$, Plate CII, $A$, and Plate CXIV, $A$ and $B$.

The resinous matter, according to the amount contained in the cells, tas assumed shapes in cross section from oval or almost circular, vhere the cells originally were filled, through lenticular shapes to ilar in which the cells originally must have been almost empty. The cells have collapsed to the extent permitted by their contents; iome of the cells that have collapsed completely contain no resinous natter, as is well illustrated in the photographs referred to in the

a White, David, and Thiessen, Reinhardt, Origin of coal : Bull, 38, Bureau of Mines; 914, 390 pp. 
preceding paragraph. This type of resinous matter contains no bubbles or vacuoles so common in the other type. The mass is completely homogeneous as far as can be determined by means of highest powered lenses; that is, no granules, common in the woody matter in coal, can be detected. The lines or other abrasions seen in the photographs are mostly due to marring of the sections in cutting them.

The second and commoner type of resinous matter probably is derived from several kinds of plants as their sources. A number of recurring types of structure are recognized, each one including a different type of resinous matter. These resinous contents differ from one another more in size and form than in color or any other physical character. In color, consistency, and transparency they are similar to each other and also to the tissue including them, so that often they are not easily distinguished from the tissues. Many contain racuoles or bubbles of greatly varying sizes, which when present afford a sure sign for their recognition; others contain lines of refraction, very irregular canals, or signs of apparent breakdown or granulations. Aside from these inclusions, the mass of the particles is usually homogenous or very finely granular, differing markedly from the anthraxylon components, which as a rule are coarsely granular. In certain specimens the particles have unmistakably been found to be roid in form. This is clearly shown in Plates CXLVIII to CL, a series from the Vandalia coal.

Characteristic illustrations of anthraxylon components with resinous inclusions are seen in Plate XLVIII, $B$; Plate XIIX, $A$; Plate LXIX, $A$; Plate LXXVIII, $A$; and Plate C, $B$.

\section{THE KINDS OF TISSCES REPRESENTED IN THE COALS.}

An examination of sections from a number of coals, as those in the illustrations presented, shows that by far the larger proportion of the tissues remaining represent woody parts of plants; that is, parts of stems, branches, twigs, and roots, including all the tissues, except the bark, that goes to make up such a part of the tree or shrub. It can not be said with certainty that bark has contributed appreciably to the constituents in question. If bark is present at all in coal it finds its recognition possibly in components that seem wholly different, a point to be discussed later.

The anthraxylon of the dull coal, then, is derived for the most part from rather small chips of semidecayed woody tissues, such as are prevalent in many peat bogs of to-dar. Prosenchyma, or wood proper, and parenchma, such as cortex, pith. and rays, are all found and are clearly distinguishable. Nevertheless there is no doubt that some of the structure seen in thin sections is derived from the more succulent or younger parts of plants, some of which are herbaceous. 
Leaf strands, with some of the accompanying tissues, petioles, and sther vascular strands are frequently detected. What seem to be delicate tissues of plants are frequently seen, as in Plate LXXIII, $A$, which is a section of the Pittsburgh coal. The parenchyma of leaves is rarely observed, yet occasionally structures are seen that might be construed as having been derived from leaf parenchyma, and some structures represent unmistakably leaf tissues. In Plate CXX all the leaf tissues, particularly the palisade cells, are well represented. Compare the leaf tissues of a living Cycad, shown in Plate IX, $A$. Usually the matter contained between leaf cuticles has disintegrated beyond identification.

\section{CUTiCles.}

In all leaves, petioles, green parts, young stems, twigs, fruit, and seeds of plants the outermost layer of tissue consists of tabular cells that are closely united and are uninterrupted except by stomatal pores. This layer is the epidermis. In some plants this layer persists with little change; in others it is thrown off sooner or later and replaced by a layer of cork.

The exposed surface of all epidermal cells are covered with a layer if cutin forming a continuous transparent film or membrane over he entire surface of leaf or stem. This film is called the cuticle. See Pl. IX, $A$ and $B$.) It is present on all leaves, petioles, green ir young stems, twigs, fruits, berries, and sometimes persists on lder stems and branches. In many plants the cuticle is covered with vaxy and resinous matter, and in some this matter is abundant nough to have commercial importance, as in the wax palm (Ceroxyon andicola) and the bayberry (Myrica cerifera). The waxy coatngs may form coherent layers or incrustations upon the cuticle; or nay consist of vertical rods, of short rods or rounded grains, or of ninute grains or needles.

The cuticle resists the action of putrefying organisms and persists under peat-forming conditions after most of the underlying tissues ave disintegrated or have disappeared. Cuticles or fragments of uticles are always present in peat, occasionally in large proportions.

\section{CUTICLES IN COAL.}

Similarly in coals a large amount of cuticular matter and some suticularized tissues have survived and are present, often forming xppreciable proportions of the "dull coal." (Pls. XXIV, $A$, and XCVIII, $A$ and $B$.)

In thin sections, under the microscope, many cuticles appear as jright golden yellow bands of considerable length and relatively aarrow. One edge is usually smooth and the other is usually serrate. Frequently cuticles occur in pairs with the smooth edges toward 
each other. In Plate XCVIII, $A$ and $B$, taken from a section containing a large proportion of cuticular matter much like that shown in Plate XXIV, $A$, the cuticles are represented by light-colored bands, sometimes in pairs, embedded in a débris derived largely from leaves and other vegetable matter. Cuticular matter is also present in coals in a macerated or more or less fragmented condition. In this condition it forms a constituent of the attritus, and is often difficultly distinguishable from fragmentary spore-exine matter.

Like the spore-exines the cuticles may be separated easily from the coal by means of Schulze's reagent. When thus separated they appear as tissues or films constructed of cells (Pls. CXIII, $A$, and CXXXVI, 5). They are, however, noncellular, transparent membranes and the apparent cell structure is due to ridges on the under surface that conformed to the once underlying epidermal tissue. A considerable number of patterns of the apparent cell structure, or in other words, different types of cuticles, are present; indicating that a number of different species or genera of plants are involved.

BARK.

Nothing has been observed that could be said with certainty to have been derived from bark. There is, however, a constituent reoccurring in all coals, most frequently in the Pittsburgh coal, that might be interpreted as derived from bark. It is shown in Plate LXXXIII. This component is always dark brown, lumpy, porous, large-meshed, and of irregular structure. By far the largest proportion of this component has retained some of the original plant or cell structure, but this structure is poorly and irregularly preserved, and seems to be derived from large-celled tissues. It almost always includes a large number of resinous appearing globules, and frequently more highly carbonized matter, and parts of the tissue, or strands of tissues, in which the plant structure is well preserved. In some of the components the whole mass is fairly well preserved, but in others the whole mass has disintegrated into irregular fragments, having the same color and general appearance. Frequently the component is composed of bands of tissues alternating with bands of granular, disintegrated matter.

As seen under the microscope the components vary much in size and also in transparency. The most transparent ones are dark brown in thin, but opaque in medium thick sections.

This constituent, possibly derived from bark, is characterized by its brownish red color in thin section, irregular structure, lumpiness, and relative opacity, and it is easily distinguishable from the rest of the coal. Although in some layers or lamina it may be quite abundant, yet it forms but a small part of all the coal. 
THE ATTRITUS.

An examination of the attritus at a magnification of more than 200 diameters shows that it is composed largely of definite units or welldefined particles and contains very little amorphous material. These units, or particles, constituting the attritus consist chiefly of woody degradation products or humic matter, spore exines of a large variety, resinous particles of various origins, particles derived from plant tissues in a more highly carbonized condition or carbonaceous matter, and mineral matter such as pyrite granules and sand. These constituents are present in greatly varying proportions, but the most important are the first three named. Occasionally the carbonaceous matter also becomes predominant.

\section{THE OAK MINE COAL; CROSS SECTIONS.}

An examination of some of the illustrations will verify this general statement. Plate LI, $A$ (magnified 200 diameters), representing coal from the Oak mine in the Pittsburgh seam, and prepared from the same cross section as Plate XLV, $A$ and $B$, represents a portion in cross section of a typical attritus that contains a large proportion of spore exines, shown here as small, irregular white linear patches embedded in a darker groundmass. The mass in which the spore-exines are embedded is shown in detail in Plate LI, $B$, an area included in Plate LI, $A$ (magnified 1,000 times). It should be considered that the actual area represented in this photograph is of microscopic size, measuring only about one-tenth of a millimeter, or 100 microns, in diameter. In this photograph the cross sections of the spore-exines are shown as heavy white wavy lines. These represent collapsed spheres with the spore walls pressed together closely; in some the remaining cavity is clearly shown. The wavy or crenulated outline is in this spore is due to serpentine ridges on the surface of the spore wall, better shown by the horizontal sections (Pl. LXI, $B$; PI. $\mathrm{LXXV}, A$; Pl. LXXVI, $A$ ), and by the isolated spore-exine shown in Plate LXXXII, 1 and 2.

Lodged between the spore-exines are seen degradation products of cellulosic origin, shown in gray, a few resinous particles, also in gray, and darker carbonaceous matter in black. Under the microscope the spore-exines are light-yellow, translucent bodies; the anthraxylon components and other cellulosic degradation products are orange to light red, being similar in color to the larger anthraxylon components; the resinous particles also are of a similar color; the more carbonaceous components appear red to dark red in thin sections, and are opaque in thicker sections. As seen in these and other photographs, much of the anthraxylon matter consists of very fine particles, homogeneous in appearance at magnification of 200 diameters, but resolved into fine particles at 1,000 diameters. 
Plate LIII, $A$, taken from an area of the section included in the lower part of Plate XLIV, $A$, shows the relative sizes and proportion of the different components. The attritus is composed largely of spore matter, but also contains some humic matter besides the thin anthraxylon strips running through it; carbonaceous particles of a relatively large size are also numerous. The large number of dark patches represent the more carbonaceous anthraxylon components. These are dark red and almost opaque under the microscope. In thicker sections they are opaque, but in thinner sections they become translucent and have a very dark red color, to which a spectrum or a panchromatic plate is not sensitive, and hence they are represented in black in the photograph. Plate LIII, $B$, represents an area included in Plate LIII, $A$, at a magnification of 1,000 diameters. The spore-exines are in white, the more carbonaceous anthraxylon matter in black, and the general anthraxylon or humic matter and the resinous matter are gray. The attritus does not always contain such a large proportion of spore matter as shown in the foregoing illustrations.

Plate $\mathrm{L}, A$, shows a part of a lamina that contains relatively few spore-exines, a large proportion of finely divided anthraxylon particles or humic degradation matter, shown as thin gray objects, resinous matter shown as gray oval or ovoid bodies, and some carbonaceous matter shown as black oval and irregular objects. Plate LIV, $A$ and $B$, and Plate $\mathrm{LV}, B$, show varying proportions of the constituents of the attritus, but the fact that humic particles, sporeexines, resinous, and carbonaceous matter form the chief constituents in all illustrations should be noticed.

THE RNPERIMENTAL MINE COAL; CROSS SECTIONS.

The coal from the experimental mine, at Bruceton, does not differ materially from that of the Oak mine. As the only coal examined from this mine has been from samples gathered by standard sampling methods, the horizon of the seam that the coal represented is not known. A number of sections have been prepared from such samples, but the differences as seen in these sections have not been greater than are shown in the coal from the Oak mine, in the series taken from top to bottom. The proportion of the attritus to the anthraxylon, as far as can be learned from the sections on hand, and as may be seen from the photographs, is about the same as that in the coal from the Oak mine. The constituents of the attritus are also the same kind as those in the attritus of the Oak mine. Also the relative proportion of each constituent is similar.

Plates LXIII to LXVI represent intervals of a continuous strip of the coal from the experimental mine. The cell structure is apparent everywhere in the anthraxylon matter. Little spore mat- 
ter is noticeable in these sections; there is considerable resinous appearing matter, the finer matter interlayered with the fine débris between the anthraxylon strips, and also some highly carbonaceous matter, particularly in Plate LXVI, where it appears as irregular oval granules. Plate LXVII and Plate LXVIII, both from the same section, show considerably more spore matter and macerated matter. The anthraxylon strips 6-a and 8-a in Plate LXVII appear homogeneous in the photograph, but under the microscope, with proper illumination, remains of original structure are clearly seen.

Plate LXIX, $A$, represents a part of a section in which the anthraxylon components with well-preserved cell structure are embedded in a highly carbonaceous attritus. The light-colored lump at $3-\mathrm{d}$ is a mass of closely united spore exines. Plate LXIX, $B$, represents layers rich in spore matter, seen everywhere in this coal. The dark lumps at $2-\mathrm{d}$ and $4-\mathrm{d}$ are resinous appearing, opaque inclusions. Plate LXX, $A$ and $B$, represents areas from similar layers shown in Plate LXIX, $B$, at a magnification of approximately 1,000 diameters, and show the nature of the matter in which the sporeexines are embedded. The exines appear to be the same as those seen in the Oak mine coal. Plate $\mathrm{LXX}, A$ and $B$, shows the various constituents distinctly; the gray humic matter, the dark carbonaceous matter, some of it in very minute particles, the more homogeneous resinous bodies, and the lighter spore matter are all shown as individual particles. Attention is again called to the fact that the original areas represented in Plate $\mathrm{LXX}, A$ and $B$, are only one-tenth of 1 millimeter in diameter.

THE OAK MINE COAL; HORIZONTAL SECTIONS.

As in examination of the anthraxylon components, sections of the attritus cut parallel to the bedding planes are particularly well suited for the examination of its components. The remaining plant cells of the components of the débris, like the cells of the larger anthraxylon coal, are mostly flattened, lying horizontal with the bedding planes. A section through them, or including them in whole or in part, exposes the larger part or surface to view, and if any characters are retained they are far better visible on the broad sides than on the edges exposed in a cross section. Plate LXI, $A$ (magnified 150 times), Plate LXI, $B$, taken from an area included in the former and magnified 1,000 times, Plate LXII, $A$ (magnified 150 times), and Plate LXII, $B$ (magnified 1,000 times), from an area included in Plate LXII, $A$, are from horizontal sections prepared from the same sample as Plate XLIV, $A$, and Plate XLV, $B$. It must be considered that the photographs represent only a small part of the sections selected from representative areas, and that since the 
smaller anthraxylon components are both numerous and as a rule quite closely packed together, a large proportion of any horizontal section is usually occupied by anthraxylon. Plate LXI, $A$, corresponds to a layer of coal similar to that shown in Plate LI, $A$, and presents a large amount of spore matter, represented by the smaller circular to oval white areas, which are spore-exines lying on their broad sides. The irregular gray components among the spore-exines represent the humic matter, and the black irregular parts represent the darker and more opaque or highly carbonized matter. Plate LXI, $B$ (magnified 1,000 times), shows in detail the spores, their shapes, surface markings and distribution, and the more carbonaceous or more opaque components. These are embedded in the fine groundmass composed of humic matter, consisting of still more finely divided matter. Plate LXII, $A$, corresponding to a portion of coal shown in cross section in Plate LIV, $A$, shows relatively little spore matter but considerable humic matter and opaque matter, both mineral and carbonaceous. In the lower right-hand part of the photograph is part of an anthraxylon component with the cell structure well preserved. Other small anthraxylon fragments appear in other parts of the photograph. Plate LXII, $B$, is from an area of the section included in the former photograph, magnified 1,000 times. Besides the spore-exines common in the Pittsburgh seam, such as are shown in Plate LXI, $B$, it shows other species of spores common in almost all coals examined. (See chapter on "Spòre Exines," p. 67.)

\section{EXPERIMENTAL MINE COAL; HORIZONTAL SECTIONS.}

Horizontal sections of any coal are always of special interest, as they bring out much general detail that is usually overlooked, particularly the individuality of the various components. Although this is true of all the coals shown, it is especially true of those from the experimental mine. Study of these photographs, and those of cross sections, will remove any wrong ideas as to the homogeneity or amorphous condition of the mass.

Plate LXXV, $A$, represents a section through a typical attritus consisting of very finely divided humic matter, spore-exines, a little resinous matter and the more highly carbonized matter, and some earthy matter, each clearly distinguished from the other. Plate LXXIII, $A$ and $B$, and Plate LXXIV, $A$, both magnified 150 times, show the same wherever the sections cut through the attritus. These should be compared with Plate LXXV, $A$ and $B$, and Plate LXXVI, $A$ and $B$, at a magnification of approximately 1,000 diameters. In some of these certain objects such as sporeexines appear to be embedded in a homogeneous mass, as 
in Plate $\mathrm{LXXV}, B$. On close inspection it will be seen that the section includes an anthraxylon fragment, in which the woody structure is clearly recognizable, and that the individual particles composing the attritus lie closely against the former but are not actually embedded in it. If such a section is compared with a cross section, especially at a magnification of 1,000 diameters, it will be seen how closely packed and how intimately united the particles are, nevertheless representing definite and individual objects with definite boundary lines. Plate LXXV, $A$ and $B$, gives a clearer idea of the sculpturing of the predominating spore-exine in this coal than any of the other photographs. Plate LXXVII, $A$ and $B$, represents cross sections of the coal of the Pittsburgh seam from Madison, Pa., and Plates LXXVIII to LXXX from unknown localities of the Pittsburgh seam. These coals do not differ materially from those already discussed.

\section{SECTIONS OF OTHER COALS.}

ILLINOIS COALS, FROM THE NO. 6 BED.

In general the coals from the No. 6 bed of Illinois, namely, from the Hart-Williams mine, from the mine of the Benton Coal Co., both near Benton, from Zeigler, Royalton and Sesser, all in Franklin County, are similar to the Pittsburgh coal. As detailed an interpretation as was given for the Pittsburgh coals will not be necessary as the reader has become familiar with the appearance of the coals in the photographs, and is able to interpret them himself. Plates LXXXIX to CX represent coals from vein No. 6 of the Illinois coals. When Plates LXXXIX to XCI, Plate CVI, and Plate CVIII of the Illinois coals are compared with Plates LI, $A$; LIII, $A$; LIV, $A$; LXIX, $B$; LXXVII, $A$; and LXXX, $A$, of the Pittsburgh coal, the resemblance of the attritus is striking. Many photographs could be taken that would practically duplicate each other. Plate LXXXIX, $A$, and CVIII, $A$, show typical attritus of these coals. Interlayered between the anthraxylon strips, the spore-exines may be recognized embedded in a matrix consisting of humic matter, resinous particles, and the opaque or more highly carbonaceous matter. In the sections under the microscope various mineral constituents may be observed, as in the Pittsburgh coals.

Plate LXXXIX, $B$; Plate XC, $A$ and $B$; Plate XCV, $A$ and $B$; Plate XCVI, $A$ and $B$; and Plate CVIII, $B$, at a magnification of 1,000 diameters, show that the attritus is here also composed largely of definite particles intimately united into a compact mass.

The ratio of the various constituents forming the mass varies considerably, but on the whole the proportion of carbonaceous matter is small and the proportion of humic matter is large. The propor- 
tion of spore-exines is variable not only in the different coals from the vein, but also in different sections of the coal from the same locality, and even in the different striæ in the same section. Spores form an appreciable part in these coals, as large a part as in the Pittsburgh coal.

THE COAT FROM THE BUXTON MINE.

The attritus of the Buxton coal is composed of the same kinds of constitutents as that of the other coals, but the constituents are comparatively coarse. The spore-exines are large, the humic matter consists chiefly of coarse irregular, flat particles, and the resinous matter consists of large, regularly shaped particles. These constituents are mixed with a large proportion of opaque matter, which in certain layers appears as definite irregular particles; in some it is arranged more or less in sheets and in others it forms the embedding mass for the other constituents. This is well illustrated in Plates CXXV to CXXVII. Much of the opaque component is earthy, and differs from the carbonaceous matter, of which there is also a considerable amount present, in that it is absolutely opaque and has an earthy appearance. Although the relative proportion of the organic constituents of the attritus varies from place to place, in most of the samples there is about 50 per cent of each. Granules of iron pyrites form a considerable amount of the attritus of this coal.

THE SIPSEY COAL.

The attritus of the Sipsey coal, shown in Plates CXXXVIICXXXIX, varies considerably in its appearance and in the relative amounts of its constituents, although the latter are of the same kind as in other coals. It is similar to that of the Pittsburgh coals; in some respects and similar to that of the Buxton coals in others, and may be said to consist of two kinds. It contains less opaque earthy matter and is, therefore, of a lighter color than the attritus of the Buxton coal. The resin content is also lower and the humic matter is more finely divided.

\section{THE VANDALIA COAL.}

As has already been pointed out, the Vandalia coal is very anthraxlous and contains only a small amount of attritus. This is similar in content to the attritus of the Illinois coals, though it contains much finely divided humic matter and relatively little spore matter. Iron pyrites grains are fairly numerous in the attritus, and are sufficiently abundant in some layers to give them an opaque appearance. (Pls. CXLIII to CL.) 
THE CARBON HILL COAL.

The attritus of the coal from Carbon Hill is in every respect very similar to that of the Pittsburgh coal. (Pls. LXXXIVLXXXVIII.)

\section{THE COMPONENTS IN DETAIL.}

In the foregoing chapter the author has sought to show that in all ordinary bituminous coals the attritus is similarly composed and that it is analogous to the attritus in peat. Although the proportions of various constituents may vary considerably, or their appearance and kind may differ slightly, in general they are all of the same class. The main constituents forming the attritus will be considered under five heads, as follows: The humic matter, resinous matter, the spore-exines, fungi, other organisms, the carbonaceous matter, and the rodlet.

\section{THE HUMIC MATTER.}

Humic matter comprises all matter in a finely macerated condition derived from plant tissues, but usually not revealing original cell structure, and does not include spore-exines, pollen-exines, cuticles, and resinous matter. The latter class of components is of microscopic fineness, including particles easily visible under the microscope, and such as are too fine to be recognizable except by ultramicroscopic means. The latter class is usually termed "homogeneous matter," and there is remarkably little of it present in most coals. The origin of the humic matter is considerably wider than that of the anthraxylon, as was seen in the study of the origin of the attritus in peat. Chemical tests and the history of humic matter in peat show it to be chiefly of cellulosic and lignocellulosic origin. It consists largely of macerated wood fibers and parenchymatous cells, with some macerated walls of bark, cork, phloem, pith, leaf tissues, and also some gummy substances from any and every plant that contributed to the deposit. It has therefore much the same nature as the anthraxylon.

The color as seen in thin sections is similar to that of the anthraxylon, ranging from a light orange to a deep red. Its physical appearance is also similar to that of the anthraxylon of the same coals, and by its color and physical nature it may readily be distinguished from the other constituents of the attritus.

The humic matter has already been indicated in the photographs accompanying the general discussion of the attritus. Although humic matter is apparent in every photograph showing attritus, reference is made to the following photographs in order to recall its general appearance and nature. Plate LIV, $A$; Plate LV, $B$; Plate LVIII, $A$; Plate LXI, $A$ and $B$; LXII, $A$ and $B$, of coal from the Oak mine; 
Plate XLIII; Plate LXX, $A$ and $B$; Plate LXXII, $A$; Plate LXXIV, $A$ and $B$; Plate LXXV, $A$ and $B$; Plate LXXVI, $A$ and $B$, of coal from the experimental mine; and Plate LXXIX, $A$ and $B$, and Plate LXXX, $A$ and $B$, from other parts of the Pittsburgh seam, give a good idea of the humic matter contained in the Pittsburgh coal.

Other good illustrations are Plates LXXXVI and LXXXVIII, $A$, of the Carbon Hill coal. Plate LXXXIX, $A$, and particularly Plates LXXXIX, $B$; XC, $A$ and $B$, at 1,000 diameters, of the Hart-Williams coal; Plate CVI, $B$, and Plate CVIII, $A$, of the Royalton coal, give good illustrations of the humic matter in the Illinois coals in a granular condition, and Plates XCV and XCVI show it in a homogeneous condition. Attention is called to Plate CIII, $A$ and $B$, and Plate CIV, $A$, of the Sesser coal, which show much humic matter in the shape of large irregular, angular bodies, differing in appearance from either typical humic or resinous matters. The most pronounced granular or comminuted condition is found in the Shelbyville coal, shown in Plate CXV, $A$, and Plate CXVI, $A$. Plate CXV, $B$, and Plate CXVI, $B$, at 1,000 diameters, from the same coal, do not show the granular condition so well, but do show the nature of the very fine humic matter in which the larger humic particles and the sporeexines are embedded. The Buxton coal has a mass of coarse material of various forms and appearance (Pl. CXXIV, $B$ ), consisting largely of irregular flat particles, in places associated with rounded particles (Pl. CXXV, B) that may be resinous or merely humic. Bodies of a similar nature appear in Plate CXXVI, $B$. As they are lighter colored than the anthraxylon and other typical humic matter, they may be resinous. The appearance of the humic matter in horizontal sections of this coal is shown in the Plates CXXVIII, $A$ and $B$, and CXXIX, $A$ and $B$.

An examination of the photographs at 1,000 diameters will show that there is very little humic matter in a homogeneous condition, to which fact due attention has been called in connection with the general discussion of the attritus.

\section{THE RESINOUS MATTER.}

Universally scattered through the attritus of all bituminous coals are certain particles that form an appreciable part of many coals. These are rarely angular, have a homogeneous consistency, are brownish red and similar to the anthraxylon components and the humic matter in color, and are optically active.

They are termed resinous bodies or particles, as they are analogous to the resinous components of the lignites, the origin and identity of which are more certain. Microchemical tests give positive testimony of the resinous nature of these bodies in the lower grades of 
lignites, but every attempt to obtain proof of their resinous nature in bituminous coals has failed. For that matter, in coal derived from the woody or cellulosic parts of plants chemical tests also fail to show their chemical nature or origin, but here the remaining original plant-cell structure in which they are found furnishes positive proof of origin. The free resinous matter shows also the form and other characteristics like that of the resinous matter in recent plants, but this evidence is not as reliable or as certain as the presence of the remaining cell structure of the anthraxylon components.

\section{OCCURRENCE.}

The so-called resinous components still remain, as a whole, the least known and the most indefinite constituents of bituminous coal and the most uncertain as to origin.

Fortunately there are a number of transition stages from that in which the resinous particles are included in a fairly well preserved woody tissue to that where they are free in the attritus. Plate $\mathrm{CL}, A$, shows an anthraxylon component in parts of which the tissue including numerous resinous particles in its characteristic way is very well preserved, and leaves no doubt that it is a remnant of a resinous plant; in other places of the same piece the woody tissue is in various stages of decay, the cells appear disintegrated and indefinite, and the resinous particles, apparently well preserved, lie free in the débris or are partly included in fragments of the tissue. This is partially shown in Plate CXLIX, $A$. In other places the cell structure has disappeared almost completely, leaving little else but the resinous matter. (Pl. CXLIX, B.) Furthermore, the Vandalia coal contains a number of other anthraxylon strips in which similar resinous bodies are still included in situ. (Pl. CL, A.) Numerous resinous bodies similar to these are scattered free throughout the coal. The Vandalia coal may be termed an anthraxylon coal, and many of the anthraxylon components are resinous. Some of the resins included are of the kind mentioned, others differ, but many of the types seen in place are also recognized among those scattered free through the coal. Similar transition stages have been observed in other coals.

Here, then, are certain constituents that are included in the tissues of certain plants. In the living plants such inclusions are almost always the natural resins, though a few may be gums and waxes. There is every reason to believe that similar inclusions in the tissues of the Paleozoic plants are resins, and that a few may be gums or waxes. Bodies or particles that resemble in every respect the inclusions in the anthraxylon components are found free in this 
coal; and the conclusion that these also are of a similar origin and are resins or resinous particles is reasonable.

Every coal examined has particles of similar nature and appearance scattered through it. Some coals, like the Vandalia coal, contain a great many, probably one-fourth to one-third of certain laminæ of this coal being of a resinous nature; other coals contain much less. The Buxton coal contains the next largest percentage of resinous matter. (Pls. CXXIV-CXXVII.)

\section{SOURCES.}

Three sources of resinous secretions are recognized in living plants: The stem, the bark or cortex, and the leaves. Only evidences of resinous contents of the stems have previously been cited. In the Buxton coal appearances clearly tend to show that some of the resin particles scattered through the débris undoubtedly had their origin in the stems of plants, as similar types are found still in place in great numbers; but others apparently had their origin in leaves. The latter lie in straight rows, in single, double, and occasionally in triple rows. Frequently they are included between rather heavy cuticles, as shown in Plate XCVIII, $A$ and $B$, of an Illinois coal. When thus associated with cuticles, it seems that they are the residue of the leaf of which the cuticles once were a part. When they are not included between cuticles the evidence is not so clear. Plate CXXVI, $B$, shows a single row of resinous-appearing bodies not included between cuticles. Resinous particles included between cuticles are found also in other coals.

Besides these two classes that may be associated with each other, there are in these coals a large variety of particles scattered throughout the débris that can not be definitely placed, but nevertheless, have all the characteristics of resins. Plate CIII, $B$, and Plate CIV, $A$, of the Sesser coal, show particles that are of a resinous consistence. but do not have the usual form of resinous particles.

\section{DISTINGUISIIING CHARACTERISTICS.}

Although the resin particles resemble the anthraxylon or humic components closely in color, transparency and consistence, they may usually be distinguished through their form and particularly through their homogeneous consistence. When examined in cross sections the resin bodies appear rounded or oval, rarely angular, whereas the humic components even when in minute fragments are thin and flat and usually angular. The resinous substance is homogeneous, or finely granular, whereas the substance of the humic matter is always coarsely granular and readily distinguishable from the former. 
In the horizontal sections the distinction between the resinous and humic contents through their form is not always so easy, especially when the former had their origin in wood fibers and the latter are in a fragmentary condition. But when the resinous particles are ovoid or approximately spherical, as shown in. Plate CXLIX, $B$, they are easily distinguished. Often when the resinous particles are from the contents of a cell fiber, as in the wood of our recent conifers, the particles contain peculiar constrictions, or indentations, or a number of vacuoles that identify them. Most resin particles, whether ovoid, spherical, or fibrous, contain numerous vacuoles or fine bubbles that appear to be characteristic of resinous bodies. Nevertheless, there remains a relatively small amount of the fragmentary matter that must be classed either with the resinous or the humic matter, but can not as yet be safely identified.

Characteristic resinous particles are shown in Plates CXLVII, $B$, CXLVIII, $B$, CXLIX, $B$, of the Vandalia coal; Plates XLIX, $A$ and $B, \mathrm{~L}, A, \mathrm{LXX}, B, \mathrm{LXXVIII}, A$, of the Pittsburgh coal; Plates XCIII, $A, \mathrm{XCIV}, B, \mathrm{C}, B$, of the Illinois coal; and Plates CXXV, $A$, and CXXVI, $B$, of the Buxton coal.

\section{THE SPORE-EXINES.}

Next in importance in the attritus are the spore-exines. None of the coals examined are free from them. Even the coal with the least number of spore-exines, the Vandalia coal, contains on the whole a considerable proportion of exine matter. Examination of the photographs will probably not give an absolutely correct idea of the proportion of spores to other components of coal, but they may be depended upon to furnish a general idea of the proportion of spores in the attritus. The photographs taken at a magnification of 200 diameters have for the most part been selected to show average conditions.

No attempt at taxonomic identification was made, as that would involve an extensive study and would probably be out of place here, no matter of how great interest it may be in other fields. Only such characteristics will be pointed out, as size, form, structure, distribution, types and predominance of certain types in certain coals.

\section{SOURCES.}

As to the origin of those bodies, called spore-exines, there can now be no doubt. The only question that can arise is whether they are the exines of true spores of mosses, Lycopodiales, and Filicales, or the pollens of gymnosperms.

Thus there is the possibility of having in the Paleozoic coals spores from three great groups of plants: Mosses, Pteridophytes, $125536^{\circ}-20-$ Bull. 117 $\longrightarrow 6$ 
and Gymnosperms. The Pteridophytes may be conveniently divided into three great families; the Calamites, in which may be classed the horse tails; the Lycopodiales, to which belong the club mosses or ground pines; and the Filicales, to which belong the ordinary ferns; the gymnosperms comprised two families. the Cycadofilicales, and the Coniferales. The spores of the last two groups are true pollens. As has been stated repeatedly, all that has survived through the coal forming processes is the outer spore wall or exine, and the chemical nature of the exines, ${ }^{a}$ whether of spores or pollens, is similarly composed. In the living plants this has been shown in the spores of Lycopodium clavatum by Langer, and the pollen of the hazel by Von Planta, and of Pinus sylvestris by Von Planta and by Krestling. ${ }^{a}$

There is every reason to believe that the chemical composition of the Paleozoic plants was not materially different from that of any of the recent plants. Their life functions and their chemical and physical processes of life and growth must have been the same as that of the plants of to-day. The spore-exines in coal owe their preservation to their resistant chemical nature, a characteristic also of the spores of recent plants.

Under the microscope the spore-exines, on account of their transparency and clear color, are the most conspicuous objects in the coal. They contrast sharply with the woody components and the resinous particles, or with any of the constituents of coal except the cuticles, which are similar in color and transpareney, and are, therefore, readily distinguishable. In thin sections by transmitted light they are clear light yellow; in thicker sections they are golden yellow to light orange. Their consistence is finely granular, particularly noticeable at high magnification. These features are the same for the exines from all the coals examined. At magnifications of about 1,000 diameters spores usually show specific differences through various characters that are well preserved. They have usually retained the common flattened shape so apparent in the photographs from the cross sections. This is nearly always due to the collapse of the shell or exine of the spore through pressure. Change of form otherwise than by flattening is not characteristic of any coal in particular. For example, in the coal from the Vandalia mine the exines in some striæ have assumed a lenticular form, whereas in the same section in another lamina they are present in the natural shape. Sometimes they look as though melted into a little lump. But this condition is sometimes found in certain striæ and sometimes among well preserved exines.

In horizontal sections the spore exines appear as circular or oval areas, many of which tend to be triangular. When isolated from the

${ }^{a}$ White, David, and Thiessen, Reinhardt, Origin of coal : Bull. 38, Bureau of Mines, 1914, pp. 274, 275 . 
:oal they are thin disks, unless they have been changed in some way or another into irregular shapes.

IIETRASPORIC MARKINGS AND SCULPTURING.

All the true spore-exines show the tetrasporic markings, which Ire usually on the broad side; the exine predominant in Pittsburgh :oal has these markings most often along the periphery of the disk. The outer surface of an exine may be smooth, sculptured or beset with spines, papillae, or other appendages; in many exines these are urranged in definite order and occur in a variety of forms. These ;culpturings may be serpentine ridges, as in the predominant exine if the Pittsburgh coal (Pls. LXI, $B$; LXXV, $A$; and LXXXII, - and 2), or merely irregular elevations, as in the exine from the Sesser coal (Pl. CXII, -7); they may be echinate spines, as represented in Plate CXXXVI, 3, long heavy spines, as shown in Plate IXI, $A$ and $B$, or delicate spines, as in Plate CXII, 2 and 3 ; they nay consist of ramenta covering either the whole surface, as shown n Plate, CXXXII, 1 to 4, or confined to a small area, as in the sxines shown in Plate CXXXV, 1 to 6. The outer part of some 3xines has developed into a thin fringe or border surrounding the whole spore (Pls. CXVII, 1), appearing as a zone in the collapsed 3xine, and in some exines the outer part has developed into sacks, of which there are three in the Buxton megaspore-exine shown in Plate CXXX, $A$ and $B$, and Plate CXXXI, 1 to 4 ; and others have a number of wings, as shown in Plate LXXII.

In the exines of the pollen the disks are invariably oval or ovoid. They have no tetrasporic marks, but almost all have a slit parallel to the long axis of the oval. Many of these slits have a short cross slit at or toward one of the ends. So far as can be observed the surfaces of the pollen exines are smooth. They are all similar in shape but differ greatly in size. (Pls. LXII, $B$; LXXVI, $A$ and $B$; LXXXII, 4; CXII, 4 and 6 ; CXVII, 3 ; CXXIX, $A$ and $B$; and CXXXVI, 2.) This type of exine has been found in every coal examined, and in some coals it is the predominant type of spore matter.

\section{MICROSPORES AND MEGASPORES.}

As with the spores of the living plants there are in the coals two kinds of spores-megaspores and microspores. Microspores develop in large numbers in a sporangium and are relatively small. Only one, or a few megaspores develop in a sporangium and they are relatively large. The size of the spore does not distinguish a microspore from a megaspore as much as does its mode of development and especially its function as a spore in the living plant. 
DISTRIBUTION.

The proportion of the spore-exines present in the coals examined varies greatly. The Vandalia coal, as observed from standard samples and one large lump on hand, contains the least of all coals examined, but the coal from Sesser; Ill., does not contain any more. The coal from Shelbyville, Ill., contains by far the most, approximately one-fourth to one-third of the coal being composed of exines. Attention is called to the fact that the cannel coals as far as examined, are composed largely of spore-exines, but cannel coals are not considered in this paper. All the coals examined from the Pittsburgh bed contain a large proportion. Equal to these in sporeexine contents are the coals from the Sipsey mine, Rock Creek bed, in Alabama, and the coal from Buxton, Iowa. The coals examined from Benton, Ill., and Zeigler, Ill., probably contain the average proportion.

The distribution of the spore-exines can best be ascertained by examining the plates. The spore-exines may be very numerous in some layers of attritus and almost absent in another layer in the same section. In some layers they may represent the largest part of the layer, and in others only a small part. In many spots they are bunched and constitute almost the whole lamina or sheet. (Pl. CXIX, B.) These densely crowded laminæ may lie between pieces of anthraxylon or in the attritus.

\section{SPORANGIA AND CONES.}

All the coals examined included nests or lenticular mats that can be isolated quite readily through the maceration process; these prove to be more or less circular lense-shaped bodies about the size of small megaspores and are composed of innumerable microspore-exines very closely united. These are particularly abundant in the coals from Shelbyville, Ill., and Buxton, Iowa, but are found in all coals. (Pl. CXXI, $A$ and $B$, and Pl. CXXII, A.) Many are still surrounded by a wall in which the tissue is still well preserved. (Pl. CXXXIII, $A$ and $B$, and Pl. CXXXIV, A.) Occasionally large nests of such lenticular aggregates of spore-exines, some inclosed by a sporangial wall, are found in close proximity. (Pl. CXXXII, $A$ and $B$.) Occasionally a large number are found packed together, some being inclosed in a well-preserved wall, all arranged around a common axis, and many showing definite remnants of trabeculæ. (Pl. XIV.) These are the remains of sporangia, clusters of sporangia and cones.

The light region at co in the photograph of the lumps of coal from the Benton coal shown in Plates XII and XIII represents part of such a cone. Plate XIV shows part of the same cone magnified ten times. At a higher magnification the remaining cell structure of 
he axis and sporophylls are clearly recognizable, as also the trabe:ulæ of the sporangia.

One of the sporangia in the Buxton coal shown in Plate CXXI, 1 and $B$, at a magnification of 10 diameters, is shown in part in ?ate CXXXIII, $A$ and $B$, at a magnification of 200 diameters.

In Plate CXXXIII, $A$, the tip of the sporangium is shown, also he sporangial wall, which is covered with a cuticle and in which the ell structure is clearly recognized. In Plate CXXXIII, $B$, a more entral part of the sporangium is shown. At 1-sp are seen the immaure spores, at $2-w$ the inclosing wall, and at $3-\mathrm{d}$ the attritus comosed of anthraxylon matter, resinous matter, spore-exines and more arbonaceous and earthy matter. Plate CXXXIV, 1 , represents sart of the former at a magnification of approximately 900 diameters, ihowing particularly the cell structure of the spore wall and the aticle overlying it. Plate $\mathrm{CXXXIV}, B$, shows the spores of the ame sporangium, also at a magnification of approximately $900 \mathrm{di}-$ Imeters; Plate CXXVII, $B$, shows the attritus including spore:xines, shown in Plate CXXXIII, $B$, at a magnification of 1,000 liameters.

An examination of these shows that the spore-exines of the lébris and those still contained in the sporangium wall are of the ame kind-conclusive evidence that the predominant spores of the :oal are from plants that grew in the bog during the peat-forming stage, as it would be impossible for whole cones and sporangia with mmature spores to have been carried far by winds.

All the coals examined contain, besides the free spore-exines disrributed through them, these nests or aggregates of spores representng sporangia or part of cones or whole cones. These are evidently he bodies called middletonite ${ }^{a}$ by Johnston. ${ }^{b}$

\section{TYPES.}

No thorough classification of the spore-exines found in the coals aas been made. This problem is chiefly of palaeobotanical interest ind out of place here, except for its stratigraphic value. This would sermit the classification of certain types of spore-exines in their proper phyla, order, family, genera, or species. For the present reference is made to each exine that is predominant in or characceristic of a certain coal deposit. To try to give a definite name to them without knowing their affinities and relationships, as has been tone by some in the past, would be a waste of time and space. No benefit is gained by naming the exine predominant in and charac-

\footnotetext{
a White, David, and Thiessen, Rheinhardt, Origin of coal : Bull 38, Bureau of Mines, 914, p. 193.

b Johnston, James F. W., On the composition of certain mineral substances of organic rigin. The London and Edinburgh I'hil. Mag. and Jour. of Sci., vol. 12, 1838, pp. 62-163.
} 
teristic of the Pittsburgh seam "Sporangites" Pittsburghensis does Dawson, or "Trilet" Pittsburghensis, as does Bennie and Kid ton, or giving some such meaningless name. When their relatiou ships are known proper names will be given them.

GROUPLNG OF COALS BY THEIR SPORE-EXINES.

Coals from certain beds contain a type of spore-exines that predominant in or characteristic of that bed, or both. Even a casu; examination of the photographs of the coals from the different local ties from the Pittsburgh bed, for example, will reveal a strikin similarity in the predominating mass of the spore-exines. A clost examination shows that the exines are of the same type in every pa: of the seam. In comparing the coal from the Sipsey mine, in tr Black Creek bed, with that from Carbon Hill, in the Jagger bed c Alabama, the type of the exine in each is strikingly different, but th predominating mass of exines in each coal are all of the same kin The same is true for the Buxton coal and for the microspores of tr Shelbyville coal. In each of these coals the predominating spor is characteristic of that coal, for it is found only in that coal. Othe spcre-exines are characteristic of a certain bed, but are not the pr dominant spore, as the beaked megaspore in the Buxton coal or hearily spined exine in the coal from the Hart-Williams, Buxton, an Zeigler mines.

Although not enough coals from the Illinois and Indiana coa have been examined, the observations so far indicate that thes coals may be grouped with respect to the predominating or th characteristic type of spores they contain. This subject may find wide application in determining the different beds in the Illino coal fields, and it deserves careful development.

SPORE-EXINES FROM THE PITTSBURGH SEAM.

In the photographs of the coals of the Pittsburgh bed from th experimental mine, the Oak mine, Madison, Connellsville, a mine $\mathrm{i}$ Ohio, near Moundsville, W. Va., and lumps picked up from time 1 time from coal delivered in Pittsburgh for household use, one tyr of spore-exines predominates in the coal from each locality; clost examination shows a second type, of a larger size, but in relative] small numbers. These two types so far have only been found in th Pittsburgh bed and hence are characteristic of it. Besides these tw kinds a number of others occur in relatively smaller numbers, bi they are also found in other coals.

The characteristic spore-exine of the Pittsburgh seam is a fla tened ovate disk with an average diameter of 15 by 16 microns. is therefore, the exine of a very small spore. The surface is molde 
into closely folded, blunt, serpentine rilges. (Pl. LXI, $B$; Pl. LXXV, $A$, and Pl. LXXXII, 1 and 2.) These ridges seem to be arranged symmetrically with respect to the tetrasporic markings. In some of the exines, as seen in horizontal sections, a groove, which is a part of the tetrasporic marking, runs across the disk, to which the serpentine ridges on either side are symmetrical. (Pl. LXI, $\boldsymbol{A}$ and $B$.) This groove is rarely exposed in horizontal sections. The spore may be readily isolated from the coal by means of the maceration process and studied from all sides. The groove is then seen to lie along the periphery of the disk and to be part of the tetrasporic marking of the spore. In all probability, the groove formed the weakest line or the most flexible zone in the thick exine, and when the exine was put under a stress and the walls collapsed, the bending occurred along this line and hence lay along the periphery in most of the spores. The spore rarely bent at another line than the tetrasporic groove, in which event the groove lay across the disk. In some of the exines the ridges are arranged symmetrically around a certain point or pole of the disk, Plate LXXXII, 2. The disks of such exines are more nearly circular, but some tend slightly to be triangular. The serpentine ridges on the surface gire the exine an irregular wavy outline when seen in cross sections at rery high magnification.

The large spore-exine characteristic of the Pittsburgh bed is shown in Plate LXXVII, Plate LXXX, $B$, and Plate LXXXI, $A$, at a magnification of 1,000 diameters. Cross sections only have been obtained of this type. It is similar in nature and appearance to the smaller spore just described, but is much larger, measuring between 70 and 90 microns across the disk.

SPORE-EXINES FROM TIIE SIPSEY MINE.

The coal from the Sipsey mine has also one predominant and characteristic type of spore-exine. Whether this type prevails throughout the coal bed worked by the Sipsey mine remains to be seen, as only one can of samples taken according to standard methods has been examined from that bed.

The collapsed exine as it occurs in the coal is roughly salver shaped. The disk is not quite circular, but slightly triangular. Its cross section (Pl. CXXXVIII, $A$ and $B$, and Pl. CXXXIX, $A$ and $B$ ) is roughly that of a plano-concave lens, because of the difference in the thickness of the spore wall. In that area of the spore walls where the four spores were united during the tetraspore formation the exine is relatively very thin, whereas the other part of the spore wall is relatively thick. When the spore contents disappeared through decay and the remaining spore wall finally collapsed, this thinner area was almost always pressed down against the relatively thick part opposite, but a part of the thicker area lying on the pe- 
riphery of the thin area was drawn over with it, thus forming a thick outer rim. The isolated spore-exine is shown in Plate CXLI, $B$.

The diameter of the disk of the collapsed spore is between 40 and 50 microns $(1 / 20 \mathrm{~mm}$.), so that the spore was large as compared with the predominant spore of the Pittsburgh bed. The surface is studded with numerous small spines that have a tendency to arrangement in spiral rows.

Many of the exines in the samples examined are well preserved, others are so changed that they present only an irregular mass or little lumps of exine matter, and between these two extremes are all stages. The state of preservation varies in different sections and in different striæ of a section.

SPORE-EXINES FROM THE BUXTON COAL.

A number of interesting types of spore-exines appear in the coal from the Buxton mine. One type is the predominant, and, so far as now ascertained, the characteristic type; another, a small megaspore, seems to be characteristic of this coal, but is by no means predominant.

The spore-exine predominant in the Buxton coal is similar in shape to that of the Sipsey coal. It roughly resembles a plano-concave lens, but the disk is usually oval instead of slightly triangular. (Pl. CXXXVI, 1.) The tetrasporic area of the exine-that is, that area in which the four spores were united during the growth periodappear to be thinner and the free area thicker than the corresponding parts of the Sipsey exine. The thicker part of the spore wall, furthermore, contains numerous vacuoles of varying sizes. For this reason, the texture of the cross section strongly resembles the cross section of an almond shell. Plate CXXVII, $B$, shows the exine in cross section, and Plate CXXXVI, 1, on the broad side. These vacuoles give the exines a reticulated appearance when seen on one of the flattened sides. Spore-exines of similar appearance are found in the cannel coal from Caldwell, Mo. ${ }^{a}$

In the Buxton coal also the remains of parts of or of whole sporangia occur to a large extent, either separate or grouped together into cones or parts of cones. Frequently the sporangium walls still include the spores and in so good a state of preservation that the cell structure is still clearly shown. (Pl. CXXXIII, $A$ and $B$, and Pl. CXXXIV, $A$.) Sometimes the spores included appear to be immature. The spores of almost all the sporangia are of the same type as those that form the predominant type of the coal.

MEGASPORES.

The most interesting spore-exines of the Buxton coal are its megaspore-exines, of which there are several types. The more prominent

$a$ White, David, and Thiessen, Reinhardt, The origin of coal : Bull. 38, Bureau of Mines, 1914, p. 250. 
type, shown in Plate CXXX, $A$ and $B$, may easily be isolated by means of Schulze's maceration reagent, and then handled with forceps for examination. It is relatively large, though not the largest found in the coal, measuring approximately one millimeter across the disk, exclusive of the wings. In a collapsed condition its shape is somewhat triangular, as seen in the photographs just mentioned. This exine is remarkable because of its wings; normally there are three, formed by an extension of the exine wall into loing thin-walled sacks. These sacks are extremely delicate and break off in an attempt to remove the exine from the mass. In Plate CXXX, $A$ and $B$, they appear as short tongues, and represent but a part of the original appendages. A cross section of the exine while still lodged in the coal gives a better idea of the sack and its delicate nature, as shown in Plate CXXXI, 2, in which one of the three sacks, somewhat folded, is seen in cross section. The inner cavity of the exine communicates with the interior of the wing. Plate CXXXI, 1, 3, and 4, are also cross sections of the same kind of spore but the wings are not so well shown. Megaspores similar in size, shape, and general appearance are found in the Shelbyville coal, but the wings here are but very short or stunted compared with those of the Buxton exine. (Pl. CXVIII, $B$, and Pl. CXIX, $A$ and $B$.)

Another interesting megaspore-exine (Pl. CXXXV, 1 to 6 ), has on a small area a profusion of long ramenta, now much curled and disheveled. In the living plant presumably the ramenta start from this area much as the pappus of a thistle or a dandelion seed. The exine is of about the same size as the one described previously but much thinner. It has been found also in the Ziegler and the Royalton coals, though not so frequently.

In another type (Pl. CXXXII, 1 and 4), the whole surface is covered with a ramenta. Plate CXXXII, 1, represents one of these in cross section at a magnification of 40 diameters. Plate CXXXII, 2, at 200 diameters, shows the left end, and Plate CXXXII, 3, also magnified 200 times, shows the right end of the same spore in better detail. Plate CXXXII, 4, shows the end of another exine of the same type. So far this type has been found only in the Buxton coal. Besides these, other megaspores of the ordinary type similar to those of other coals are found, including the giant megaspore prevalent in the Shelbyville coal. (Pl. CXVIII, A.)

PREDOMINANT EXINES OF THE SHELBYVILLE COAL.

Another coal in which by far the greater proportion of the exines are of one type is that from Shelbyville. The exine was described ${ }^{a}$ as constituting the bulk of the spore matter of that coal. This type

$a$ White, David, and Thiessen, Reinhardt, 'The origin of coal: Bull. 38, Bureau of Mines, 1914, p. 263. 
of exine averages approximately 100 microns in diameter, measured across the disk. It has a darker central area which constitutes the spore-exine proper, measuring approximately 40 to 50 microns across the disk, and is comparatively thick-walled. This part is surrounded by a much thinner border approximately 25 to 30 microns wide, the unequal width gives a triangular outline. (Pl. CXIII, B.) Evidently this border served as a wing in the liring spore. The tetrasporic marks extend across the inner or main portion of the exine.

A smaller microspore, found in large numbers, is conspicuous and dominant. It is only a little larger than the central or main part of the spore-exine just described. Its tetrasporic marks are prominent. (Pl. CXVII, 2.)

A giant megaspore of the Shelbyville coal measuring approximately 3 millimeters in diameter is the predominant type of megaspore. It can easily be seen in the coal with the naked eye, appearing as little brown disks. Plate CXVIII, $A$, represents an isolated spore, magnified 35 times. This spore-exine has been found in smaller numbers also in the Buxton and the Pittsburgh coals. A smaller megaspore found in considerable numbers in the Shelbyville coal is shown isolated in Plate CXVIII, $B$, and Plate CXIX, $A$, and in cross section still lodged in the coal in Plate CXIX, $B$. The spore-exines resemble very closely the smaller megaspore-exine found in the Buxton coal in size, general form, and thickness of spore wall, except that the wings or the sacks of the Shelbyville exines are comparatively short and rudimentary. This is clearly shown in Plate CXIX, $\dot{B}$, a section through a pad of these exines.

SPORE-EXINES IN THE ILLINOIS COALS OF BEI) No. 6.

The Illinois coal from bed No. 6, as far as has been examined, contains a number of the different types of spores found also in most coals, but there seems to be no predominant type. One type of spore, however, seems to be characteristic in the vein, and to predominate in the Sesser coal. It is an exine of medium size, between 30 and 40 microns in diameter, slighly triangular in shape; irregularly sculptured, and with thick walls. The isolated spore is shown in Plate CXII, 7, and a cross section of the same type still embedded in the coal in Plates XC, $A$; XCVI, $B$; XCVII, $B$; CIV, $B$; and $\mathrm{CV}, A$ and $B$. Other types characteristic to this bed may possibly be discovered later. Spore-exines with long blunt spines (Pl. CXI, $A$ and $B$ ) and a type of large nutlike exine (Pl. CXII, 4 and 6 ) have been found only in these coals.

\section{THE CARBONACEOUS MATTER.}

The carbonaceous, or more highly carbonized matter, or the darker and more opaque matter, present in all coals, occurs in many forms. 
Two kinds are usually recognized. One has definite structure and clearly represents highly carbonized parts of cells or small groups of cells and bits of tissues, and is, therefore, anthraxylon and humic; the other is irregular and disorganized and of uncertain, though plainly organic, origin; no cell structure is evident. In sections of ordinary thickness the particles of both kinds range from opaque to barely translucent and are dark red. In very thin sections most of the particles are translucent and dark red. The irregular particles are generally the less translucent and also the more abundant.

When a coal is dissolved by means of the Schulze method, that is, if the reaction is not carried too far, these constituents remain behind, together with the spore-exines and cuticles, and in this condition their nature is best studied.

\section{THE MORE HIGHLY CARBONIZED ANTHRAXYLON.}

The identity of the carbonaceous anthraxylon particles is not readily established in the cross section, except when they appear as larger groups of cells or bits of tissues, but, on the other hand, it is easily determined in horizontal sections in which the carbonaceous particles are common. In some sections there may be only a few, but in others many are present, as shown both in the sections and in the residue after a dissolution of the coal in Schulze's reagent. They may have had their origin in any plant that contributed to the coal and may either be of chollenchymatous or parenchymatous origin, usually the former. As already intimated, they may consist of only a fragment of a cell or fiber or tissue, or of groups of fragments (Pl. LX, $A$ ). When fragments of cells, they range in size from the most minute particles to whole cells or fibers. When in groups they range from a few cells to a large part of a tissue (Pl. LX, $B$ ), and in the latter state form charcoal or "mother coal." All the photographs, both of vertical and horizontal sections, show this component in one way or the other.

The cell structures in the carbonized anthraxylon are nearly always well preserved, often as well as in petrified wood or in living plants, and all the cell characters known, such as spiral and sclerenchymatous thickenings, bordered pits, etc., are easily recognized. When in the shape of cells or group of cells the walls usually have retained much of their natural shape.

The finer carbonaceous matter of this class also is nothing more than finer particles or smaller fragments of the common charcoal or " mother coal."

\section{THE DISORGANIZED CLASS OF CARBONIZED MATTER.}

The more irregular opaque bodies are not so easily defined. These are apparently of divers origins and occur in a variety of forms and 
shapes. Some are irregular, others almost spherical, with all possible gradations between. In size they range from microscopic particles to those visible to the eye; the former being more numerous. A large portion of them are clearly more highly carbonized resinous matter; the origin of others is uncertain. The more spherical particles suggest resinous matter. (Pls. L, $A$; LII, $B$; LIII, $A$; LIV $B$; $\mathrm{LXV}, B ; \mathrm{LXIX}, B ; \mathrm{LXXIX}, A$; and LXXX, $A$.) Some are porous or vacuolated; others appear as nodules of combined mineral and organic matter or semipetrified. Although in medium thin sections they may be opaque, in very thin sections they are translucent. The pyrite nodules present in all coals, are absolutely opaque no matter how thin the section.

The carbonaceous matter seen so characteristically at a magnification of 1,000 diameters, has the same general nature as that seen at lower magnifications. But it should be understood that much of the fine matter, shown in many of the photographs at a magnification of 1,000 , and approaching the limit of visibility, is of mineral origin.

RODLETS.

From time to time attention has been called to certain components designated "rodlets " or "needles." In vertical sections, especially in vertical sections for opaque observation at low magnification, these appear as black glistening spots, usually circular or oval, but some are crescent-shaped and some are irregular (Pl. XXII, $A$, and $\mathrm{Pl}$. XXIII.) Plate XXVIII, Plate XXXII, Plate XXXIV, $B$; and Plate $\mathrm{XXXV}, A$ and $B$, show the rodlets in horizontal cleavage surfaces.

These rodlets usually occur in two different ways, either lodged in the attritus seemingly independent of any woody tissue or structure, or associated with definite structure or anthraxylon pieces of coal.

RODLETS SCATTERED THROUGH THE ATTRITUS.

Although these rodlets are scattered promiscuously through the coal they are particularly abundant in some horizons in the attritus. When a piece of coal is split along a horizontal cleavage plane through such layers, many needlelike bodies, parallel to the bedding plane in every conceivable direction are exposed on both surfaces of the fracture. (Pl. XXXV, $A$ and $B$.) The rodlets differ in length and thickness, in various layers and to some extent in the same layer or fracture; that is, in some layers they are all fine, occasionally very fine and of microscopic thickness, but still differing from each other in thickness. In another layer they may be thick and coarse, also varying in thickness within the layer, or again they may be of medium thickness, but thick, thin, and medium rodlets are 
rarely found together in one layer. Occasionally they are uniformly thick, some almost cylindrical, others tapering, some straight, others curved, irregularly bent, or crooked; some semicylindrical or roughly so, but all differ greatly in length and seem to be short pieces of longer bodies.

RODLETS ASSOCIATED WITH WOODY STRUCTURES.

When associated with woody structures rodlets are a definite part of the structure, always lying parallel to the woody fibers; in other words, they are a part of the piece of anthraxylous coal in which they are formed. They vary in thickness like the rodlets scattered in the attritus. Their length depends entirely on the size of the piece of the anthraxylon in which they are found. Similar rodlets are found in the so-called charcoal in similar relationship. ${ }^{a}$

CHARACTERISTICS OF THE RODLETS.

The rodlets are nonresinous, do not fuse, and do not swell on heating, and when they burn at all thev do not burn with a sooty flame. Their exterior surface is rather rough and dull, but when broken they reveal a smooth, jet black, glistening fracture. They are brittle, and break with a conchoidal fracture. Some are dense and solid, others more or less spongy. They are rich in quartz, and are petrified or semipetrified or composed of a mixture of finely divided organic or coaly matter and quartz. Some, in fact, consist entirely of silicious matter, some having a central core of quartz surrounded by a thinner or thicker coat of semicarbonaceous matter, in some the carbonaceous matter is more or less crescent shaped in cross section. Usually, however, the whole rodlet is composed of petrified matter. The rodlets may be composed wholly of quartz or contain only a small amount, but the proportion of quartz is, on the whole, very high. The rodlets can easily be removed from the coal, and with a hot flame the organic matter may be entirely burned out leaving a snow-white silicious matter, which is of a delicate spongy nature and varies in amount and texture according to the proportion of the original components. When the silicious content is relatively small the structure of the residue is very delicate, and when the silicious content is very high, the residue is solid.

Although many rodlets have exterior markings, no definite organized markings, such as pits, spirals or trabaculae, have been observed on the rodlets. When exterior markings are present they consist of small irregular hollows, irregularly situated. Frequently, however, these are arranged in rows, quite closely packed, resembling pits of tracheae. (Pl. CLVI.)

${ }^{a}$ White, David, Resins in paleozoic plants and in coals of high rank: Prof. Paper 85-E, U. S. Geol. Survey, 1914, pp. 75-76. 
THE ORIGIN OF RODLETS.

During the coal-forming period the plants contributing to the coal deposits were chiefly Lepidodendrons, Lygenodendrons and Medullosae. The siems of these plants were woody cylinders or rings of wood or xylem. In the center of the stems in some was a large core of pith, and surrounding the ring of wood was a thick cylinder of cortex consisting mainly of a pith-like tissue. In the stems of others, as Heterangium Grievii, there was no pith, but the whole central part was occupied by a vascular or woody cylinder composed throughout of irregular anastomosing groups of tracheae, interspersed with strands of parenchymatous or pith-like tissue; and the central cylinder of wood was surrounded by a thick cortex.

In other forms, as the Medullosae, several, usually three, solid vascular cylinders, close together were surrounded by a common cortex, (Pl. CLI, A). In all of them the wood was divided into wedges by broad rays consisting of parenchymatous tissue. The cortex of all these forms was pervaded by numerous leaf traces. Strands or bundles of vessels issuing from the vascular cylinders would turn upward before entering the leaves, run up into the cortex a considerable distance and finally run outward into the leaves. In some of these forms the cortex was traversed by numerous mucilage canals, that closely resembled the mucilage canals of the living cycads. A correct idea of the structure of these stems may best be obtained by examining the stem of a fossil Medullosa. Plate CLI, A, represents a cross section of the stem of Medullosa anglica, the only stem so far found in this country. In the central part of the stem the three vascular cylinders, each with its central primary wood are visible $(\mathrm{px})$. Inclosing the three vascular cylinders is a common periderm (p), outside of this is the inner cortex (ic) and surrounding this again is the outer cortex (oc). Although the cortex of this specimen was much disorganized and pyritized, both the mucilage canals and the leaf traces may be distinguished. Plate CLI, $B$, Plates CLII, and CLIII, are radial sections through the cortex and part of one of the steles of the same stem, showing the mucilage canals $(\mathrm{m})$ and the leaf traces (lt) in the parenchyma (ic). At (oc) may be observed sclerenchymatous strands in the outer cortex.

In Plate CLIV, $A$ and $B$, both showing coal from Shelbyville, there is a very close resemblance to the appearance of the radial sections of the Medullosa stems. The lighter parts ( $p$ ) are clearly shown to be parenchymatous tissues; in this are embedded vascular strands (vs), closely resembling the vascular strands of leaf traces in the fossil Medullosa, and slender needle-like bodies $(\mathrm{m})$ that closely resemble the contents of the mucilage canals of the same specimen. These needlelike bodies resemble in every particular the 
dlets found throughout the coals. Similar woody patches are comon in almost every coal. Woody components containing rodlets are idently not all of the same species, as a number of different types ntain rodlets.

Plate CLV shows a woody patch from the Zeigler coal. In this ecimen the vascular tissue consists of rather broad bands (vs), rereas the parenchymatous tissue consists of comparatively narw strands $(p)$. In this specimen the needles or rodlets are in the scular strands. Some rodlets are embedded in the parenchyitous tissue as far as can be determined by the pieces left.

Several types, apparently different, are found, but details concern$g$ them is unnecessary. Enough has been shown to reveal the intity of some of the rodlets and to show that the mucilage canals the Medullosae and related forms are one source of rodlets.

FUNGI.

Bodies resembling the hyphæ and spores of fungi have been found all of the coals examined. Fungi have positively been identified the coal from the Vandalia mine. (Pl. CLVII, $A$ and $B$.) The phæ are found only in the anthraxylon strips, which in some secins are densely crowded with them. Their habits seem to have been xch like those of certain fungi that infest the wood of recent plants. re hyphæ run largely parallel to the fibers of the wood, and premably in the lumina, but penetrate the walls of the fibers at right gles (Pl. CLVII, $A$ ), a characteristic habit of recent fungi. Freently they radiate irregularly from a common center. (Pl. VII, B.) Sporelike thickenings are often observed, as shown the photographs just referred to, and are similar to those found woody peat.

Sporelike bodies have been found associated with spore-filled orangia in the coal of the experimental mine. A part of such a orangium is shown in Plate CLVIII, $A$, at a magnification of 150 meters, the sporelike bodies being visible among the spore-exines. ate CLVIII, $B$, and Plate CLIX, $A$ and $B$, taken from different rts of the sporangium at a magnification of approximately 1,000 meters, show the same bodies more distinctly. The tissue of the orangium is well preserved on one end and almost lacking on e other. On the latter end are numerous indefinite threadlike dies, presumably hyphæ. The sporelike bodies occur in largest mbers in the semistructureless region, as shown in the photographs. e evidence is not sufficient for a positive conclusion, but the bodies question probably are fungi. 
OTHER ORGANISMS IN COALS.

Other bodies that deserve notice are shown in Plate CLX, $A$ and $E$ These are of an unknown origin, and their general nature may bes be learned from the photographs. The individual body is roundec but slightly wedge-shaped, and a number of these, either 9 or 11 often form a complete ring. Others are scattered separately throug the section. The organism is exceptionally small, the ring measurin between 7 and 9 microns and the individual bodies about 2 micron in diameter.

\section{COMPARISON OF THE STRUCTURES OF THE COALS.}

\section{THE COALS FROM THE PITTSBURGH SEAM.}

The coals examined from the various localities from the Pittsburg seam, have similar structure and composition, and their constituen are of similar origin. There is a slight difference in the proportior of the various constituents, also in the general appearance, color an opaqueness, physical condition and chemical nature of the coal i the different localities. The latter is especially noticeable in con paring coals from the western and eastern parts of the field. Th: concerns the physical and chemical nature of coal, and is mentione incidentally.

Of the coals examined from the Pittsburgh bed, that from tr. Oak mine and the experimental mine are nearest alike. That fros Madison and the so-called Pittsburgh coal, picked up from coa delivered in Pittsburgh for domestic purposes, differ from th Oak mine and the experimental mine coals in that the attritus richer in carbonaceous matter and the anthraxylon is slightly les translucent and is darker red. However, in thin sections the anthraz ylon is vitreous, clear, and transparent in all four coals. The a tritus in the Madison and the Pittsburgh coal appears darker o account of the large proportion of carbonaceous matter. In ser tions or layers of the coal where the carbonaceous matter is absen the attritus looks like that of the other two coals.

The coal from the Connellsville region is markedly different fror the others. Its anthraxylon is a much darker red and far less tran: lucent. The difference between the various anthraxylon strips, plain in the other coals, has been lost and the strips can be di tinguished from one another only with great difficulty. The grea est difference exists in the attritus. In a casual microscopic exa ination and even a fairly careful examination, the attritus seems contain no spore-exines nor resinous matter and to be composed humic matter' only. In a close and careful examination, evident the spore-exines at one time were in exactly the same proportion 
in the other coals, but in some way have been largely eliminated. Only a few whole spores are faintly recognizable; usually only residues or vacant places are seen where were once spore-exines. The humic matter has become more opaque and can not be detected from the resinous matter. ${ }^{a}$

The Connellsville coal has not been exhaustively studied, but its original composition clearly was much like that of Pittsburgh coal and the coal from other localities. Also, the spore-exines still remaining are of the same type as those from other parts of the bed.

\section{THE COAL FROM CARBON HILL, ALABAMA.}

The coal from Carbon Hill is more like the normal coal from the Pittsburgh bed than any other coal examined, but the predominant spore-exines differ from those of the Pittsburgh coal or those of any of the other coals examined.

The most striking characteristic of the Carbon Hill coal is the relatively large proportion of well-preserved tissue among the smaller anthraxylon components. Such chips as are shown at 6-a in Plate LXXXIV and $4-a$ in Plate LXXXV are common in every section. The anthraxylon strip at 1-a, Plate LXXXVII, is more homogeneous and much more compressed. Nevertheless, the cell structure was clearly discernible under the microscope and is recognizable to some extent also in the photograph.

The humic matter shown at 1-d to 3-d in Plate LXXXIV and in the whole of Plate LXXXVI is greatly comminuted and a relatively little spore matter and carbonaceous matter is present. Plate LXXXVIII, $B$, an area included in Plate LXXXVIII, $A$, at a magnification of 1,000 diameters, represents the groundmass of the attritus in which the spore-exines and other smaller constituents are embedded. Most of the spore-exines are relatively large and thinwalled; only a few seem to be small and thick-walled. The groundmass as shown in Plate LXXXVIII, $B$, is largely granular; it consists of carbonaceous, earthy, and humic matter, besides a substance resembling spore matter which probably is the degradation product of cuticular matter.

It should be remembered that the particles or objects represented in such photographs are exceedingly minute. For instance, no sporeexine shown in this photograph is more than 3 microns, or $0.003 \mathrm{~mm}$., thick. The groundmass shown in other sections may consist of carbonaceous and earthy matter and a larger proportion of "humic" matter, or may be derived from the woody parts of plants, some of it in the shape of small fragments or particles and some approach-

a The truth of this statement is still under investigation and will be discussed more fully in a paper on "Differences of coking and noncoking coals," now in preparation.

125536 ${ }^{\circ}-20-$ Bull. 117 $\longrightarrow 7$ 
ing an amorphous state. The photographs show also a matter lighter in color intermixed with the others.

\section{THE ILLINOIS COAL.}

In structure and general appearance the Illinois coal differs considerably from the Pittsburgh coal. The former has a far greater number of the larger anthraxylon components, much less of the highly carbonized matter, and a smaller proportion of the attritus. Consequently the anthraxylon components are more closely packed, often piled one immediately upon the other, without any of the other constituents that usually form part of the attritus separating them, although they are usually separated by thin layers of spores or by cuticular matter. The different pieces of anthraxylon, being but poorly differentiated in color or other characters, are not always readily distinguished from one another under the microscope. Cuticles, which form but a very small part of the Pittsburgh coal, are prominent in these coals, and another tissue, consisting of lightcolored, thick-walled, irregularly folded cells, usually associated with cuticles and found only rarely in the Pittsburgh coal, is also proninent in the Illinois coals. Such a tissue is well shown at 3-d, Plate XCII. $B$; at $3-$ d and $t-\mathrm{d}$; Plate XCIII, $B$; Plate XCIV, $A$ and $B$; Plate CX. $A$; and at a very high magnification in Plate CX, $B$.

\section{THE ZEIGLER COAL.}

The photographs of the coals from the Zeigler mine well illustrate the group. Plates XCII to XCVII give typical cross sections from the Zeigler coal. Plate XCII, $A$, represents an anthraxylous strip in which the original tissue is greatly compressed and rendered homogeneous, yet inclusions in the cells are distinctly recognizable at the region $5-$ a. At $1-$ a a number of thin strips have been intimately united; at $3-\mathrm{a}$ is a woody tissue containing pale, flattened cells. The rounded and irregular black spots that are particularly abundant and noticeable in the upper part, 1-a, are pyrite nodules. These nodules readily break into numerous fine particles, and in the process of making the section are often scattered across it in strealss, which are prominent in the photographs.

At 1-a in Plate XCII, 13 , is shown a bit of anthraxylon characteristic of this group. The original cells are compressed into very thin, straight striae. In a horizontal section the woody structure is distinctly recognized as seen in Plate XCIX, $B$. The remainder of Plate XCII, $B$, represents a strip of coal composed of woody and resinous matter arranged in thin sheets alternating with cuticles, spore-exines and the remains of a tissue of pale, irregularly folded cells mentioned in the preceding paragraph. This tissue is particu- 
larly well represented at the level $3-d$, but is also visible in other parts of the photograph. A similar layer is represented in Plate $\mathrm{XCIV}, A$. It is here more irregularly layered and present in larger proportion. This tissue resembles the cork layers in bark, and is termed cork-like or corky tissue, although its origin has not been definitely determined. Leaf cuticles are also prominent, whereas spore-exines are relatively few. The anthraxylon matter, $2-\mathrm{a}$, is seen compressed into straight striae.

Plate XCIV, $B$, shows another characteristic appearance of these coals. Anthraxylon, cuticles, corky tissues, spore-exines, and resins are all represented. Plates XCV and XCVI and $\mathrm{CV}, B$, represent, at a magnification of about 1,000 diameters, areas included in the section shown in Plate XCIV, B. Plate XCV, $A$, is an enlarged area in the middle of the level $1-\mathrm{d}$, of Plate XCIV, $B$. The white areas across the middle of the photograph represent the cork-like tissue. Carbonaceous matter, at the top, woody matter, and thin spore-exines are all readily distinguishable. Plate $\mathrm{XCV}, B$, represents an area included in Plate XCIV, $B$, in the middle of the level 6 -d. Spore-exines, cuticles and anthraxylon matter are distinguishable. The cell structure of the anthraxylon component in the lower part of the photograph, a part of the anthraxylon component at 7-a, of Plate XCIV, $B$, is here shown at higher magnification. Plate XCVI, $A$, at a magnification of 1,000 , is taken from the same section, lout just outside of the area represented by Plate XCIV, $B$. Plate $\mathrm{XCVI}, B$, and Plate $\mathrm{CV}, B$, at 1,000 diameters, also from the same section, show in cross section the thick-walled spore-exine sparingly represented in these coals, but predominant in the Sesser coal. Plate XCVII, $A$, magnified 200 times and Plate XCVII, $B$, magnified 1,000 times, from an area included in the former, show considerable resinous matter besides the usual constituents. The area 2-sp of Plate XCVII, $A$, explains the striated appearance seen at low magnifications in Plate XXIV, $A$. This is much better illustrated in Plate XCVIII, $A$ and $B$, magnified 200 times, representing laminæ largely composed of the residue of leaves and leaf cuticles. The heavy, more or less zig-zagged white lines represent the cross sections of leaf cuticles, and the matter between them, largely the residue of leaf tissues.

\section{THE HART-WILLIAIMS COAL.}

So far the normal appearances of these coass have been shown. Certain layers are found that are chiefly composed of spore-exines and more highly carbonized matter. Such a layer is shown in Plate LXXXIX, $A$, magnified 200 times, from coal from the HartWilliams mine. Plate LXXXIX, $B$, magnified 1,000 times, represents an area included in the former. The fine, scattered, highly car- 
bonized matter is distinctly shown in this latter photograph, and the humic or anthraxylon matter is also resolved into finer particles. At the bottom, the strip of anthraxylon about 15 microns thick is solid, but still shows evidences of cell structure.

\section{THE SESSER COAL.}

In certain respects the Sesser coal differs considerably from the coals just discussed. The anthraxylon components are more comminuted and contain considerably more resinous and carbonaceous matter and fewer spore-exines and cuticles. Woody structure is preserved about as well as in the coals of the Hart-Williams, Benton, and Zeigler group. $\Lambda$ heary-walled spore-exine distinctly predominates but is not found in this coal exclusively.

A characteristic appearance of the Sesser coal is shown in Plate CIII, A, magnified 200 times. At the area $1-\mathrm{d}$ is a considerable amount of resinous matter, some humic matter more or less comminuted, and a few spore-exines. The anthraxylon strips 2-a and 4-a include a thin sheet comprised of a tissue several cells thick of definite and well-preserved plant cells. The woody layer at 6-a also shows more or less cell structure, much obscured. Plate CIII, $B$, and Plate CIV, $A$, both magnified 200 times, also are characteristic. A considerable proportion of the matter shown is clearly of woody origin, as indicated by the fine striations, which are a sure criterion of a woody origin, especially when seen at higher magnifications. Much of the comminuted matter looks quite homogeneous under ordinary microscopic examination, a characteristic of resinous matter. However, resinous matter usually is rounded or oval, whereas the matter shown here is decidedly angular. More highly carbonized matter may be noticed scattered throughout the coal, but relatively little spore matter is visible. Plates CIV, $B$, and $\mathrm{CV}, A$. represent small areas of this coal at a magnification of 1,000 diameters; the predominant thick-walled spore-exine is embedded in an anthraxylous débris mingled with some carbonaceous and some earthy matter.

\section{THE ROYALTON COAL.}

The Royalton coal, although in general much like the other Illinois coals, differs from them in certain respects. Its anthraxylon components reveal well-preserved cell structure; much of it exceptionally well preserved. Its spore-exine content is a little higher than in the Hart-Williams, Benton, and Zeigler group, and it contains more highly carbonized matter. Its chief characteristic is its broad, relatively thin, anthraxylon components, or chips, which are often separated by definite sheets of attritus, and give the cross section under the microscope a shredded look. Cuticles are abundant in some 
layers, and accompanying them are the pale-thick-walled, irregularly folded and layered cells predominant in the Zeigler coal. (Pl. CX, $A$ and $B$.)

The photographs illustrating the coal from this section have been chosen from a wide range of samples, and like those of other coals, are intended to represent general conditions.

Plate CVI, $A$, is a layer rather rich in spore-exines and finely comminuted humic matter, with some resinous-looking matter scattered through it. The cross section of the anthraxylon chips at 4-a is characteristic. Plate CVI, $B$, shows a strip of anthraxylon with remarkably well-preserved tissue. Similar strips are quite prevalent in this coal. Resinous bodies may be observed in the level 1-d.

Plate CVIII, $B$, at a magnification of 1,000 diameters, represents a more highly magnified portion of Plate CVIII, $A$, in the level 3-d. The spore matter consists both of whole spore-exines and of fine fragments, the latter being common, though not prevalent. The anthraxylon strips, although very thin, still show some cell structure. Plate CIX, $A$, shows considerable opaque carbonized matter interlayered with the anthraxylon strips. Plate CIX, $B$, a more highly magnified portion of the section included in Plate CIX, $A$, at the level 2-a, shows the remains of woody structure that prevail everywhere. On casual observation the anthraxylon strips represented in these photographs seem homogeneous, but at higher magnifications and proper lighting and screening the structure is brought out clearly. The irregular bands in Plate CIX, $B$, show matter rendered dark by earthy and carbonaceous matter intermixed.

Much of the Royalton coal reveals the same general appearance as the Zeigler coal, as shown in Plate CX, $A$ and $B$, and needs no further discussion.

\section{THE BUXTON (IOWA) COAL.}

The general nature and structure of the coal from Buxton, Iowa, is shown in Plate CXXI, $B$, and Plate CXXII, $A$. Some horizons are woody and contain few spores, others are woody and resinous, others contain a large proportion of spore-exines and relatively little woody matter, and still others contain a large proportion of spores mixed with much earthy matter or with carbonaceous or resinous matter. This coal also contains numerous minute nodules of pyrite, so irregularly distributed that some thin laminæ are composed chiefly of them, while other laminæ contain few. Cuticles also form a large proportion in this coal, anthraxylon sheets and cuticles alternating in close succession in many layers.

Plate CXXIV, $A$, shows a characteristic layer of cuticles, anthraxylon, and resinous matter. Plate CXXXVI, 5, shows how many of the isolated cuticles look. Plate CXXIV, $B$, shows layers 
of débris containing a few spores, a large proportion of finely comminuted anthraxylon or humic matter, and a medium proportion of earthy and carbonaceous matter. In $3-\mathrm{sp}$ is a part of a sporangium, with well-preserved cell structure, inclosed in a cuticle, and containing a few spore-exines in the central part. Plate CXXV, $A$, shows an area containing a large proportion of resinous matter, besides strips of anthraxylon matter, comminuted anthraxylon matter, sporeexines, and earthy and carbonaceous matter. In Plate $\mathrm{CXXV}, B$, are the same elements, but the earthy and carbonaceous matter form a very large proportion. Plate CXXVI, $A$, shows a more anthraxylous section, common in this coal. At the upper part at 1-a is part of a thicker piece of anthraxylon. Plate CXXVI, $B$, contains anthraxylon strips and intercalated resinous layers, a feature characteristic of this coal and of the coal from Vandalia, Ind.

The black irregular and circular spots scattered through this photograph represent pyrite nodules, such as occur from top to bottom of the bed. In Plate CXXVII, $A$, the layers consist chiefly of sporeexines, but also contain much earthy and carbonaceous matter which is characteristic of many layers in this coal. The spore-exines so numerous in the photograph are the predominant spores throughout this seam. The cross sections of the spore-exines are better seen in Plate CXXVII, $B$, magnified 1,000 times and taken from a section included in Plate CXXVII, $A$. Plates CXXVIII, $A$ and $B$, and Plate CXXIX are characteristic appearances of the Buxton coal in horizontal sections. The first two show much woody matter, the cell structure of which is plainly seen. Plate CXXIX, $A$, represents a portion through the attritus, showing spore-exines, humic matter, and carbonaceous matter. Plate CXXIX, $B$, is a more highly magnified portion of Plate CXXIX, $A$.

Sporangia, filled with spores and well preserved, often with the sporangium wall intact, are common in the Buxton coal (Pls. CXXI and CXXII). Whole cones, or parts of cones, in which are sporangia filled with spores still intact, are also common.

The anthraxylon components of the Buxton coal are clearly differentiated from one another by their colors; they are resinous and have a relatively coarse physical texture or loose micellar structure. The pieces are mostly flat and thin, but thicker and less numerous than in most coals. These characteristics are well shown in the photographs.

In cross section the cell structure of the anthraxylon matter does not seem to be well preserved, only occasionally are strips found in which the structure is clear, yet evidences of the cell structures are seen everywhere. In the horizontal sections, however, the cell structure is evident in every section. (Pls. CXXVIII, $A$ and B.) Plants with large cells seem to have played a prominent part in the formation of this coal, as it contains large isodiametric parenchy- 
matous cells. The cell walls are very much compressed and they now appear thin and poorly defined. It would seem that the decay of the wood had advanced far during the peat stage.

\section{THE VANDALIA (IND.) COAL.}

A casual examination of the Vandalia coal from Vigo County, Ind., in the block (Pl. CXLII), shows that it contains few of the larger anthraxylon pieces. For example, a lump of coal, about 10 inches thick, under examination contains only one anthraxylon layer about one-fourth of an inch thick, and only four or five pieces between one-eighth and one-fourth of an inch thick. More careful examination shows that the remainder of the coal is composed of innumerable thin sheets of anthraxylon, and that most of these are much less than an eighth of an inch thick, many of them being microscropic. The general nature of the components has already been shown by a cross section at low magnification and from horizontal cleavage planes. Horizontal cleavages expose patches of woody structure of a variety of sizes and shapes; although in many patches the pieces seem to be relatively long and broad, by far the largest number are less than an inch wide and long. (See Pls. XXY, XXVI, and CXLIII, $A$ and B.) Examined in opaque cross sections at lower magnification the coal is seen to contain relatively little microscopic débris, or attritus (Pl. CXLIII, $A$ and $B$ ), the bulk being composed of closely packed anthraxylon matter.

Examined in cross section at a magnification of 200 diameters (Pls. CXLVI to CL) the coal is seen to be composed of innumerable, closely packed, thin pieces of anthraxylon matter with relatively little of the fine microscopic matter or attritus; hence it contains relatively few spores. A dearth of spores is a characteristic of this coal.

Plate CXLVI, $A$, is a typical section. In the upper part, at $1-a$, is a relatively thick piece of anthraxylon; at $2-c$ is a laver contaïning a number of very thin cuticles; at $3-\mathrm{d}$ are thin anthraxylon strips with carbonaceous matter, including an occasional spore-exine between; at $4-\mathrm{a}$ is a sheet of light-colored anthraxylon matter that shows cell structure faintly; and at 5 -d is a thin layer consisting of anthraxylon strips with included carbonaceous matter and some earthy matter that give a dark color. The round and irregular black spots represent nodules of pyrite, common in this coal.

Plate CXLVI, $B$, is another typical appearance of the Vandalia coal; the anthraxylon strips at $1-\mathrm{a}$ and $4-\mathrm{a}$, and attritus at $2-\mathrm{d}, 3-\mathrm{d}$, and $5-\mathrm{d}$, contain a large proportion of spore-exines lodged in dark, macerated humic matter.

The anthraxylon throughout the coal is very resinous, and layers like those shown in Plate CXLVII, $A$ and $B$; Plate CXLVIII, $A$ 
and $B$, and Plate CXLIX, $A$, are common. Particularly common are anthraxylon components containing numerous resinous globules similar to those shown in Plate CXLVII, $B$, CXLVIII, $A$ and $B$, and Plate CXLIX, $A$, though usually with more of the original woody matter remaining than here shown. In the piece represented in Plate CL, $A$, much of the woody matter remains characteristically associated with the resin globules in situ; in other sections, as in Plate CXLIX, $A$, at 1-a, the remaining anthraxylon matter seems to have rotted away partly, learing little else but the resin, which is partly intact. Plate CXLIX, $B$, is an example. So completely has the woody tissue disappeared that the interstices between the resin particles are merely empty spaces.

When examined in cross section little of the original cell structure is clear; nerertheless evidences are seen by careful examination under proper lighting. In the horizontal sections, the structure may be recognized easily, as in Plate CXLV, $A$ and $B$, though in places it is difficult to detect.

The anthraxylon of the Vandalia coal has a loose micellar structure, as the photographs indicate, and is not as compact as that of the Pittsburgh coal. In this respect the Vandalia coal resembles the Buxton coal. The mottled appearance in the anthraxylon strips, 1-a, in Plate CXLVI, $A$, and $1-\mathrm{a}$ and $4-\mathrm{a}$ in Plate CXLVI, $B$, is due to this loose structure. If the photographs of the Pittsburgh coal are compared with them, the differences are readily seen. The Pittsburgh coal has a glassy and the Vandalia coal a spongy appearance. 


\section{PLATES I-CLX.}

\section{PLATE I.}

KIEL PEAT BOG.

. A bird's-eye view, from the east, of the peat swamp near Kiel, Wis. : foreground, an expanse of about 1 mile drained by the Sheboygan River, low cleared of trees and is covered with shrubs, grasses, and sedges. The ded peat swamp lies beyond this open area. The highland rising beyond wooded swamp is 3 miles distant.

$\therefore$ A near view of the interior of the same peat swamp. The trees are sfly white cedar (Thuya occidentalis), with here and there a tamarack rix americana) and a black ash (Fraxinus nigra). The hollows in the sground are tilled with water.

\section{PLATE II.}

\section{NEAR VIEWS OF PEAT BOGS.}

- A view in a peat swamp in Charlestown Township, Calumet County, - The growth consists primarily of the same plants as that in the swamp wn in Plate $\mathrm{I}, B$.

- A view in a peat swamp in Eaton Township, Manitowoc County, Wis. ice the uneven surface of the ground, density of the growth and the reclinpositions of a number of trees.

- A view in another part of the Eaton swamp in which the growth cons largely of young trees.

\section{PLATE III.}

\section{NEAR VIEWS OF PEAT BOGS.}

- A near view in the swamp near Kiel, Wis., shown in Plate I, B. The ace is covered with dead branches, twigs, leaves, and bits of wood.

A perpendicular view of the surface, a short distance from that shown - The litter on the surface consists largely of the leaves of the white cedar uya occidentalis), leaves of deciduous trees and shrubs, and twigs and ments of wood.

\section{PLATE IV.}

\section{A LUMP OF PEAT FROM A WOODY SWAMP.}

Natural size. A lump of peat showing small fragments of wood and ə cuticular matter embedded in the finer débris.

A small area, more highly magnified, between the fragments of wood lump of peat similar to the one shown above. 


\section{PLATE V.}

\section{SMOO'THED SCRFACE OF A LUMP OF PEAT.}

A horizontal smoothed surface of a lump of peat $(\times 10)$, showing bits of wood, seeds, and small bits of cuticles all embedded in the attritus.

\section{PLATE VI.}

\section{CHIPS OF WOOD FROM PEAT.}

Small fragments of wood separated from the lump of peat shown in Plate IV, $A$. Most of these pieces have been formed through exfoliation along the growth rings or through separation along the rays, are thin, flat chips that are hard when dried.

\section{PLATE VII.}

\section{CROSS SECTIONS OF WOODY PEAT.}

A. Cross section of one of the small fragments of wood shown in Plate VI. (X200.) The cells of the wood have collapsed during drying, and the walls have become contorted and folded.

B. l'art of the sime section shown above $(\times 1,000)$, showing the nature and form of the cell walls, and a few of the organisms found in peat.

\section{PLATE VIII.}

\section{ORGANISIIS IN WOODY PEAT.}

A. A lamina one cell thick $(\times 1,000)$, from fragment of wood shown in Plate Ir, $A$, showing the granular nature of the cell walis and certain large organisms prevalent in the woody peat.

B. Spores of a living ground pine (Lycopodium clacatum). $(\times 1,000$.) Note the relitively thick outer spore walls, or exines, corered with blunt spines. 


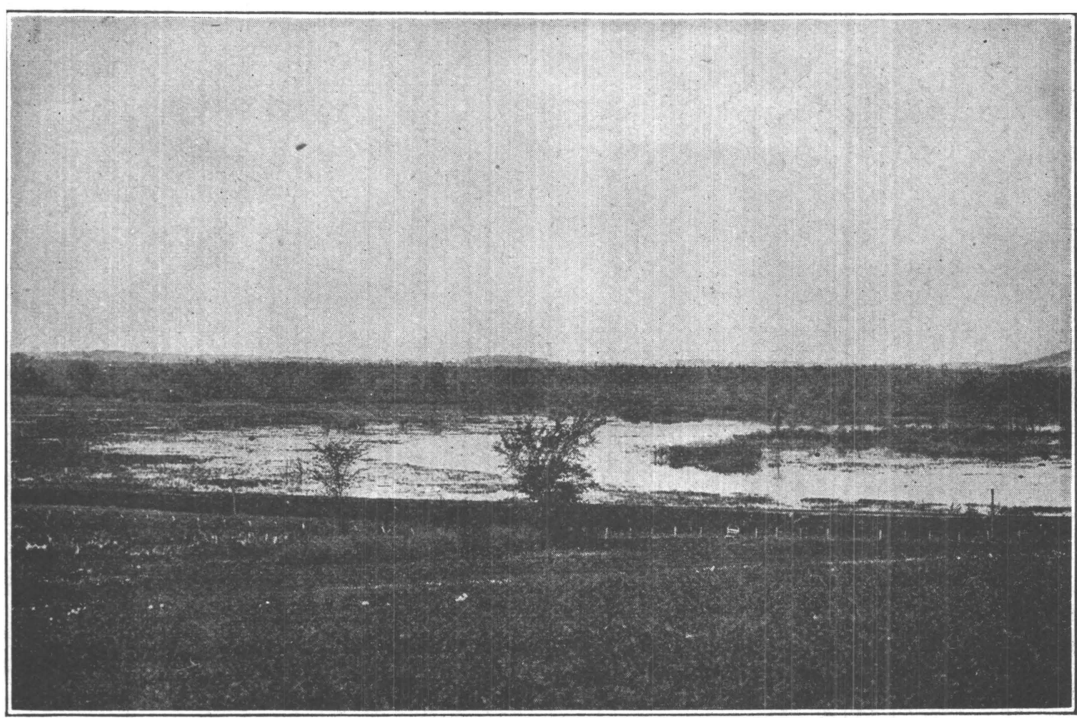

A. PEAT BOG NEAR KIEL, WIS.

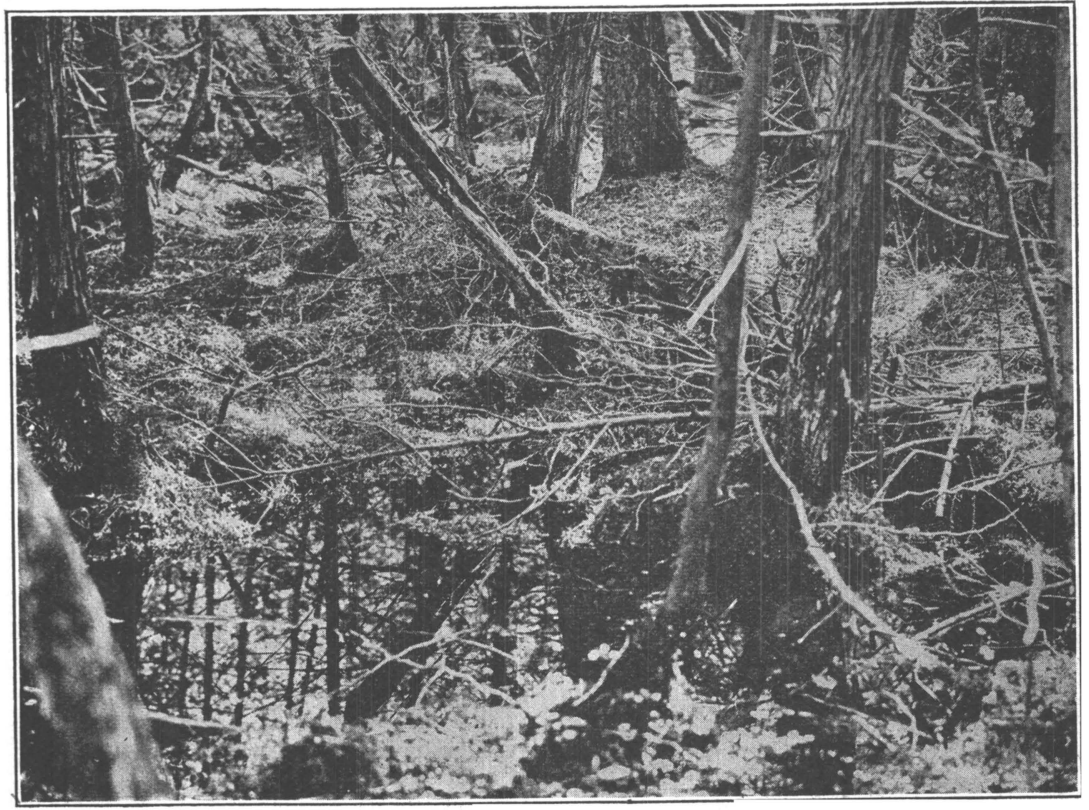

B. NEAR VIEW OF BOG NEAR KIEL, WIS. 


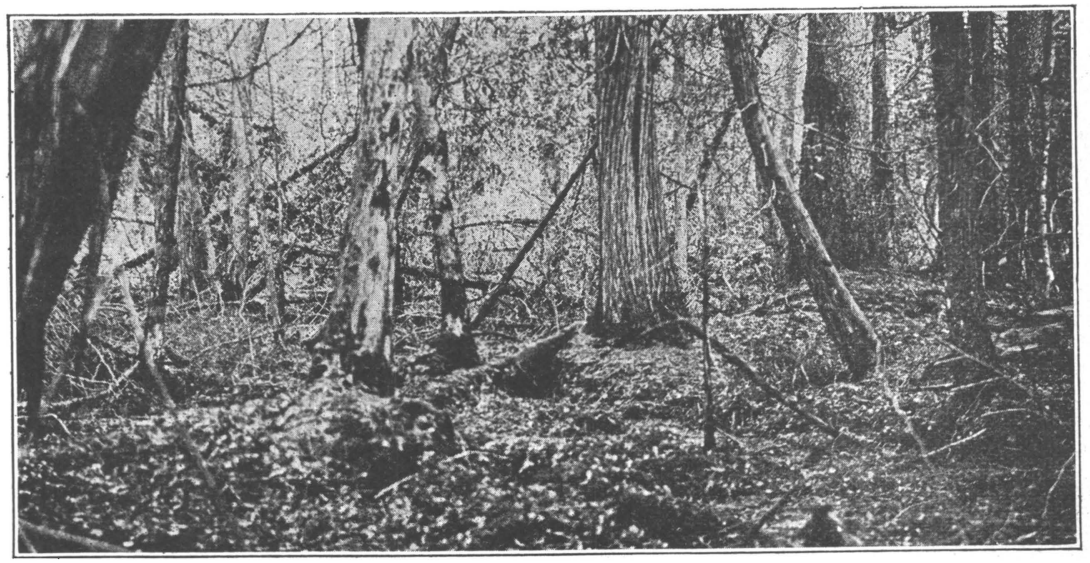

A. NEAR VIEW OF PEAT BOG IN CALUMET COUNTY, WIS.

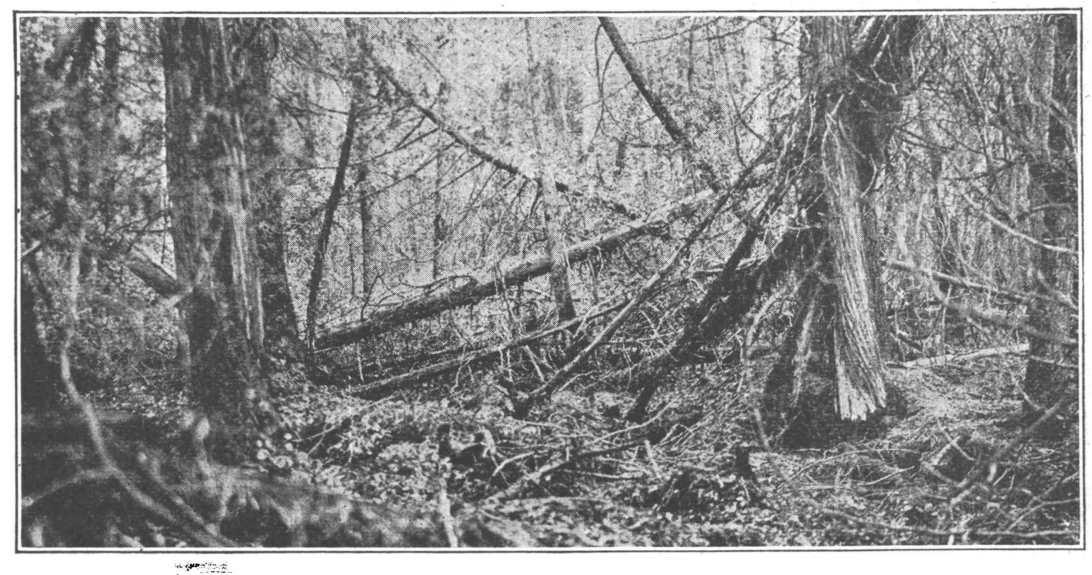

B. NEAR VIEW OF PEAT BOG IN MANITOWOC COUNTY, WIS.

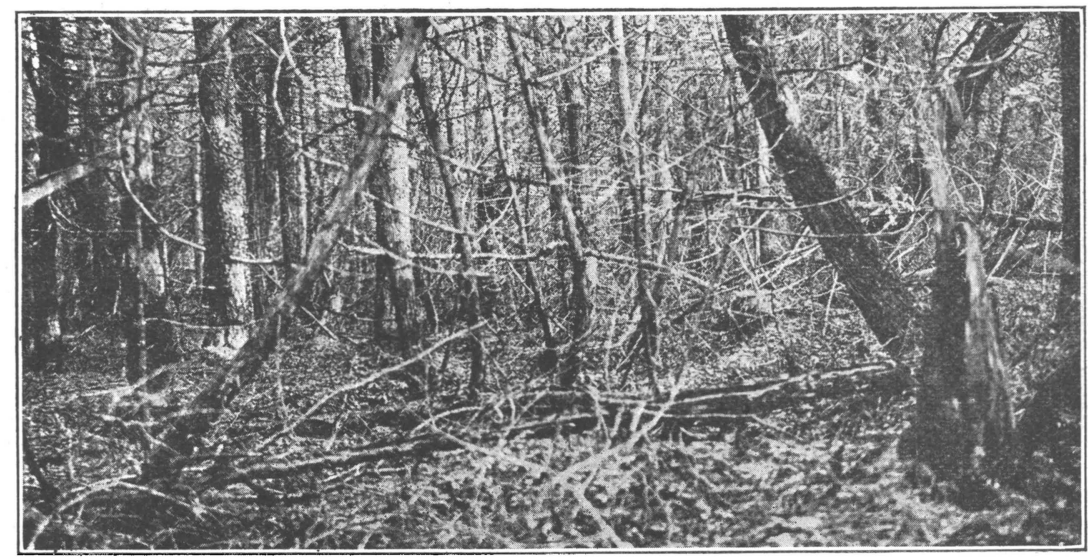

C. ANOTHER VIEW OF THE BOG IN MANITOWOC COUNTY, WIS. 


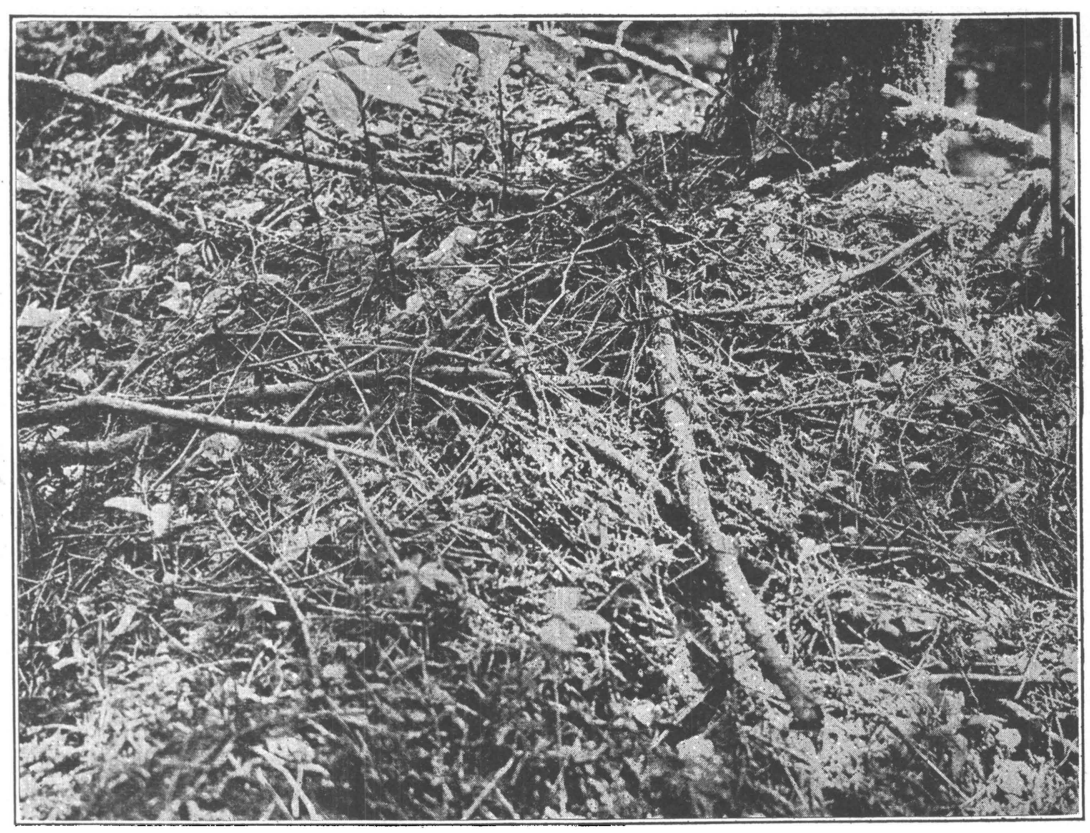

A. CLOSE VIEW OF THE BOG NEAR KIEL, WIS.

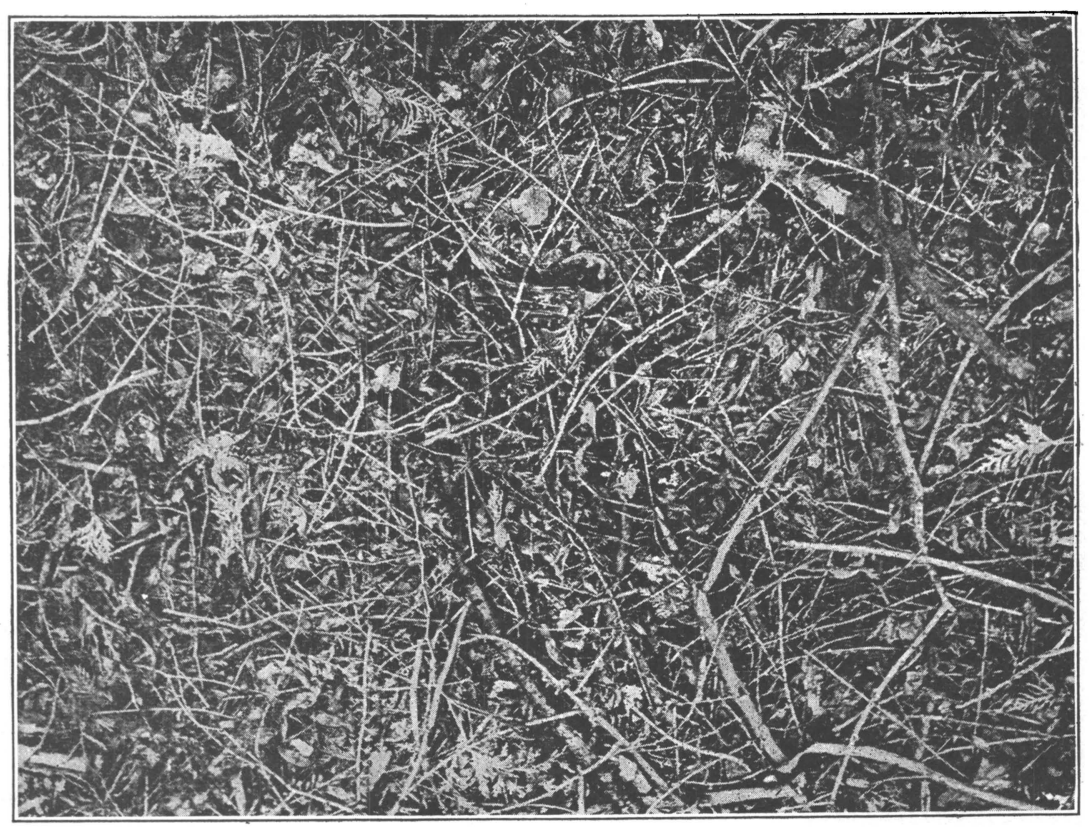

B. PERPENDICULAR VIEW OF SURFACE OF BOG NEAR KIEL, WIS. 


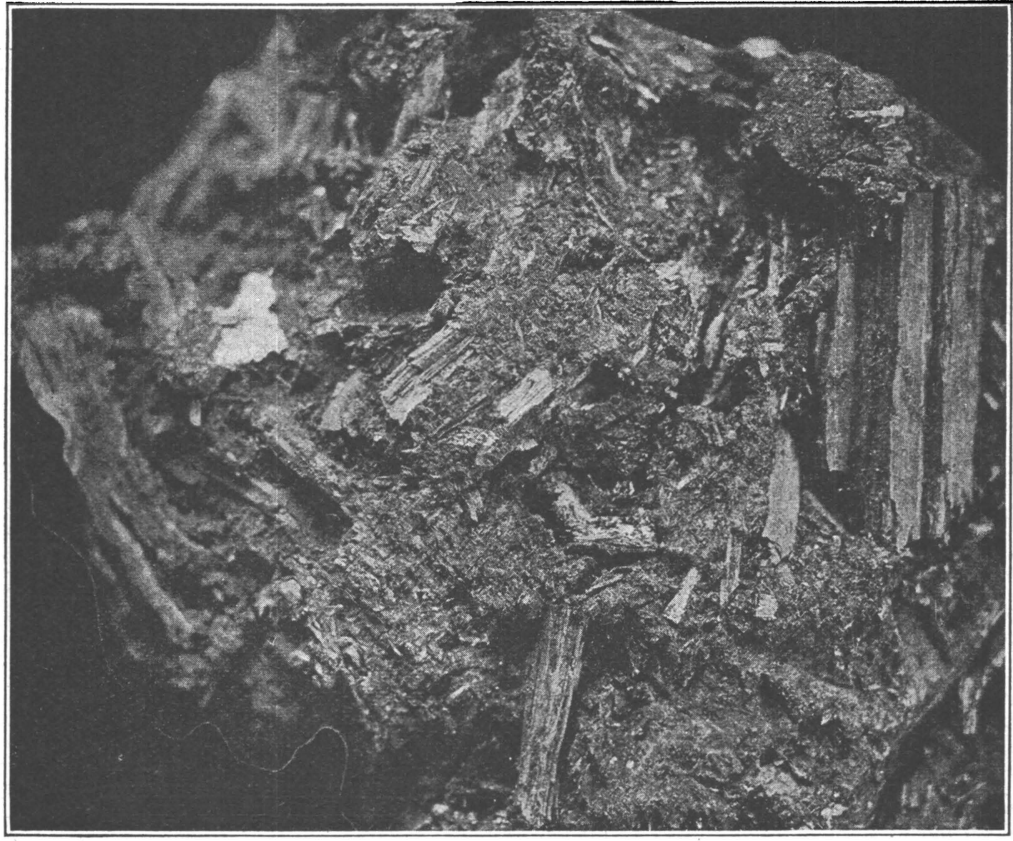

A. LUMP OF PEAT, NATURAL SIZE.

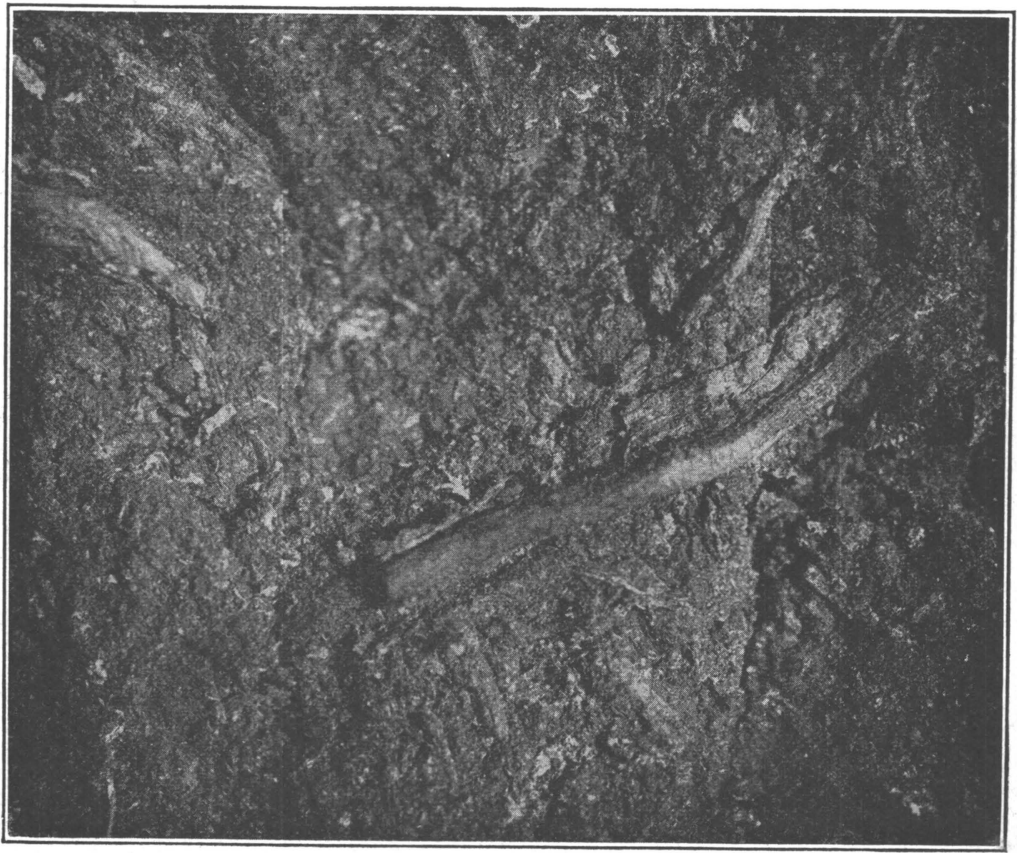




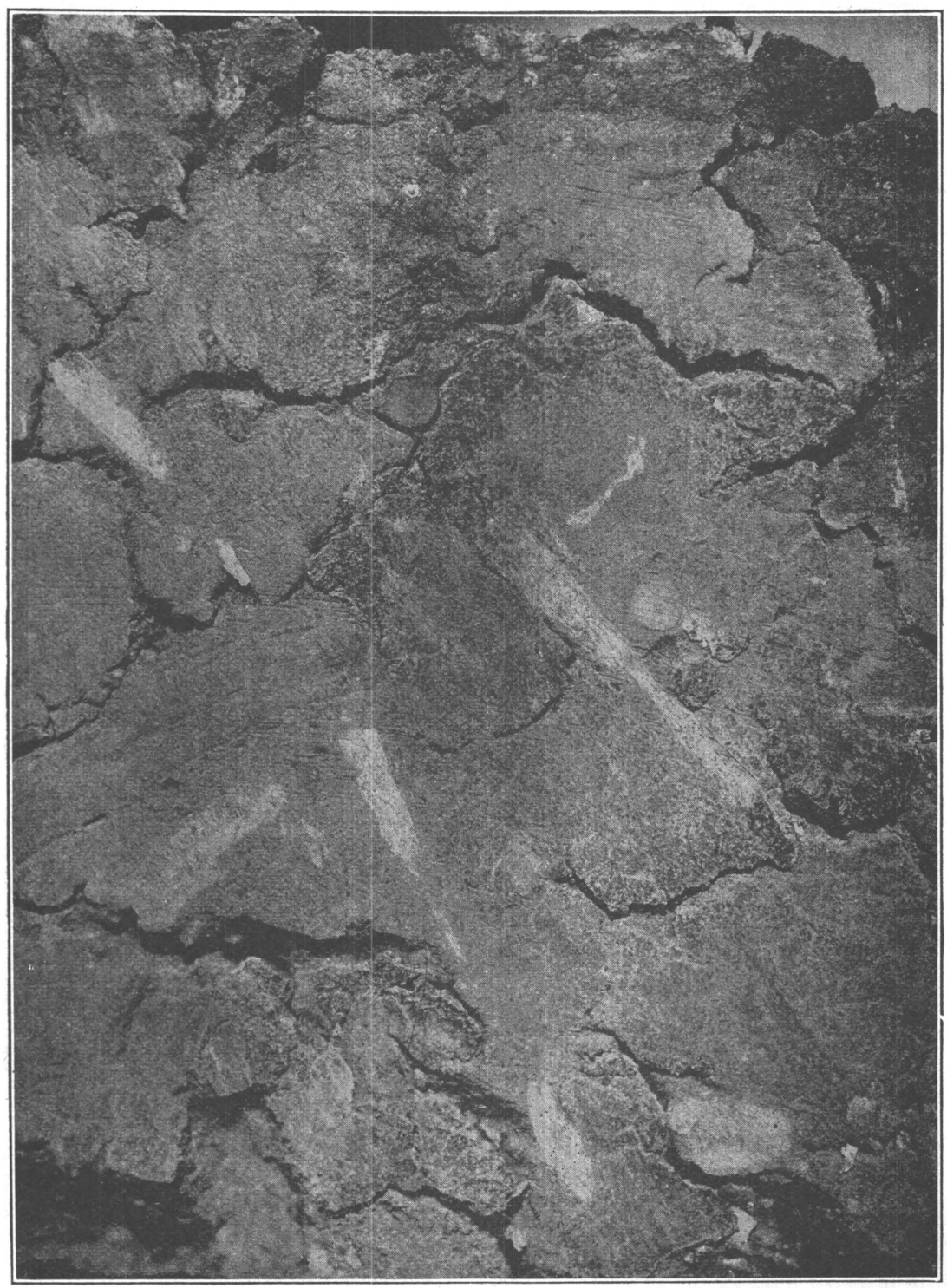

SMOOTHED SURFACE OF A LUMP OF PEAT. ( $X 10)$ 


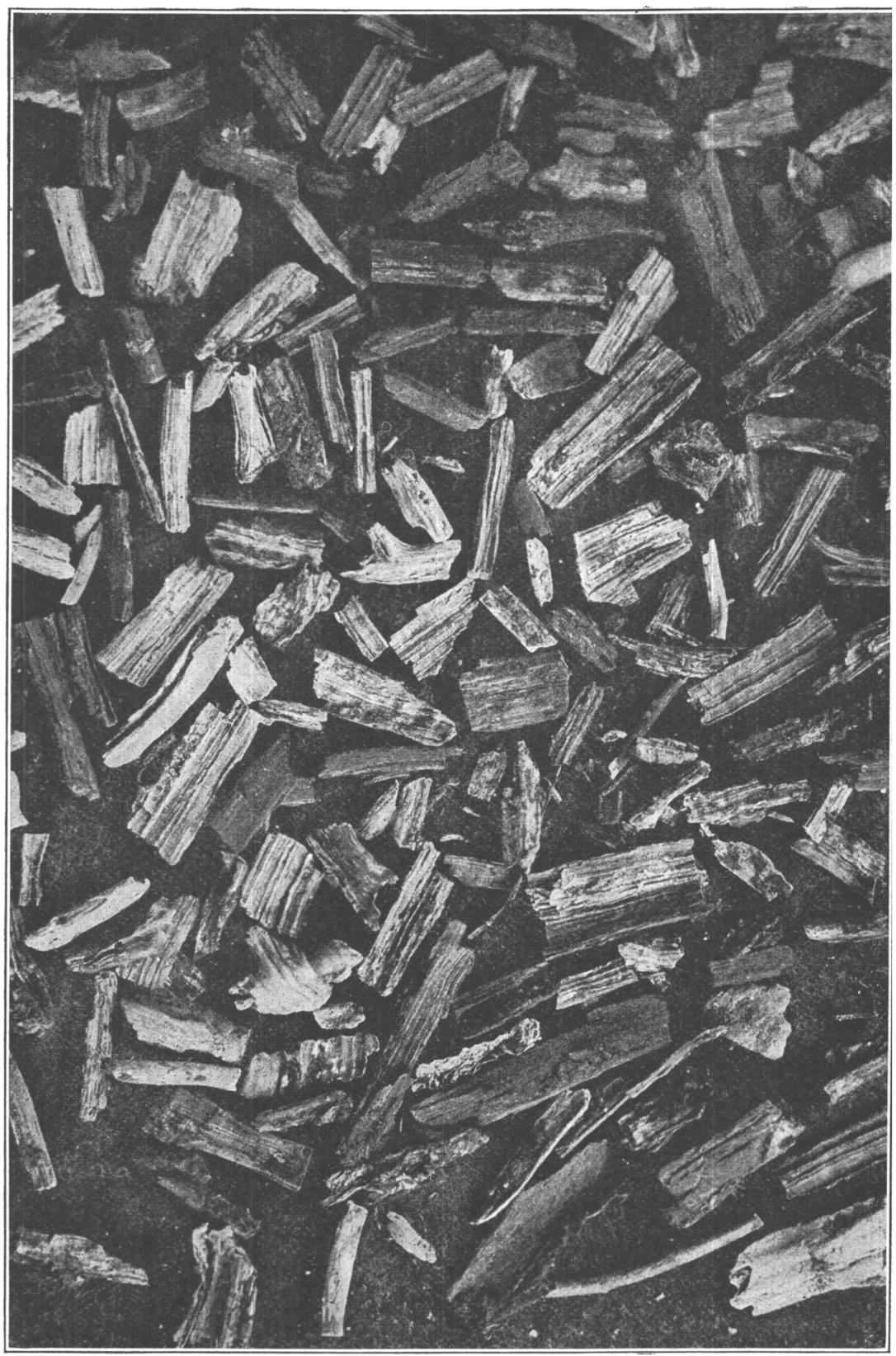

CHIPS OF WOOD FROM PEAT. 


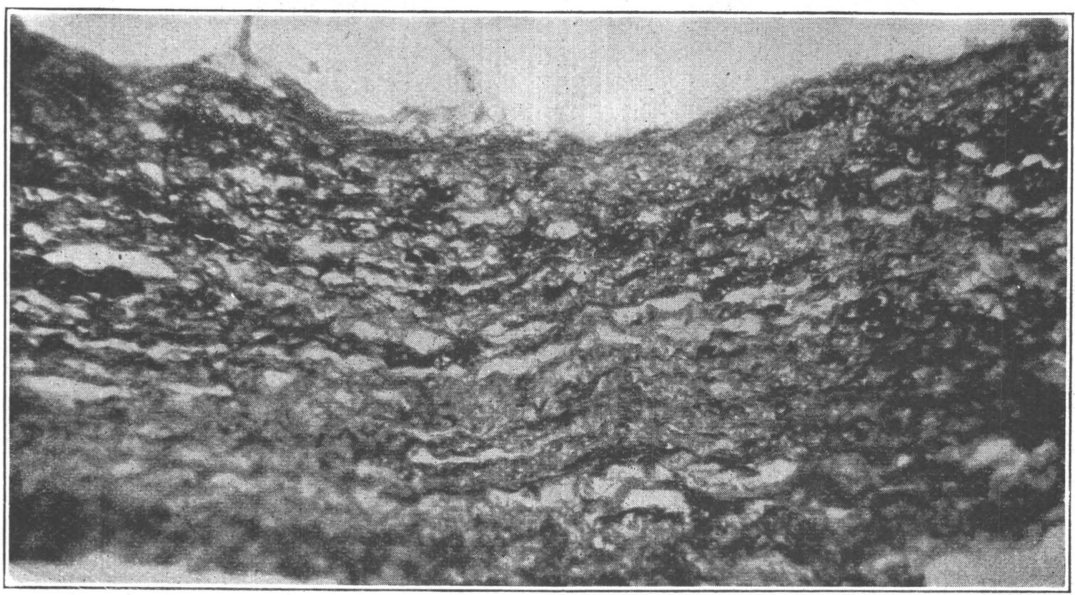

A. CROSS SECTION OF WOODY PEAT. (X 200)

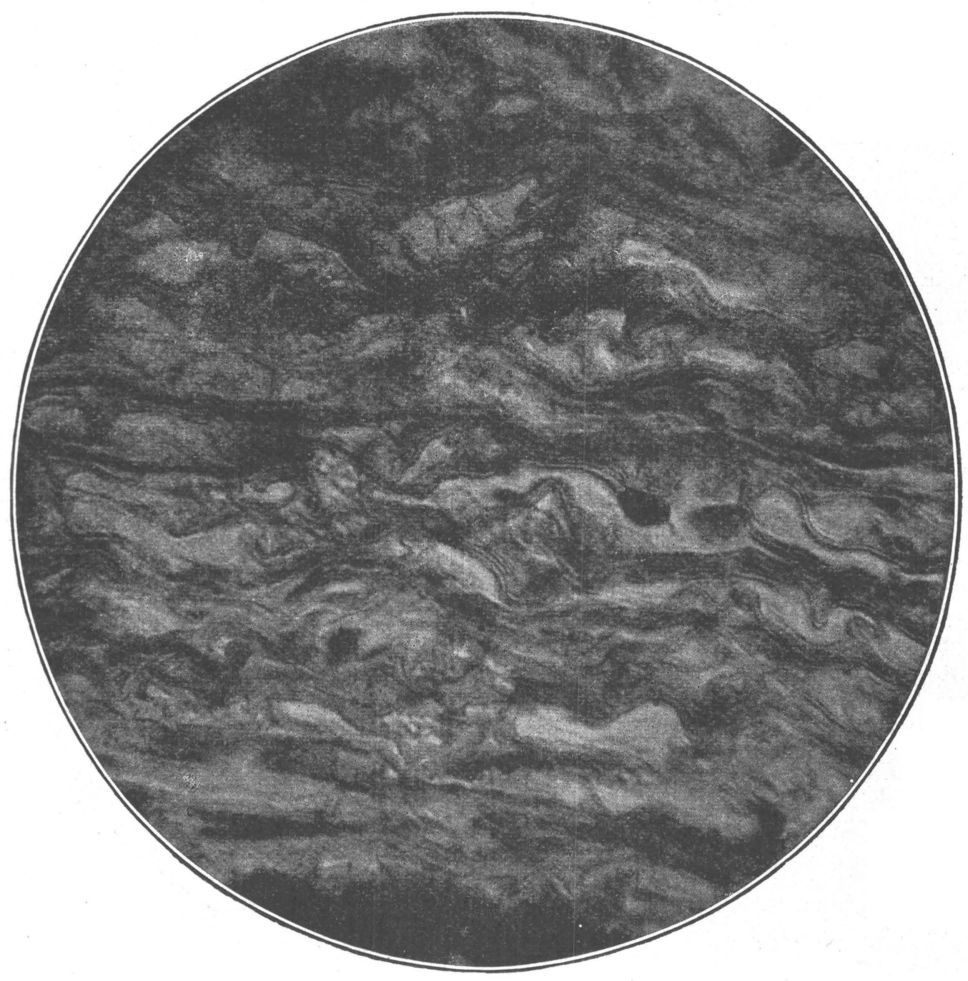

$B$. CROSS SECTION OF WOODY PEAT. (X 1000) 


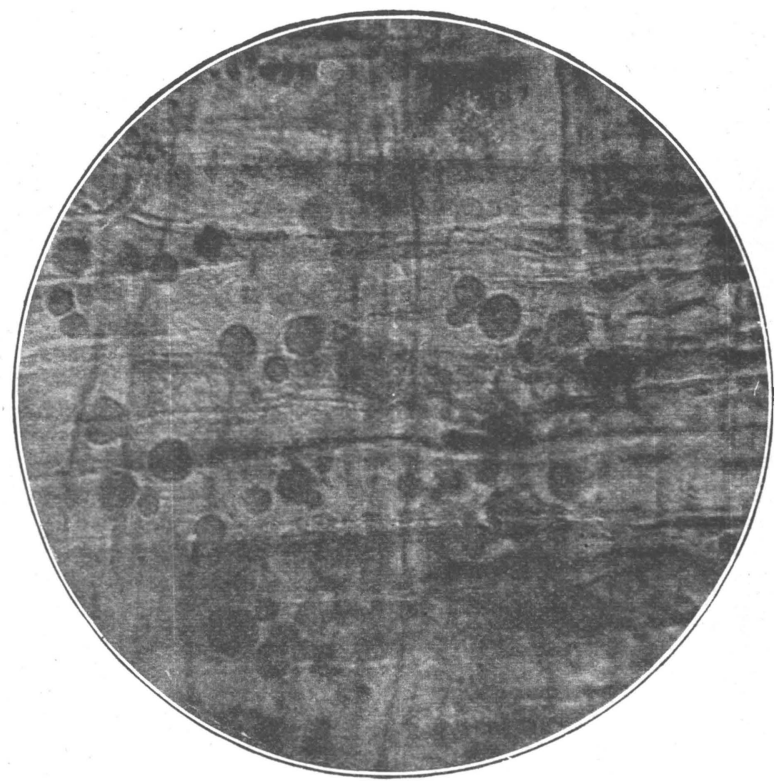

A. ORGANISMS IN WOODY PEAT. (X 1000)

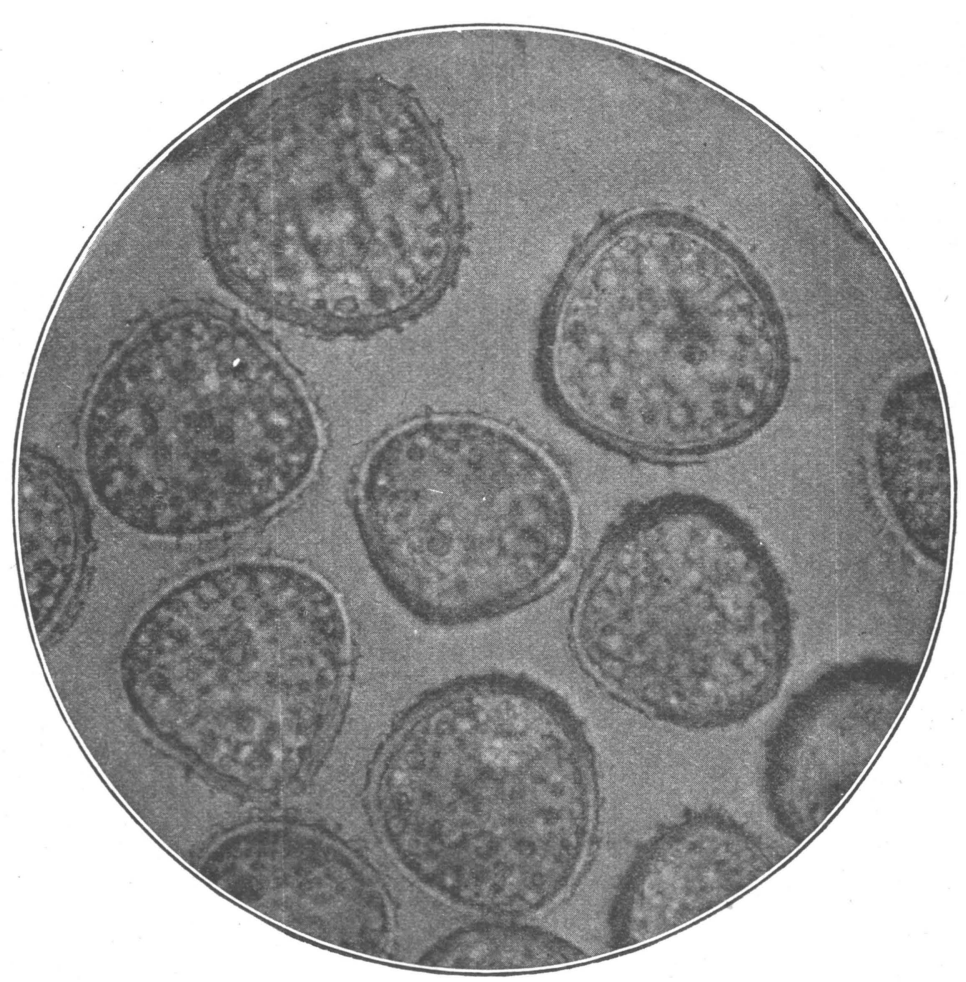




\section{PLATE IX.}

\section{CUTICles OF A CYCAD LEAF AND PINE NEEDLE.}

$A$. Part of the cross section of the leaf of a living Cycad $(\times 100)$ showing the general structure of the leaf. c, upper cuticle; h, hypodermal tissue; p, palisade cells; pa, leaf parenchyma; s, lower hypoderm containing stomata; $\mathrm{c}^{\prime}$, lower cuticle, very thin.

$B$. Part of a cross section of a living pine "needle." $(\times 100$.) Notice the conformation of the cuticle, $c-c$, to the underlying hypodermal tissue, $h-h$.

\section{PLATE X.}

\section{LUMP OF COAL FROMI SFSSER, ILL.}

A chunk of the coal from Sesser, Ill., showing the general laminations into "dull" and "bright" coal and the further sublamination of the "dull coal"; $a$ is the bright coal or anthraxylon components; $x-y$, the region in which the cleavage plane, shown in Plate XXX, is split.

\section{PLATE XI.}

\section{LUMP OF COAL FBOM BENTON, ILL.}

A. A piece of coal from the mine of the Benton Coal Co., near Benton, Ill., showing the general nature and lamination. a is the bright coal or anthraxylon components; $x-y$, the level of the horizontal fracture, fracture 1 , shown in Plate XXVIII, $A ; \mathrm{t}-\mathrm{u}$ the level of fracture 2, shown in Plate XXVIII, $B$.

$B$. The opposite side of the piece of coal shown in $A . \quad \mathrm{y}-\mathrm{z}$ indicates the level of fracture 1, shown in Plate XXVIII, $A$; $\mathrm{u}-\mathrm{v}$, fracture 2, shown in Plate XXVIII, $B$.

\section{PLATE XII.}

\section{LUMP OF COAL FROM BENTON, ILL.}

A piece of coal from the mine of the Benton Coal Co., representing a more "woody" or anthraxylous layer, as well as showing the general nature and lamination into the "dull" and "bright" coal, a represents "bright" coal or anthraxylon; d, "dull" coal; 1-a to 7-a and 2-d to 8-d indicate the "bright" and the "dull" coal, respectively, in the area cut off by the lines $x-x, y-y, n-n$, and $\mathrm{m}-\mathrm{m}$, and shown in Plate XV, from a polished surface. (Natural size.) co is part of a cone shown in Plate XIV. (Natural size.) 


\section{PLATE XIII.}

LUMP OF COAL FROM BENTON, ILL.

The opposite side of the same block is shown in Plate XII. d is "dull" coal; a, "bright" coal; co is a part of the same cone shown in Plates XII and XIV.

\section{PLATE XIV.}

CONE IN THICK VERT'ICAL SECTION.

An opaque cross section $(\times 10)$, viewed by reflected light, of coal from the mine of the Benton Coal Co.; 2 -co is part of an embedded cone shown in Plates XII and XIII, co. The lighter lines are the sporangium walls; the thicker gray lenses are a mass of spore exines; the irregular lines in black are part of the sporophyll tissues; $3-\mathrm{a}$ is a thicker anthraxylon component, and 1-d, a layer or débris not clearly differentiated in the illustration.

\section{PLATE XV.}

\section{A MAgNified AREA FroM PLATE XII.}

Polished area $(\times 10)$ mapped out by the intersecting lines $\mathbf{x}-\mathbf{x}, \mathbf{y}-\mathbf{y}, \mathbf{n}-\mathbf{n}$, and $m-m$, on the face of the block of the Benton coal shown in Plate XII, photographed by means of oblique illumination; 1-a, 3-a, 5-a, and 7-a are "bright coal" or larger anthraxylon; $2-d, 4-d, 6-d$, and $8-d$ are "dull coal"; $c$ is mineral charcoal.

\section{PLATE XVI.}

\section{A MAgNIFIED AREA FROM PLATE XIII.}

Area $(\times 10)$ of the Benton coal shown in Plate XIII. a, "bright coal"; $d$, "dull coal"; ms, a cross section of a megaspore. 


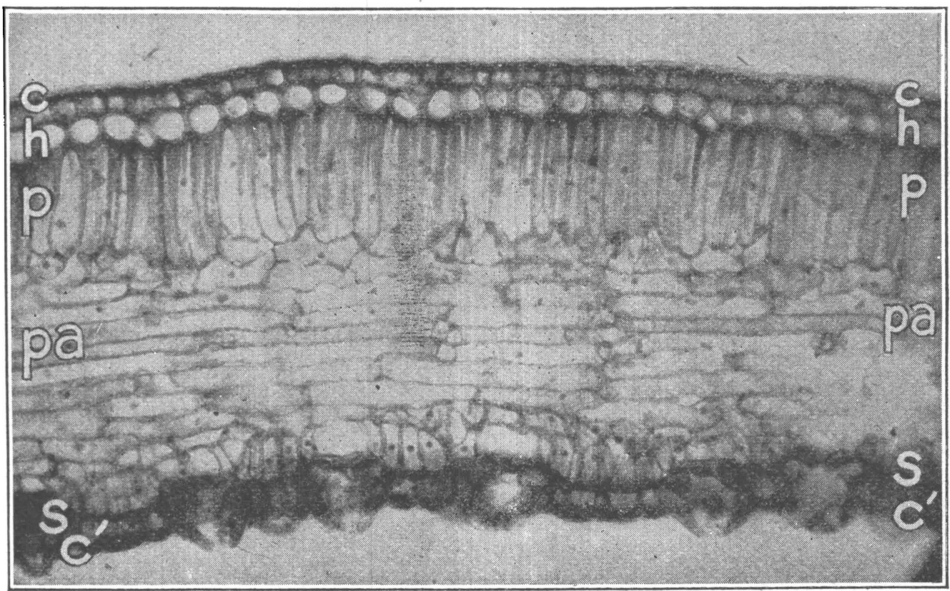

A. CROSS SECTION OF A LEAF OF A LIVING CYCAD. (X 100)

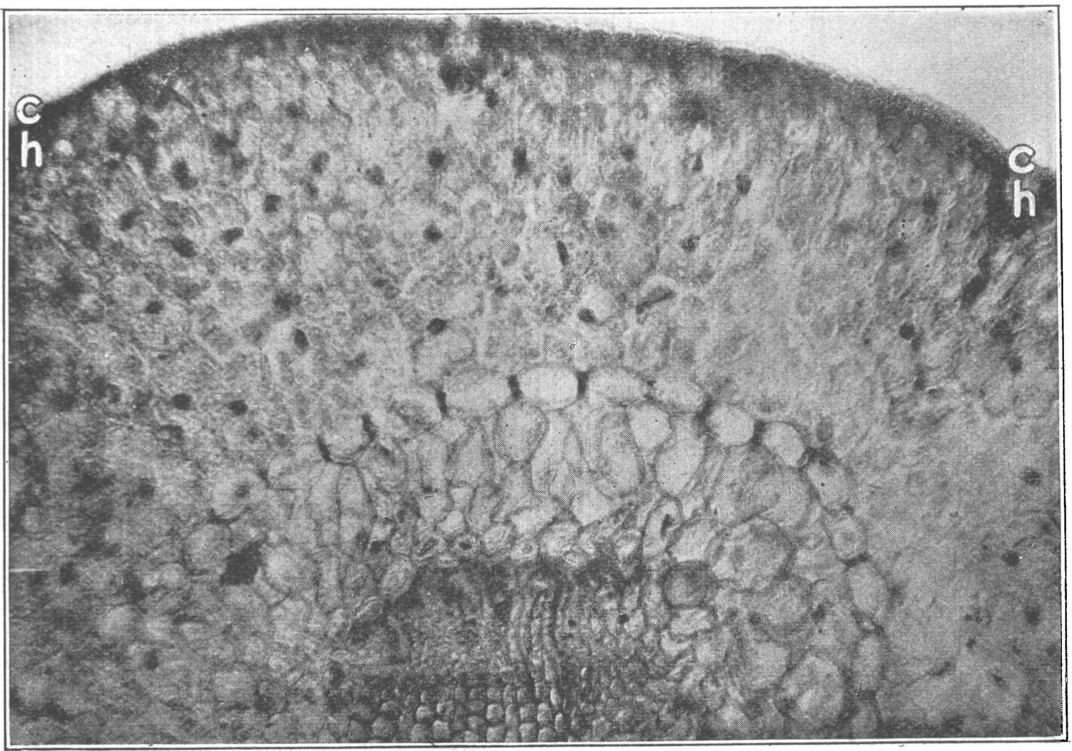

B. CROSS SECTION OF A LIVING PINE NEEDLE. ( $X 100)$ 


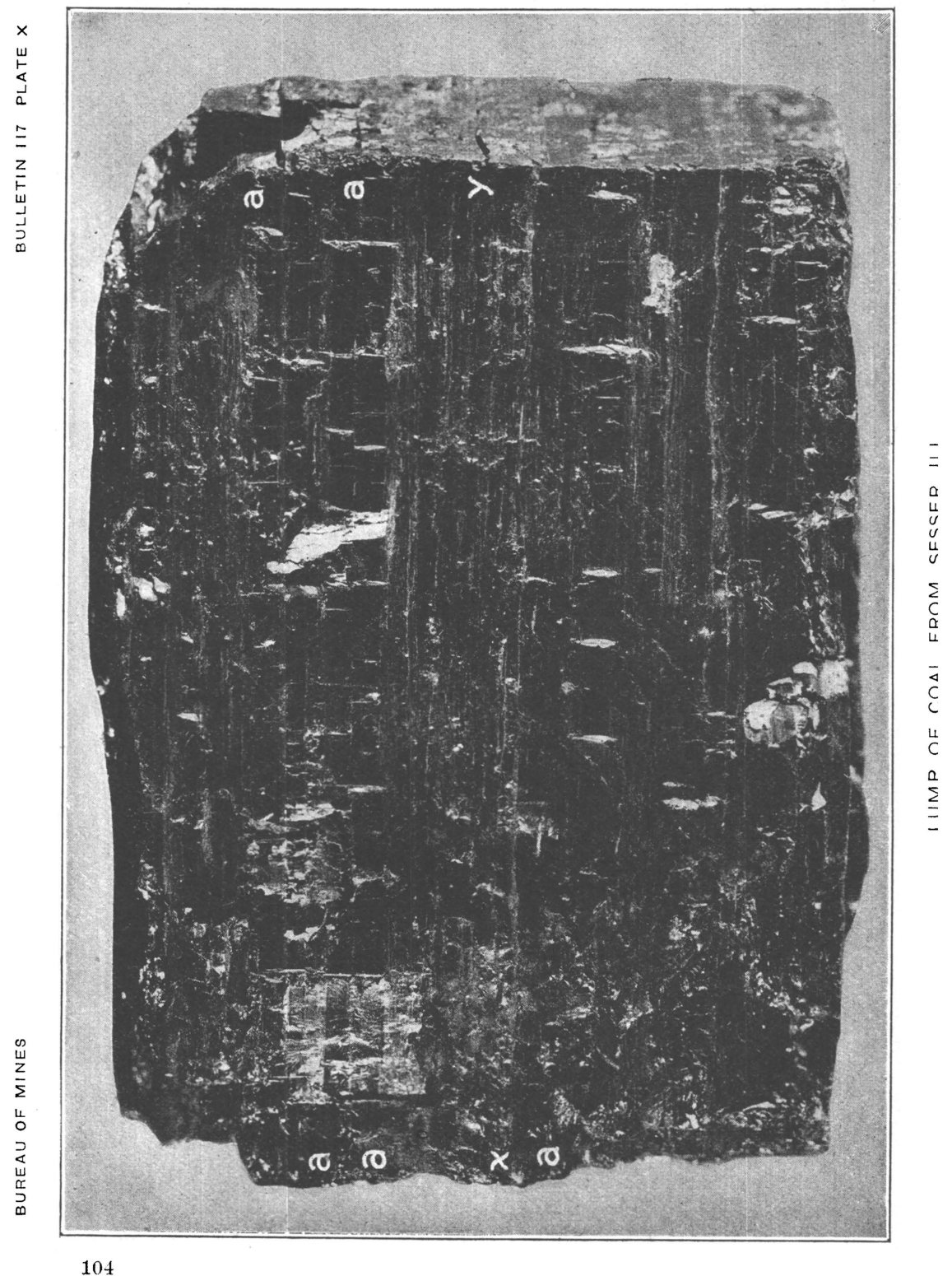




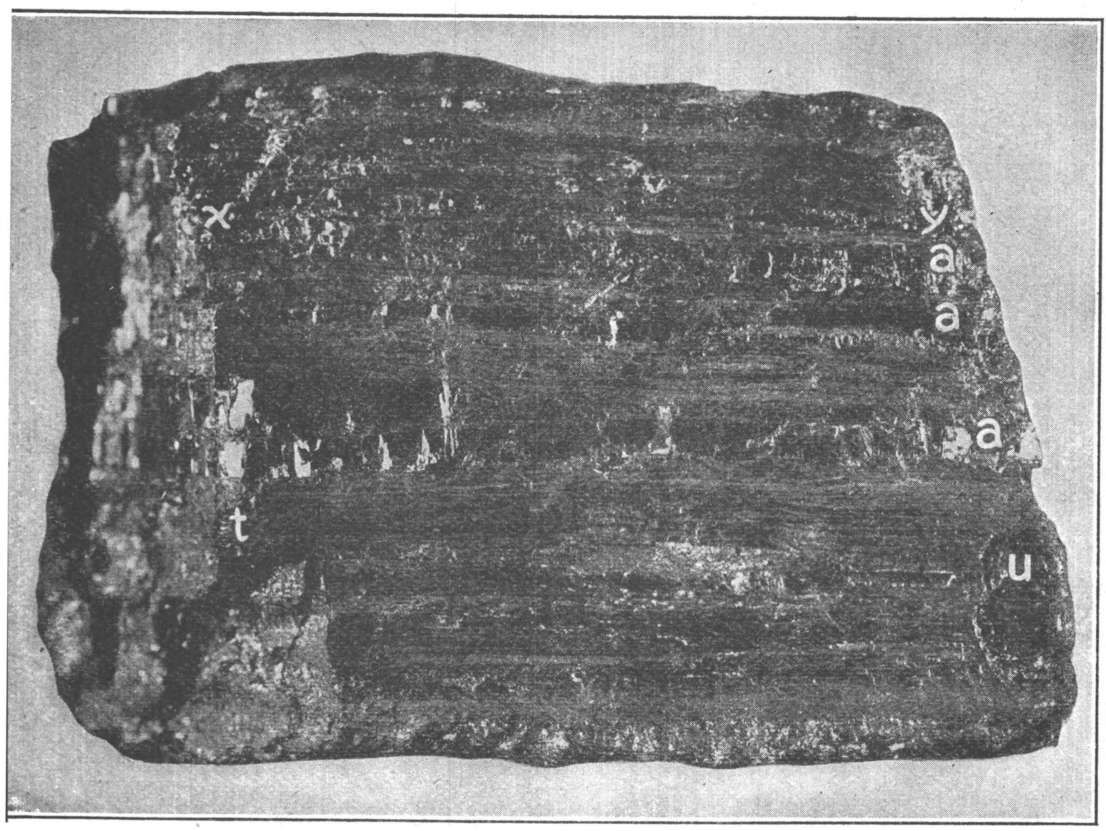

A. LUMP OF COAL FROM BENTON, ILL.

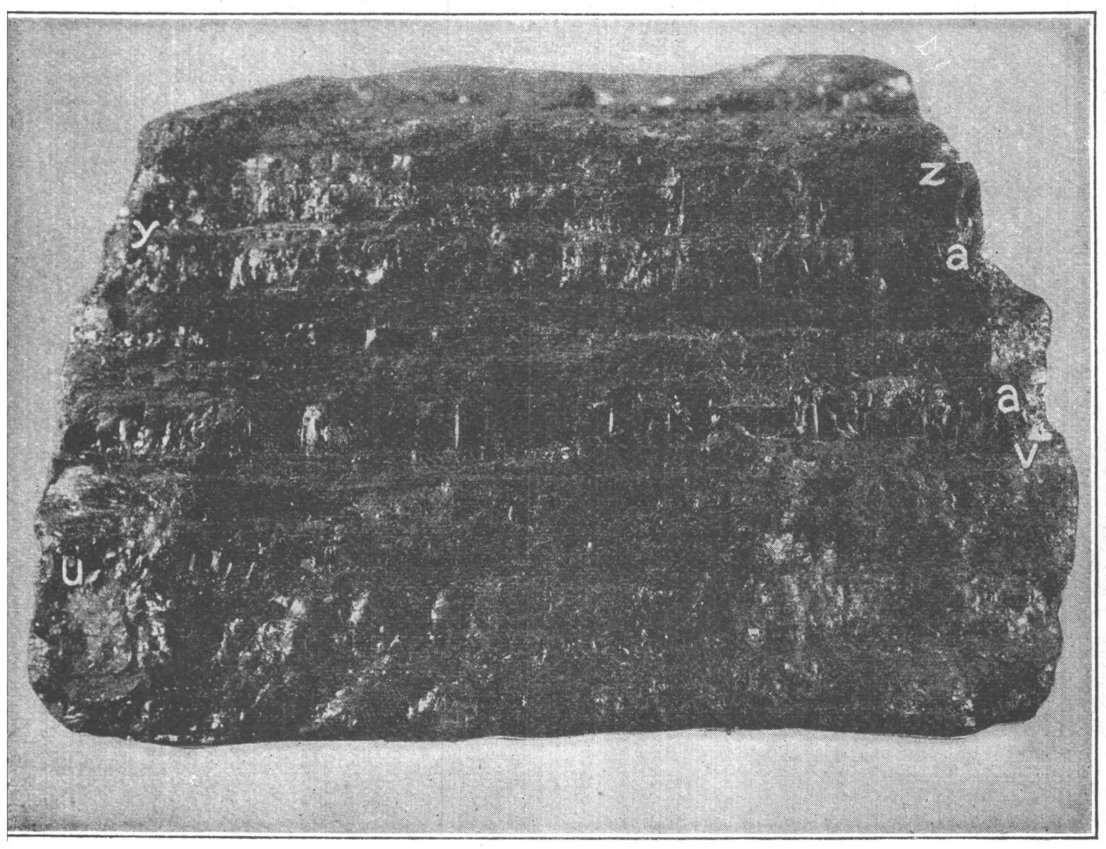

B. OPPOSITE SIDE OF LUMP SHOWN ABOVE. 


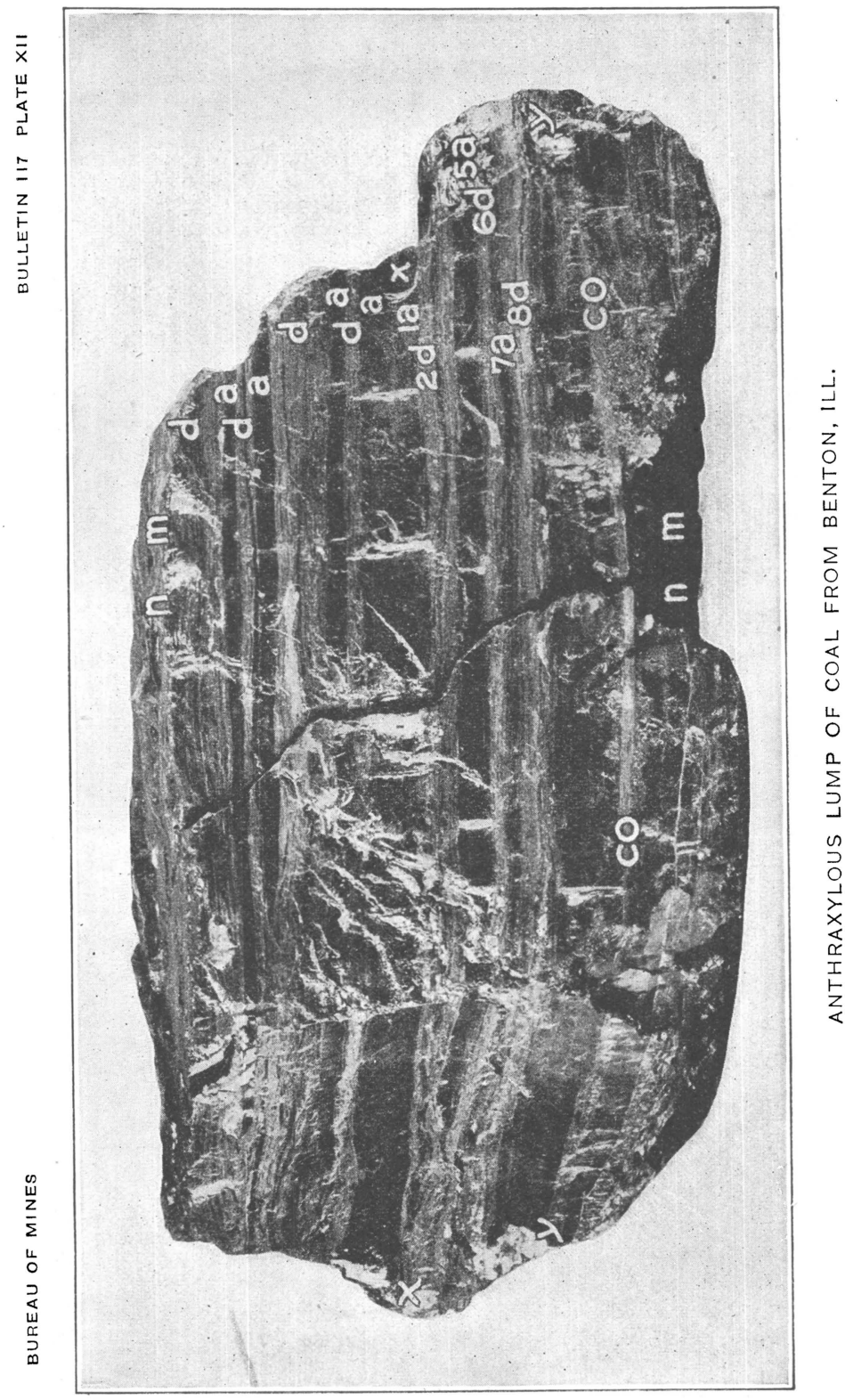

106 


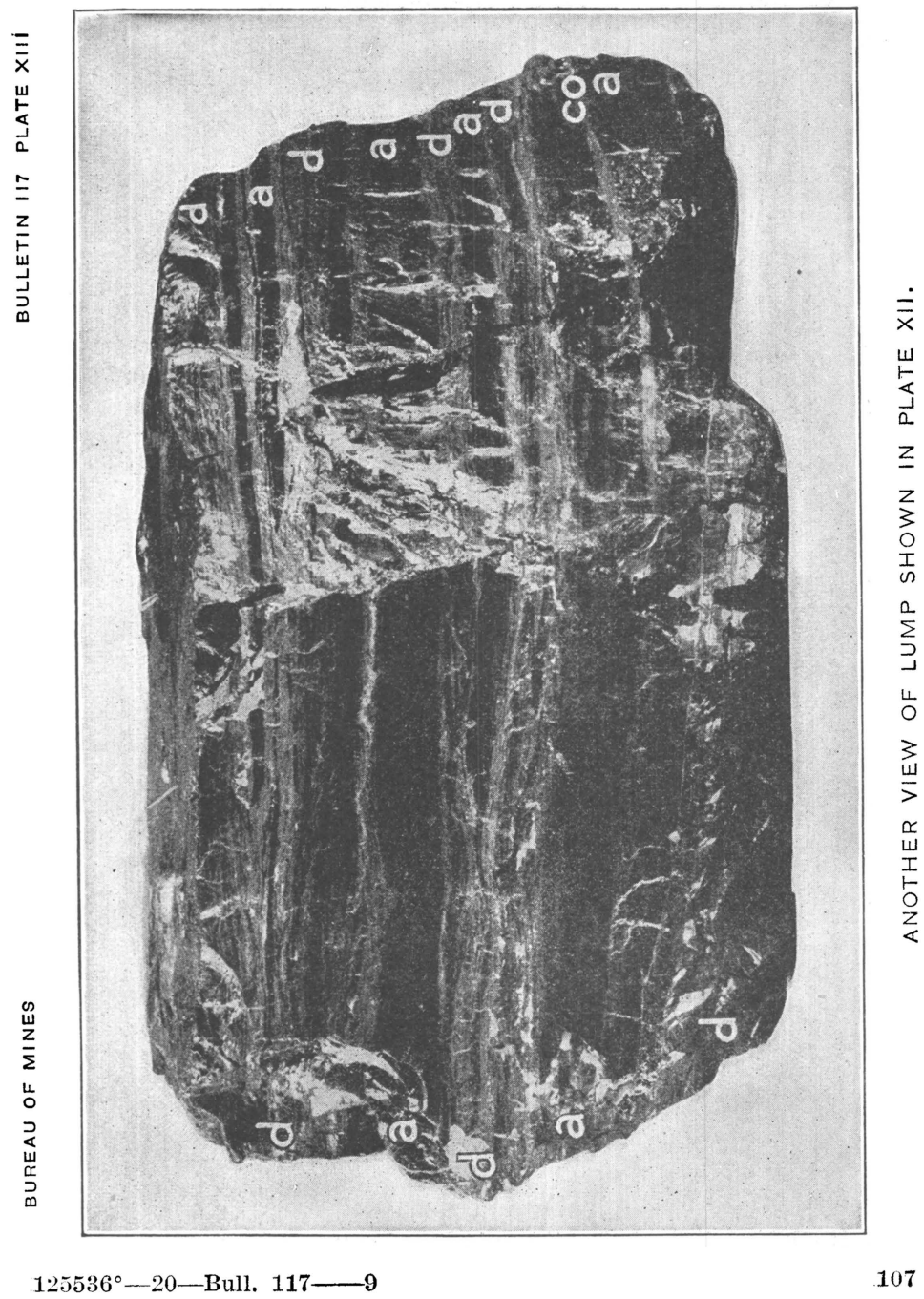




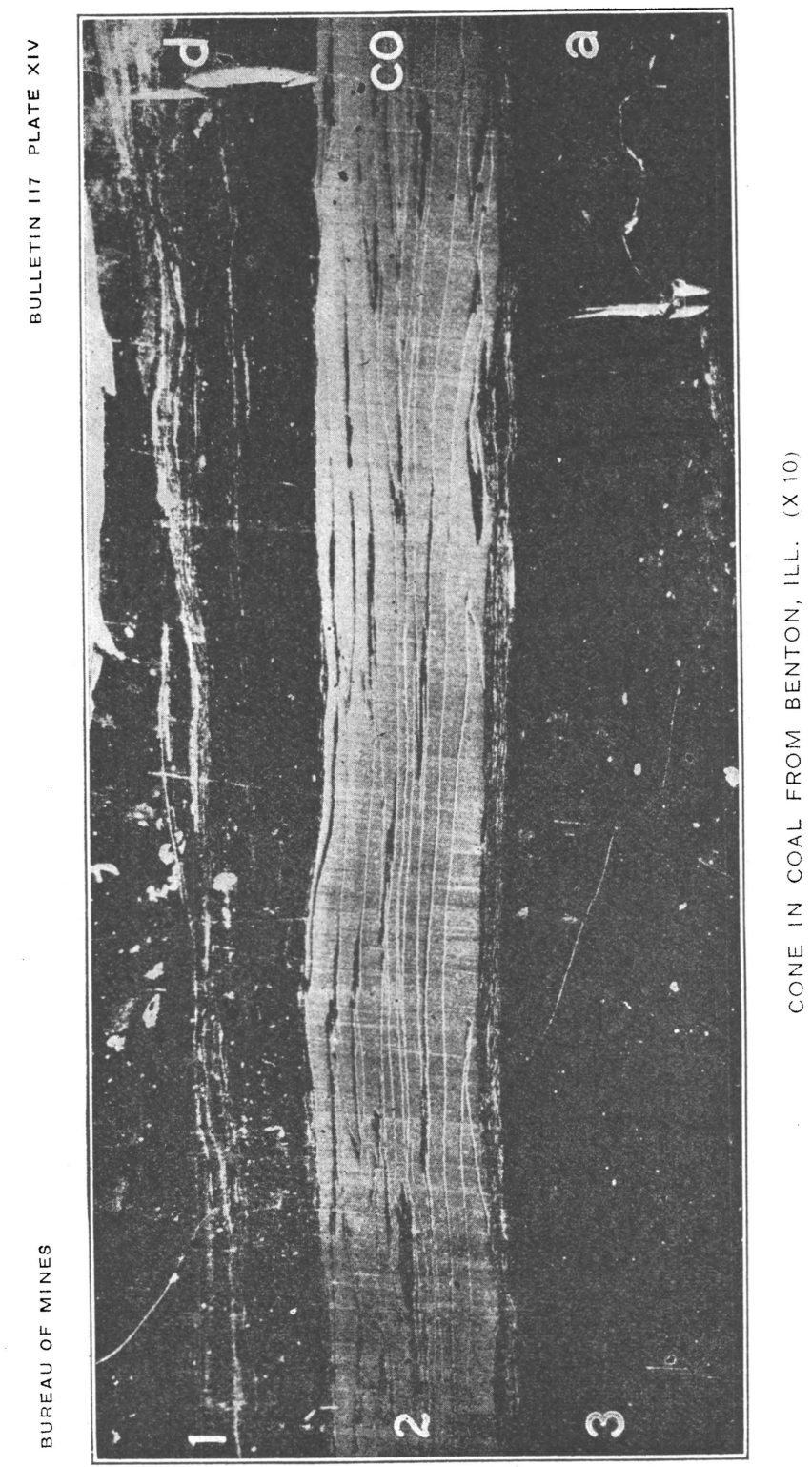




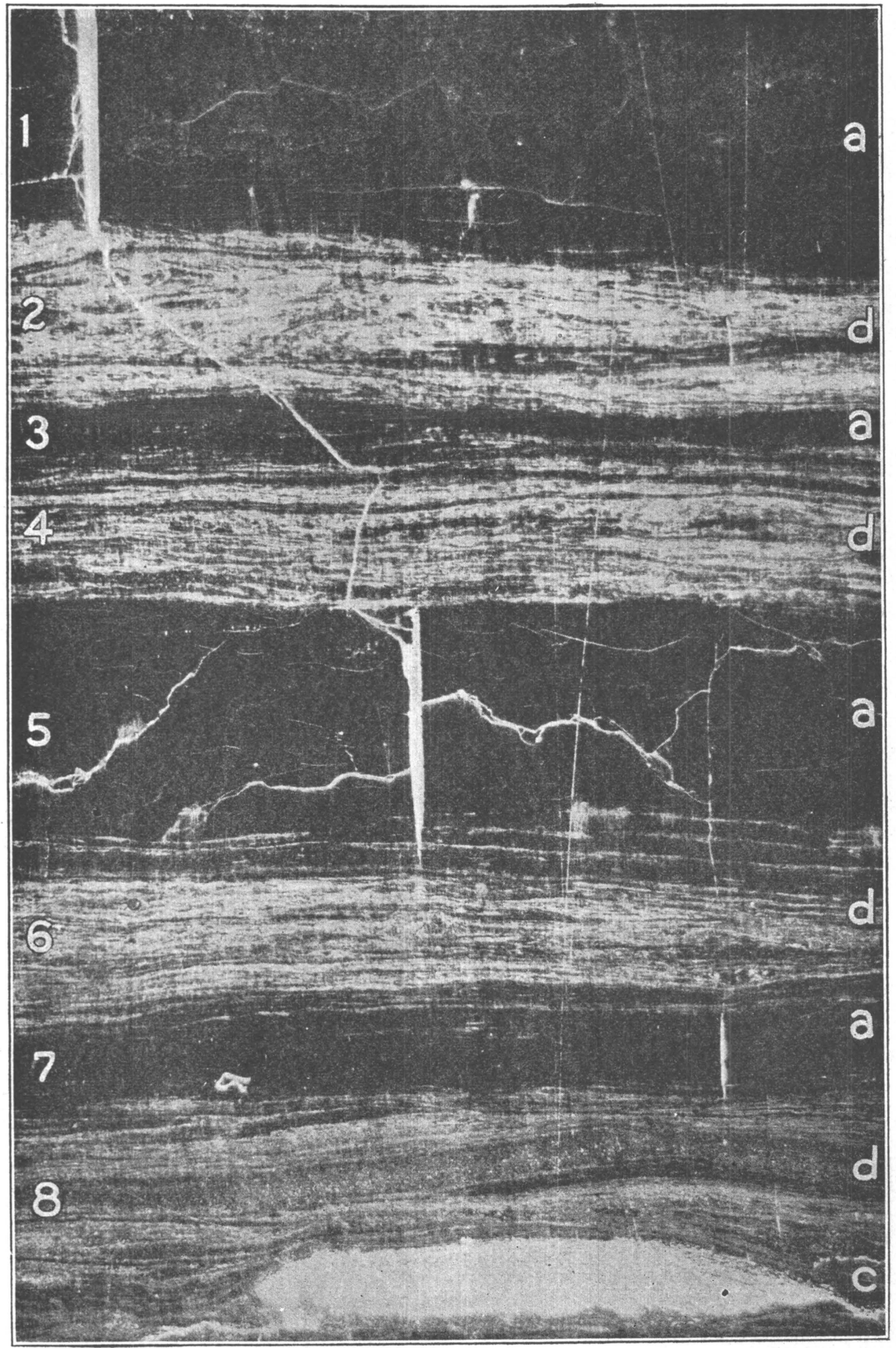

A MAGNIFIED AREA FROM PLATE XII. (X 10) 


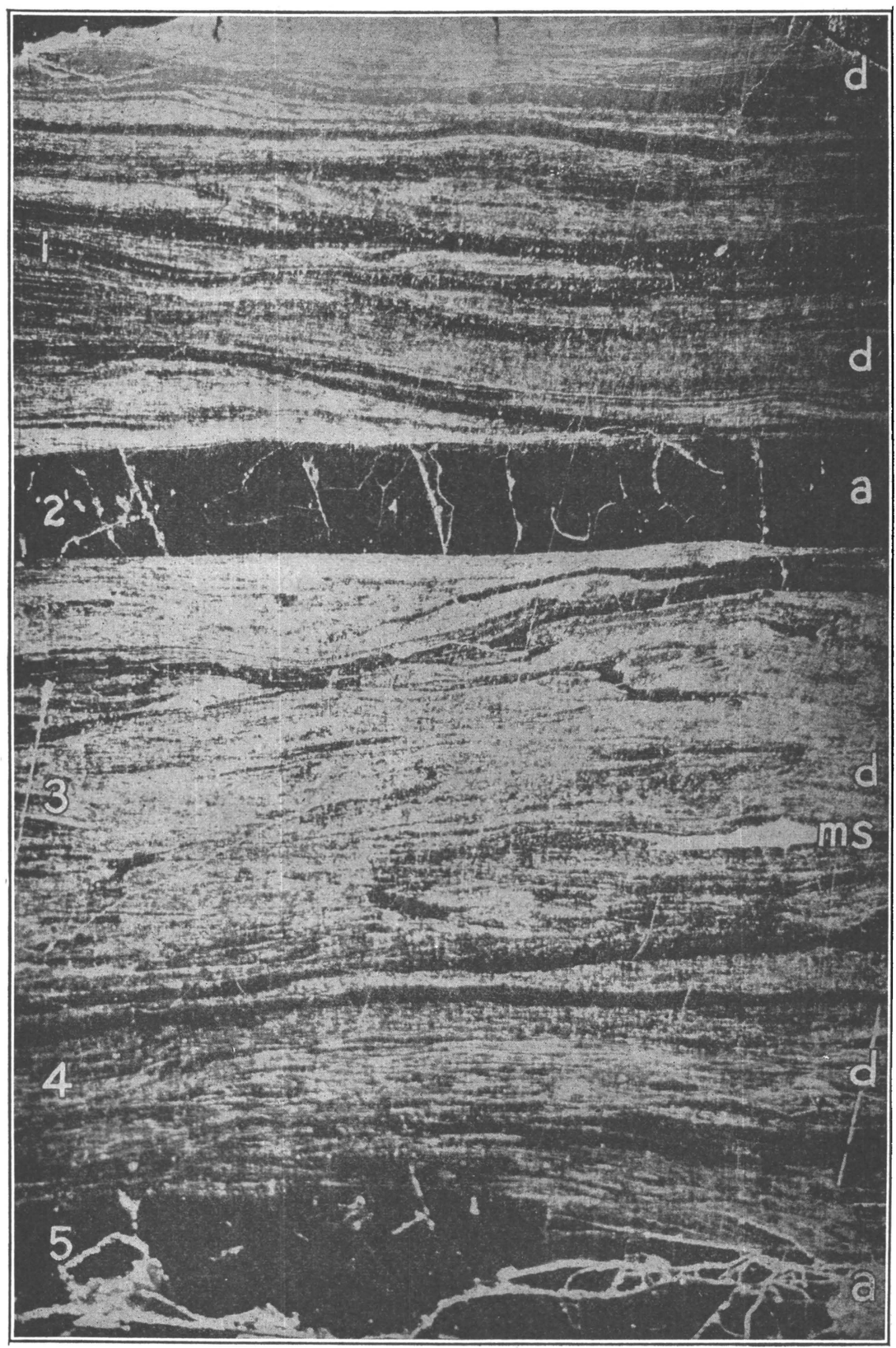

110

A MAGNIFIED AREA FROM PLATE XIII. (X 10) 


\section{PLATE XVII.}

\section{OPAQUE VERTICAL SECTION.}

A continuous area of about $\frac{1}{2}$ by 3 inches of a cross section of a piece of coal from Royalton, Ill. $(\times 10)$, prepared by reflected light from an opaque polished surface perpendicular to the bedding plane, and showing the embedding matrix, the attritus, and further lamination of the "dull coal" into thinner lenticular laminæ of "bright coal" or anthraxylon. 1-a, 3-a, 5-a, and 7-a are "bright coal" or anthraxylon; 2-d, 4-d, and 6-d, "dull coal"; h-h is the remains of a hollow stem.

\section{PLATE XVIII.}

\section{OPAQUE VERTICAL SECTION CONTINUED.}

7-a, 9-a, and 11-a represents "bright coal" or larger anthraxylon components ; 8-d and 10-d, "dull coal"; 10-p, petrified inclusions. $(\times 10$.

\section{PLATE XIX.}

OPAQUE VERTICAL SECTION CONTINUED.

11-a and 14-a, "bright coal"; 12-d and 15-1, "dull coal"; 13-c, charcoal. ( $\times 10$.

\section{PLATE XX.}

\section{OPAQUE VERTICAL SECTION CONTINUED.}

15-d, 17-d, 19-d, 21-d, and 24-d, "dull coal "; 16-a, 18-a, and 20-a, thin strips of " bright coal ;" 22-a, "bright coal," derived from a hollow stem ; 23-d, débris in the hollow part of 22-a. ( $\times 10$. 


\section{PLATE XXI.}

\section{OPAQUE VERTICAL SECTION CONTINUED.}

24-d and 26-d, "dull coal," or dêloris, includingr a thin strị of anthraxylous coal, 25-a. $(\times 10$.

\section{PLATE XXII.}

\section{OPAQUE CROSS SECTIONS.}

A. Opaque polished section of the Royalton coal $(\times 10)$ photographed by means of reflected light to show the lamination of the "dull coal," but mainly to show the cross sections of the so-called rodlets. Horizontal cleavage surfaces of layers similar to the layers seen at $3-\mathrm{r}$ are shown in Plate XXXY, $A$ and $B$.

$B$. Opaque polished vertical section $(\times 10)$, prepared in a similar way, from another horizon of the Royalton coal, representing its general lamination into thin lenticular laminæ of "bright coal," or anthraxylon shown in black embedded in the attritus in gray. Inclusions of charcoal are shown in the iower part

\section{PLATE XXIII.}

\section{OPAQUE CROSS SECTION.}

An opaque polished cross section $(\times 10)$ prepared by means of reflected light, from the coal from Zeigler, Ill., representing mainly a portion of the "dull coal," between the two anthraxylon components $1-i$ and 5 -il. Note the lumping of the attritus and the cross section of rodlets at $2-d$.

\section{PLATE XXIV}

\section{OPAQUE CROSS SEC'TIONS.}

A. An opaque, polished cross section $(\times 10)$ of the coal from Zeigler, Ill., representing thin lamina composed of matter derived from the woody parts of plants alternating with matter derived largely from leaves. The dark strips represent anthraxylon, and the light, delicate striations represent leaf cuticles including an attritus largely derived from leaf tissues. Similar lamine more highly magnified, are shown in Plate XCVIII, $A$ and $B$.

$B$. An opaque. polished cross section from the Sesser coal $(\times 10)$, showing "dull coal" at 1-d and 3-d and anthraxylon at 2-a and 4-a. Plate CI, $\boldsymbol{A}$ $(\times 200)$, Plate CI, $B$, and Plate CII, $A(\times 1,000)$ are prepared from a cross section of the anthraxylon shown at $2-\mathrm{a}$ in this photograph. 


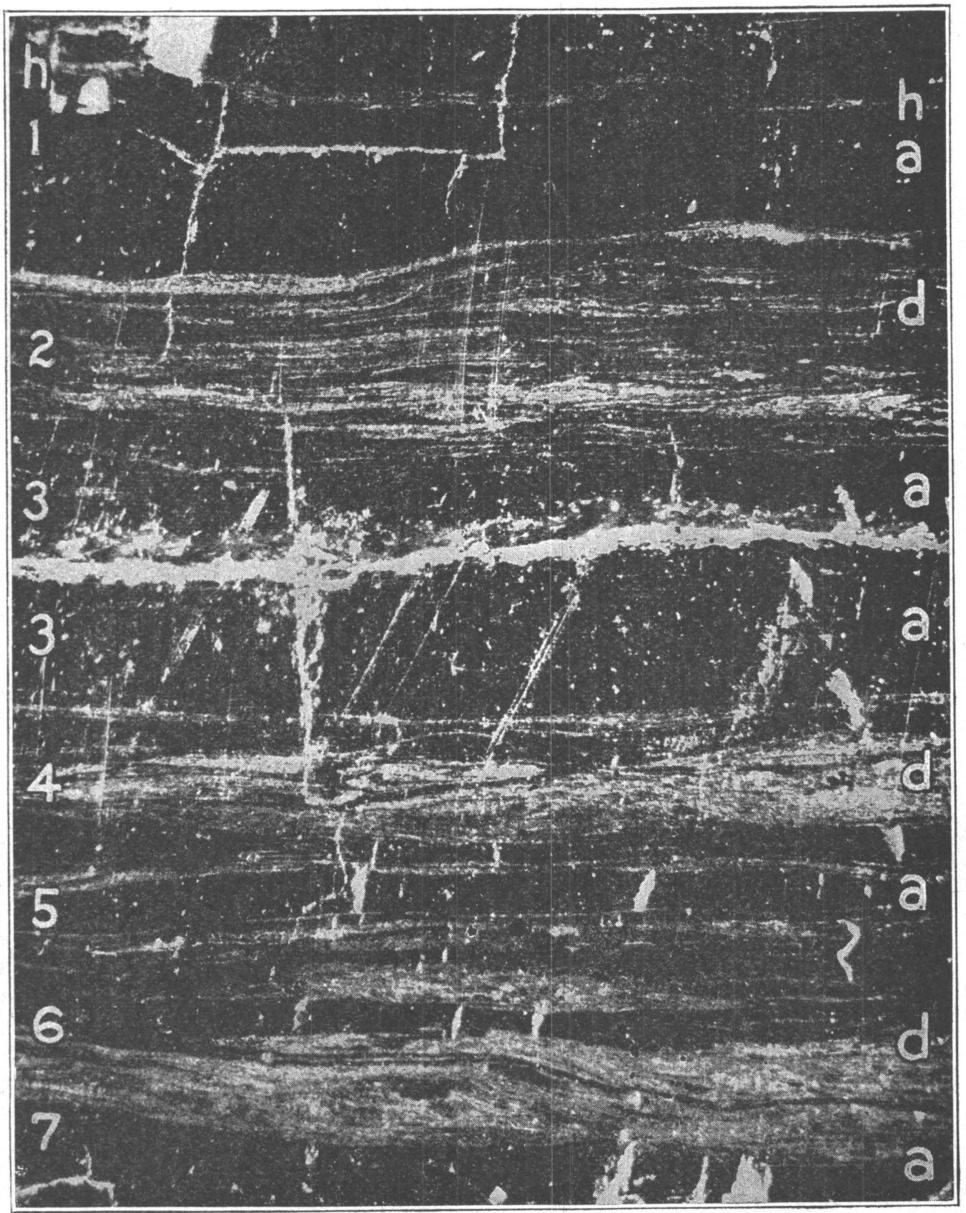

OPAOUE VERTICAL SECTION OF COAL FROM ROYALTON, ILL. (X 10) 


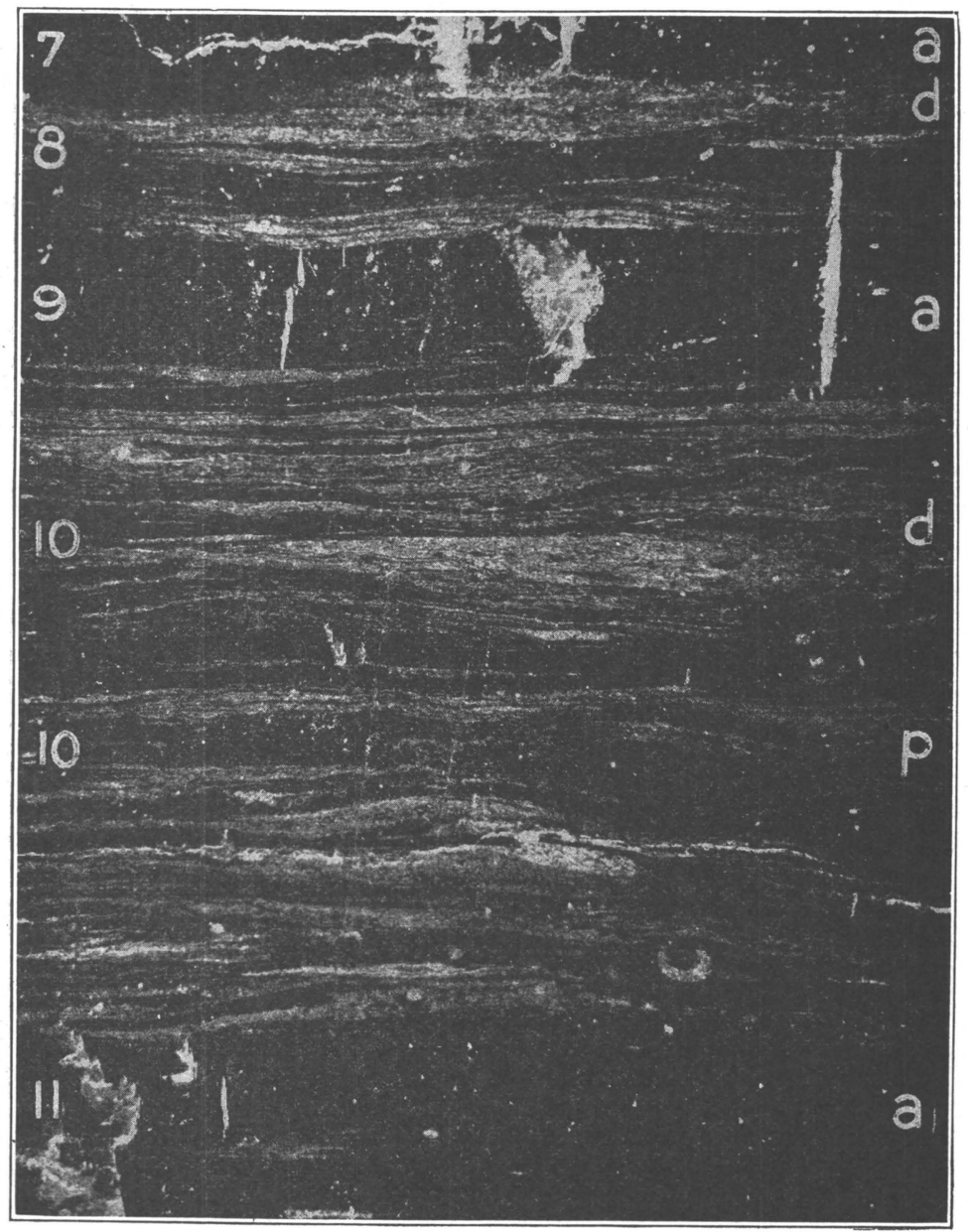




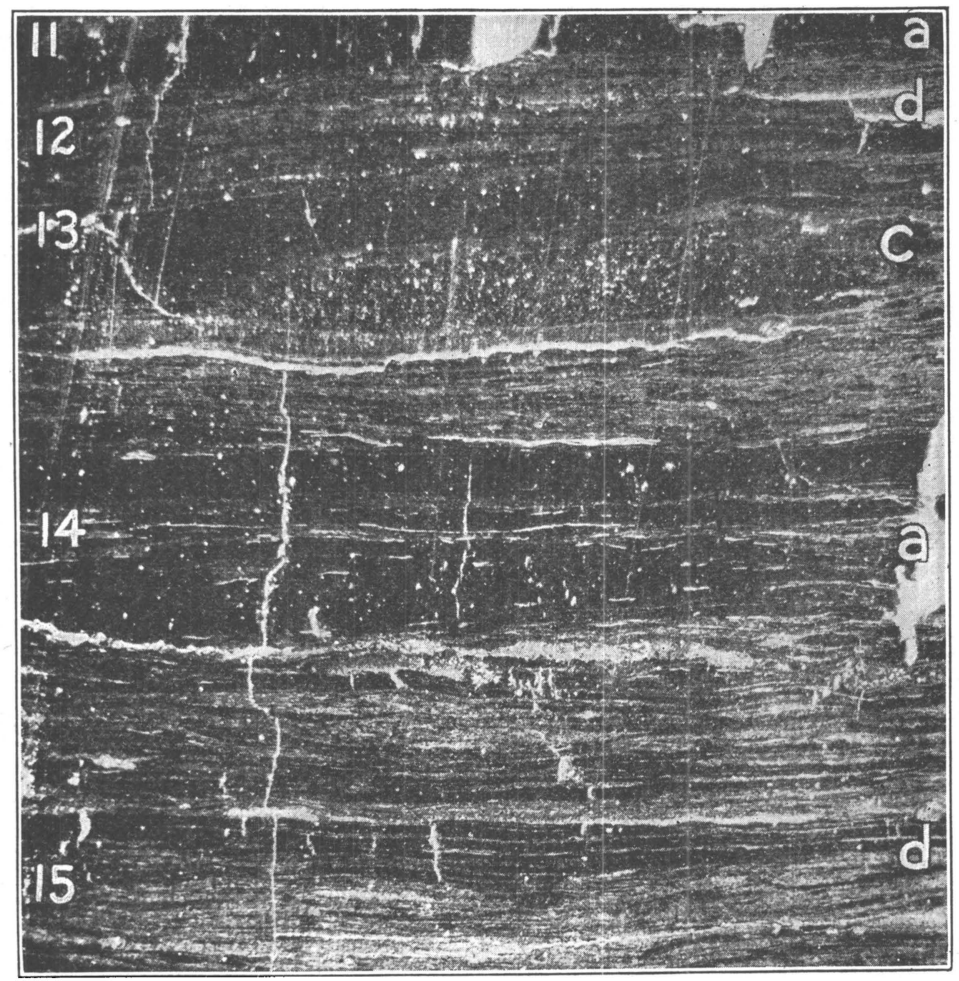

CONTINUATION FROM PLATE XVIII. (X 10) 


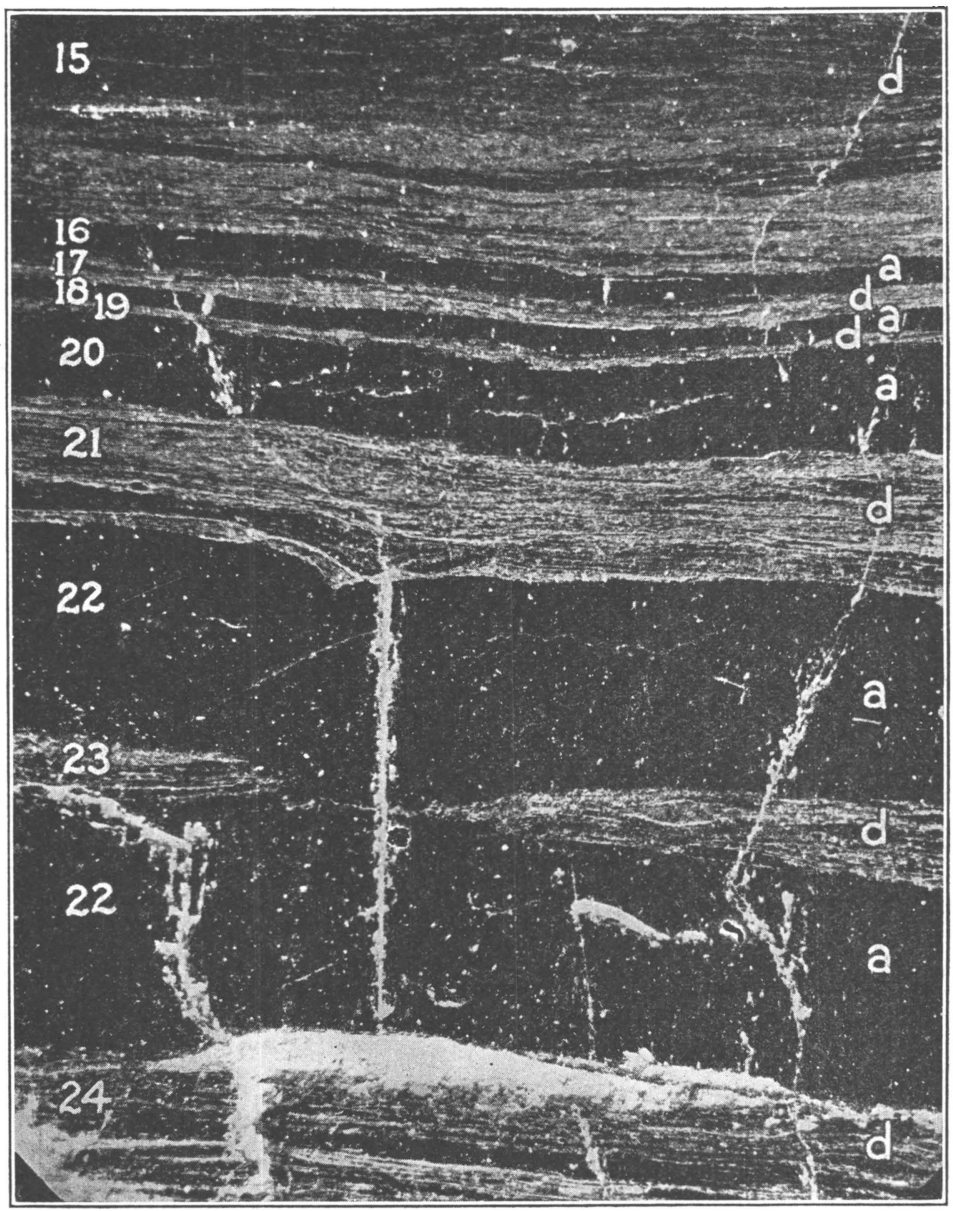

CONTINUATION FROM PLATE XIX. (X 10) 


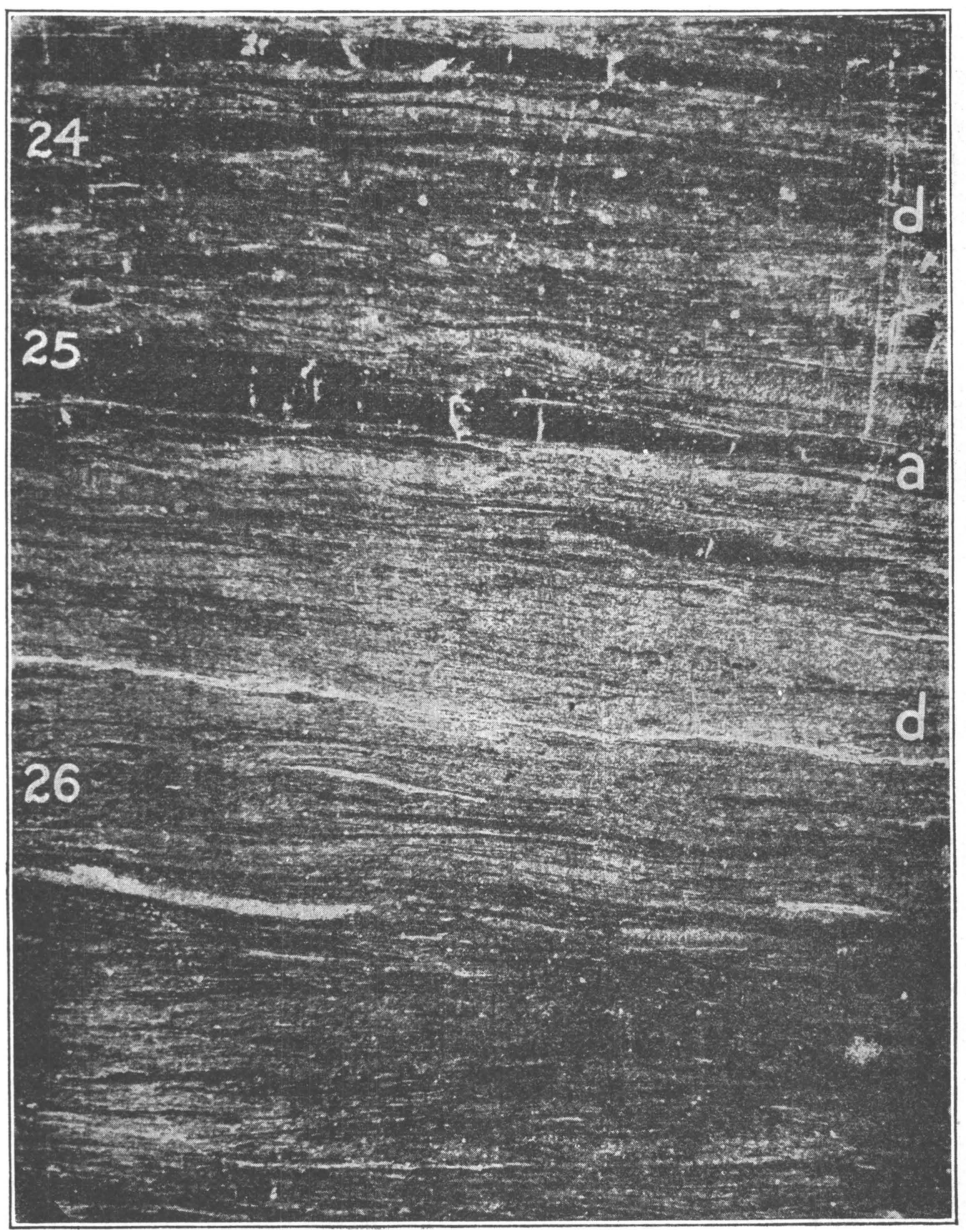

CONTINUATION FROM PLATE XX. (X 10) 


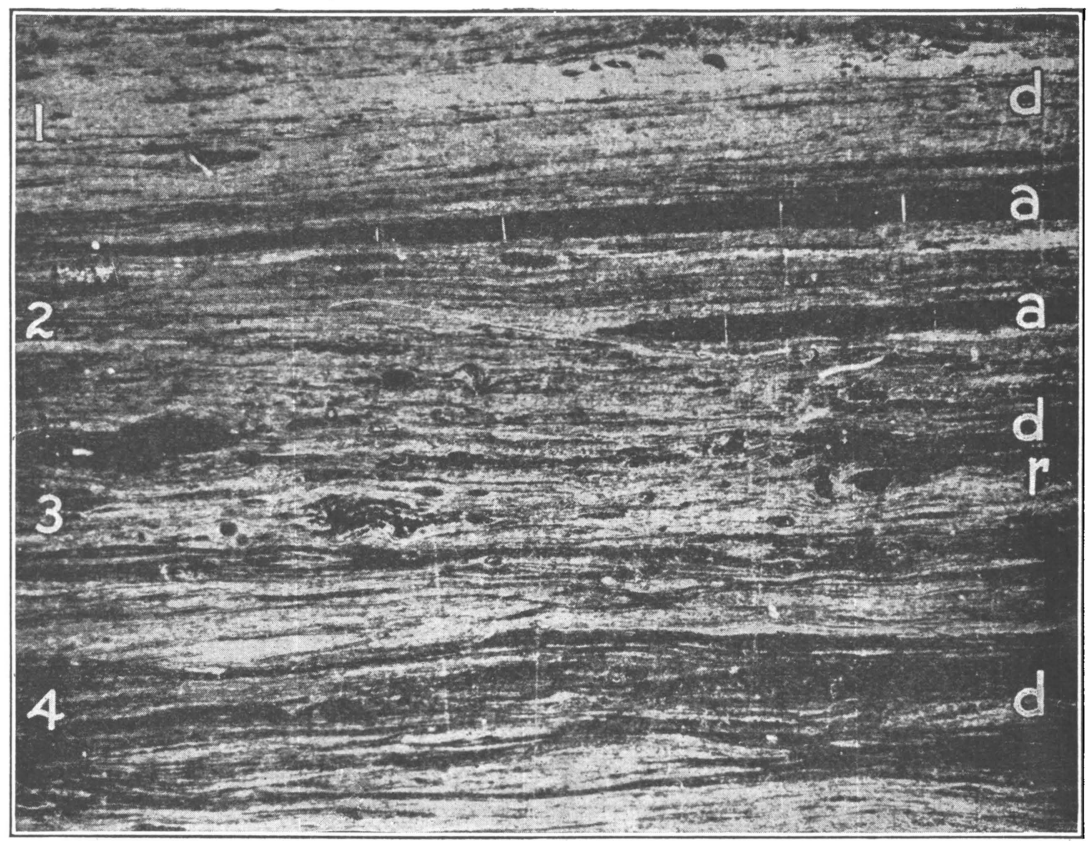

A. CROSS SECTION OF RODLETS IN COAL FROM ROYALTON, ILL. (X 10)

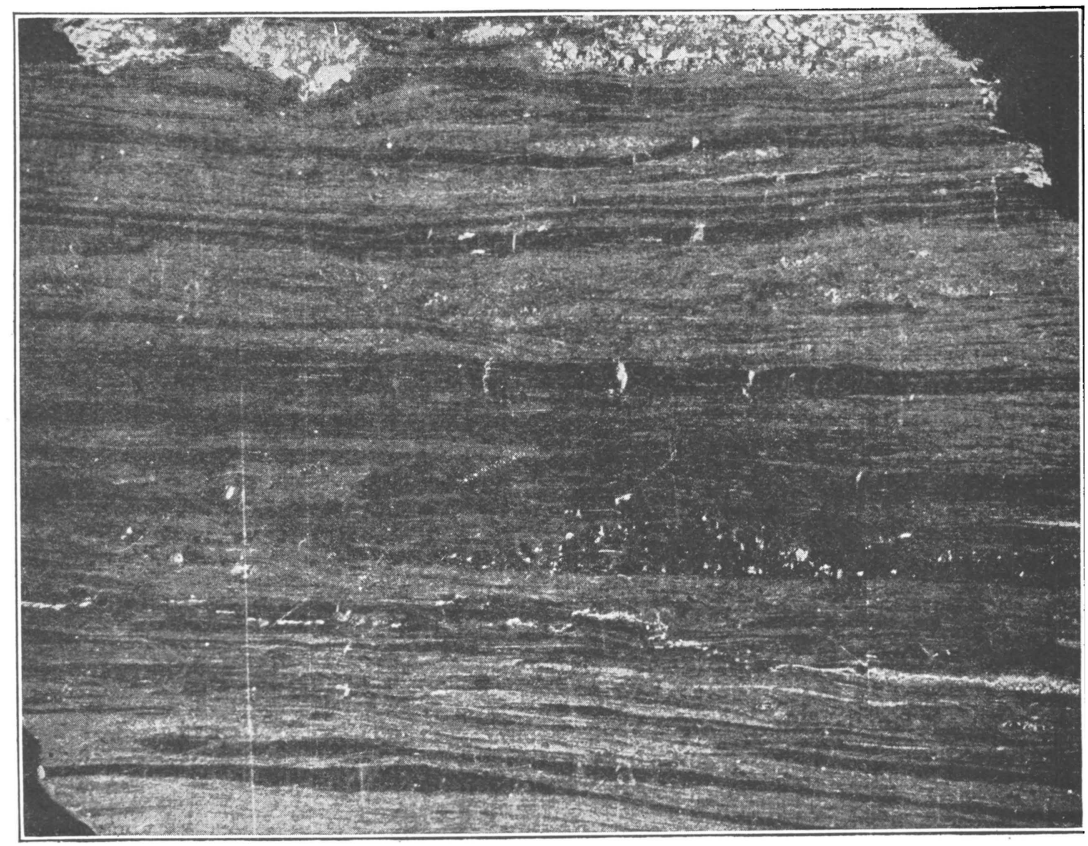

B. LAMINATION IN COAL FROM ROYALTON, ILL. (X 10) 


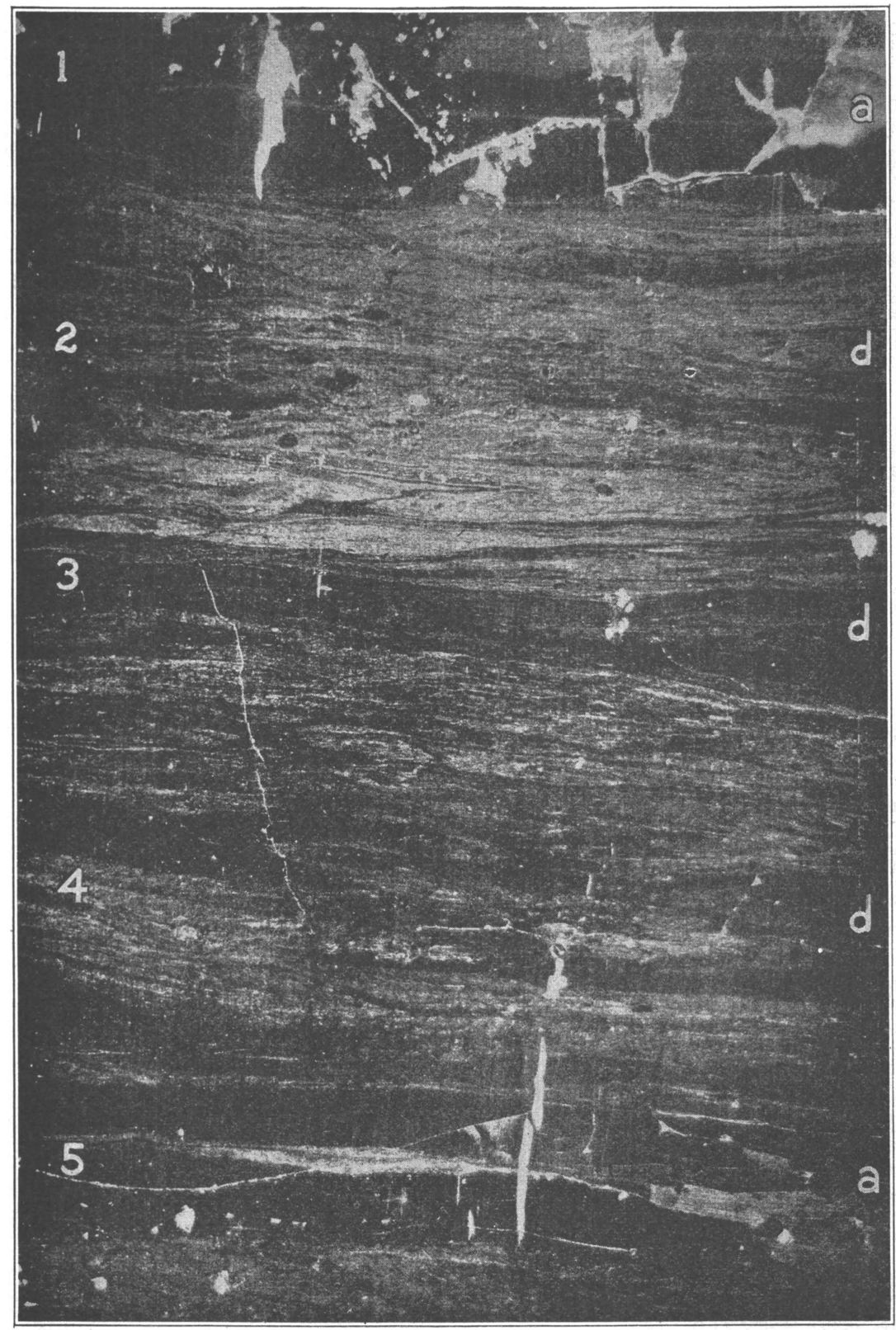

OPAQUE CROSS SECTION OF COAL FROM ZEIGLER, ILL. (X 10) 


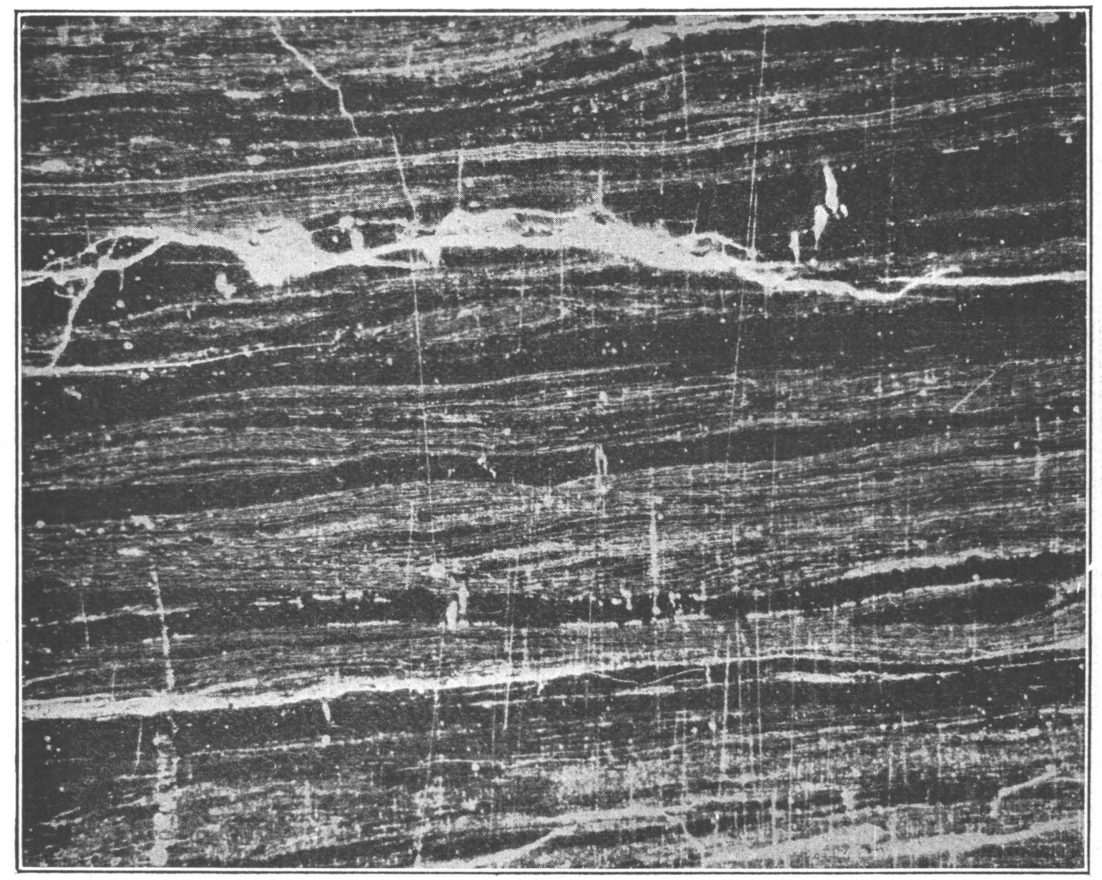

A. OPAQUE CROSS SECTION OF THIN LAMINAE, COAL FROM ZEIGLER, ILL. (X 1G)

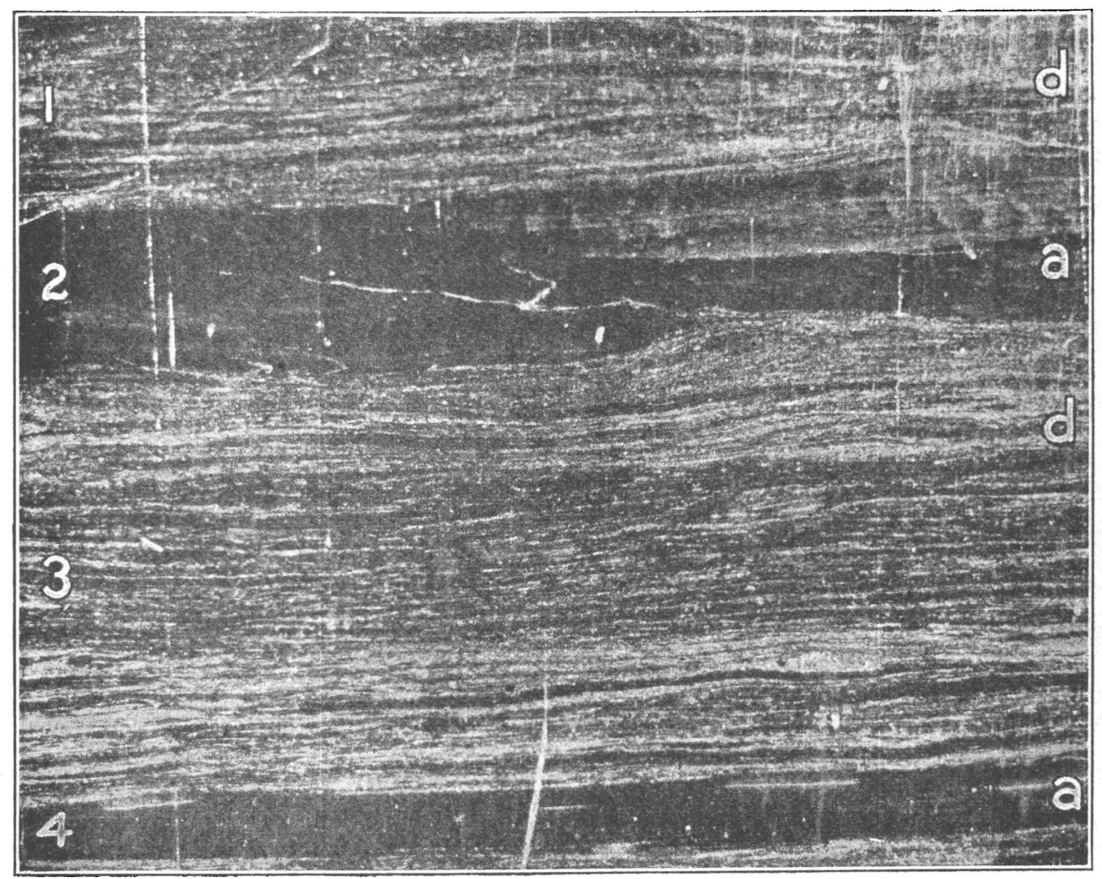

$B$. OPAQUE CROSS SECTION OF COAL FROM SESSER, ILL. (X 10) 


\section{PLATE XXV.}

\section{HORIZONTAL Cleavage SURFACE.}

A horizontal cleavage surface of the coal from the Vandalia mine $(\times 2)$, from the block of coal shown in Plate CXLII, along the level indicated by $x-x$ through a compact part of the coal. On its surface are exposed the anthraxylon components shown as small, thin chips in cross section in Plate CXLIII, A and $B$; here shown as small woody patches. Some of these patches contain fine rodlets.

\section{PLATE XXVI. \\ HORIZONTAL CLEAYAGE SURFACE.}

Another horizontal cleavage surface the Vandalia coal $(\times 2)$, from the block represented in Plate CXIII, from a fracture along the level indicated by $\mathbf{y}-\mathbf{y}$ showing typical structure of the coal, mainly small anthraxylon chips.

\section{PLATE XXVII.}

\section{horizontal Cleavage surFaCe.}

A horizontal clearage surface through the compact coal of the coal from the Benton mine magnified a little more than natural size, showing the woody patches or anthraxylon components on the broad side. Notice that the whole surface shown is covered with patches showing woody structures.

\section{PI.ATE XXVIII.}

\section{HORIZONTAL CLEAVAGE SURFACE.}

$A$. Horizontal cleavage surface along the level $\mathrm{x}-\mathrm{y}-\mathrm{z}$, fracture 1 , of the block of the coal from the Benton mine shown in Plate XI, $A$ and $B$. The sides, $\mathrm{x}-\mathrm{y}$, $y-z$, and $z-x$ correspond to the sides $x-y, y-z$, and $z-x$ of the block shown in Plate XI, $A$ and $B$. On the surface are a number of patches, or anthraxylon components, showing woody structure, and many fine "needles" or " rodlets," embedded in the attritus.

$B$. Another horizontal clearage surface along the level $\mathrm{t}-\mathrm{u}-\mathrm{v}$, fracture 2 . in the block of coal represented in Plate XI, $A$ and $B$. The sides $\mathrm{t}-\mathrm{u}, \mathrm{u}-\mathrm{v}$, and $\mathrm{v}-\mathrm{t}$ correspond to the sides $\mathrm{t}-\mathrm{u}, \mathrm{u}-\mathrm{v}$, and $\mathrm{v}-\mathrm{t}$ of the sides of the block represented in Plate XI, $A$ and $B$. This surface shows a larger total structureless area in which a number of woody patches, or anthraxylon chips, are located. At the corner " $u$ " the fracture splits through a thicker anthraxylon chip. 


\section{PLATE XXIX.}

\section{HoRIzONTAL ClEAVAge SURFACE.}

Two horizontal cleavage planes from the Hart-Williams coal. The upper surface shows a number of anthraxylon chips, some containing " needles." The lower surface is largely through the interior of an anthraxylon chip, but also shows several patches with woody structures.

\section{PLATE XXX.}

\section{HORIzontal Cleavage sURFACE.}

A horizontal cleavage surface through compact coal of the Sesser coal of the block shown in Plate $\mathrm{X}$, along the horizon indicated by $\mathrm{x}-\mathrm{y}$, magnified a little more than natural size, and showing structures similar to the HartWilliams coal. Some of the woody patches contain "needles." The irregular dark areas represent fractures through the interior of the anthraxylon chips.

\section{PLATE XXXI.}

\section{HORIZONTAL CLEAVAGE SURFACE.}

A horizontal cleavage surface of the Buxton coal $(\times 5)$, showing the general structure and appearance.

\section{PLATE XXXII.}

\section{HORIZONTAL Cleavage SURFACE.}

Part of another horizontal cleavage surface of the Buxton coal $(\times 10)$, showing the woody fibers, cuticles, and "needles." 


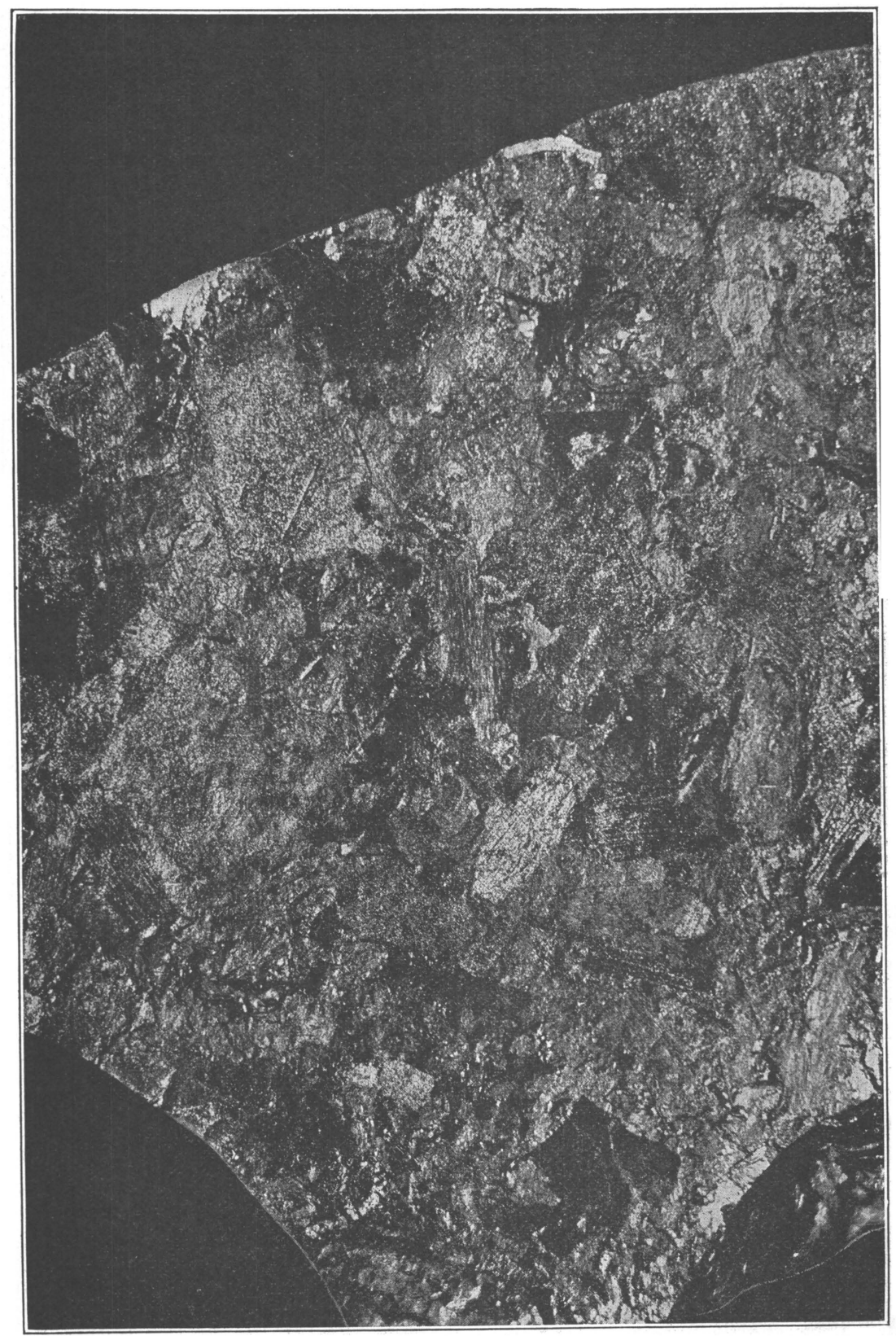

HORIZONTAL CLEAVAGE SURFACE OF COAL FROM THE VANDALIA MINE, NEAR TERRE HAUTE, IND. (X 2) 


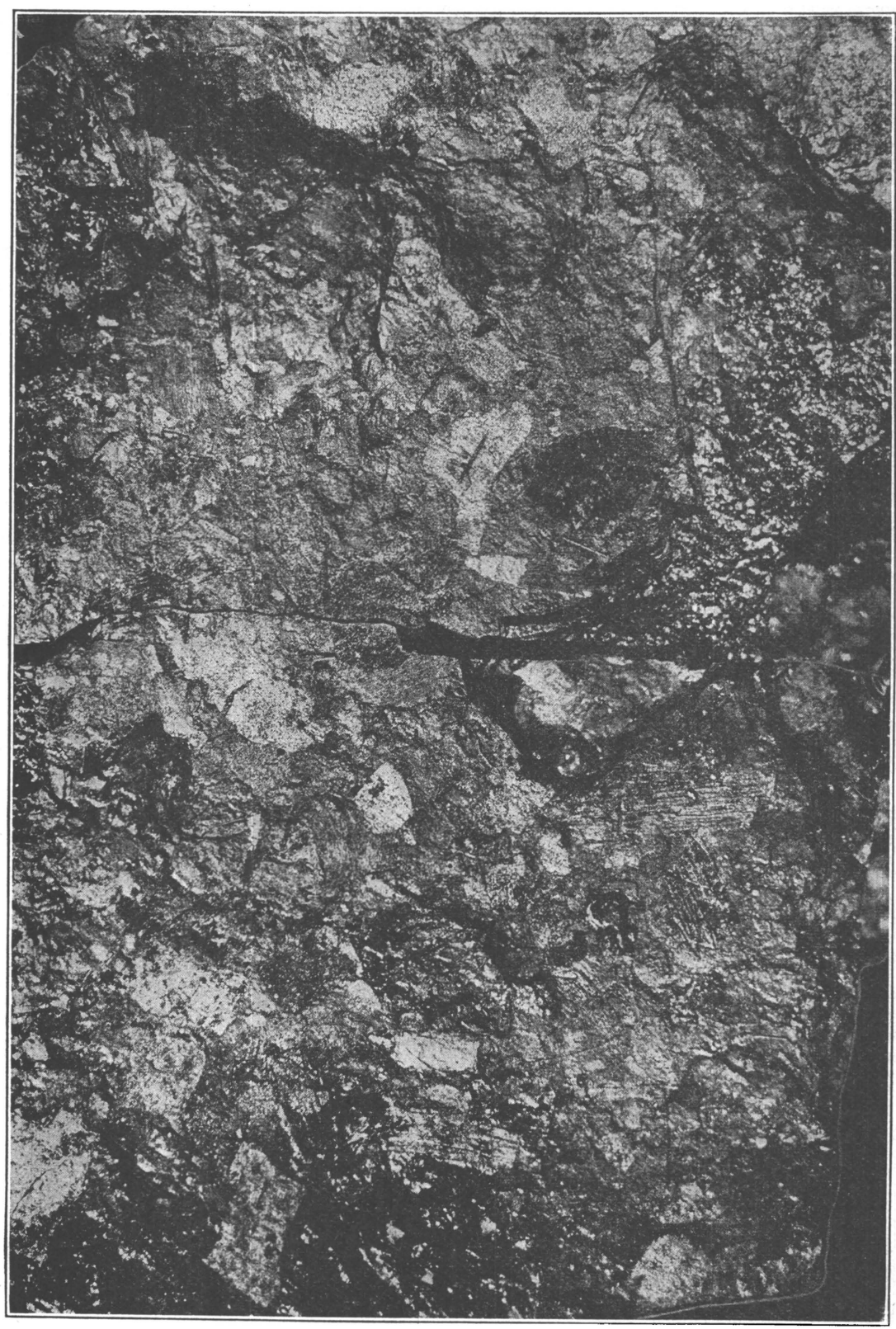

ANOTHER HORIZONTAL CLEAVAGE SURFACE OF COAL FROM THE VANDALIA 


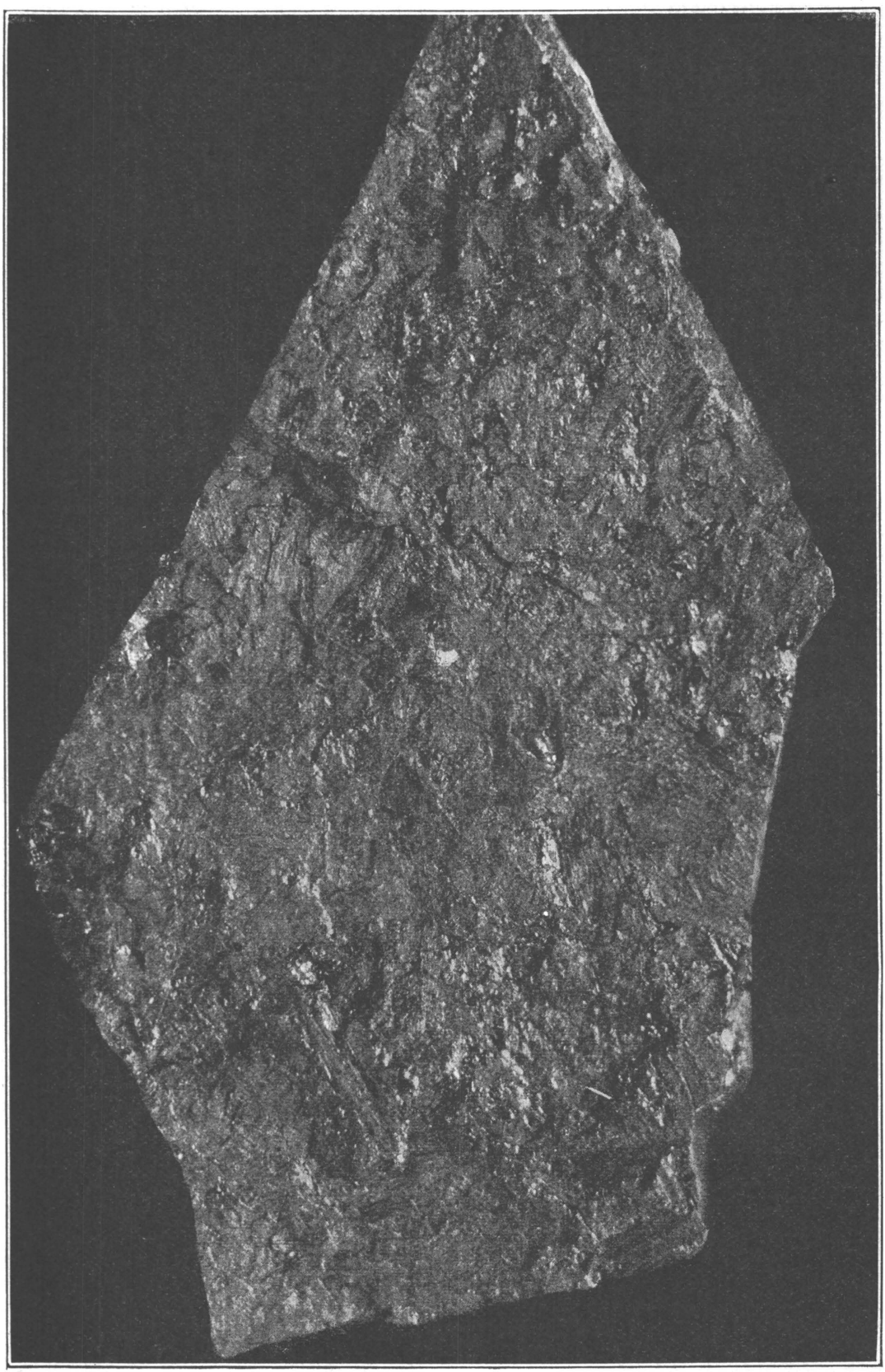

HORIZONTAL CLEAVAGE SURFACE OF COAL FROM BENTON, ILL. 


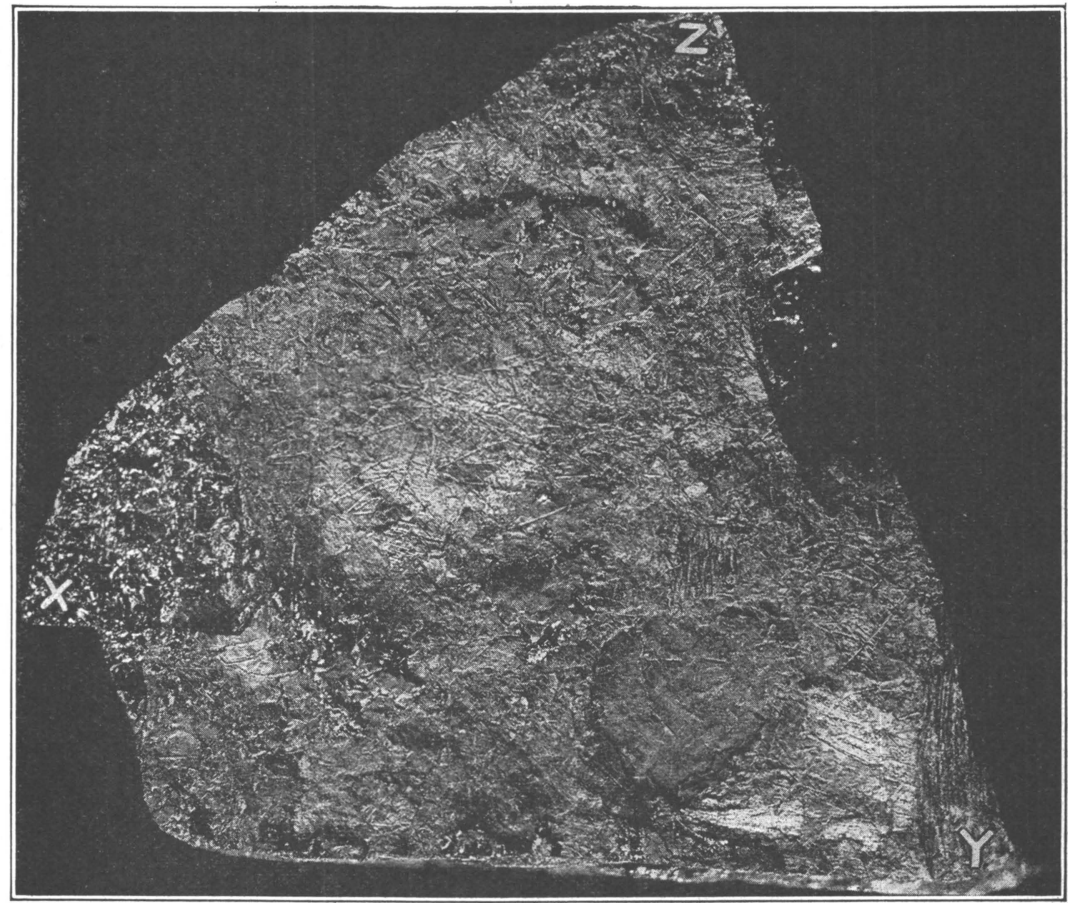

A. HORIZONTAL CLEAVAGE SURFACE OF COAL FROM BENTON, ILL., FROM LUMP SHOWN IN PLATE XI.

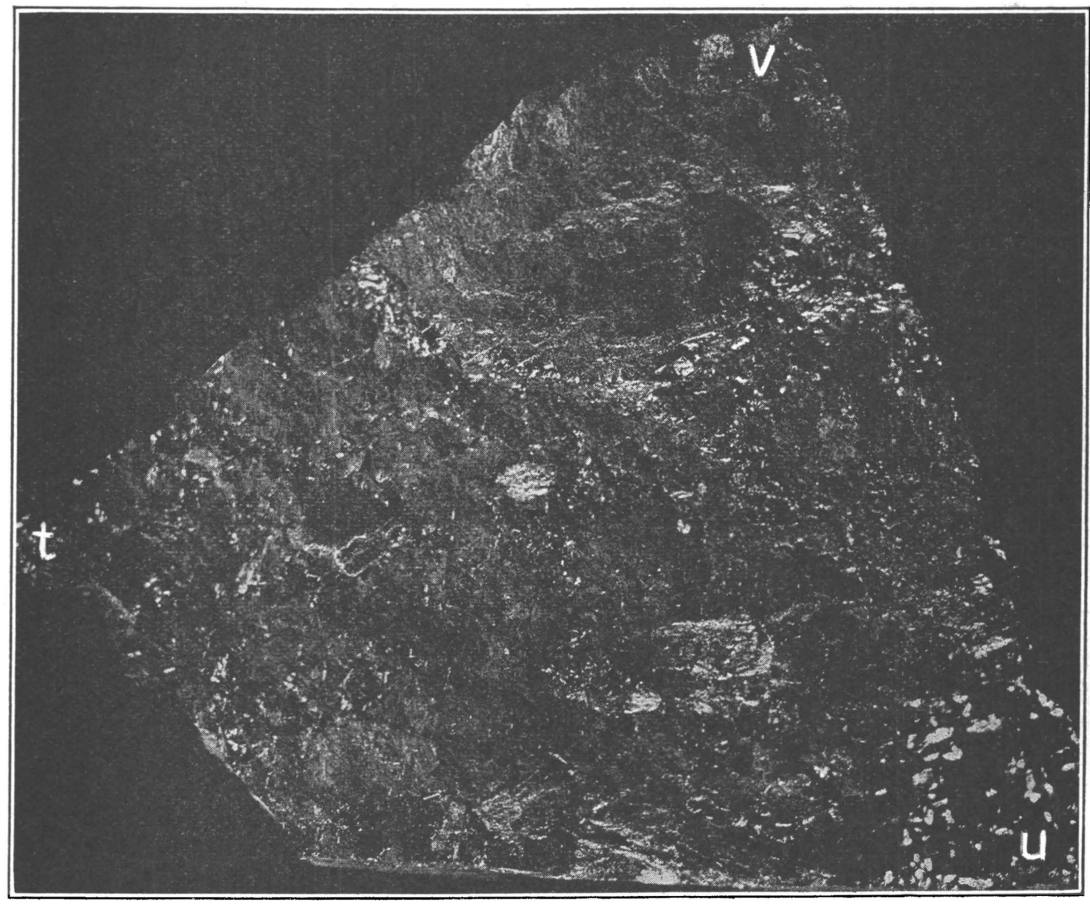

B. ANOTHER CLEAVAGE SURFACE OF LUMP OF COAL SHOWN IN PLATE XI. 126 


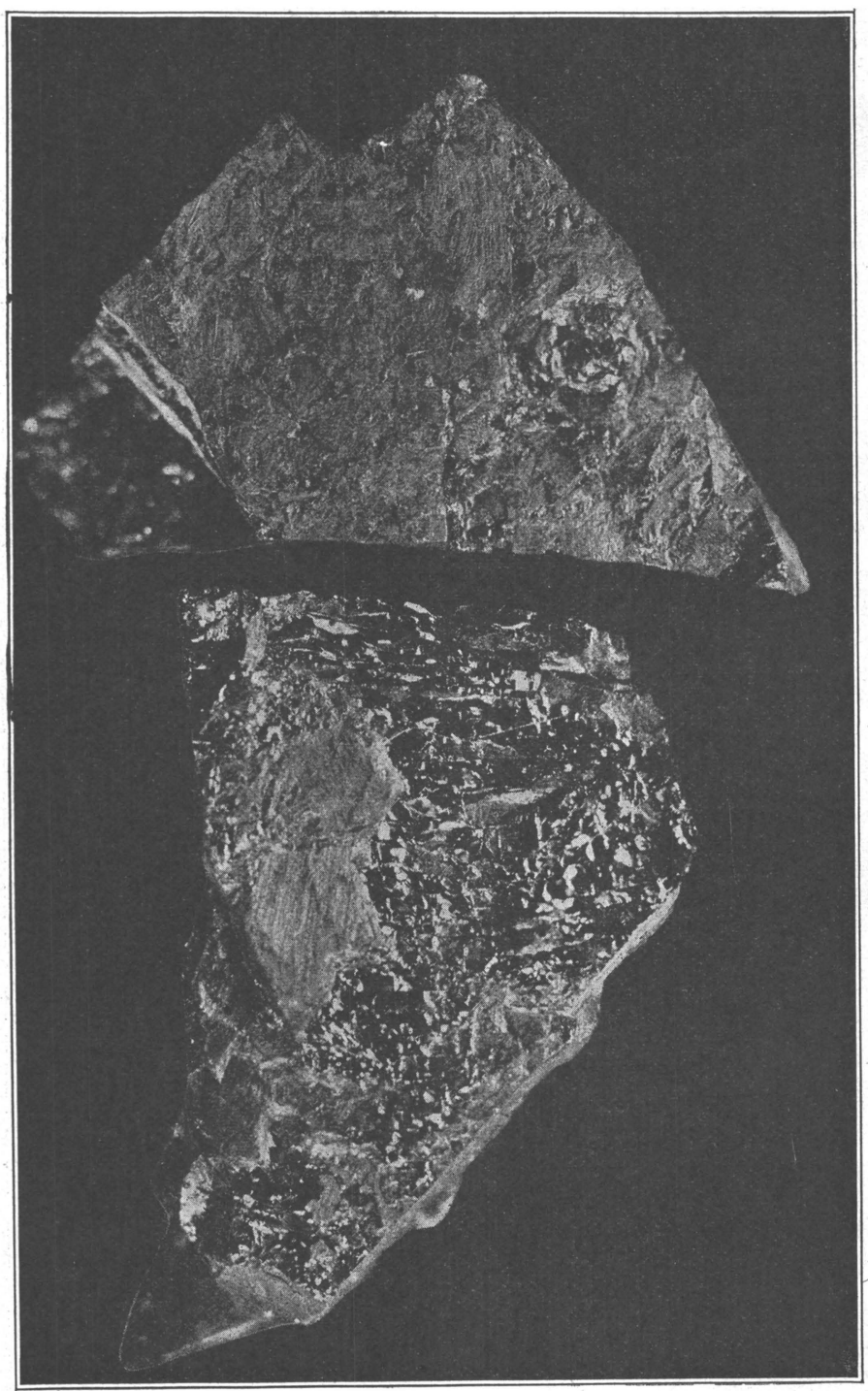

HORIZONTAL CLEAVAGE SURFACES OF COAL FROM THE HARTWILLIAMS MINE. 


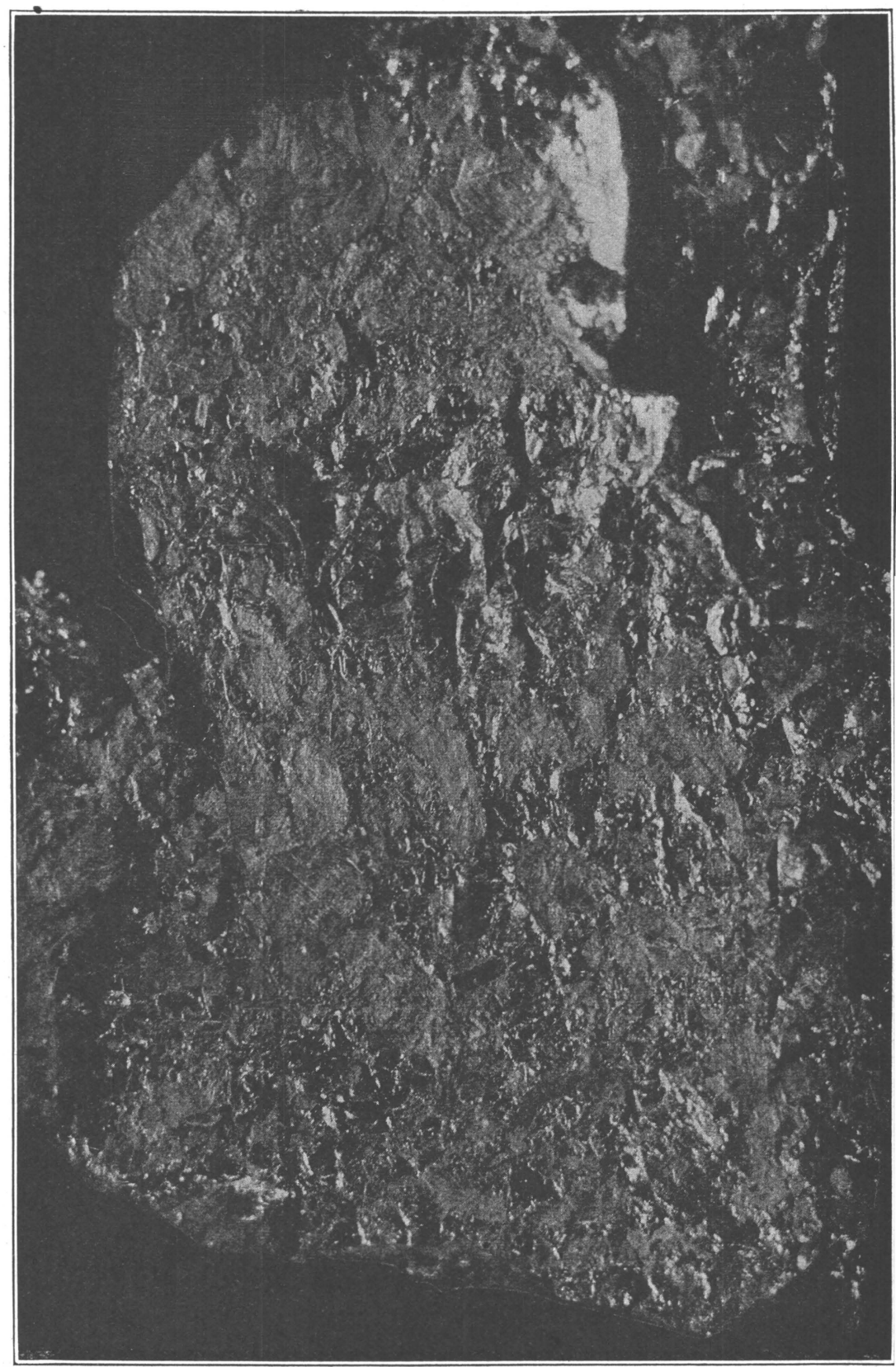

HORIZONTAL CLEAVAGE SURFACE OF COALFROM SESSER, ILL. 128 


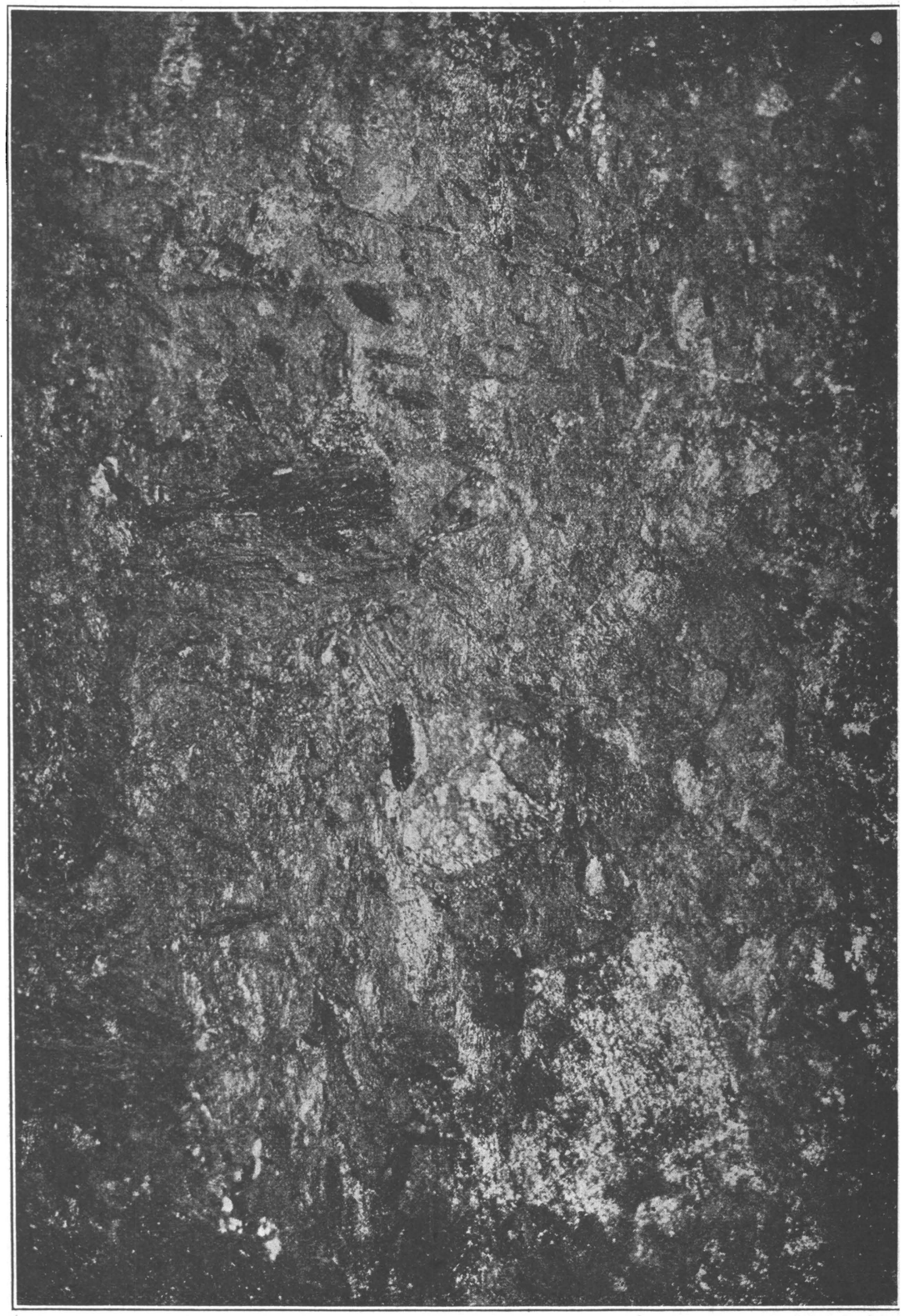

HORIZONTAL CLEAVAGE SURFACE OF COAL FROM BUXTON, IOWA, SHOWS GENERAL STRUCTURE AND APPEARANCE. (X 5) 


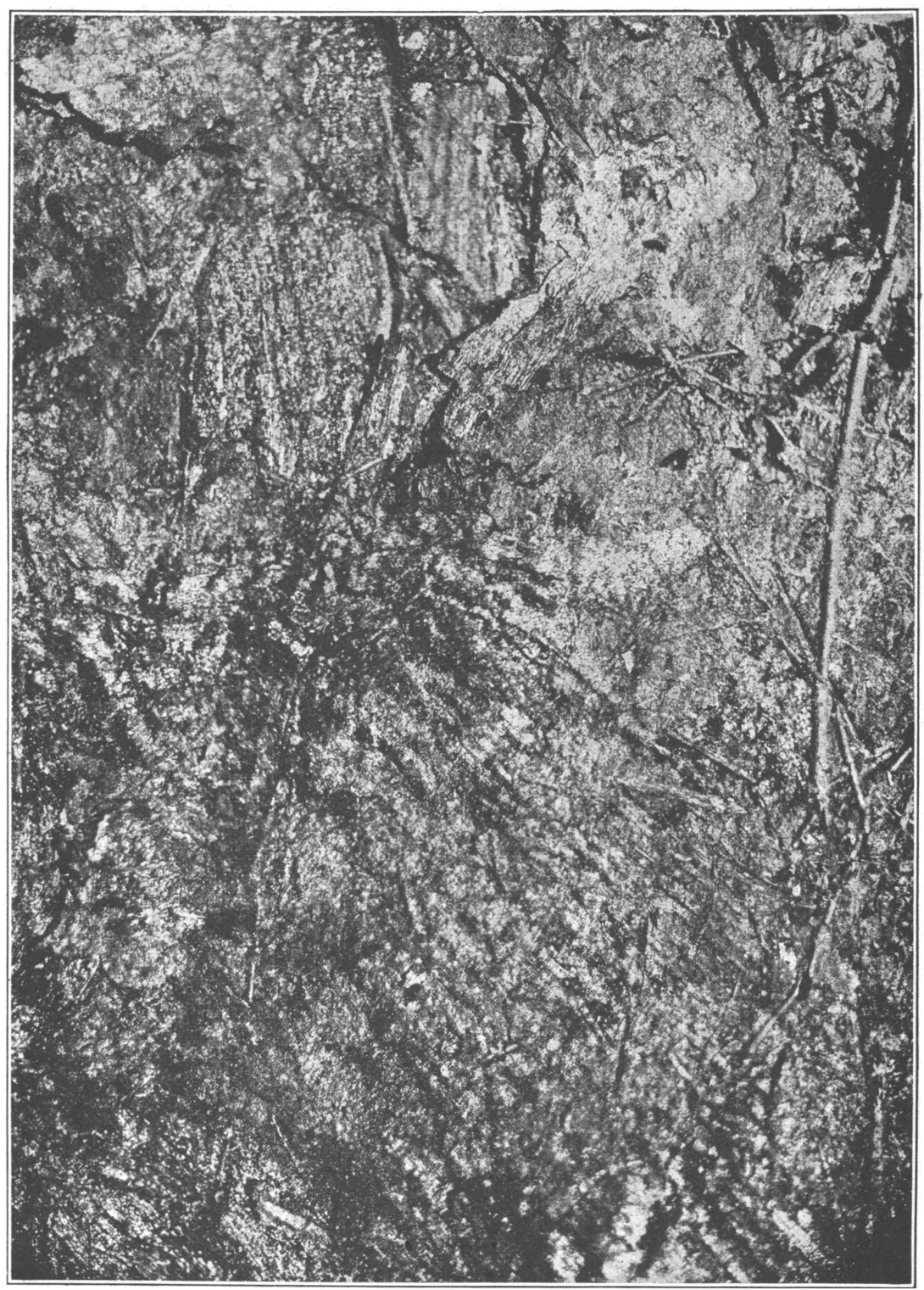

HORIZONTAL CLEAVAGE SURFACE OF COAL FROM BUXTON, IOWA, SHOWS WOODY COMPONENTS. (X 10) 


\section{PLATE XXXIII.}

\section{HORIZONTAL CLEAVAGE SURFACE.}

A horizontal cleavage surface of the Buxton coal $(\times 10)$, containing a large amount of fragmentary cuticles and some woody patches.

\section{PLATE XXXIV.}

\section{HORIZONTAL CLEAVAGE SURFACE.}

A. An oblique section, slightly enlarged, through the compact coal of the Zeigler coal. The irregular black areas and heavy lines represent the fracture through anthraxylon chips; the grayish areas represent largely the attritus.

$B$. A horizontal cleavage fracture $(\times 10)$ through compact coal of the Royalton coal, showing an area with only a few woody patches and a number of "rodlets" or "needles" or their impressions.

\section{PLATE XXXV.}

\section{HORIZONTAL CLEAVAGE SURFACE.}

$A$ and $B$. Horizontal cleavage surfaces $(\times 10)$ through layers of the Royalton coal similar to the layer shown at $3-\mathrm{r}$, Plate XXII, $A$, showing a number of rodlets, bits of coalified woody tissues, parts of stems, petioles, cuticles, and attritus. Similar fractures are found in many coals.

\section{PLATE XXXVI.}

\section{COAL FROM THE PITTSBURGH BED.}

A. Entire vertical cut of an outcrop, very much reduced, of the Pittsburgh bed, between Hobart and Beacon Streets, west of Whitman Street in Pittsburgh, Pa., showing the general layering of the coal as seen in the seam, which is 11 to 12 feet thick here. The lighter layer toward the top of the seam, at 1-1), represents the clay parting persistently found throughout the seam.

$B$. A piece of coal, natural size, from the Iittsburgh seam showing the macroscopic appearance, the lamination, and the structure of the Pittsburgh coal. 1-d, $3-d$ and 5-d represent the so-called "dull coal," 2-a represents a layer of the "bright coal", or anthraxylon; at 4-a is a much thinner strip of "bright coal." The "dull coal" is also composed of thin dull and bright layers alternating with each other. The "bright laminæ," black laminæ in the photograph, are shaped like thin lenses and are embedded in the attritus. 


\section{PLATE XXXVII.}

OPAQUE VERTICAL SECTION OF THE PITTSBURGH COAL FROM THE OAK MIN .

An opaque cross section of Pittsburgh coal from the first foot of coal below the roof at the Oak mine. $(\times 10$. $)$ The gray matter represents the attritus, and the delicate black strips thin anthraxylon chips. Note that some layers are composed of pure attritus. Note also the exines at 4-1, and the carbonaceous inclusion at 5-l. Observe the general distribution of the constituents, the general structure of the thin sheets, and the proportion of attritus to anthraxylon.

\section{PLATE XXXVIII.}

\section{CONTINUED FROM PLATE XXXVII.}

An opaque cross section of the dull coal the second foot from the roof in the Pittsburgh bed at the Oak mine. $(\times 10$. $)$ The coal contains more matter derived from chips of wood, or anthraxylon matter, than that shown in Plate XXXVII.

\section{PLATF XXXIX.}

\section{CONTINUED FROM PLATE XXXVIII.}

An opaque cross section of the third foot of coal below the roof in the Pittsburgh seam, at the Oak mine $(\times 10)$, showing the general structure. Notice that there is a larger proportion of anthraxylon matter in the third foot than in the second (Pl. XXXVII) or the first foot of coal (Pl. XXXVIII). Megaspore exines are shown in the region $2-d$ to $3-d$.

\section{PLATE XL.}

\section{CONTINUED FROM PL.ATE XXXIX.}

An opaque cross section of the fourth foot of coal from the roof in the Pittsburgh seam at the Oak mine. $(\times 10$.$) The anthraxylon is here more dis-$ integrated. Note the megaspore-exines, in light gray, particularly, in the region $3-1$ to $4-d$. At $5-d$ is an inclusion of "mother coal" or carbonaceous matter showing cell structure, many of the cells being filled with quartz. 


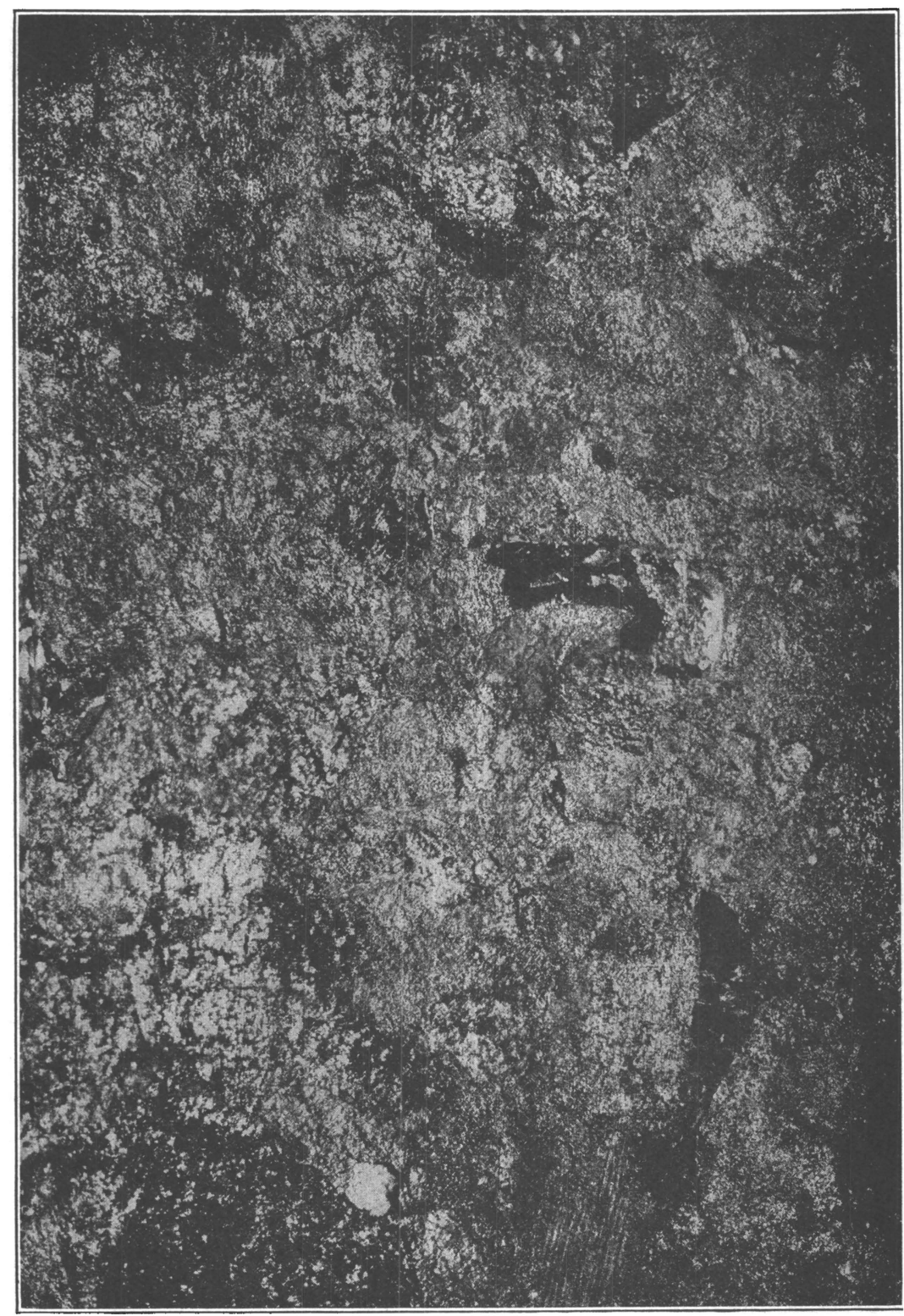

HORIZONTAL CLEAVAGE SURFACE OF COAL FROM BUXTON, IOWA, SHOWS FINELY DIVIDED WOODY MATTER. (X 10) 


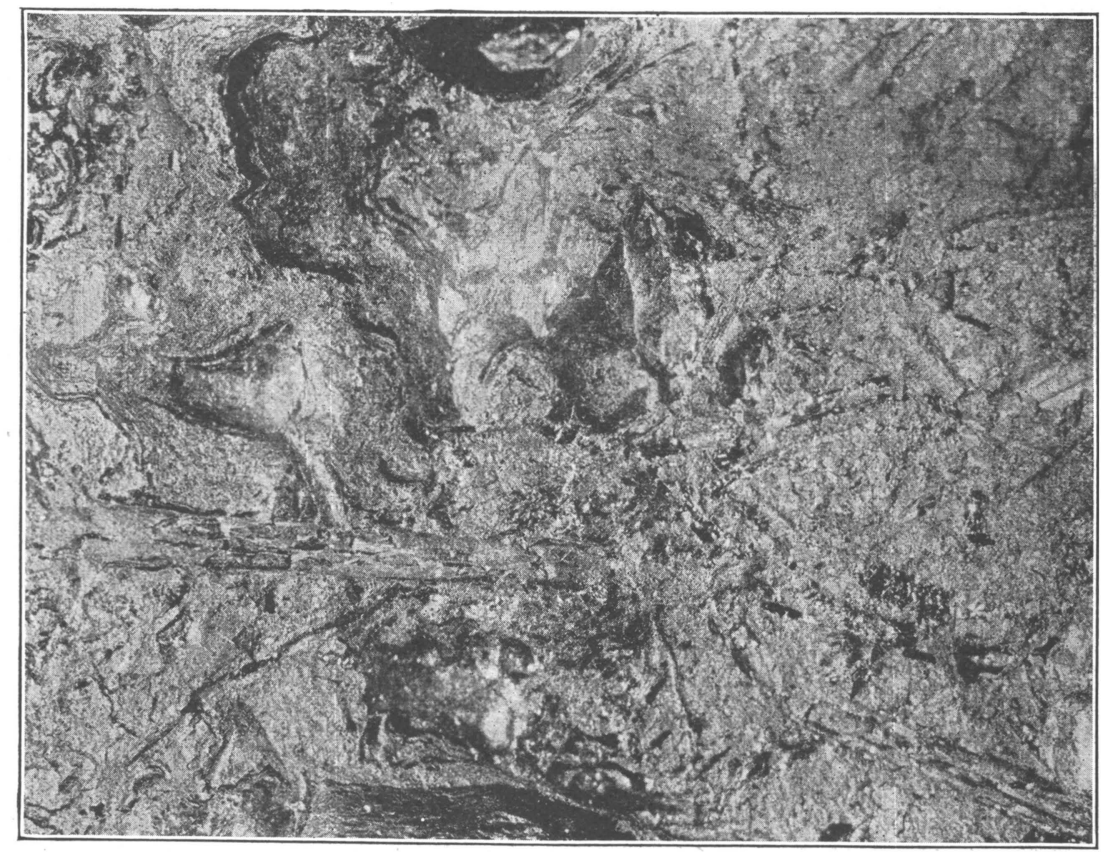

A. horizontal cleavage surface of coal from zeigler, ill.

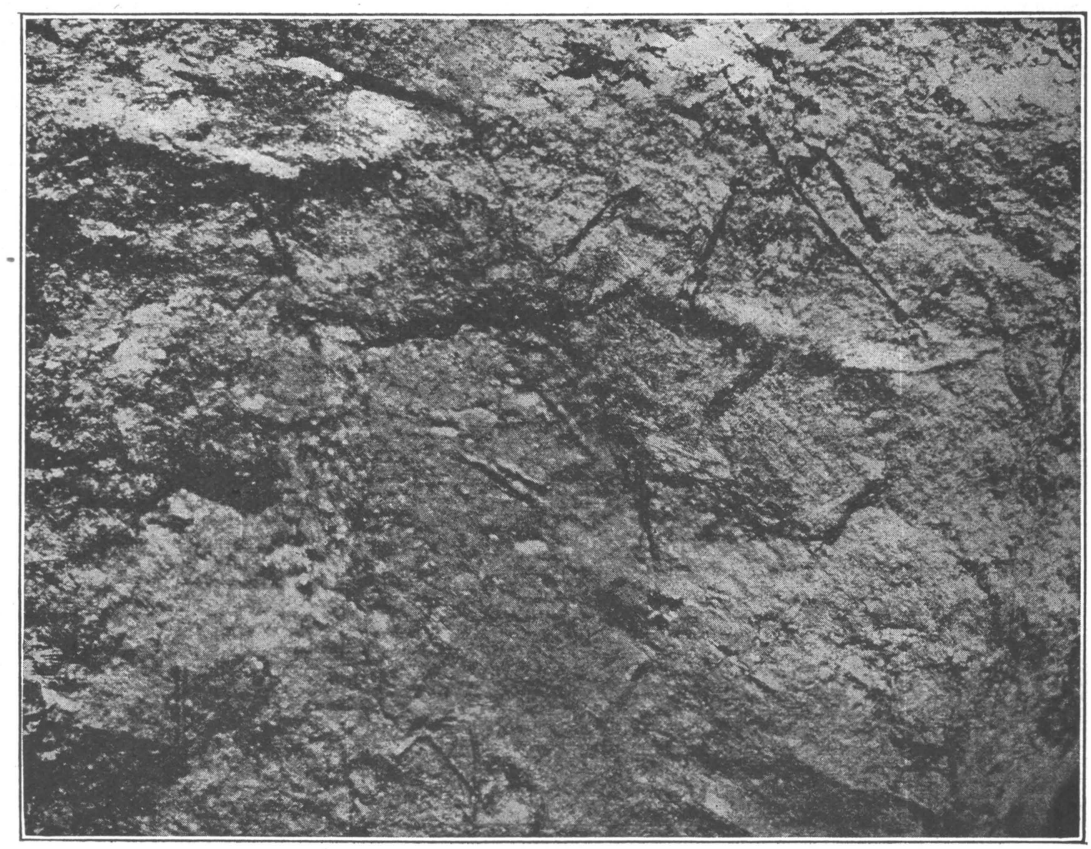

B. HORIZONTAL CLEAVAGE SURFACE THROUGH "COMPACT" COAL OF THE COAL

FROM ROYALTON, ILL. (X 10) 


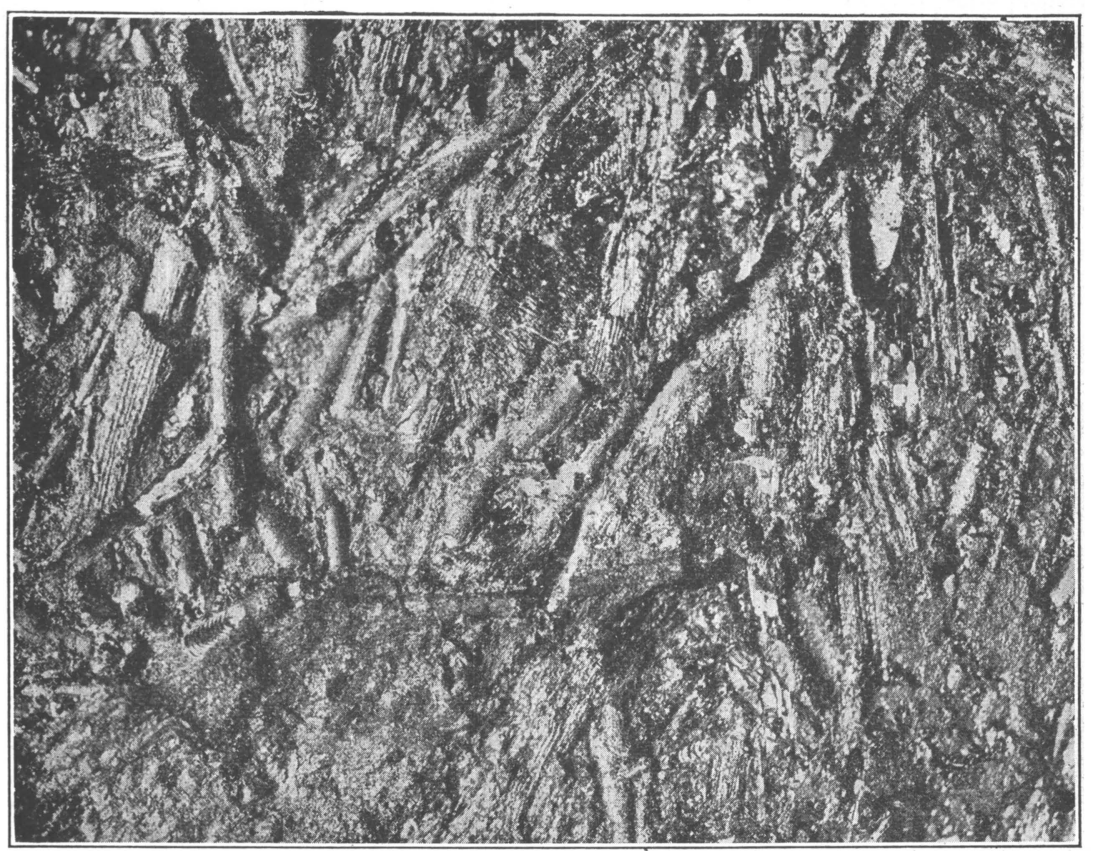

A. horizontal cleavage surface of the coAl from royalton, ill., SHOWING RODLETS AND WOODY TISSUES. (X 10)

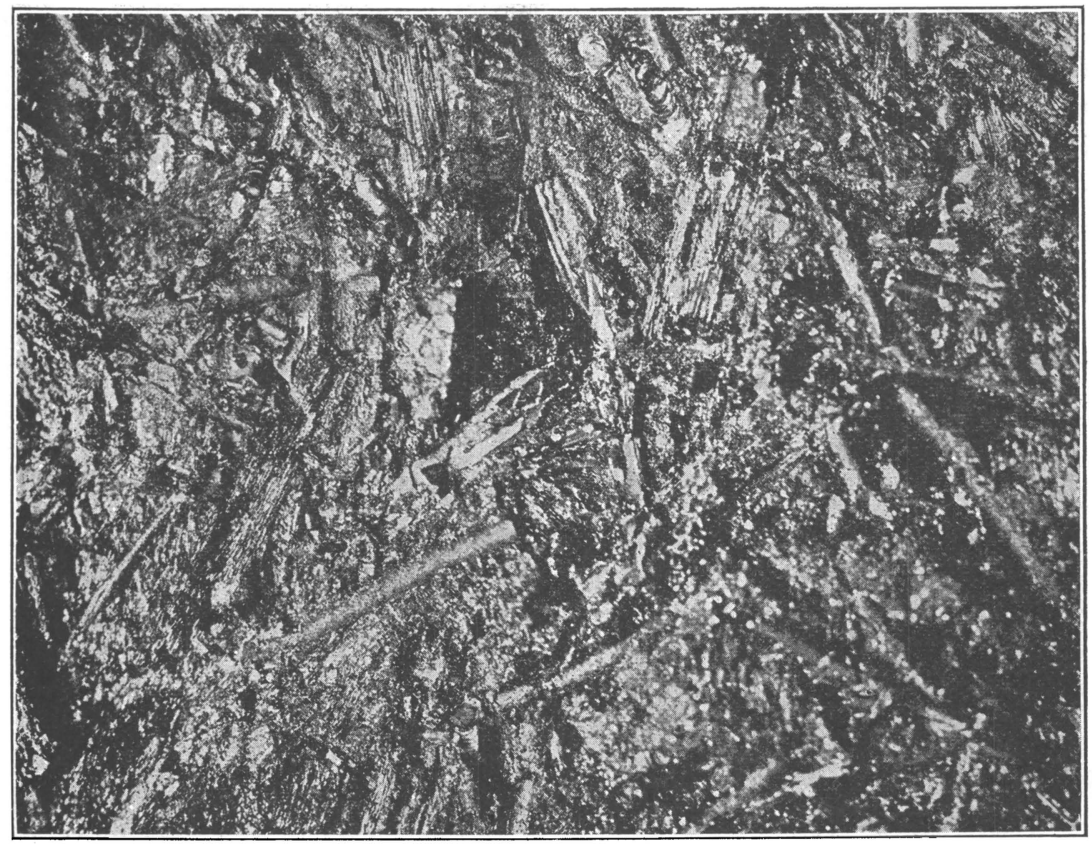

B. HORIZONTAL CLEAVAGE SURFACE OF THE COAL FROM ROYALTON, SIMILAR TO THAT ABOVE. (X 10) 


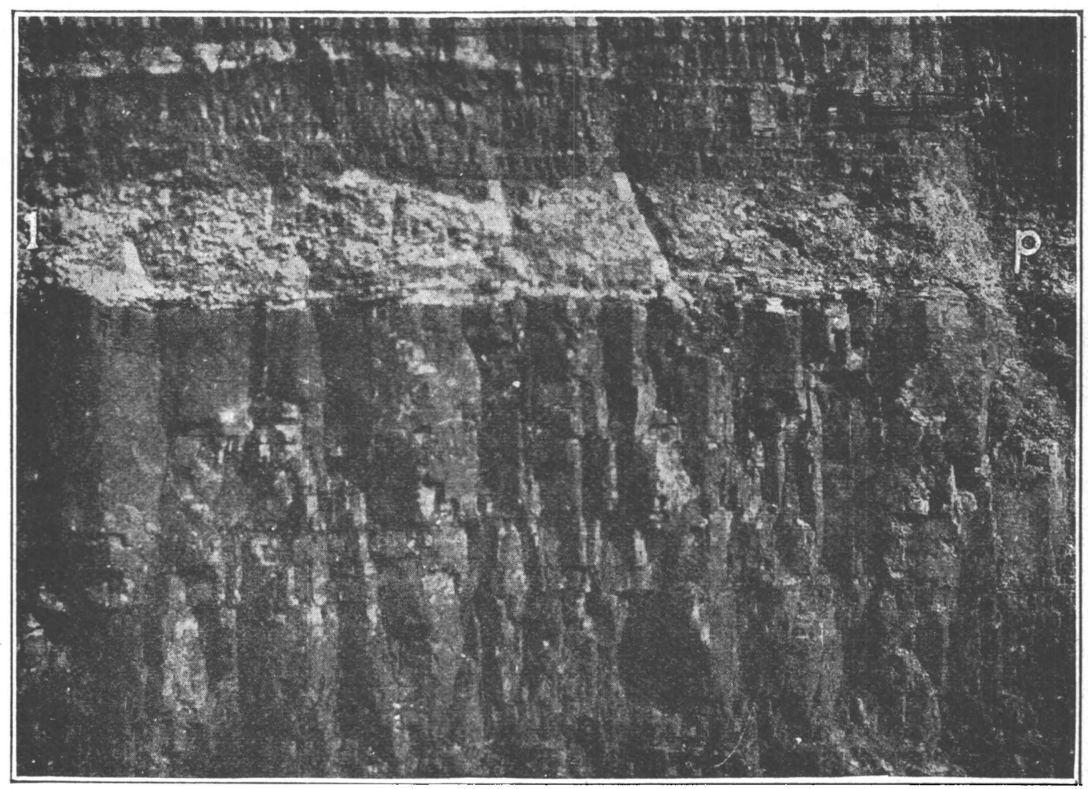

A. WHOLE SECTION OF OUTCROP OF PITTSBURGH COAL, GREATLY REDUCED.

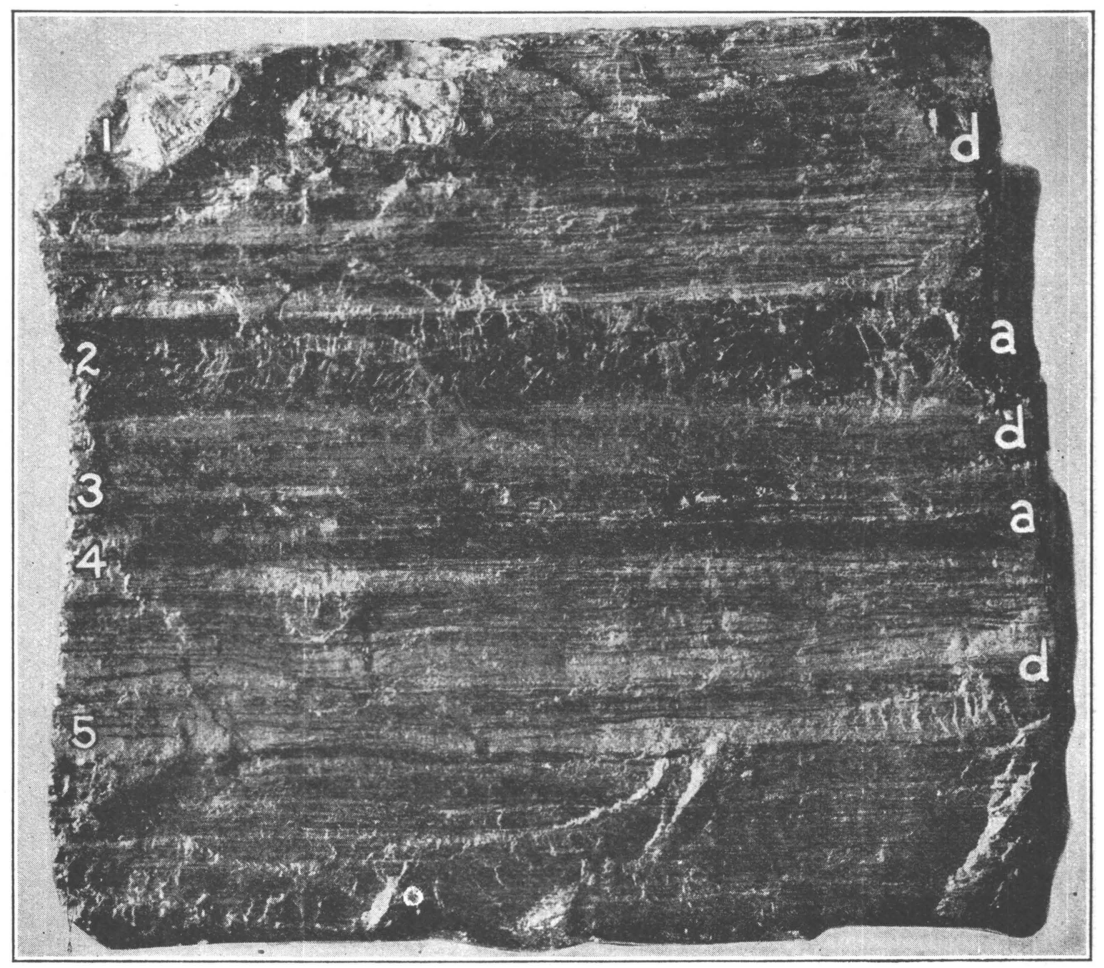




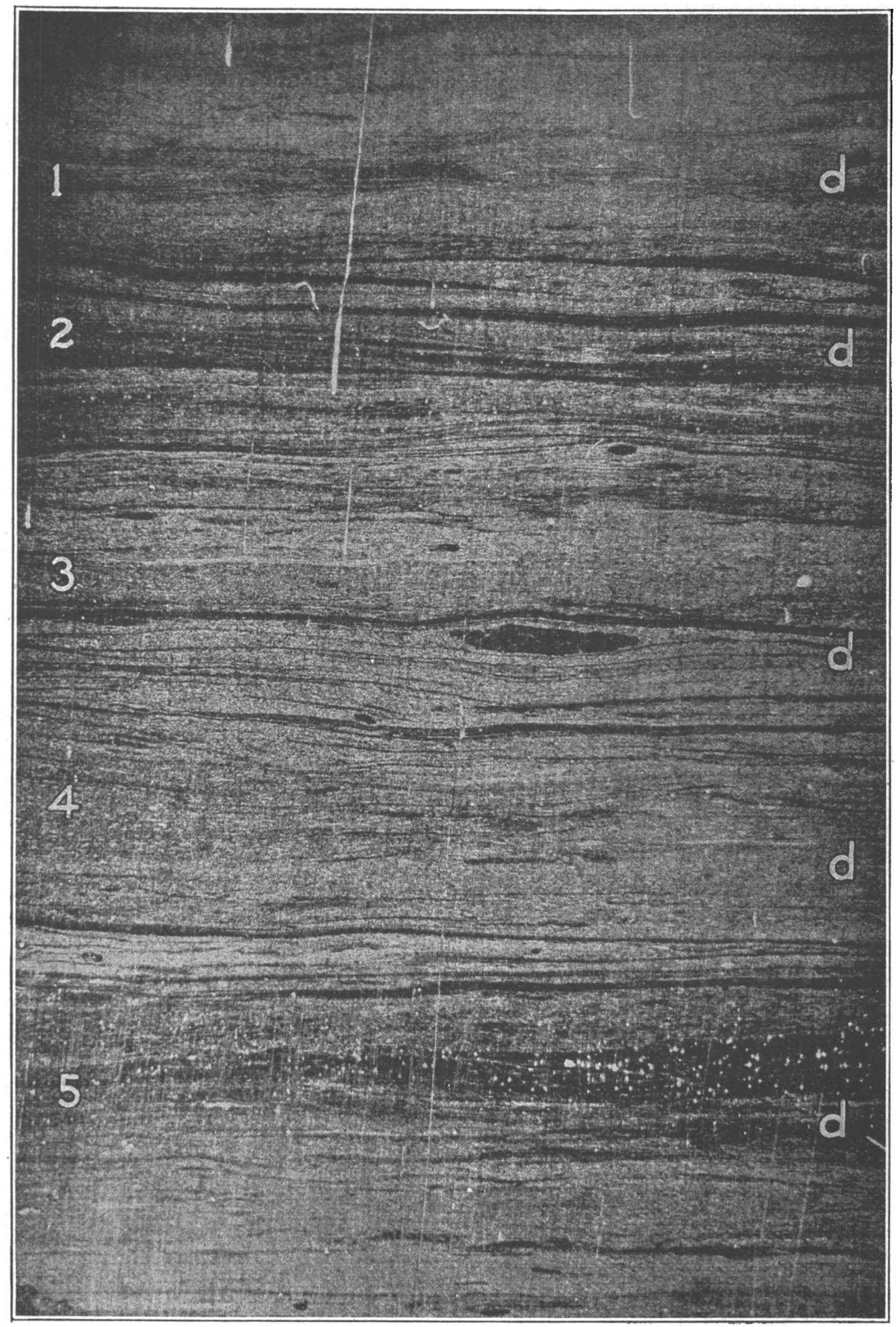

OPAQUE VERTICAL SECTION OF COAL FROM THE OAK MINE, FIRST FOOT. (X 10) 


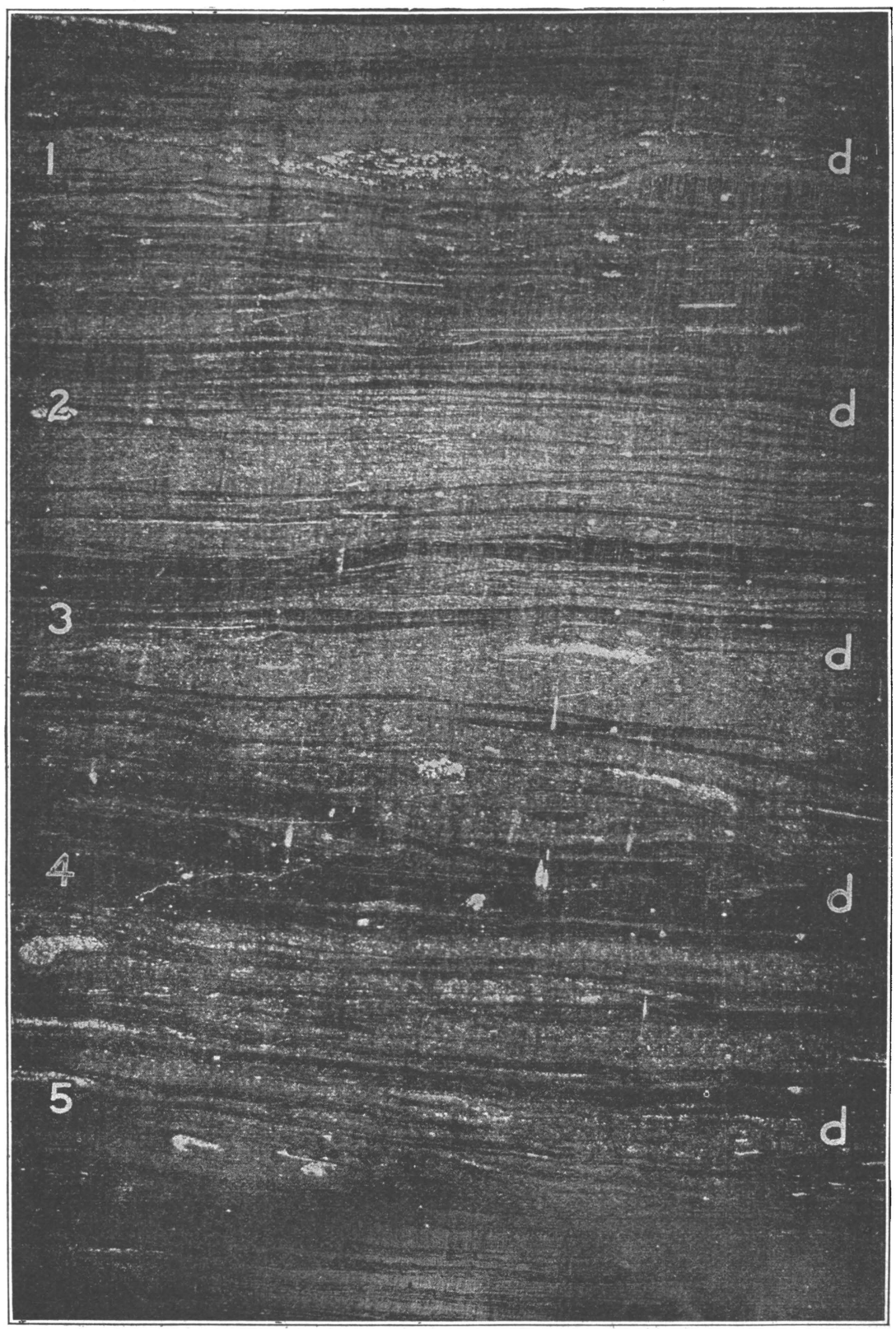

OPAQUE VERTICAL SECTION OF COAL FROM THE OAK MINE, SECOND FOOT. 


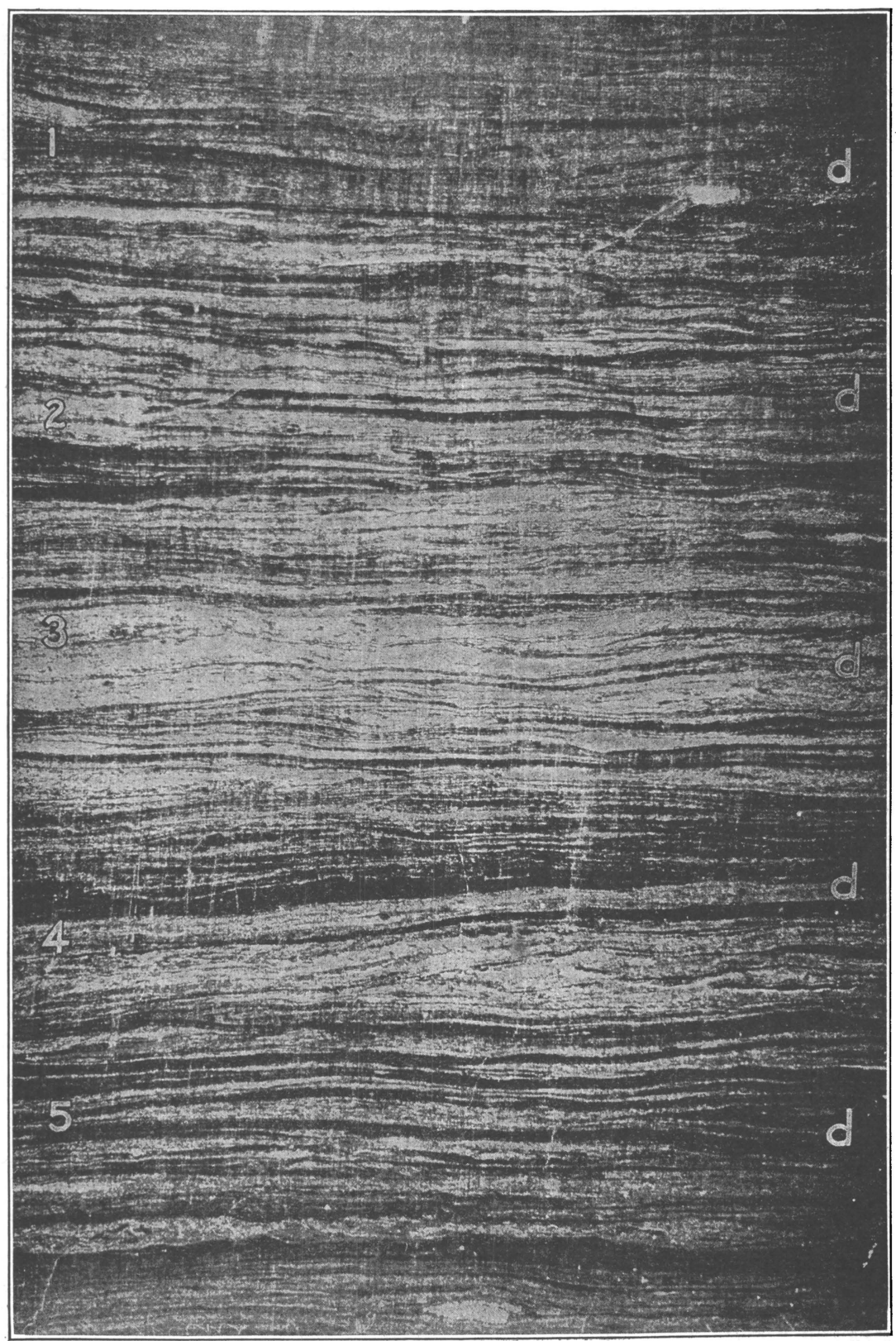

OPAQUE VERTICAL SECTION OF COAL FROM THE OAK MINE, THIRD FOOT. (X 10) $125536^{\circ}-20-$ Bull. $117-11$ 


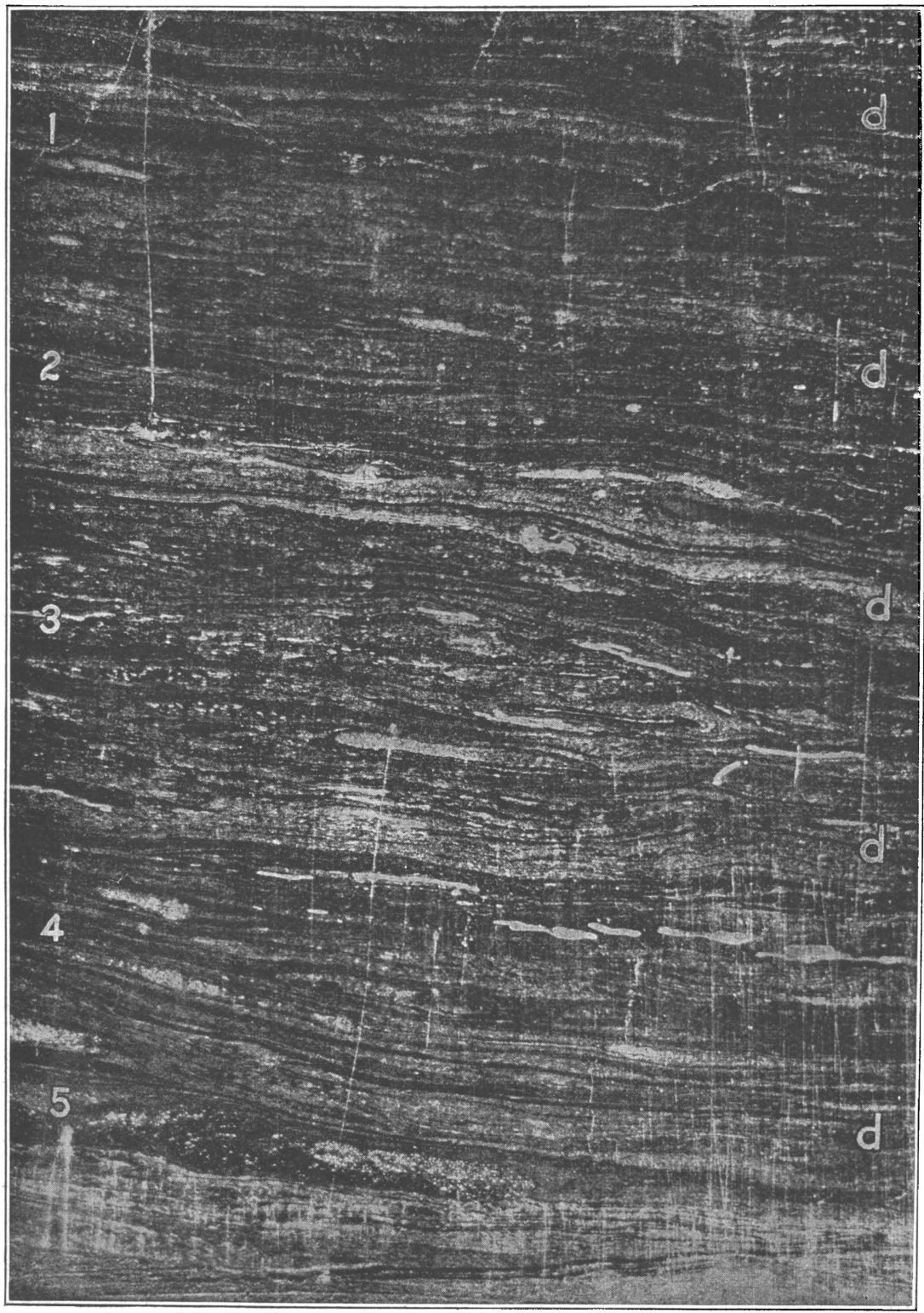

OPAQUE VERTICAL SECTION OF COAL FROM THE OAK MINE, FOURTH FOOT. 140 $(X 10)$ 


\title{
PLATE XLI.
}

\section{CONTINUED FROM PLATE XL.}

An opaque cross section of the coal from the fifth foot from the roof, or the first foot from the floor, in the Pittsburgh bed at the Oak mine. $(\times 10$.) There is a large proportion of anthraxylon. At 2-a are two very thin anthraxylon components.

\section{PLATE XLII.}

\author{
STRUCTURE OF PITTSBURGH COAL FROM THE EXPERIMENTAL MINE.
}

An opaque cross section of the coal from the Pittsburgh bed at the Experimental mine, Bruceton, Pa. $(\times 10$.$) Attritus is shown in gray, anthraxylon$ ir: black. The structure and composition is similar to that of the coal from the Oak mine just shown.

\section{PLATE XLIII.}

OPAQUE VERTICAL SECTION.

Another opaque cross section of the coal from the Pittsburgh seam at the Experimental mine, Bruceton, Pa. $(\times 10)$, showing the general structure. Some of the anthraxylon chips are almost thick enough to be recognized macroscopically as "bright coal."

\section{PLATE XLIV.}

\section{THIN VERTICAL SECTIONS.}

A. A thin cross section of the coal from the first foot from the roof of the Oak mine $(\times 10)$, photographed by means of transmitted light, showing the proportion of the anthraxylon to the attritus and the appearance of the anthraxylon at low magnification. The anthraxylon is shown as the gray bands, and the attritus in the black bands. The anthraxylon looks ragged. In the upper part is seen a carbonaceous inclusion, and in the central part smaller carbonaceous resinous nodules.

$B$. The lower half of $A(\times 20)$, showing the same components in better detail. The photographs at low magnifications by transmitted light mainly serve as intermediates between the macroscopic appearance and that at high magnifications.

NoтE.-The constituents shown in black in the photographs of thin sections are not always black or opaque in the sections, but most of them are transparent, or at best translucent and are dark red. The natural humic matter and the anthraxylon components range from orange to light red and the sporeexines from light to golden yellow, transmitting light readily. 


\section{PLATE XLV.}

\section{CONTINUED FROM PLATE XLIV.}

A. A thin section from the second foot of coal from the roof of the Oak mine $(\times 10)$, showing an anthraxylous layer in the upper half and one of relatively pure attritus in the lower half. The delicate layering of the anthraxylon components is clearly shown, with interlayers of attritus. The lighter mottling in the lower half largely represents spore matter.

$B$. A thin cross section of the coal from the Oak mine from the same horizon as $A(\times 20)$, showing the structure and nature of the components more clearly, also a considerable amount of carbonaceous matter in several places.

\section{PLATE XLVI.}

\section{CONTIN UED FROM PLATE XLV.}

A. A thin section of coal from the third foot from the roof of the Oak mine $(\times 10)$, showing a larger proportion of anthraxylon matter which is more compact than in coal from the first and second foot. The megaspore-exines and the microspore-exines are everywhere in the attritus between the anthraxylon strips.

$B$. A section similar to $A$. $(\times 20$. $)$ Laminæ of carbonaceous attritus are seen in the upper part and a resinous anthraxylon strip in the central part. The lower part shows a layer of dull coal rich in attritus, a large proportion of which is carbonaceous matter.

\section{PLATE XLVII.}

\section{CONTINUED FROM PLATE XLVI.}

A. A thin cross section from the fourth foot of the Oak mine coal $(\times 10)$, showing that the coal is more anthraxylous than at the third foot. The anthraxylon is compactly layered.

$B$. A thin cross section from the same horizon as $A(\times 20)$, showing the nature of the coal more clearly. The attritus wedged between the anthraxylous matter is similar to that shown in the coal from the other levels.

\section{PLATE XLVIII.}

\section{THIN VERTICAL SECTIONS.}

A. A thin section of coal from the fifth level from the top or the first foot from the floor at the oak mine, prepared by transmitted light. $(\times 20$. $)$ The coal from this level is not as compact as that from the third and the fourth foot levels but is very woody. The larger and the smaller megaspores are seen in the attritus. The large exines in the lower part of the photograph measure approximately 1,250 microns or $1 \frac{1}{8} \mathrm{~mm}$. across the disk.

$B$. Part of the same section as shown in Plate XLIV, $A \cdot(\times 200)$, showing two anthraxylon strips, 1-a and 3-a, and two sheets of attritus, 2-d and 4-d, layered between the anthraxylon strips, in greater detail. The cell structure and also characteristic resinous inclusions are shown in the anthraxylon strips. Spore-exines and humic matter are seen embedded in the attritus in a carbonaceous groundmass, the detail of which is not shown. 


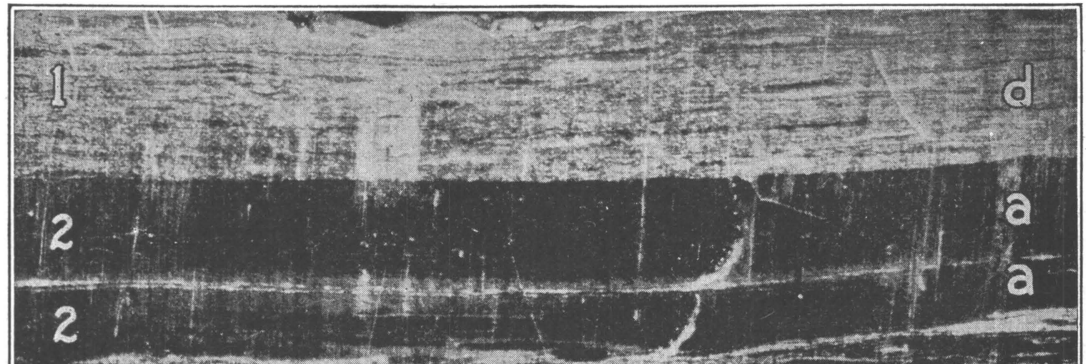

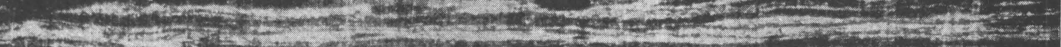

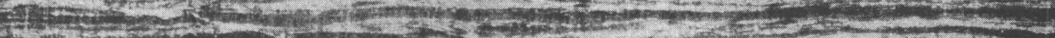

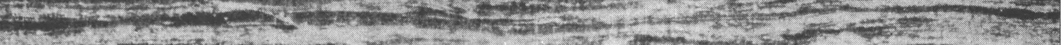

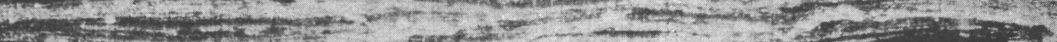

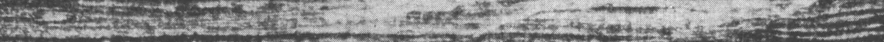

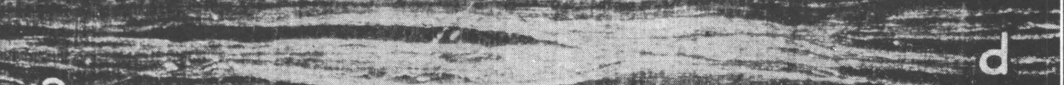

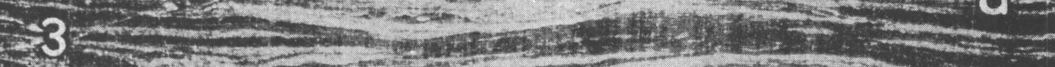

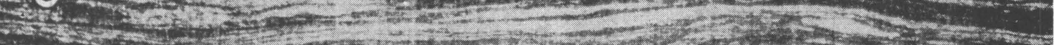

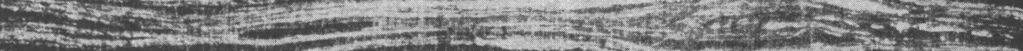
T.7.

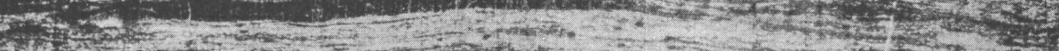

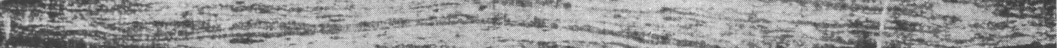
y: 1 (n)

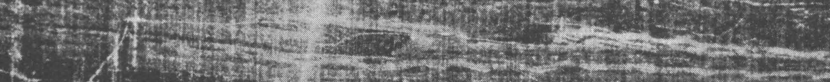<smiles>[Te]</smiles>

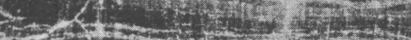

3.6.

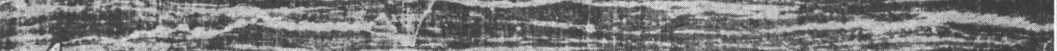

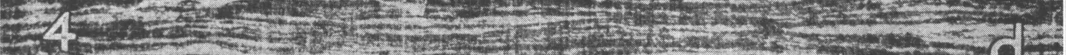

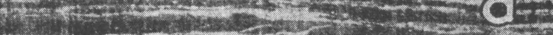

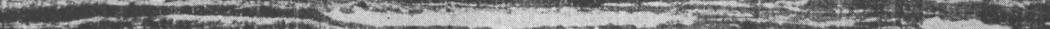

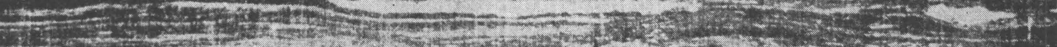

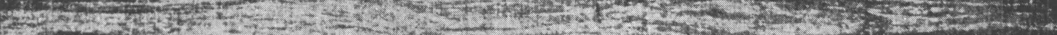
- 1. 2. t

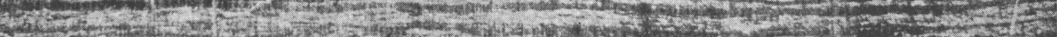

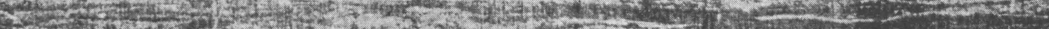

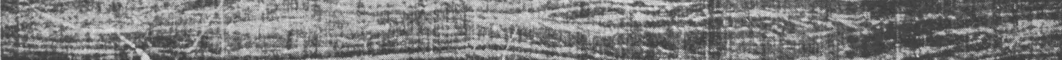

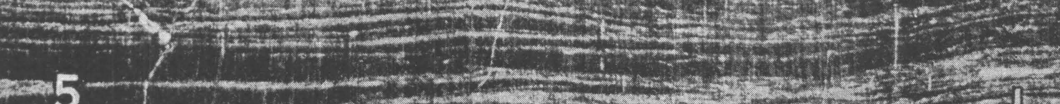

L

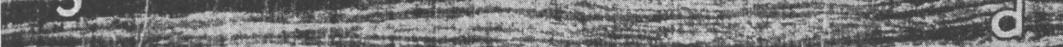

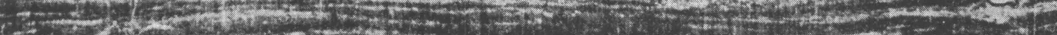

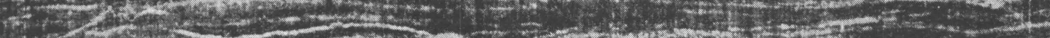

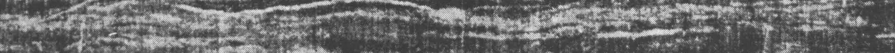

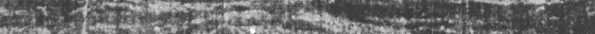
Heat 2 -

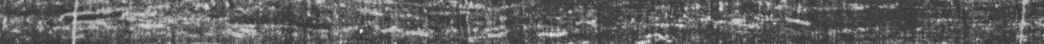

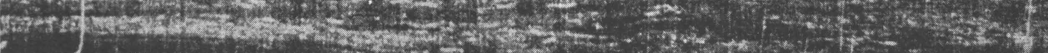

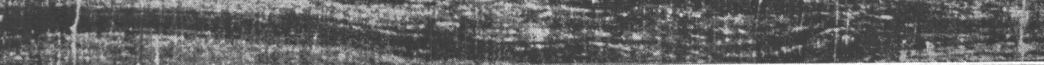

OPAQUE VERTICAL SECTION OF COAL FROM THE OAK MINE, FIFTH FOOT. (X 10) 


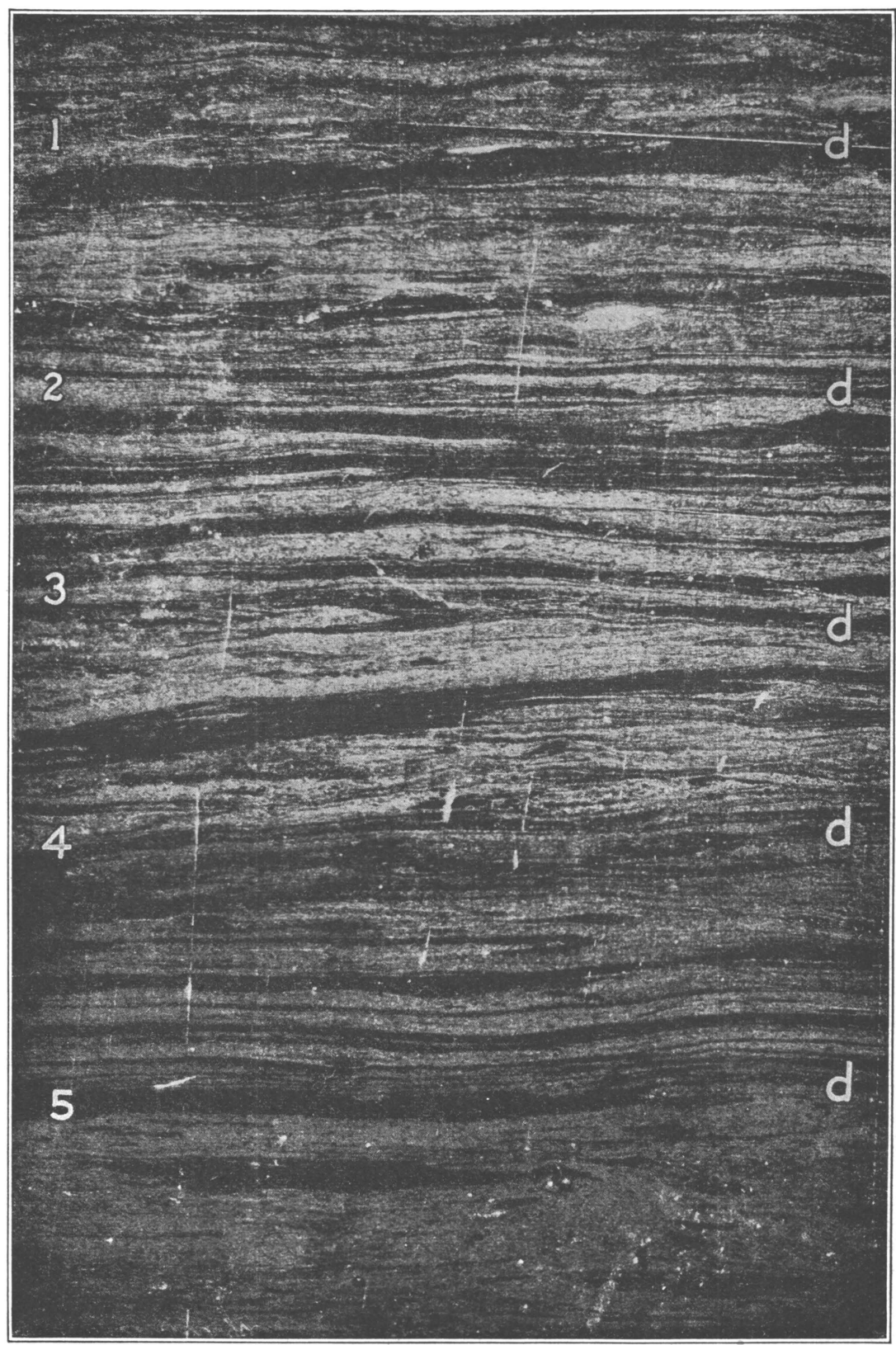

OPAQUE VERTICAL SECTION OF COAL FROM THE EXPERIMENTAL MINE. 144 (X 10) 


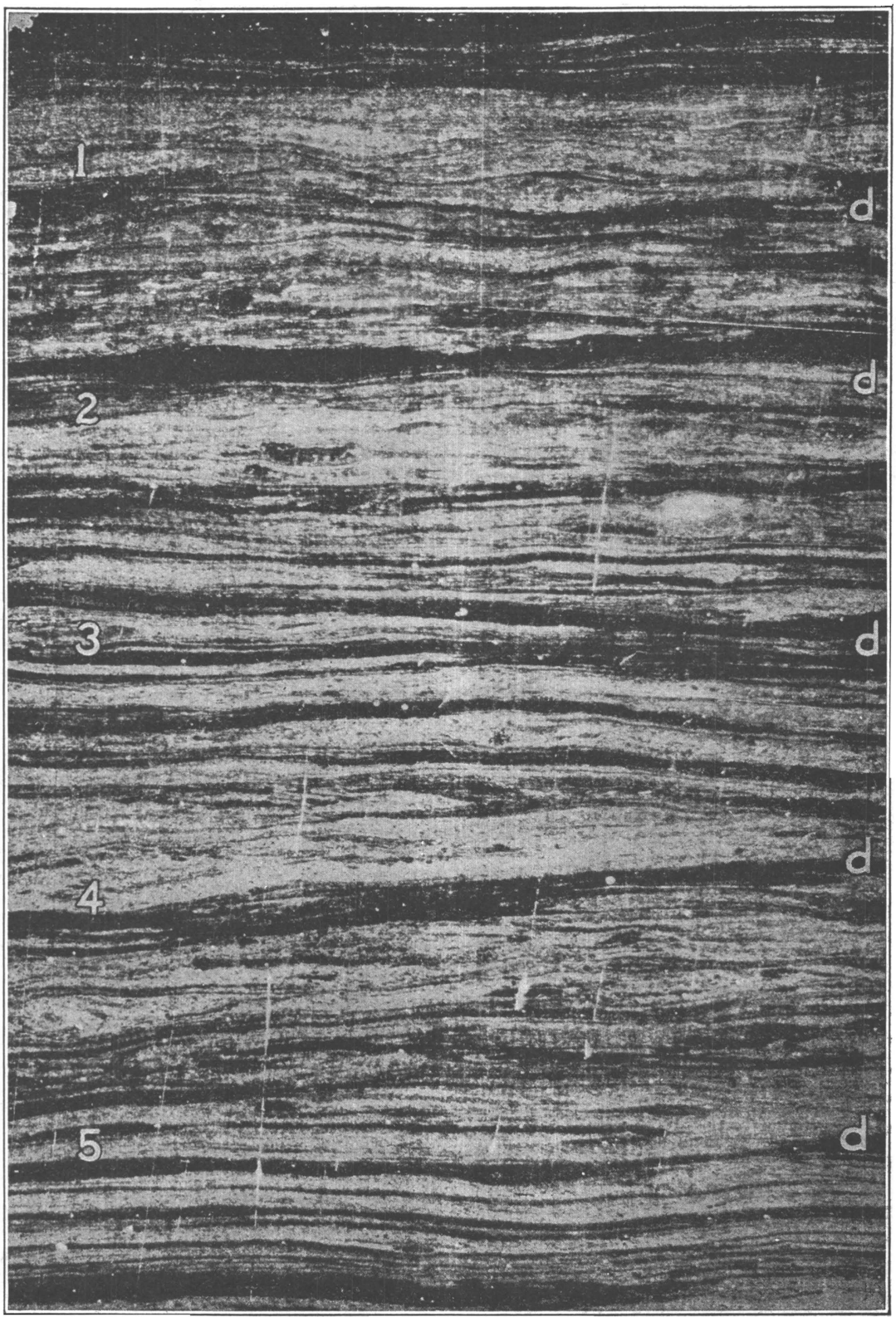

ANOTHER OPAQUE VERTICAL SECTION OF COAL FROM THE EXPERIMENTAL MINE. (X 10) 


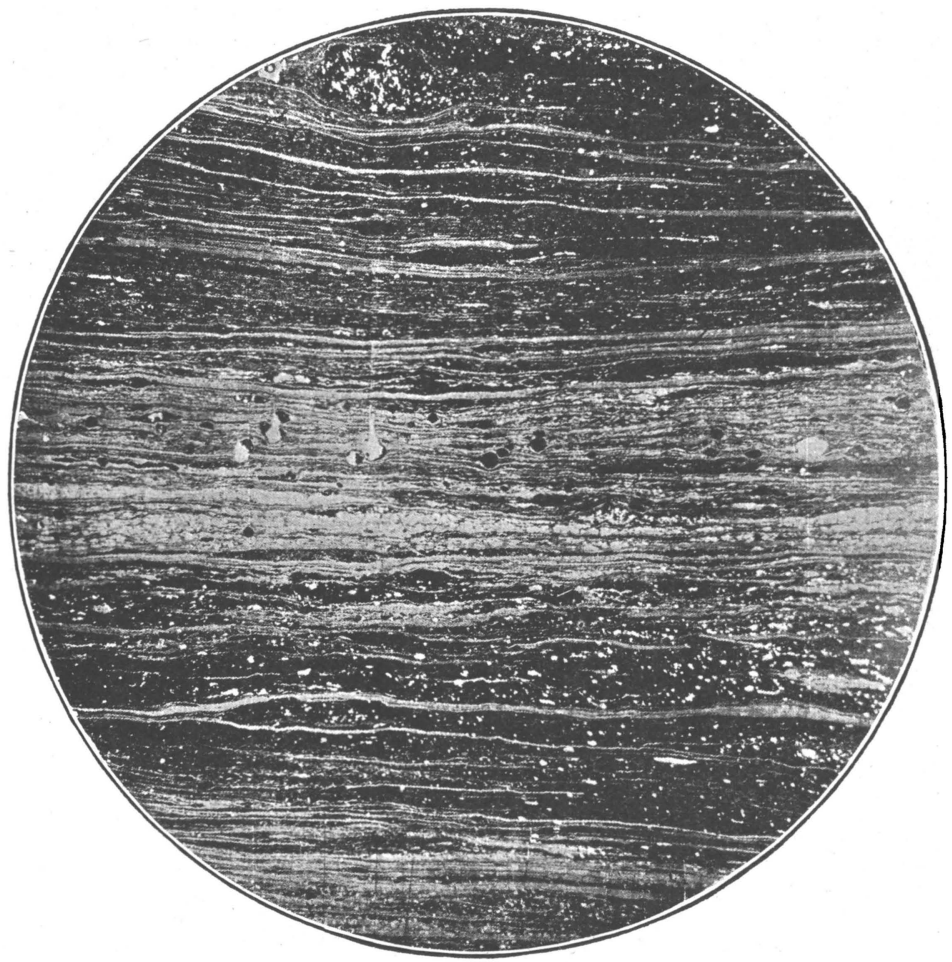

A. THIN VERTICAL SECTION OF COAL ( $X 10)$ FROM THE OAK MINE, FIRST FOOT.

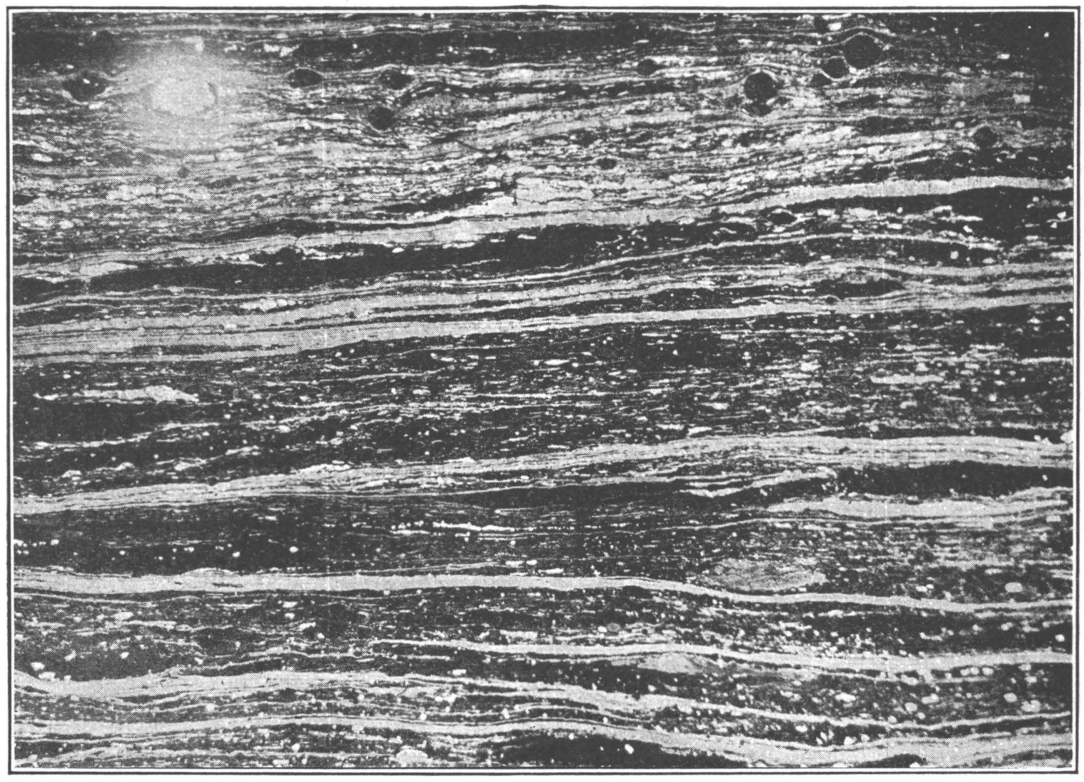

B. THIN VERTICAL SECTION OF COAL (X 20) FROM THE OAK MINE, FIRST FOOT. 


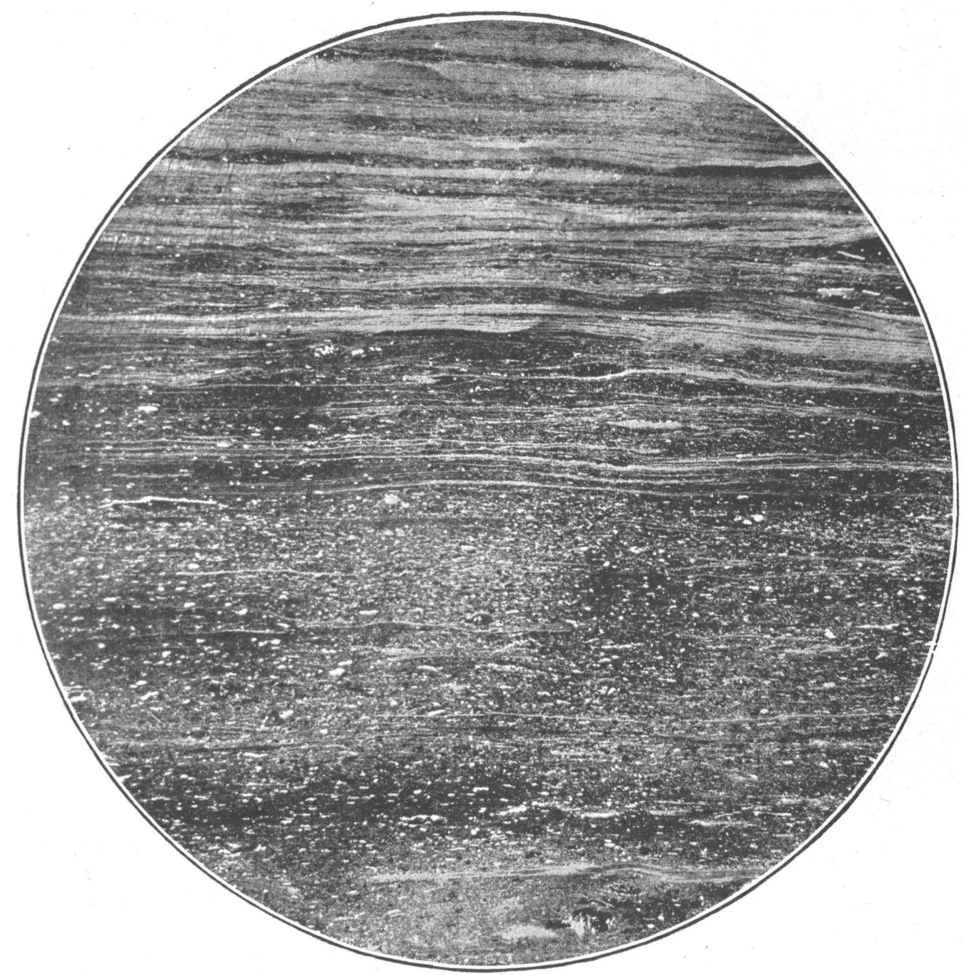

A. THIN VERTICAL SECTION OF COAL (X 10) FROM THE OAK MINE, SECOND FOOT.

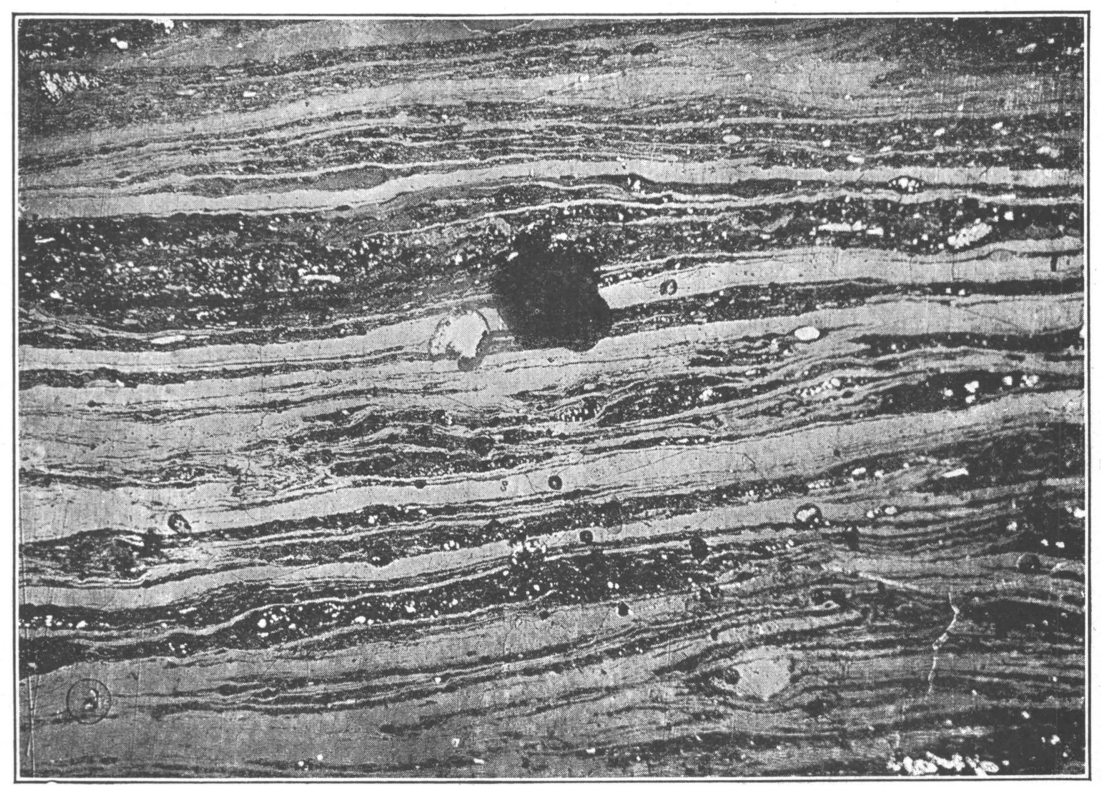

B. THIN VERTICAL SECTION OF COAL (X 20) FROM THE OAK MINE, SECOND FOOT. 


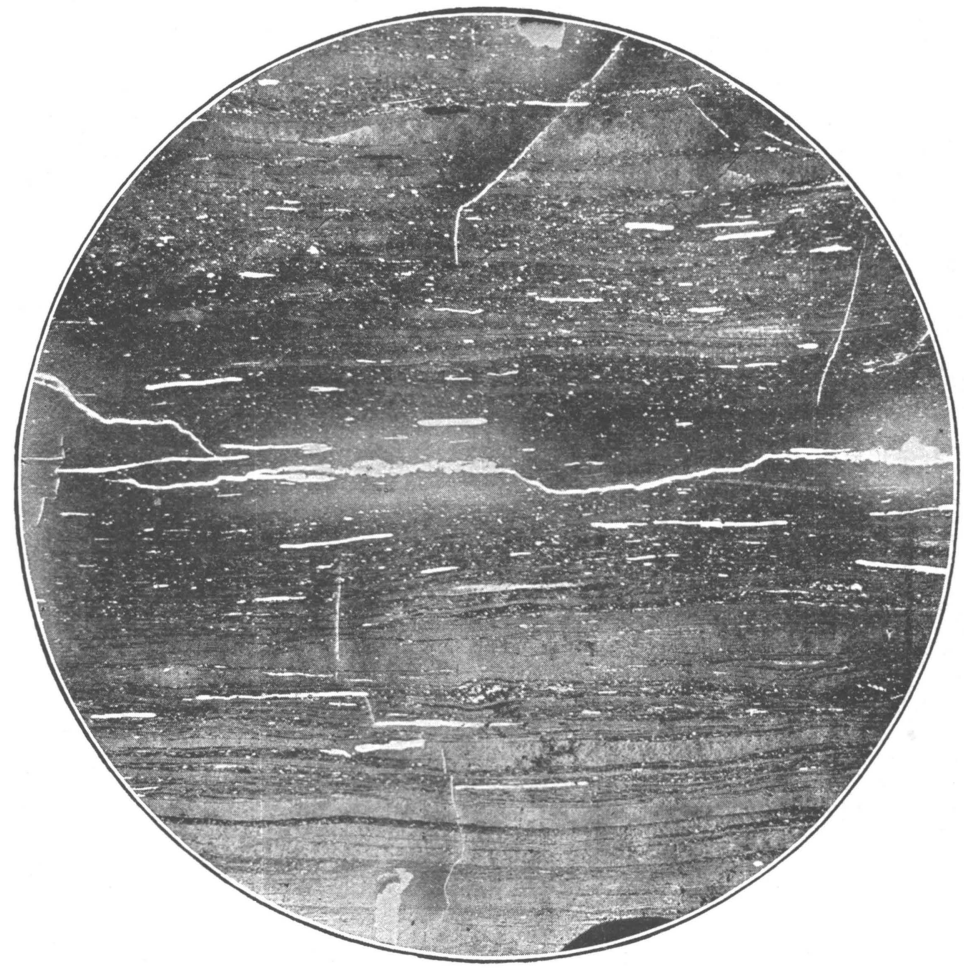

A. THIN VERTICAL SECTION OF COAL (X 10) FROM THE OAK MINE, THIRD FOOT

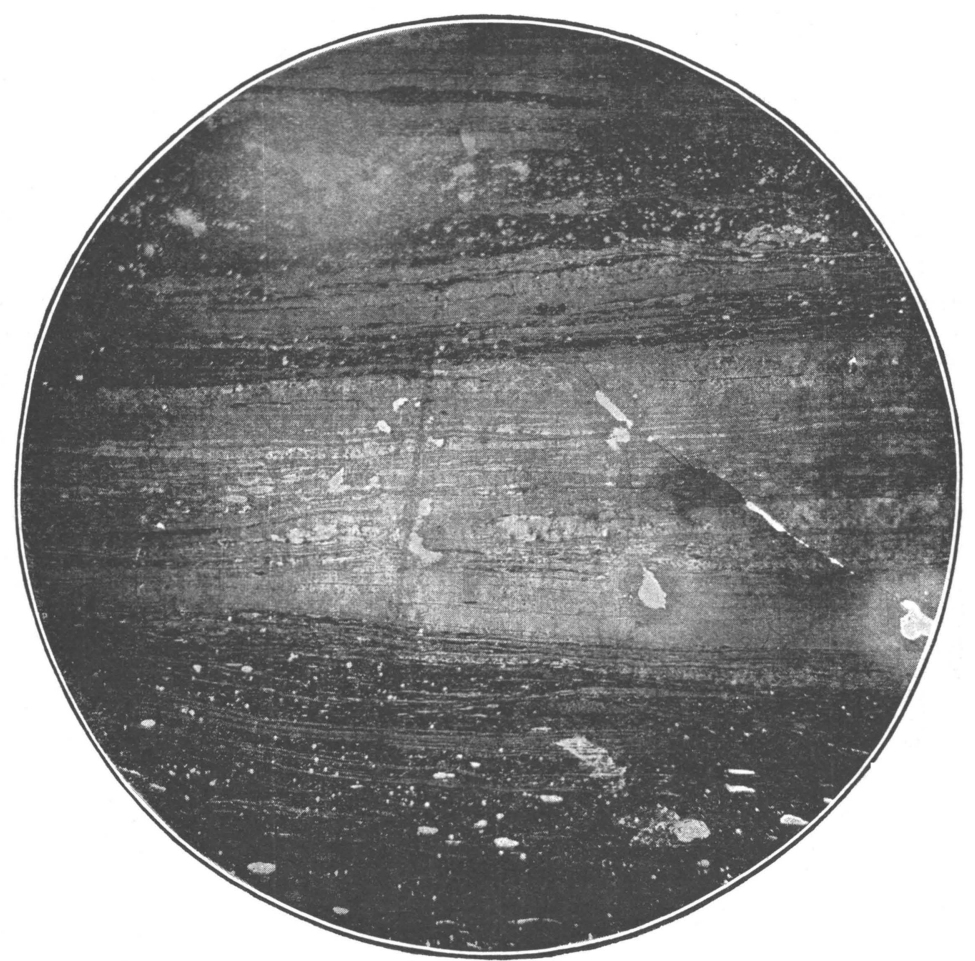

B. THIN VERTICAL SECTION OF COAL (X 20) FROM THE OAK MINE, 148 THIRD FOOT. 


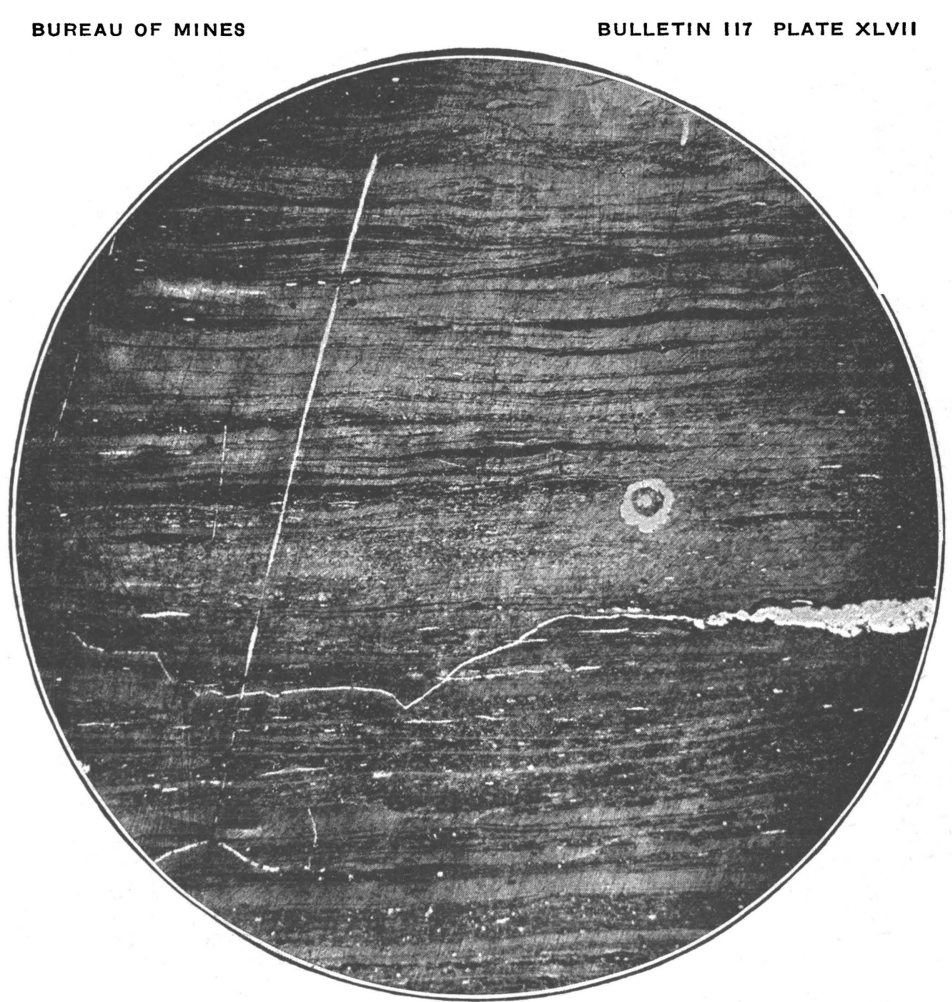

A. THIN VERTICAL SECTION OF COAL (X 10) FROM THE OAK MINE, FOURTH FOOT.

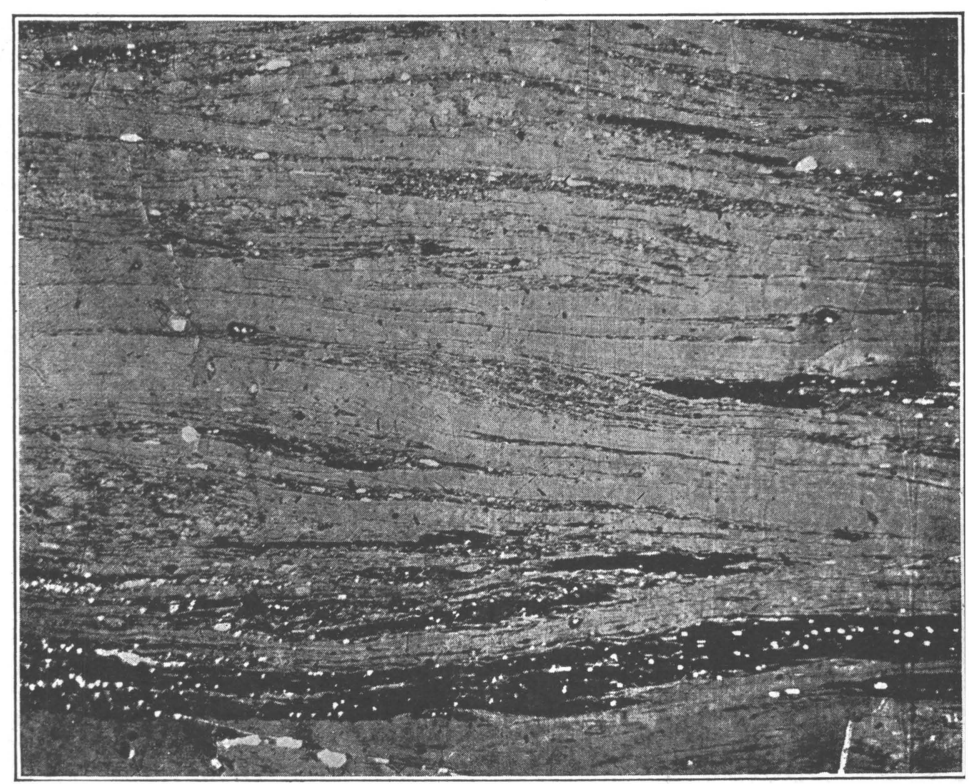

B. THIN VERTICAL SECTION OF COAL (X 20) FROM THE QAK MINE, FOURTH FOOT. 


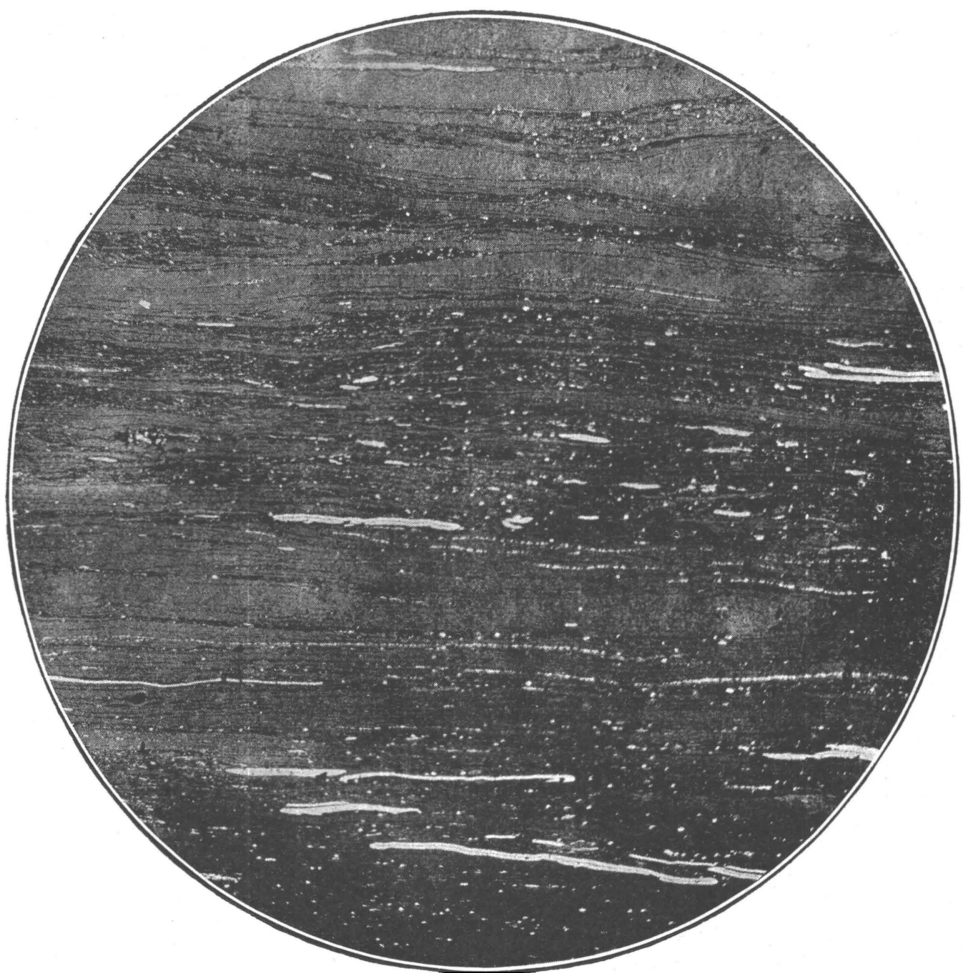

A. THIN VERTICAL SECTION OF COAL (X 20) FROM THE OAK MINE, FIFTH FOOT.

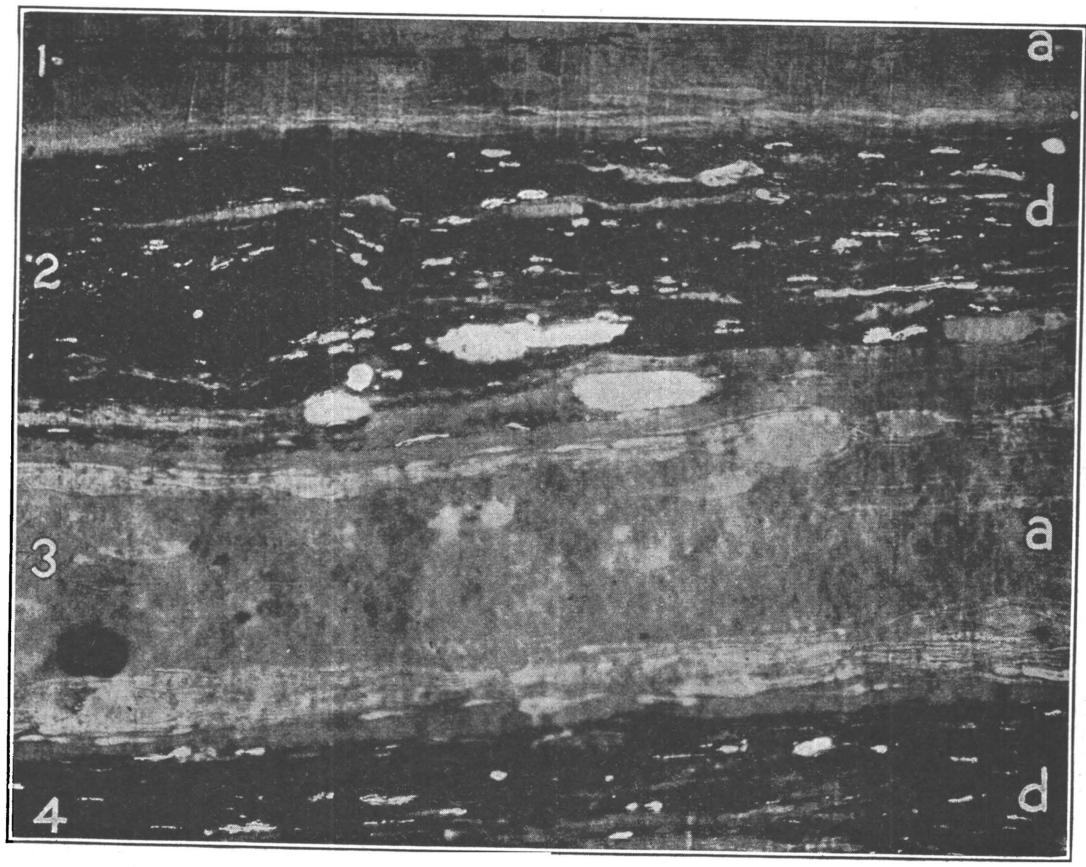




\section{PLATE XLIX.}

\section{THIN VERTICAL SECTIONS.}

A. Part of the section shown in Plate XLIV, A. $(\times 200$. $)$ At $1-r$ is a strip of resinous anthraxylon resting on a less resinous part, 2-a. At 3-a is anthraxylon, including resinous matter, in which the original cell structure is still recognizable; similar structures are found at 6-a; at 5-d is a sheet of attritus rich in carbonaceous matter, including a few resinous particles, some humic and some spore matter.

$B$. A layer of dull coal from the same section shown in $A(\times 200)$, composed of humic, carbonaceous, earthy, and spore matter, and a considerable number of large resinous particles, including the thin anthraxylon strips, 2-a, 4-a, and 5-a, and a somewhat thicker strip with resinous inclusions, 6-a and 7-a. The original cell structure of the anthraxylon strips is still recognizable. The attritus at $3-d$ is rich in carbonaceous matter.

\section{PLATE L.}

\section{THIN VERTICAL SECTIONS.}

A. A thin cross section of coal, in the second foot from the roof of the Oak mine $(\times 200)$, representing a layer of attritus; largely composed of humic matter, some spore matter, some resinous matter, a considerable number of large carbonaceous particles and considerable finely divided carbonaceous matter.

$B$. Another section from the second-foot level of the Oak mine coal $(\times 200)$, representing attritus in which are embedded strips of anthraxylon, 3-a, 5-a, and 7-a, and many megaspores, these being very numerous at $1-\mathrm{sp}$. The width of the megaspores is approximately 75 to 100 microns, or about one-tenth of a millimeter.

\section{PLATE LI.}

\section{THIN VERTICAL SECTIONS.}

A. A cross section of coal from the second foot from the roof of the Oak mine $(\times 200)$, showing a layer of attritus mainly composed of spore-exines embedded in a mass of humic and carbonaceous matter, not well differentiated in this photograph.

$B$. A part of the section included in $A(\times 1,000)$, showing the constituents in detail. The spore-exines are shown here in cross section as irregular crenulated areas. The matrix between the spore-exines is seen to consist of humic and carbonaceous matter. A few resinous particles are present. The humic matter is gray, and the carbonaceous black. Note the minute size of the area represented in this photograph, less than $0.1 \mathrm{~mm}$., or about one two-hundredand-fortieth inch.

\section{PLATE LII.}

\section{THIN VERTICAL SECTIONS.}

A. A cross section prepared from the second foot of coal of the Oak mine $(\times 200)$, showing an anthraxylous layer with some attritus included at $2-d$, $4-d$, and $7-d$. Notice the row of cells below 4-d, the remains of spiral vessels at $6-\mathrm{a}$, and a cuticle at $5-\mathrm{c}$.

$B$. Another cross section from the same level as $A$, showing a large number of thin strips of anthraxylon embedded in an attritus rich in carbonaceous matter, much of which consists of large particles $(\times 200)$. 


\section{PLATE LIII.}

\section{THIN VERTICAL SECTIONS.}

A. Area from Plate XLIV, $A(\times 200)$, showing a layer of attritus including thin strips of anthraxylon, 1-a and 3-a, and a number of carbonaceous particles. The attritus is composed of spore-exines, humic matter, and much carbonaceous matter. The oval area in $2-\mathrm{d}$ represents a lump of spore-exines intimately united.

B. From an area included in Plate XLIV, $A(\times 1000)$, showing the attritus in detail. The exines in cross section appear crenulated. Note the megaspore in the upper part.

\section{PLATE LIV.}

\section{THIN VERTICAL SECT̃IONS.}

A. A thin cross section from the second foot of coal from the Oak mine $(\times 200)$, containing much granular humic matter and thin anthraxylon strips. The proportion of the spore matter, the carbonaceous matter, and the humic matter is shown.

$B$. A thin cross section from the second foot of coal from the Oak mine $(\times 200)$, showing the nature and structure of the anthraxylon chips and the distribution of carbonaceous matter and spore-exines. The cell structure in the anthraxylon is largely, although not altogether, effaced.

\section{PLATE LV.}

\section{THIN VERTICAL SECTIONS.}

A. A thin cross section $(\times 200)$ from the third foot from the roof of the Oak mine, representing an anthraxylous layer. The cell remains at 2-a are clearly shown, but at 3-a they are recognizable only as thin striations.

$B$. A thin section of the coal $(\times 200)$ from the third foot from the roof of the Oak mine, representing thin anthraxylon chips, 1-a and 3-a, embedded in the attritus. The attritus is rich in carbonaceous matter at $2-d$. The cell structure in the anthraxylon is everywhere clearly seen.

\section{PLATE LVI.}

\section{THIN VERTICAL SECTIONS.}

A. A thin cross section of coal in the fourth foot from the top, at the Oak mine $(\times 200)$, showing a peculiar type of tissue very common at this level. At 1-d is shown a strip of granular resinous matter.

$B$. A thin cross section in the fourth foot of coal from the roof, at the Oak mine $(\times 200)$, showing at 1 -ad a layer of comminuted anthraxylon, at $2-a$ the same kind of tissue as shown in Plate LVI, $A$, and at 3-a and 4-a compact anthraxylon including some resinous particles. Only a few spore-exines are seen in the attritus. 


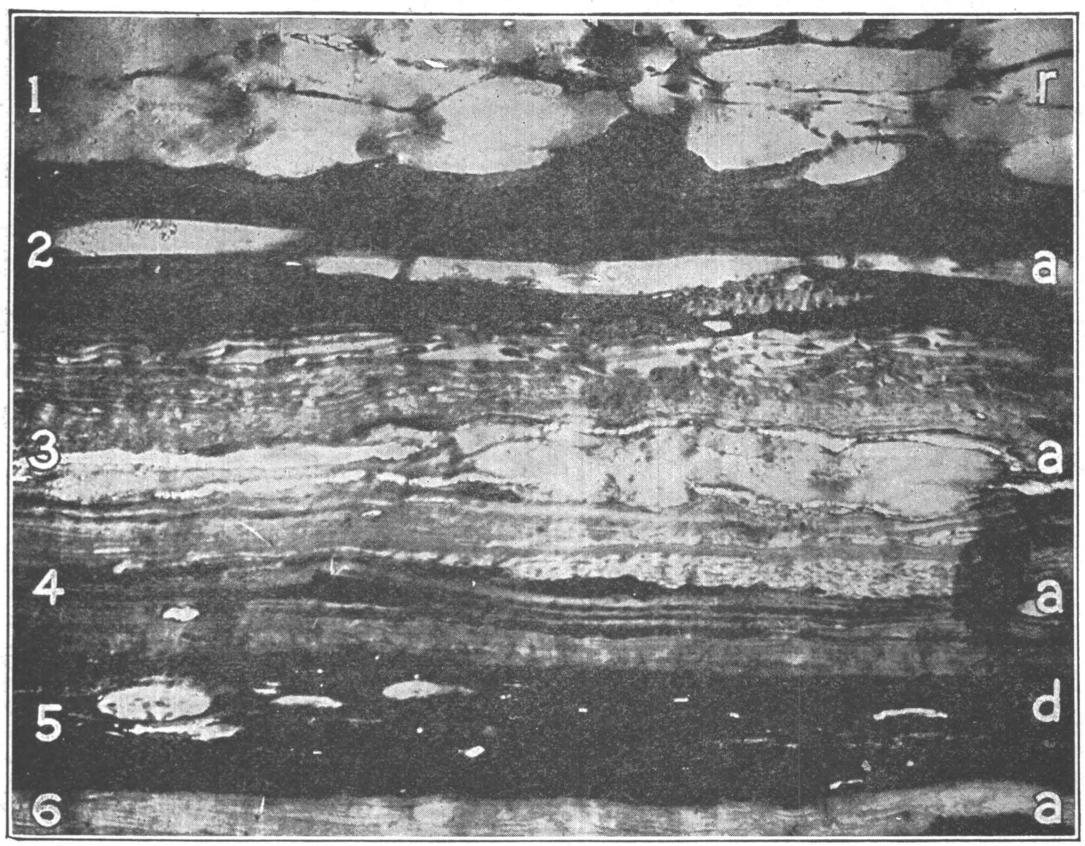

$A$. PART OF SECTION SHOWN IN PLATE XLIV, $A$, (X 200)

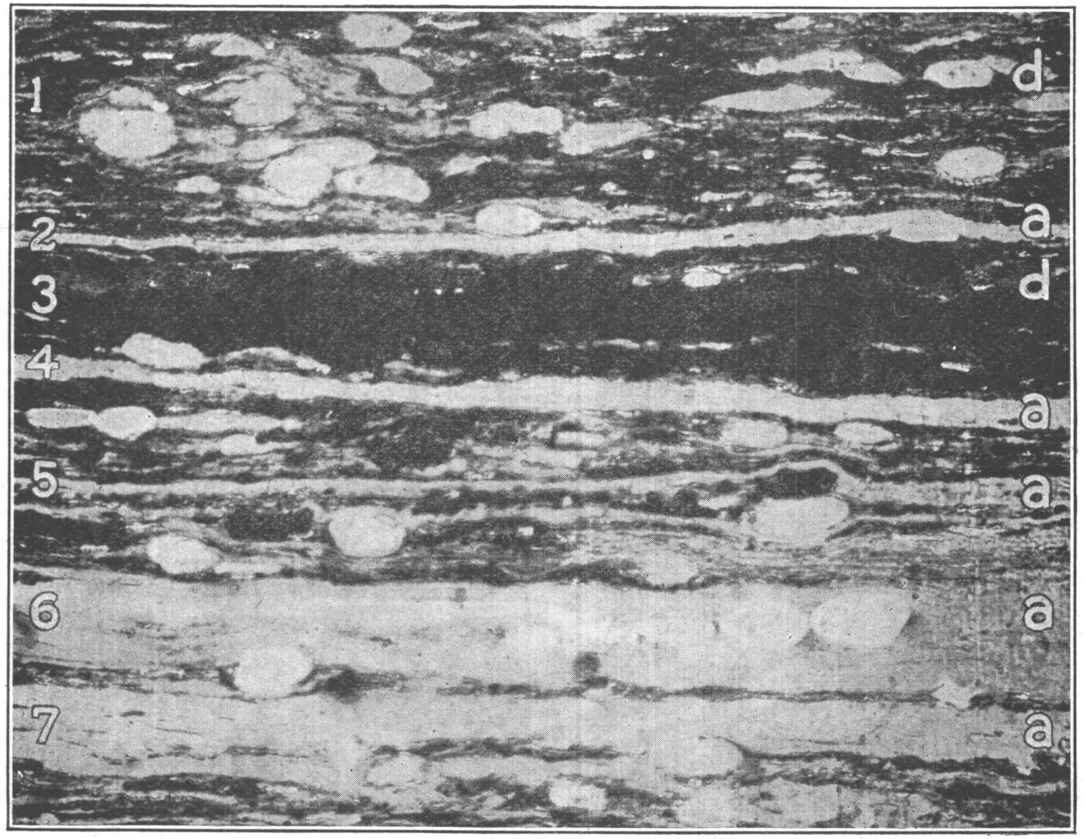

$B$. LAYER OF DULL COAL FROM THE SAME SECTION SHOWN IN PLATE XLIV, $A$. (X 200) 


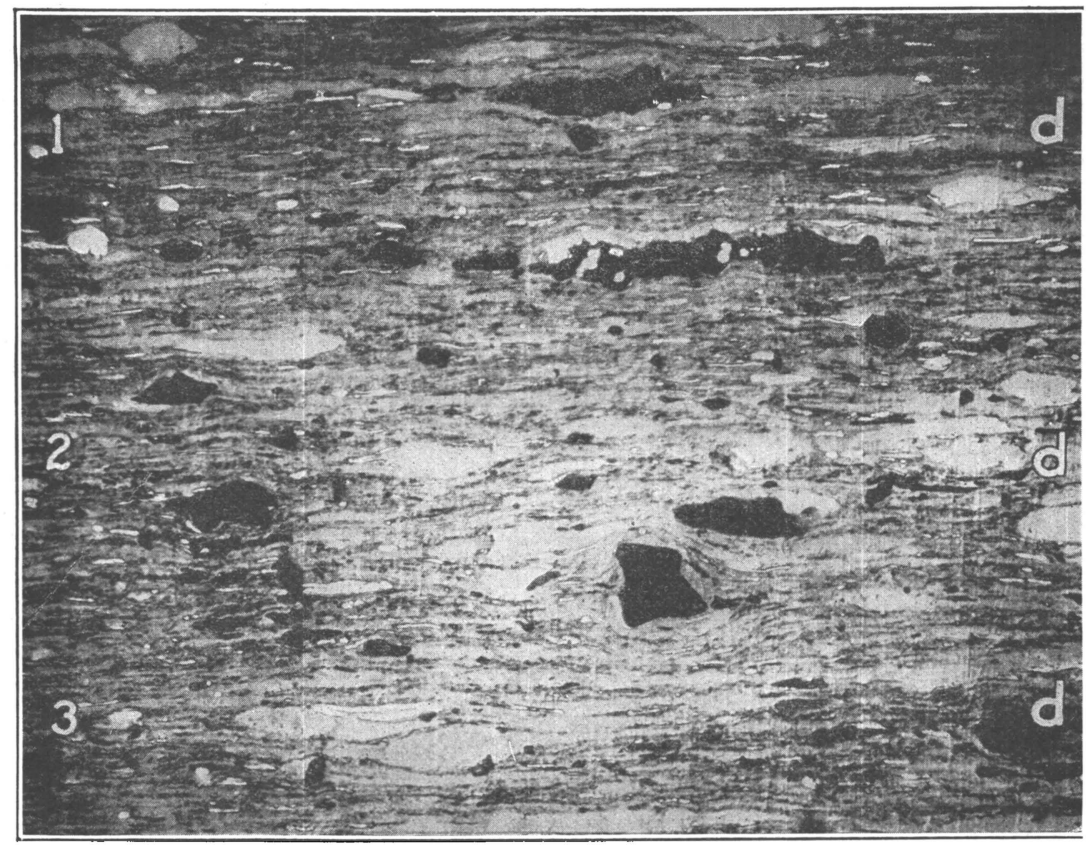

A. THIN VERTICAL SECTION OF COAL (X 200) FROM THE OAK MINE, SECOND FOOT.

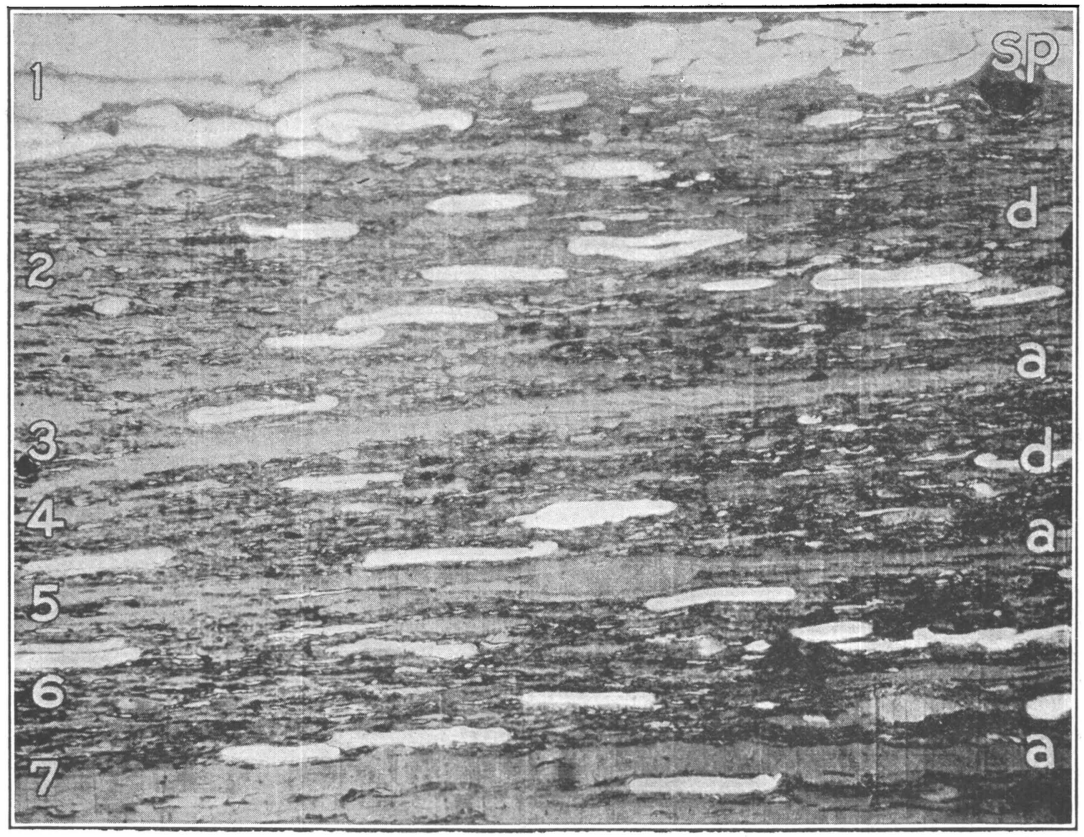

B. ANOTHER THIN VERTICAL SECTION OF SAME COAL AS ABOVE. (X 200) 


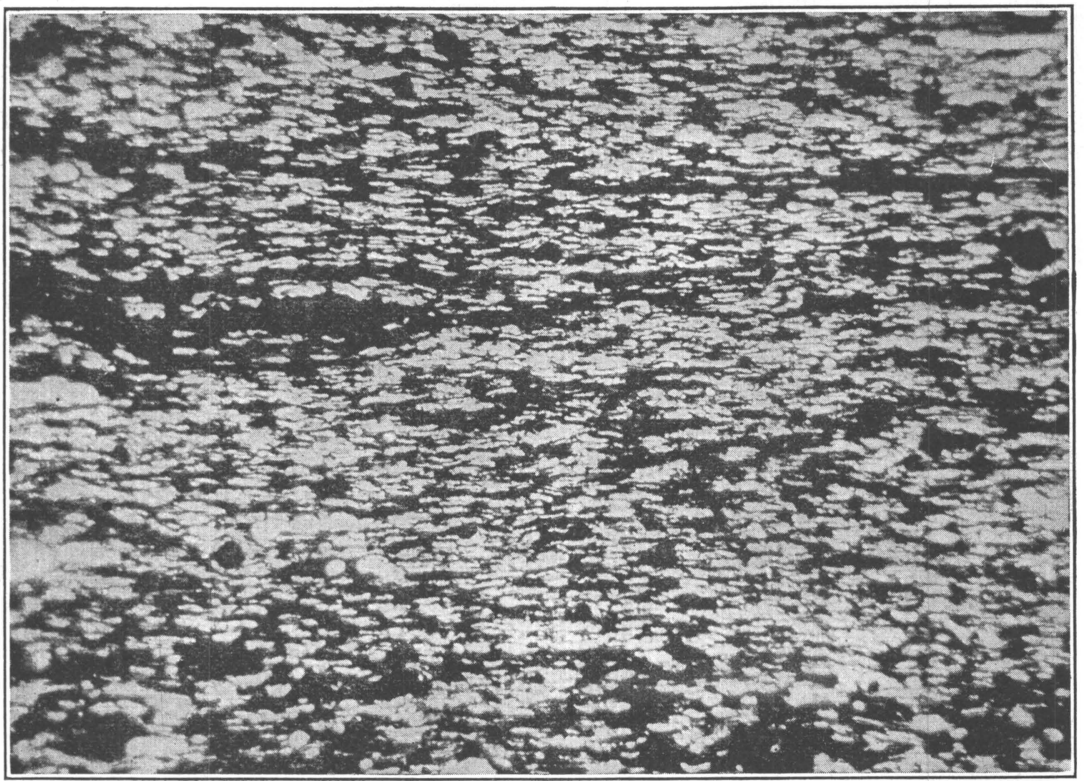

A. THIN VERTICAL SECTION OF COAL (X 200) FROM THE OAK MINE, SECOND FOOT.

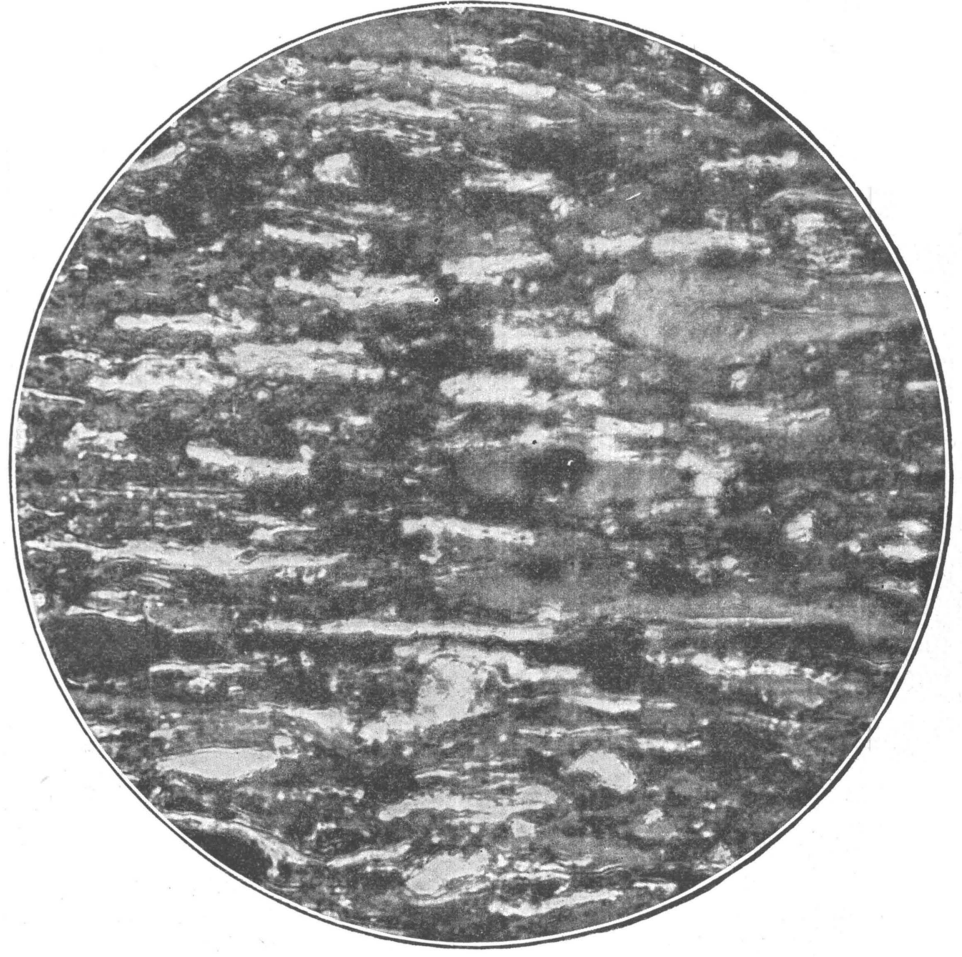

B. PART OF SECTION SHOWN ABOVE. (X 1000) 


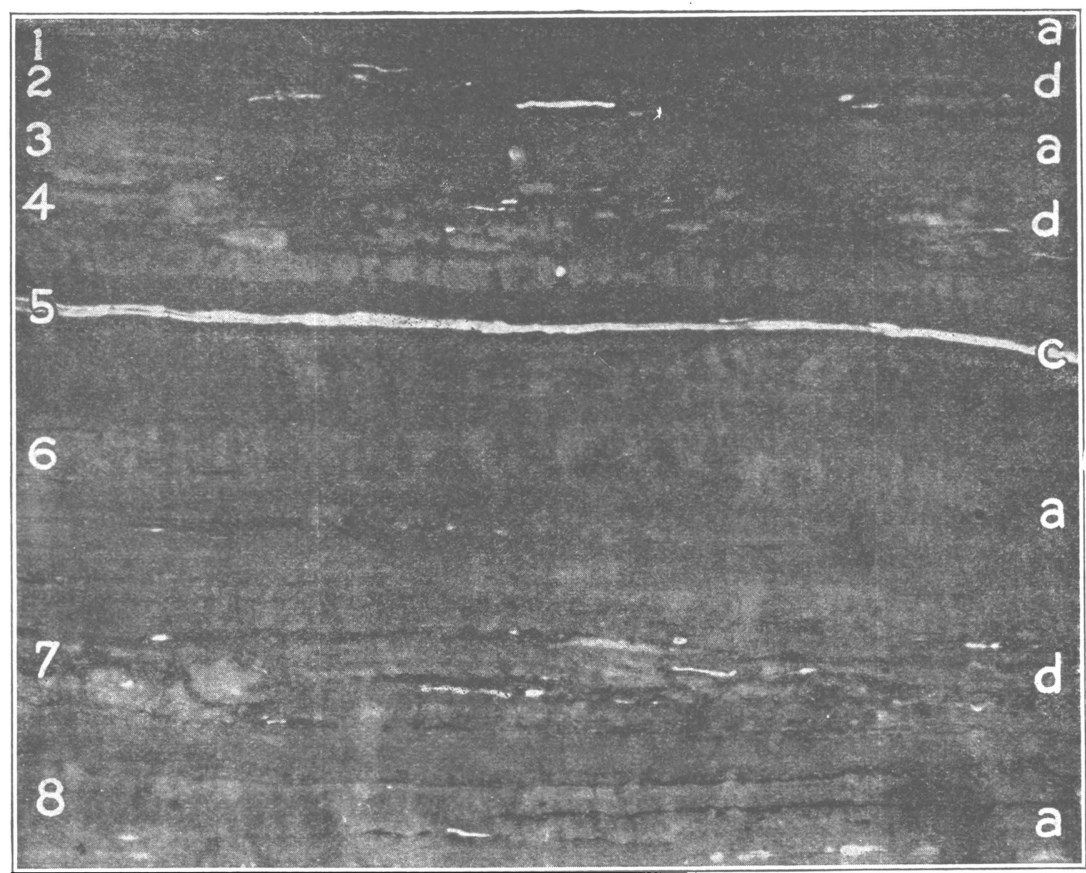

A. THIN VERTICAL SECTION OF COAL (X 200) FROM THE OAK MINE, SECOND FOOT.

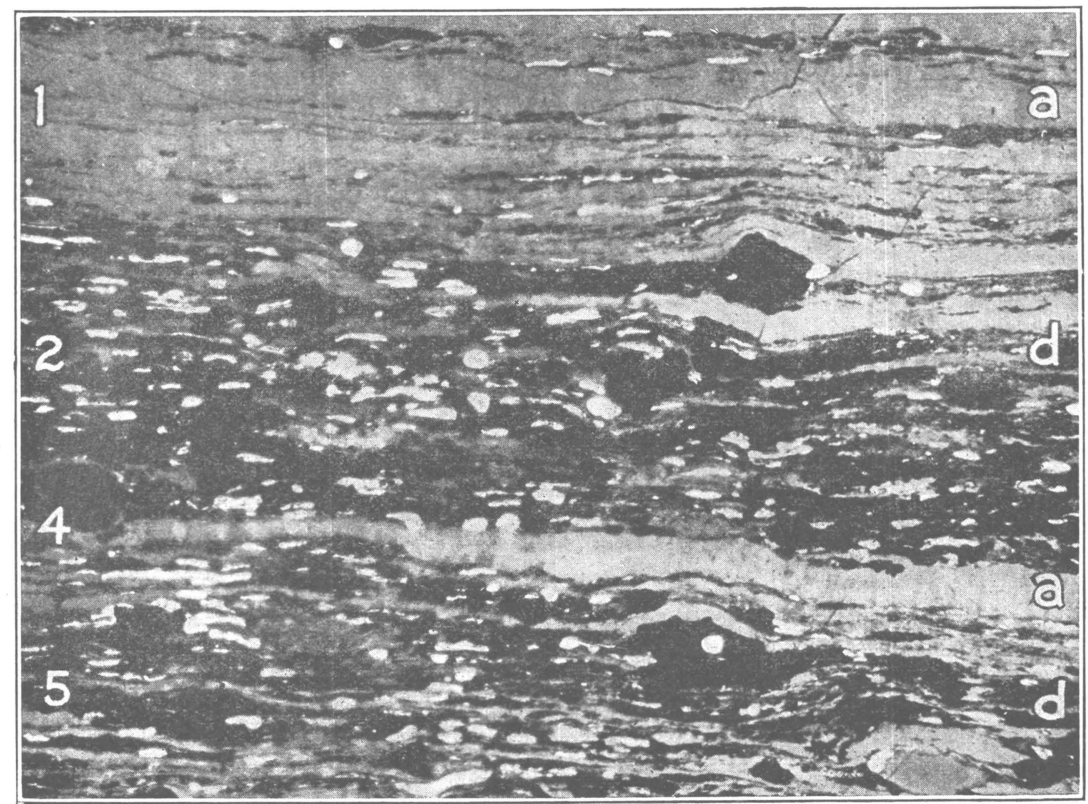

B. ANOTHER CROSS SECTION FROM SAME COAL AS ABOVE. (X 200) 


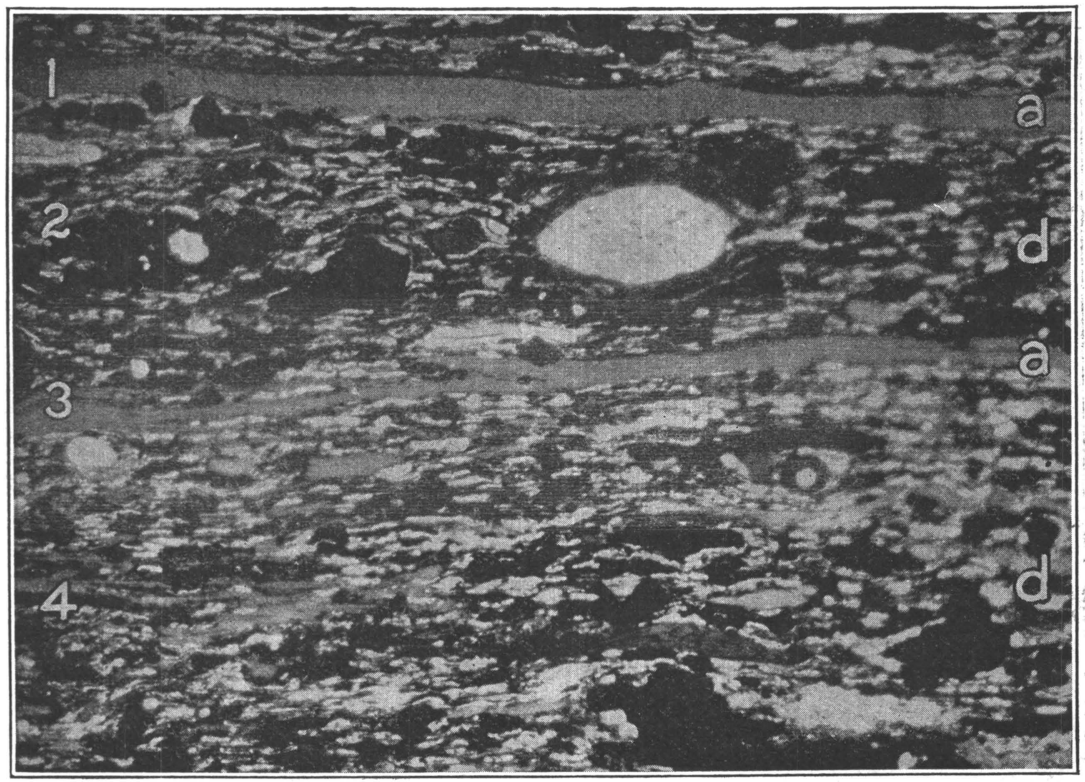

A. AREA FROM PLATE XLIV, $A$. (X 200)

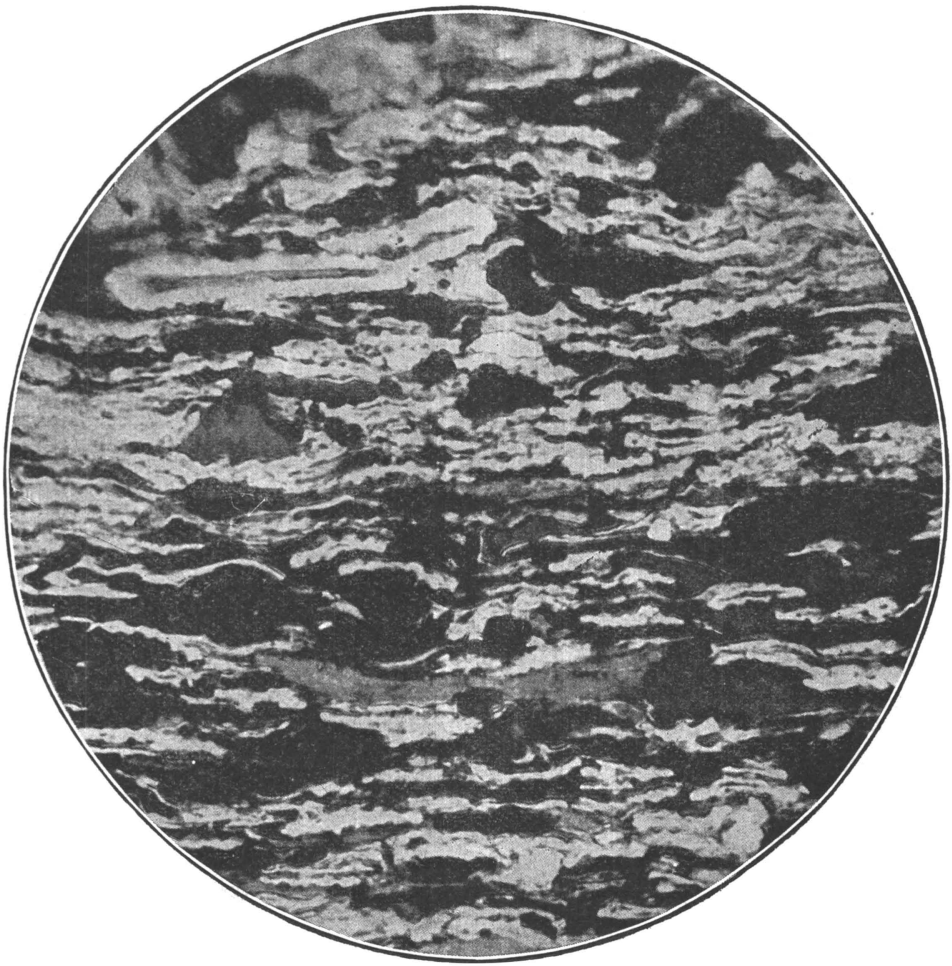

B. AREA FROM PLATE XLIV, $A$. (X 1000) 


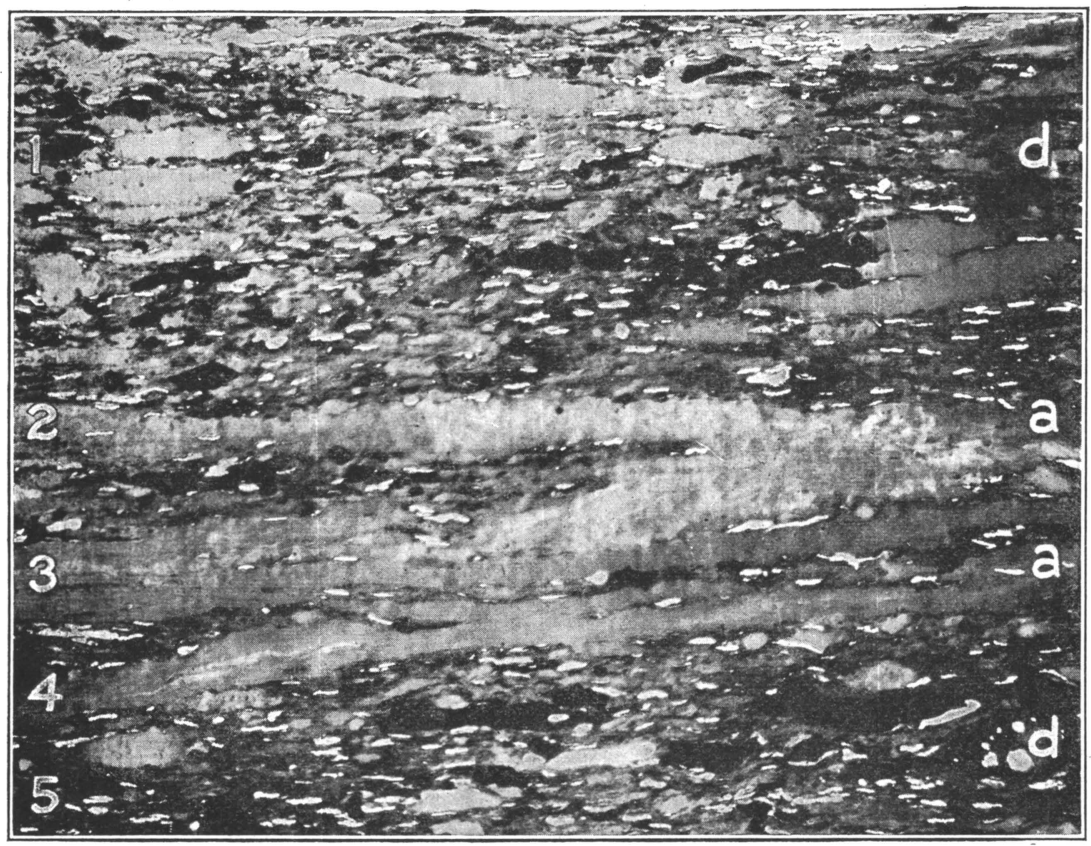

A. THIN VERTICAL SECTION OF COAL (X 200) FROM THE OAK MINE, SECOND FOOT.

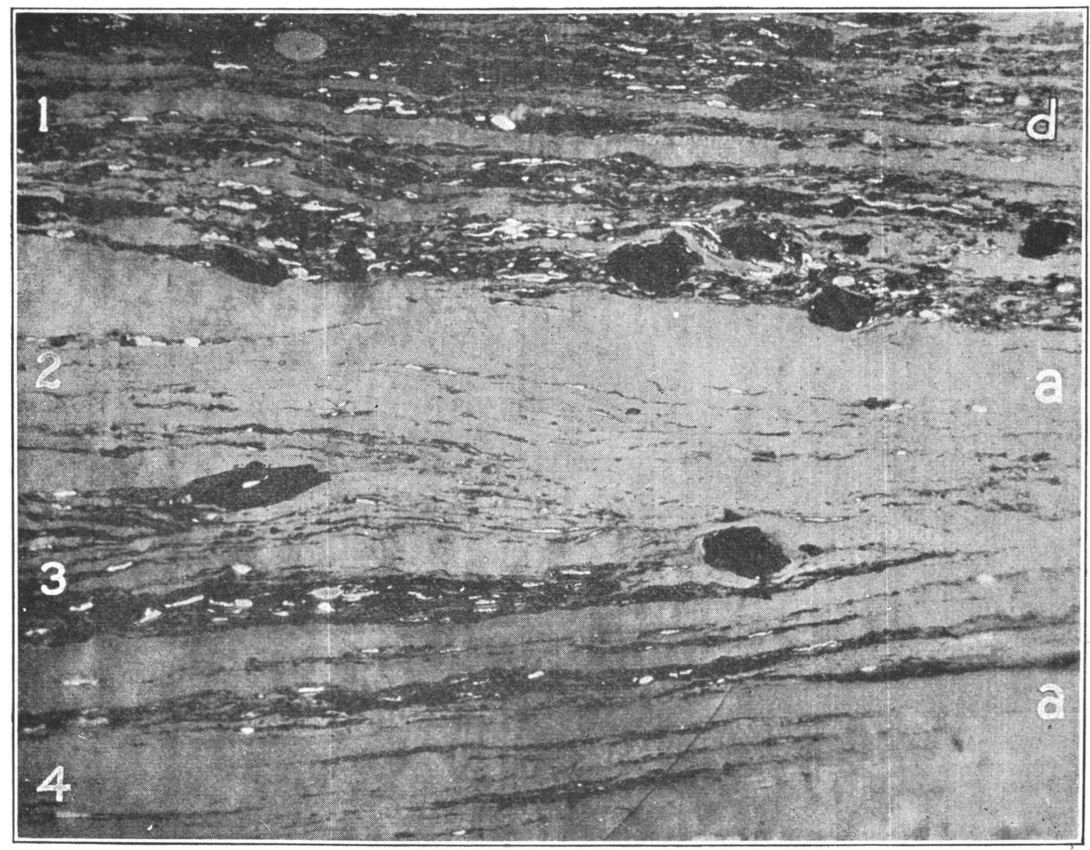

B. ANOTHER THIN SECTION OF COAL (X 200) FROM THE OAK MINE, SECOND 


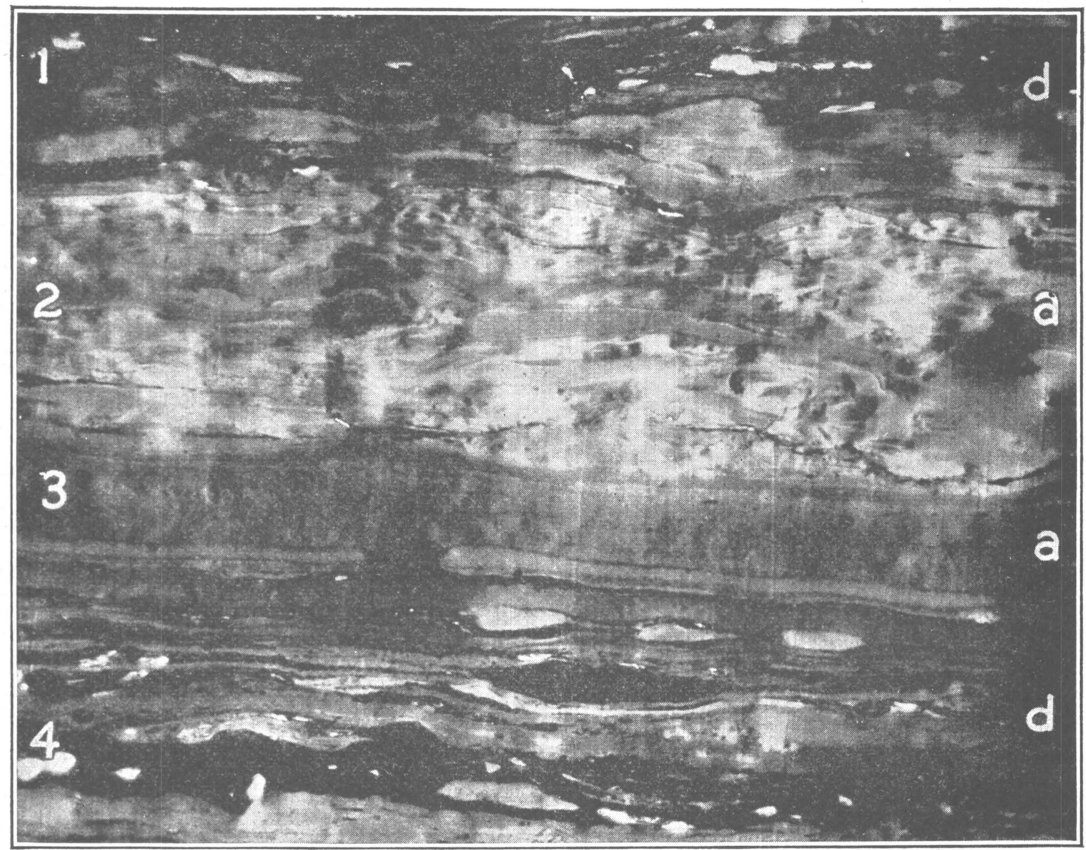

A. THIN VERTICAL SECTION OF COAL (X 200) FROM THE OAK MINE, THIRD FOOT.

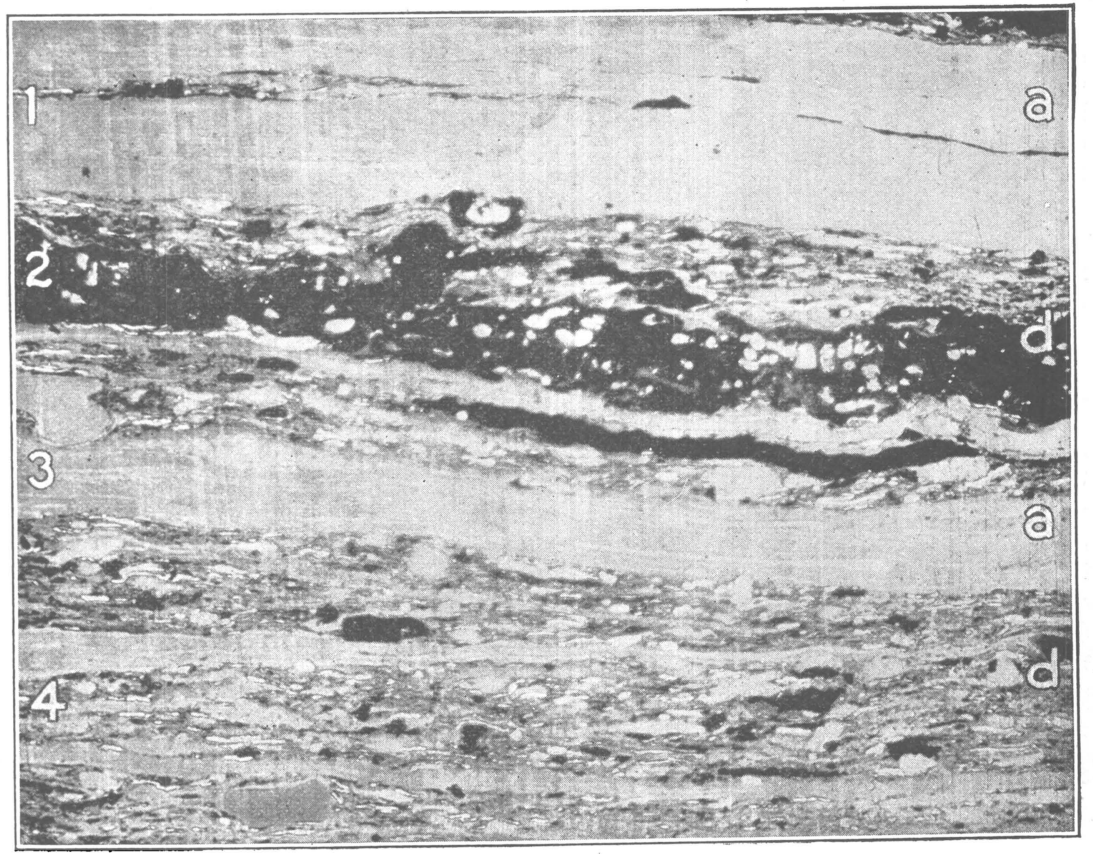

B. ANOTHER THIN SECTION FROM THE THIRD FOOT OF COAL, OAK MINE. (X 200) 


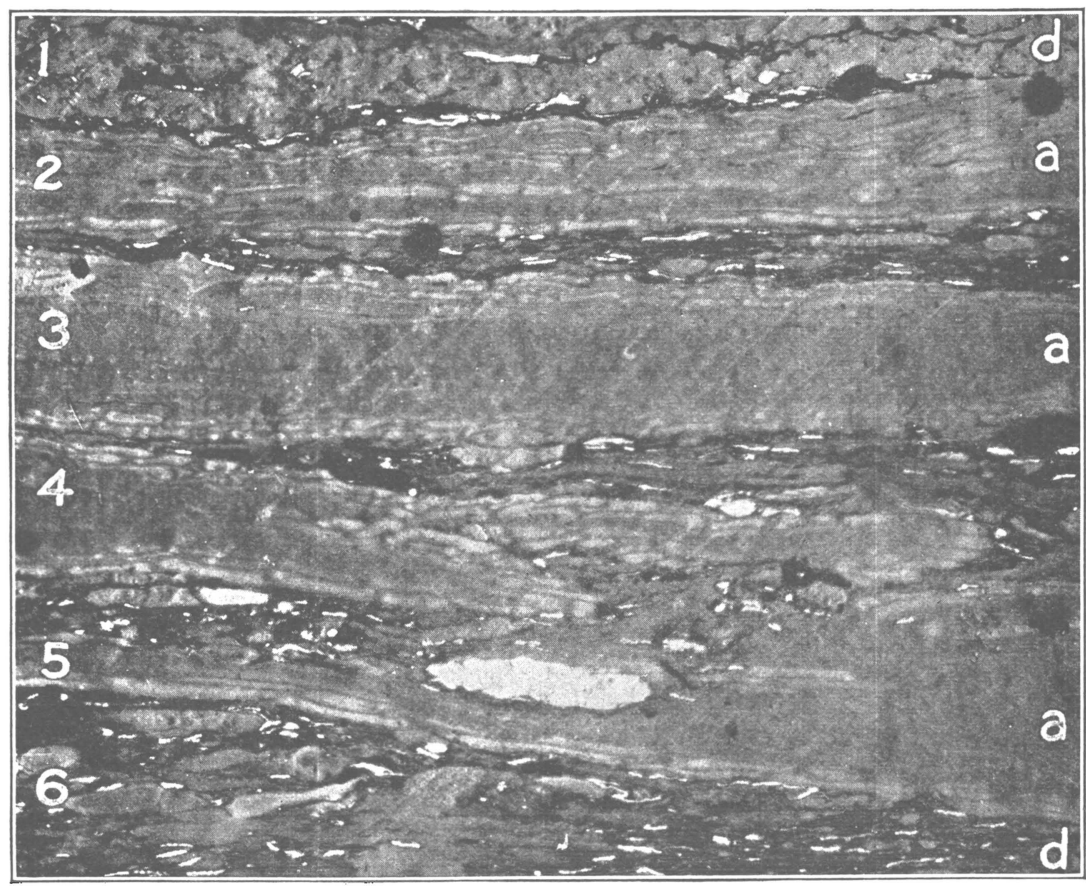

A. THIN VERTICAL SECTION OF COAL (X 200) FROM THE OAK MINE, FOURTH FOOT.

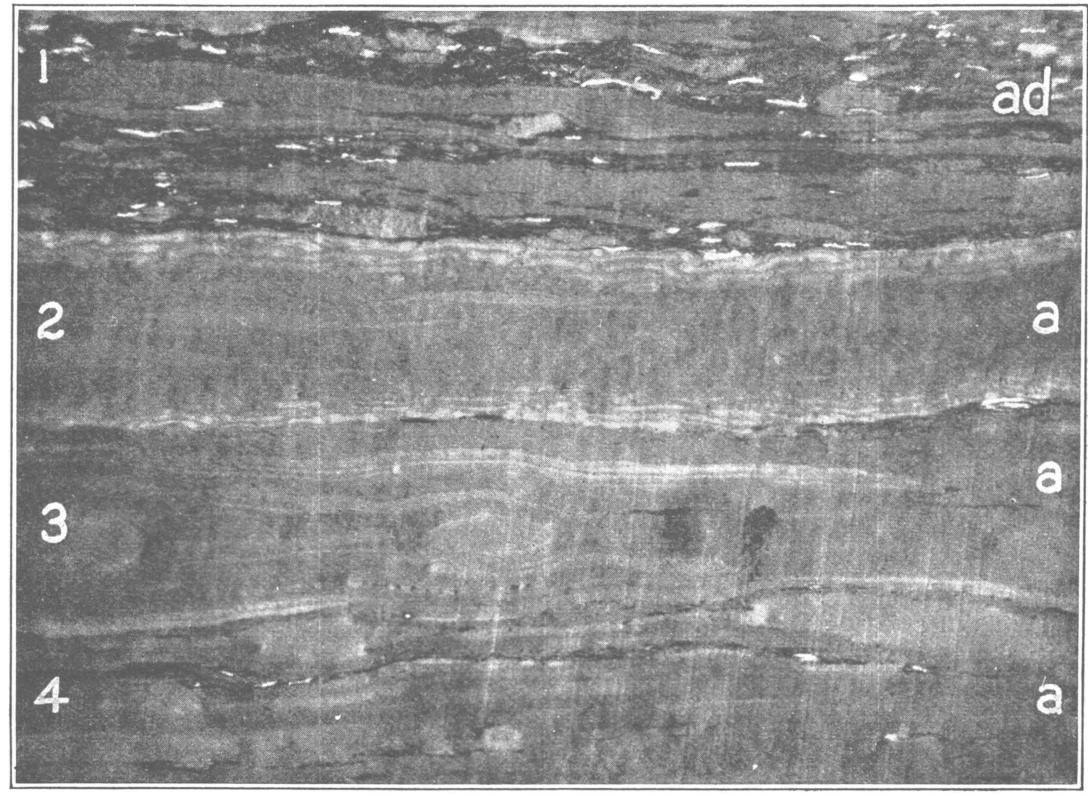

B. ANOTHER THIN SECTION OF FOURTH-FOOT COAL. OAK MINE. (X 200) 


\section{PLATE LVII.}

\section{THIN VERTICAL SECTIONS.}

A. A thin cross section $(\times 200)$ from the coal from the fourth foot from the woof of the Oak mine, showing a number of closely packed anthraxylon strips, the cell structure of which is clear.

B. A thin cross section $(\times 200)$ from the fourth foot from the roof of the Oak mine, showing a common condition of the coal at this level. The anthraxylon strips are closely packed. Cell structure is represented by the fine striation.

\section{PLATE LVIII.}

\section{THIN VERTICAL SECTIONS.}

A. A thin cross section $(\times 200)$ showing the coal from the first foot from the floor at the Oak mine. Disintegrated humic matter is seen at $1-d$ in the upper part and at $3-d$ in the lower part; at 2-a in the central part are fairly well preserved anthraxylon chips, in which the spiral thickenings are recognizable.

B. A thin cross section $(\times 200)$ of the fifth foot from the roof of the coal from the Oak mine, showing fairly well preserved woody structures. The structure at $2-a$ is due to spiral thickenings of the original structure.

\section{PLATE. LIX.}

\section{THIN VERTICAL SECTIONS.}

A. A thin cross section $(\times 200)$ of the fifth foot of coal from the roof of the Oak mine, showing a woody structure commonly in the Pittsburgh coal.

$B$. A thin cross section $(\times 200)$ of a thicker anthraxylon component, showing a structure common in the Pittsburgh coal, as well as in coals from other beds. The white lenticular to oval inclusions represent resinous matter always present in such tissues.

\section{PLATE LX.}

\section{MEGASPORANGIUM AND CHARCOAL IN THIN VERTICAL SECTIONS.}

A. A thin cross section, the second foot of coal, from the Oak mine, showing anthraxylon embedded in the attritus and a tissue, 2-sg, which is that of a young megasporangium including megaspores. The cell structure is well preserved in the tissue. Such structures are commonly found in this coal as well as in the other coals examined.

B. A thin cross section from the coal from the Oak mine, showing a bit of charcoal, characteristic of almost all coals, embedded in an attritus containing much finely divided carbonaceous matter. The appearance, origin, and mode of formation seem to be the same for all charcoal regardless of size. 


\section{PLATE LXI.}

\section{THIN HORIZONTAL SECTIONS.}

A. A thin horizontai section $(\times 150)$ of the first foot of coal from the Oak mine, showing the general appearance of the attritus in a horizontal section. The small circular to slightly oval areas are the spore-exines seen on their broad side, the irregular black areas are more highly carbonized matter or bits of charcoal, and the irregular gray areas are humic matter.

$B$. A more highly magnified portion of $A(\times 1,000)$, showing the constitvents in detail. The sculpturing of the spore-exines, which are gray, circular, and oval areas, is clearly seen. Note the carbonized and more opaque matter and its distribution in the humic matter.

\section{PLATE LXII.}

\section{THIN IIORIZONTAL SECTIONS.}

A. A thin horizontal section from the second foot of coal from the Oak mine $(\times 150)$, showing the general character of the coal in horizontal section. The larger part of the constituents is attritus; in the lower right-hand part is a horizontal section of an anthraxylon chip in which the cell structure is clear. The different constituents composing the attritus, such as spore-exines, humic matter, and carbonaceous matter, are distinguishable.

B. An area included in $A(\times 1,000)$, showing the constituents in detail. The oval bodies are the pollen-exines abundant in this coal. A few spore-exines are shown indistinctly; the carbonaceous matter is represented by definite particles greatly varying in size; the humic matter is in gray.

\section{PLATE LXIII.}

THIN VERTICAL SECTION.

Thin cross section of the Pittsburgh coal from the Experimental mine $(\times 200)$, continued in Plates LXIV, LXV, and LXVI. The anthraxylon strips at 2-a, 3-a, 5-a, 7-a, and 9-a are distinctly separated from one another by the layers of attritus, $1-\mathrm{l}, 4-\mathrm{l}, 6-\mathrm{d}, 8-\mathrm{d}$, and $10-\mathrm{l}$. The attritus is composed largely of humic matter in the form of particles or granules of greatly varying sizes; spore-exines are relatively few, and the proportion of carbonaceous matter is small.

\section{PLATE LXIV.}

\section{CONTINUED FROM PLATE LXIII.}

The anthraxylon strips, of which there are a number, are not definitely separated by attritus here, but are packed rather closely. The cell structure is distinguishable everywhere. 


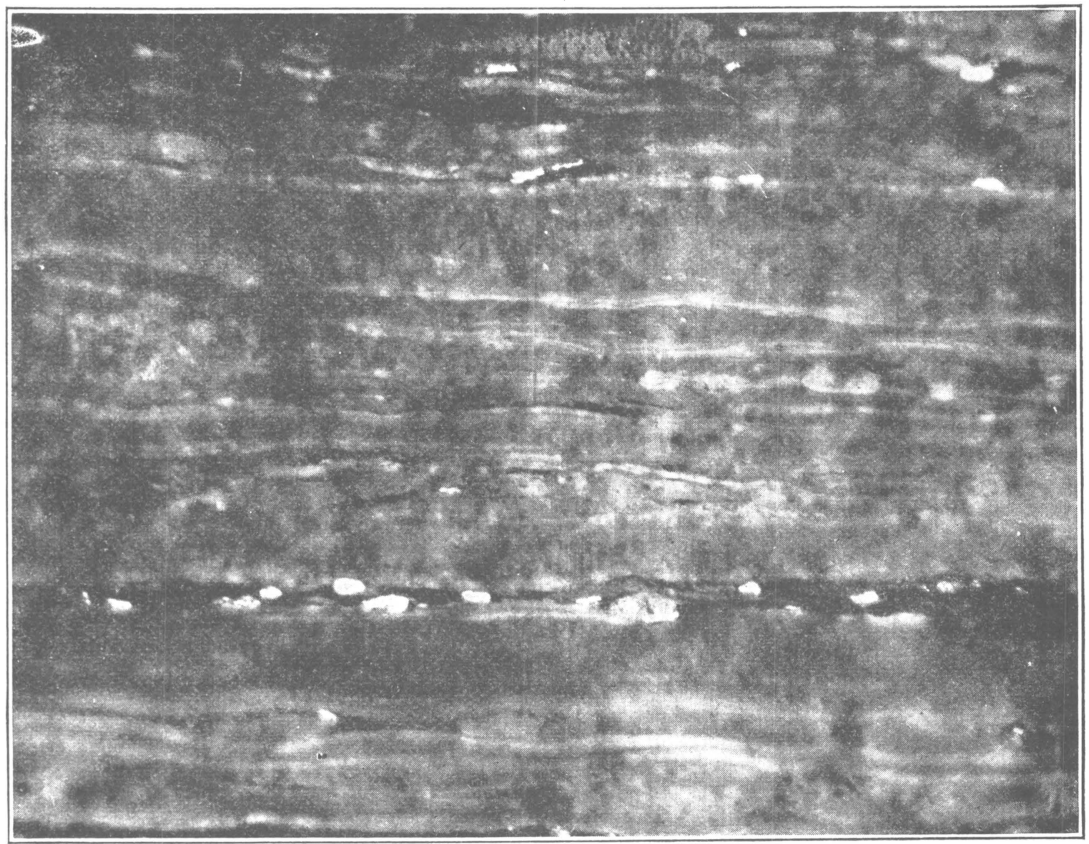

A. A THIN SECTION OF THE SAME COAL SHOWN IN PLATE LVI, SHOWING CELL STRUCTURE OF ANTHRAXYLON STRIPS. (X 200)

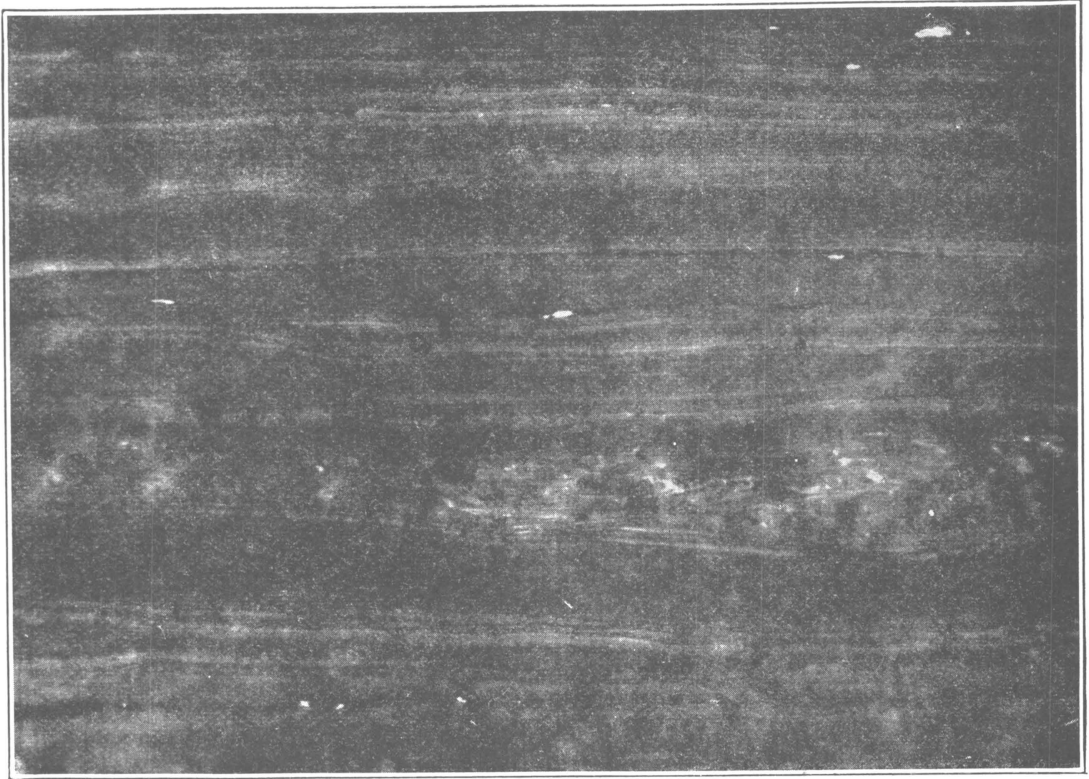

B. A THIN SECTION OF THE SAME COAL SHOWN IN PLATE LVI, SHOWING CLOSELY PACKED ANTHRAXYLON STRIPS. (X 200) 


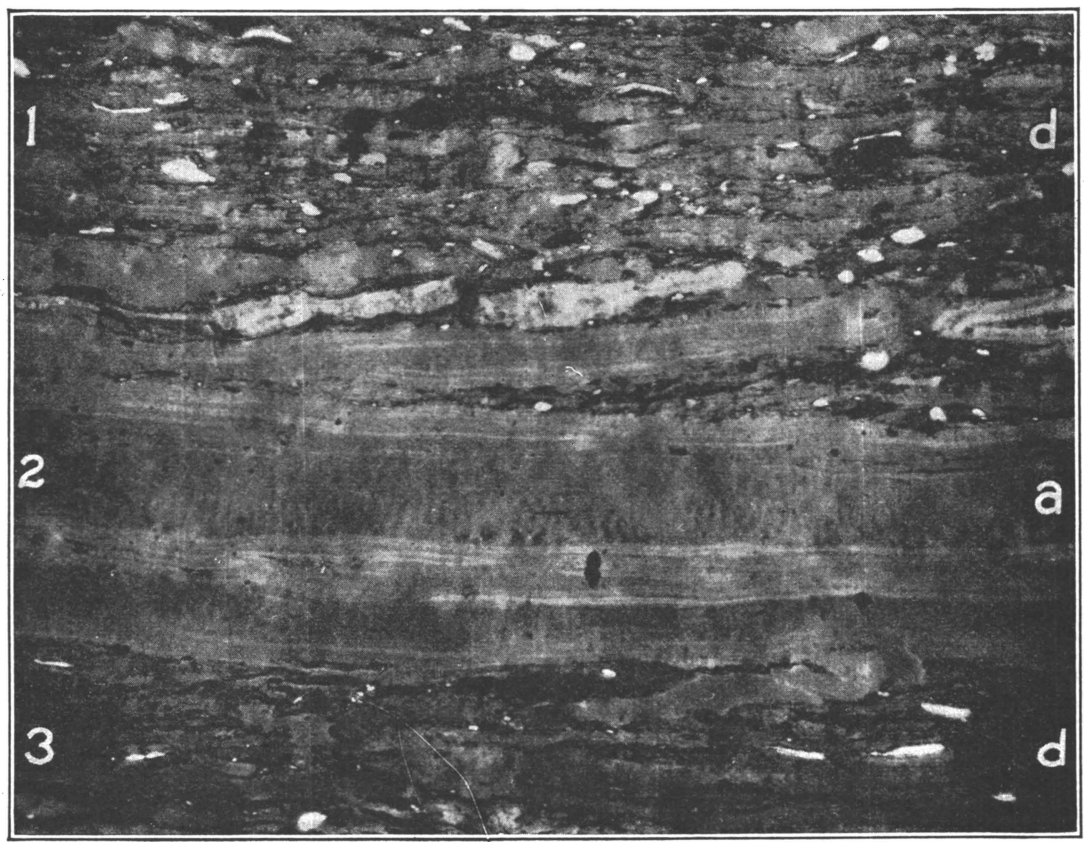

A. THIN VERTICAL SECTION OF COAL FROM THE OAK MINE, FIFTH FOOT. (X 200)

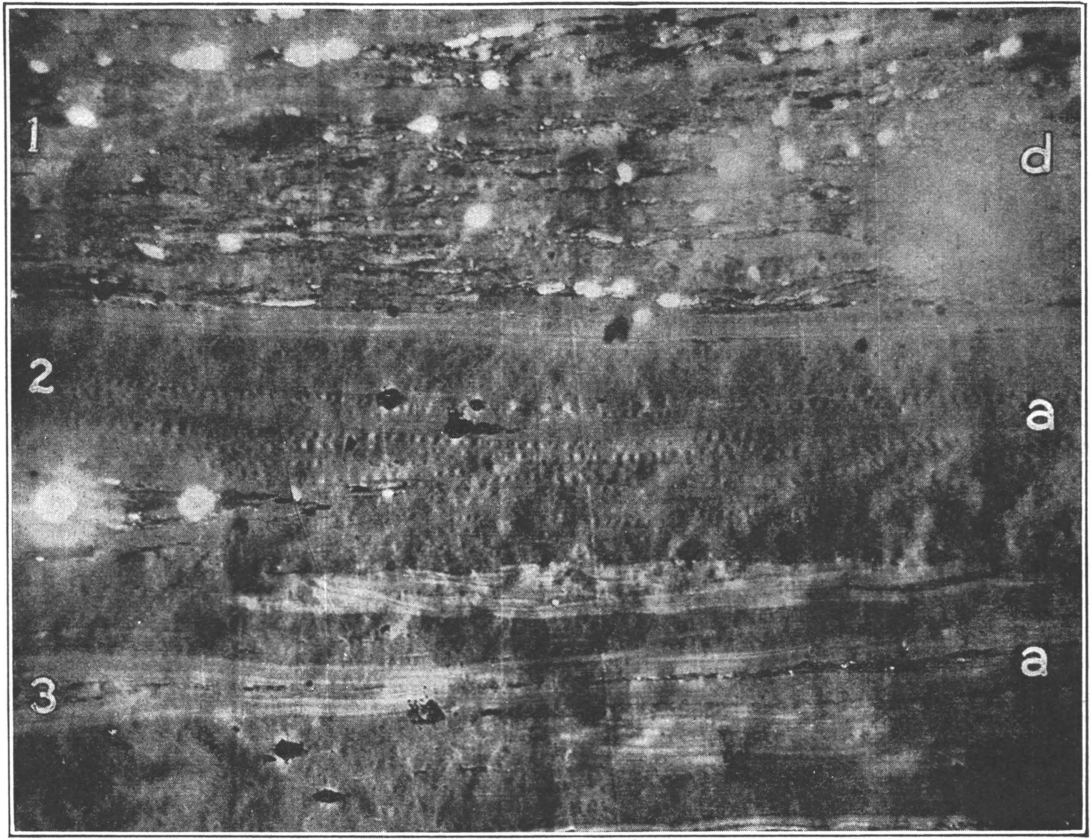

B. ANOTHER SECTION FROM THE FIFTH FOOT OF COAL, OAK MINE. (X 200). 


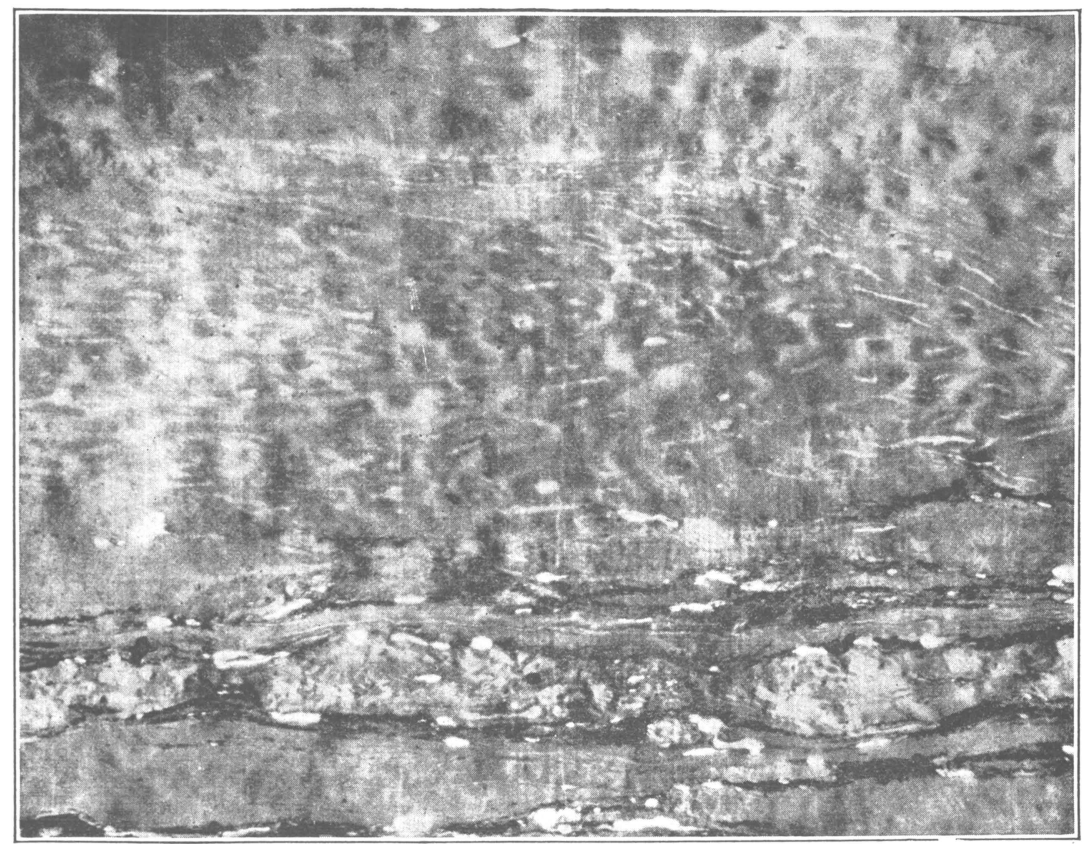

A. A THIN SECTION FROM THE SAME FOOT OF COAL AS THAT SHOWN IN PLATE LVIII. (X 200)

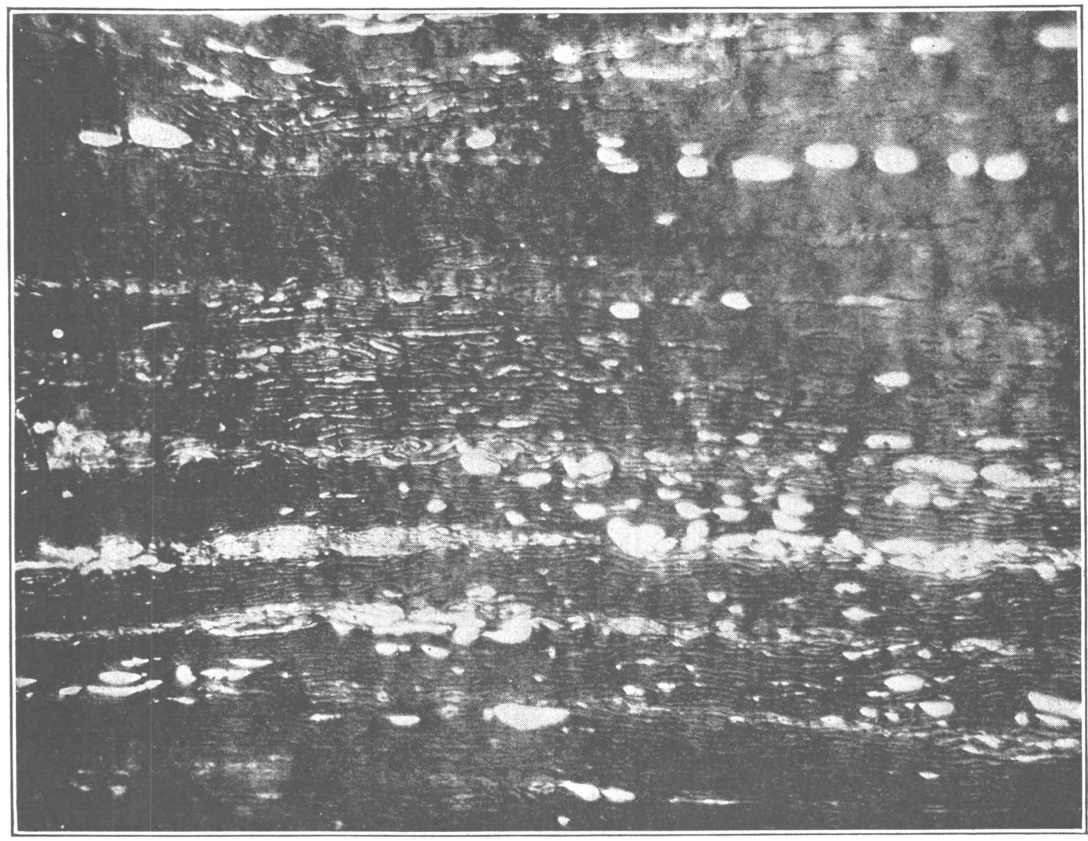

B. THIN SECTION OF ANTHRAXYLON WITH RESINOUS INCLUSIONS. (X 200) 


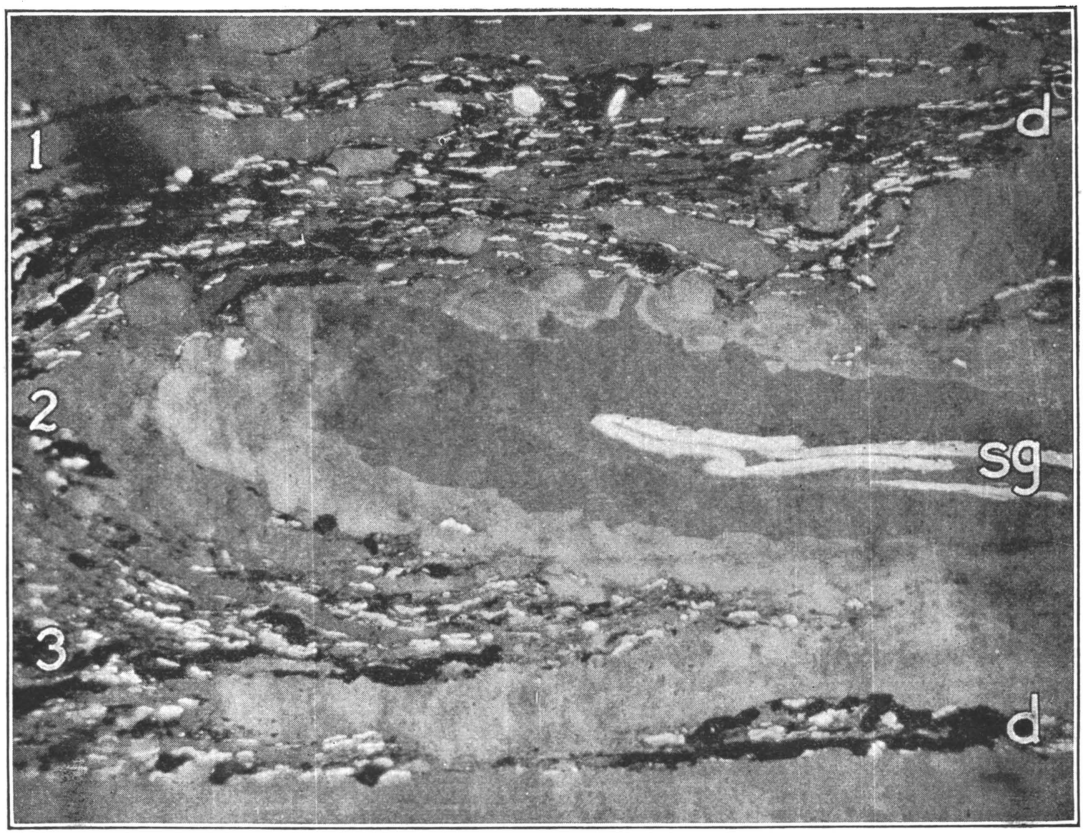

A. MEGASPORANGIUM IN COAL FROM THE OAK MINE. (X 200)

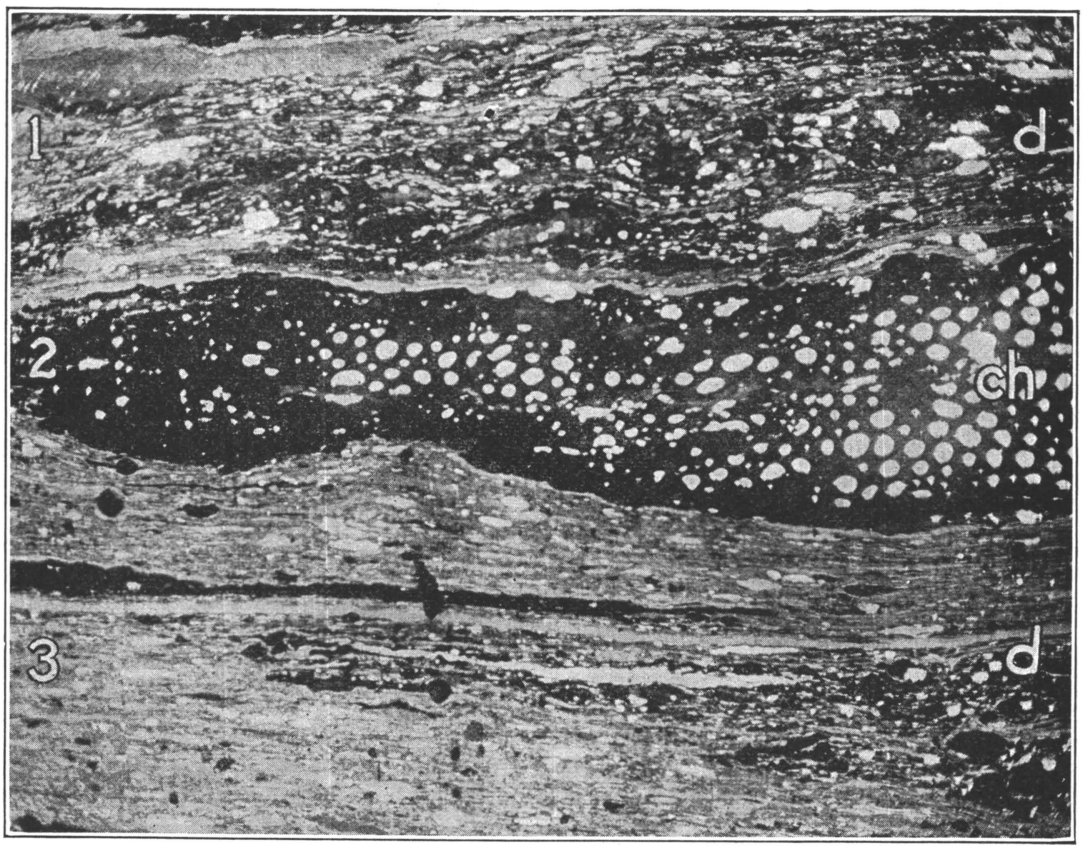

B. CHARCOAL IN COAL FROM THE OAK MINE. (X200) 


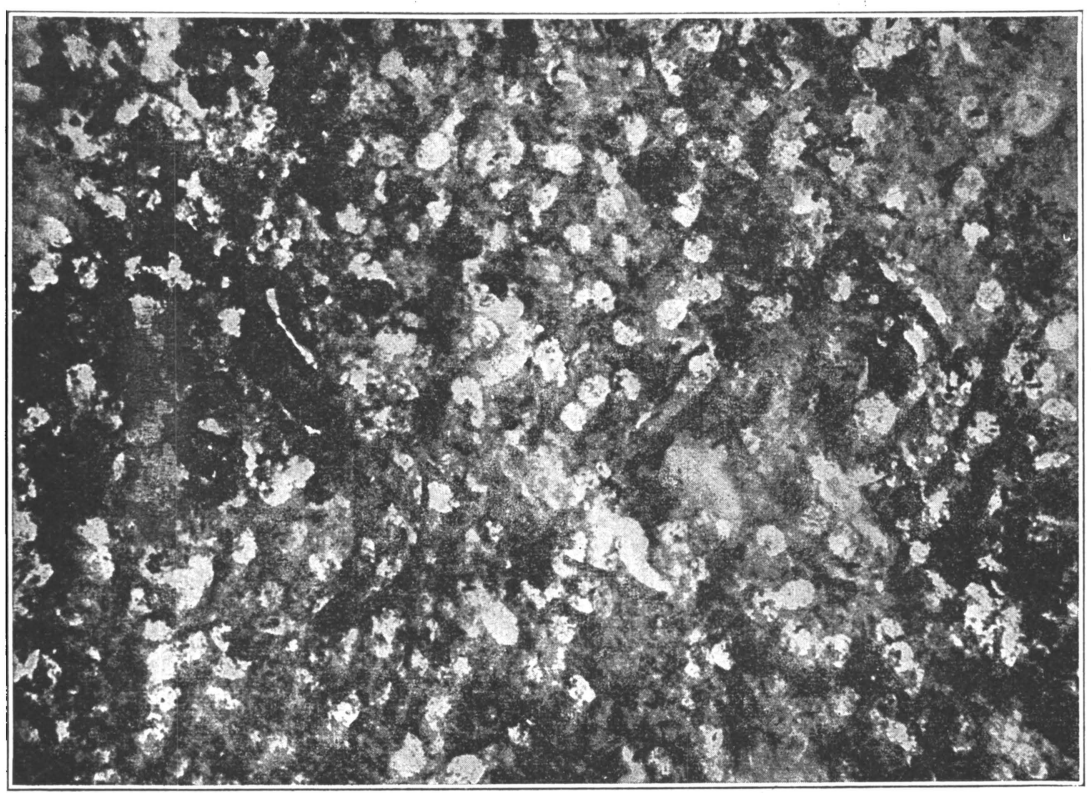

A. THIN HORIZONTAL SECTION OF COAL FROM THE OAK MINE, FIRST FOOT. (X 150)

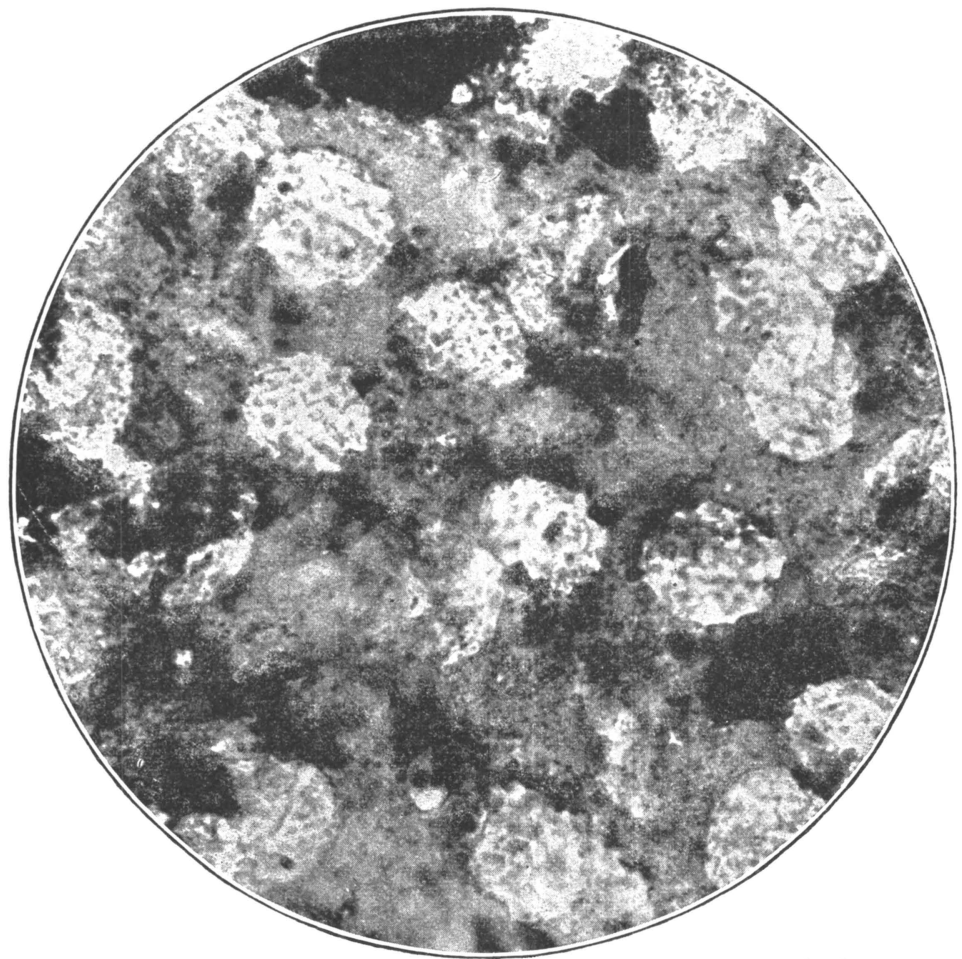

B. HIGHLY MAGNIFIED AREA FROM THE SECTION ABOVE. (X 1000) 


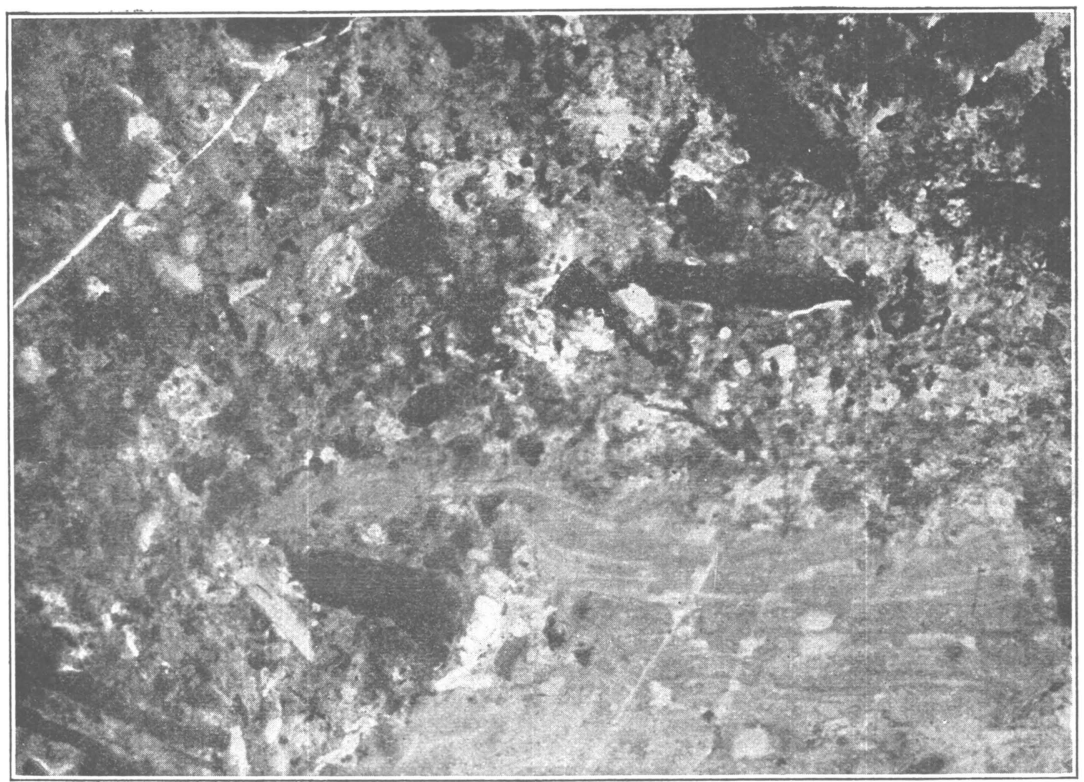

A. THIN HORIZONTAL SECTION OF COAL FROM THE OAK MINE, SECOND FOOT. (X 150)

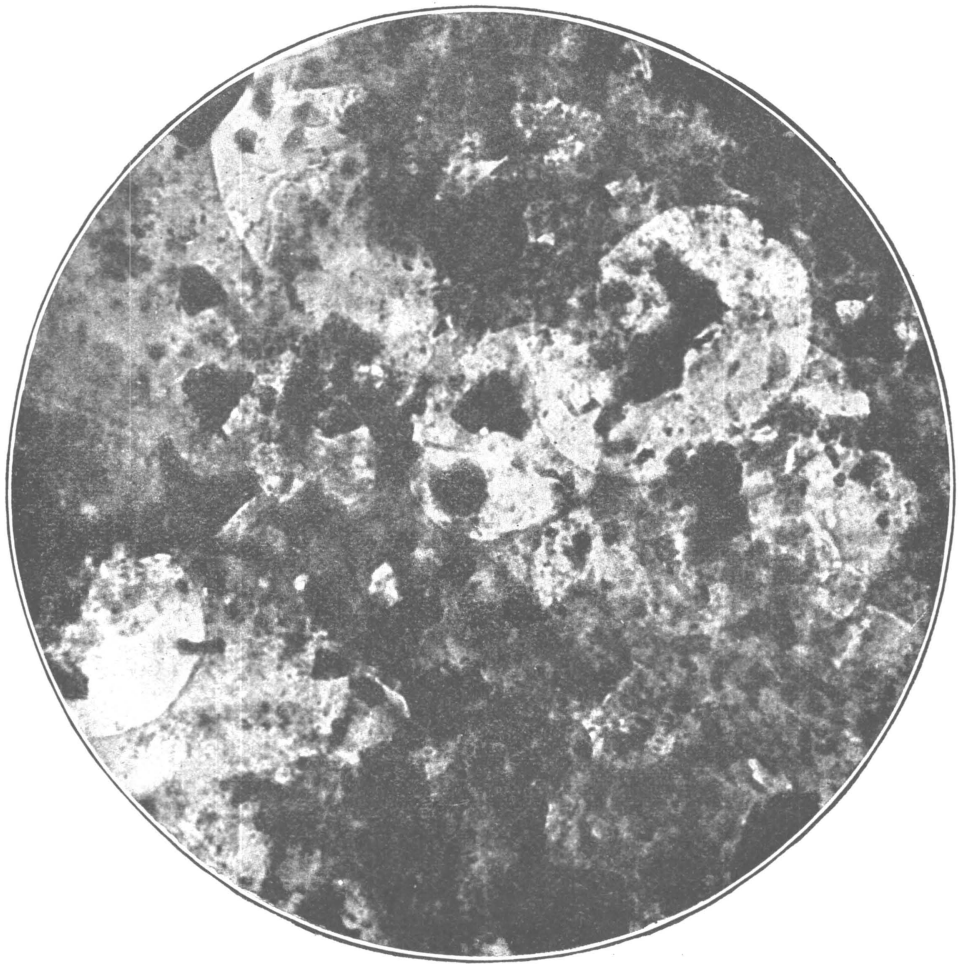

B. AREA FROM SECTION SHOWN ABOVE, HIGHLY MAGNIFIED. (X 1000) 


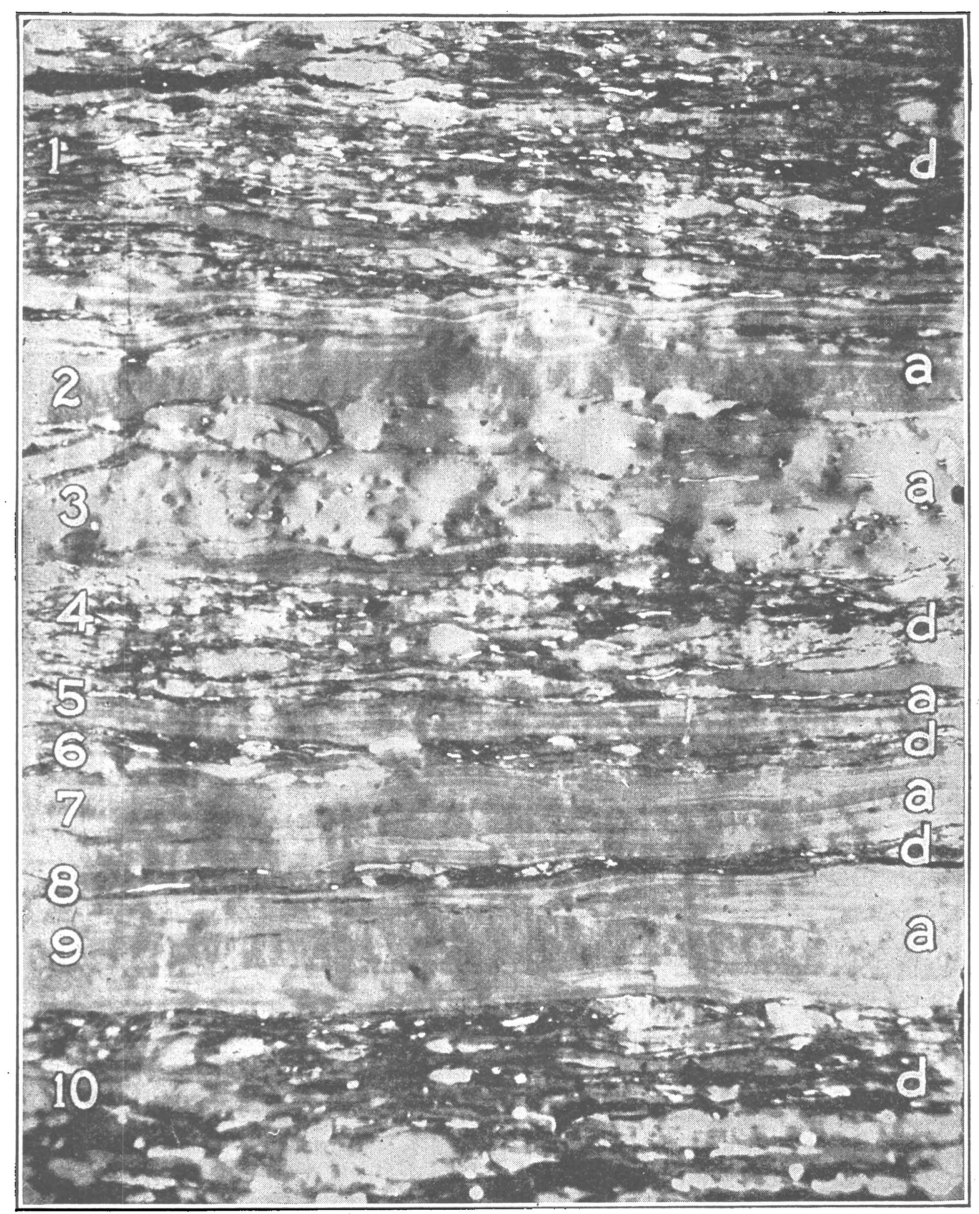

THIN VERTICAL SECTION OF COAL FROM THE EXPERIMENTAL MINE. (X 200) 


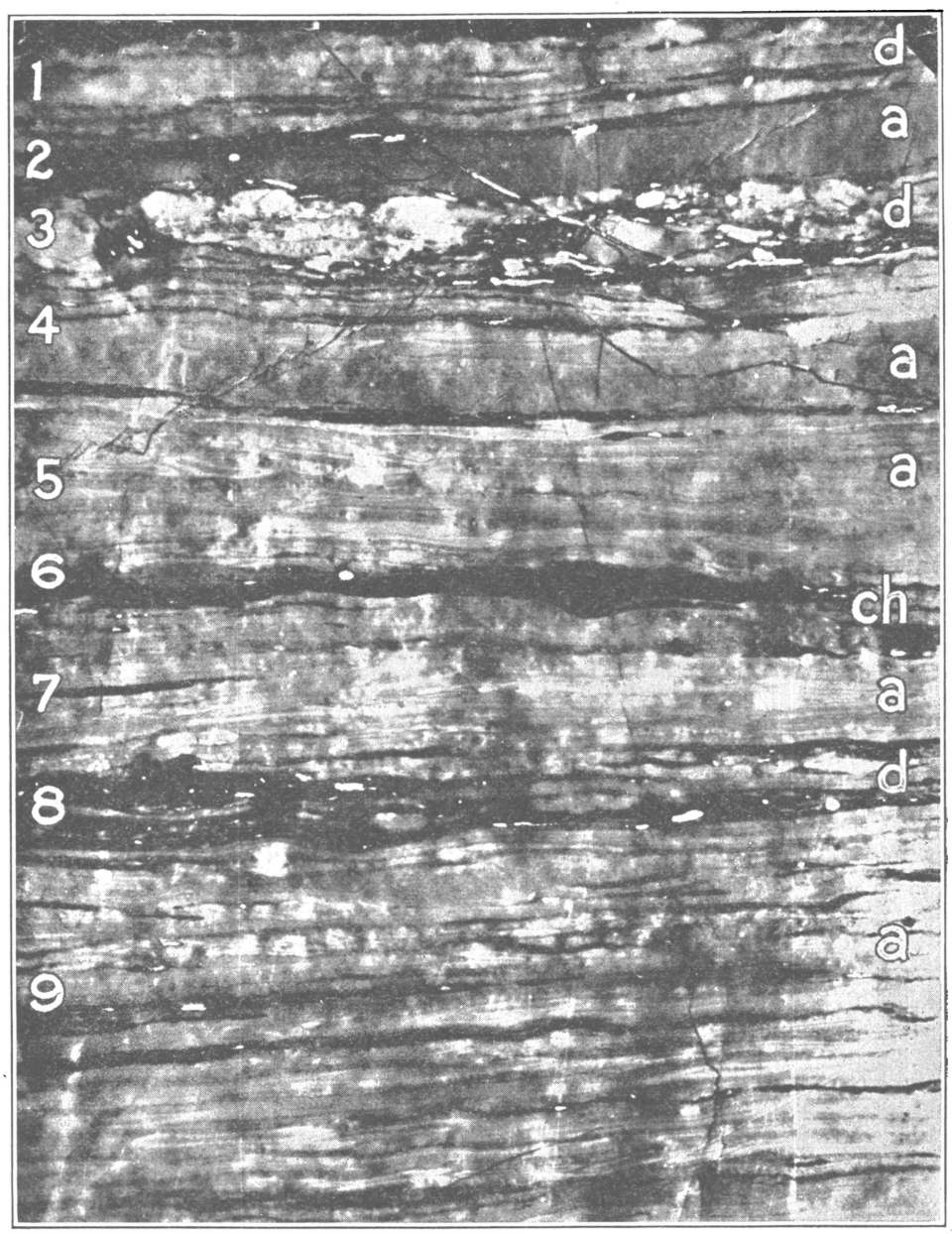




\section{PLATE LXV.}

\section{CONTINUED FROM PLATE LXIV.}

The anthraxylon matter is here much disintegrated. There is no definite line of distinction between the anthraxylon chips and the humic matter in the finely divided state in which it forms a constituent of the attritus. Evidences of cell structure are seen in even the small particles.

\section{PLATE LXVI.}

CONTINUED FROM PLATE LXV.

This photograph shows a considerable amount of more highly carbonized matter; the anthraxylon matter is much disintegrated. Spore-exines are relatively few.

\section{PLATE LXVII.}

\section{THIN VERTICAL SECTION.}

A thin cross section from the coal from the Experimental mine $(\times 200)$, showing an attritus rich in spore-exines, in which are embedded thin chips of anthraxylon, 2-a, 4-a, 6-a, and 8-a. A few particles of a more highly carbonized matter are shown.

\section{PLATE LXVIII.}

\section{THIN VERTICAL SECTION.}

A thin cross section $(\times 200)$ of coal from the Experimental mine, showing a layer with much comminuted anthraxylon. The bark-like tissue at $2-a$, in which the cell structure is well preserved, is common in some sections. It is dark brown, has a gummy appearance and irregular shapes. Although it is dark, its appearance differs altogether from that of the fragments of charcoal. 


\section{PLATE LXIX.}

\section{THIN VERTICAL SECTIONS.}

A. A thin cross section of coal from the Experimental mine $(\times 200)$ showing a strip of anthraxylon, 2-a, in which the cell structure is remarkably well preserved. The attritus at $3-d$ is very carbonaceous; the inclusion, shown in white, is a nest of intimately united spore-exines.

$B$. A thin cross section from the Pittsburgh coal at the experimental mine $(\times 200)$, showing a typical appearance of the attritus in this coal, rich in humic matter and including a large number of spore-exines. The black ovoid area at 4-d represents one of the many highly carbonized, resinous globules in the coal.

\section{PLATE LXX.}

\section{THIN VERTICAL SECTIONS.}

A. A part of the section shown in Plate LXIX, $B(\times 1,000)$, showing the distribution and nature of the components in detail. Spore-exines are represented by the linear white patches with a crenulated outline due to the sculpturing of the exine; the carbonaceous matter is in black and the humic matter in gray.

$B$. Another area included in the part of the cross section shown in Plate LXIX, $B(\times 1,000)$, showing a larger amount of carbonaceous matter and a number of resinous particles in the attritus.

\section{PLATE LXXI.}

\section{THIN HORIZONTAL SECTIONS.}

A. A thin horizontal section of the coal from the Experimental mine ( $\times 150)$ shows the general appearance of a horizontal section through a layer of comminuted humic matter. Toward the right the section cuts off horizontally a thin slice of an anthraxylon chip. The large proportion of cell structures is noticeable.

B. A thin horizontal section of the coal from the Experimental mine $(\times 150)$ cut through humic attritus.

\section{PLATE LXXII.}

\section{THIN HORIZONTAL SECTIONS.}

A. A thin horizontal section of coal from the Pittsburgh seam at the Experimental mine $(\times 150)$, showing a section cut horizontally through a vascular strand embedded in the attritus. Remnants of the spiral vessels are recognizable in the center of the strand.

$B$. A thin horizontal section from the Pittsburgh coal at the Experimental mine $(\times 150)$, showing a section through two overlapping anthraxylon chips; the cell structure, some of which is spiral, is clearly shown. Between the two chips is a vascular strand also showing spiral vessels. 


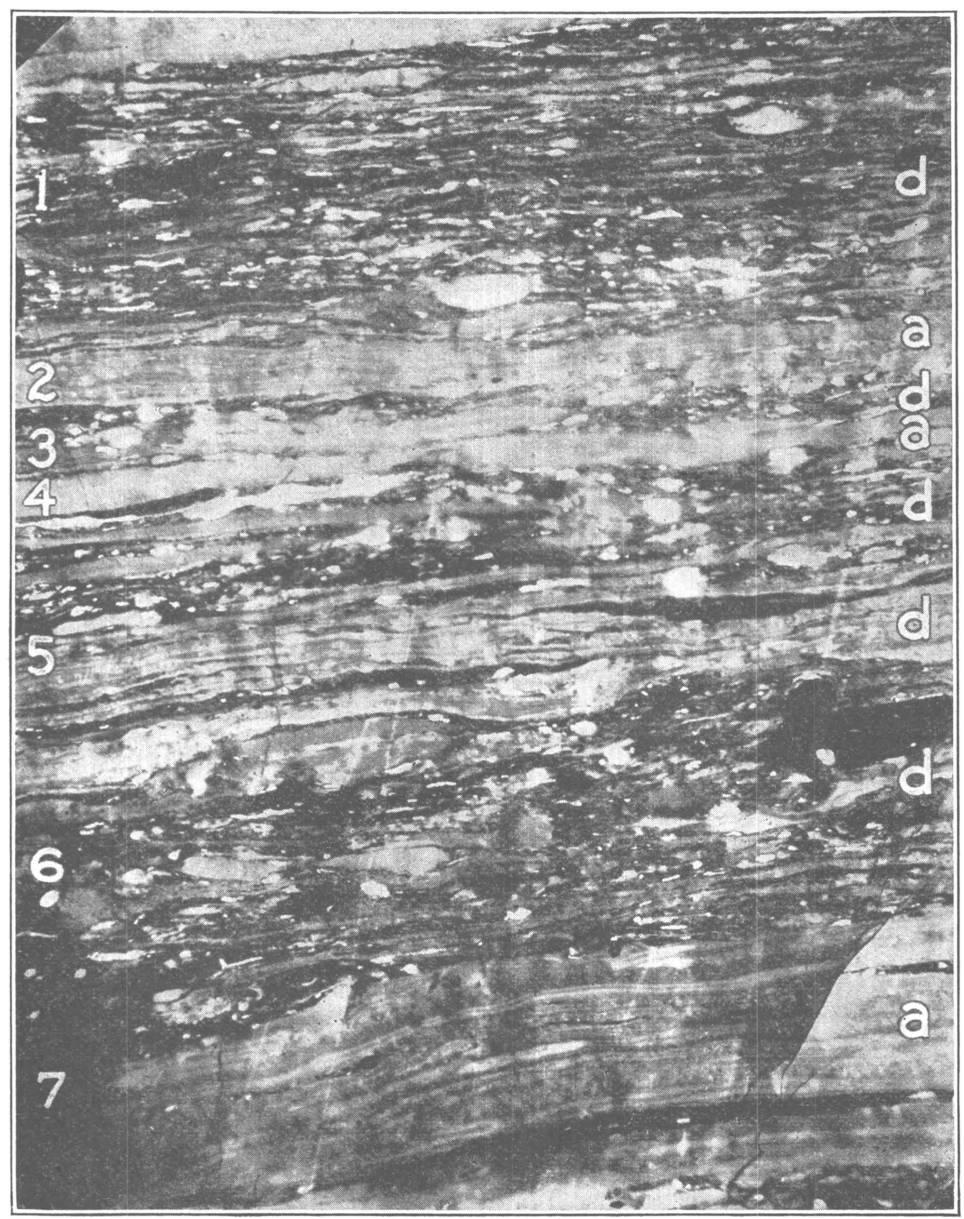

CONTINUATION FROM PLATE LXIV, (X 200) 


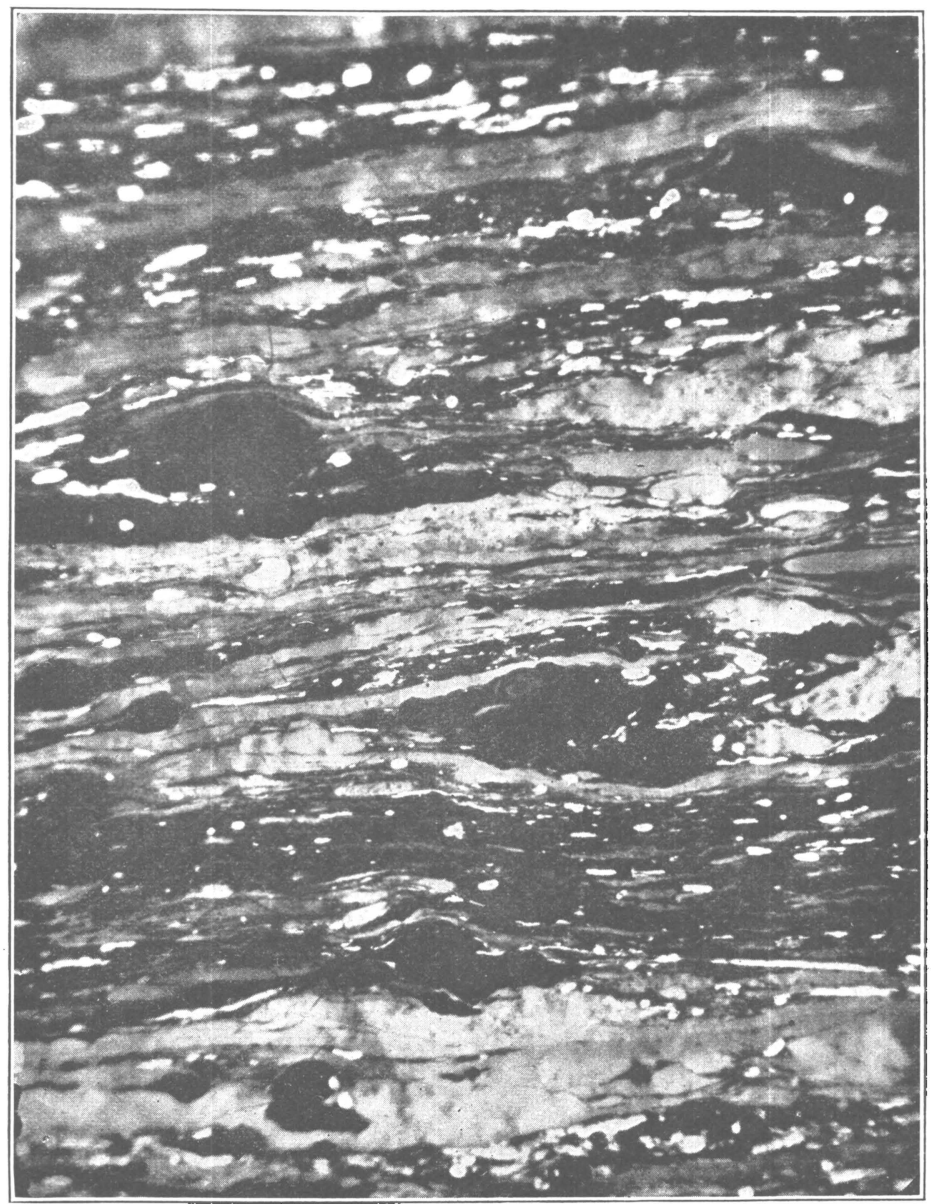

CONTINUATION FROM PLATE LXV. (X 200) 


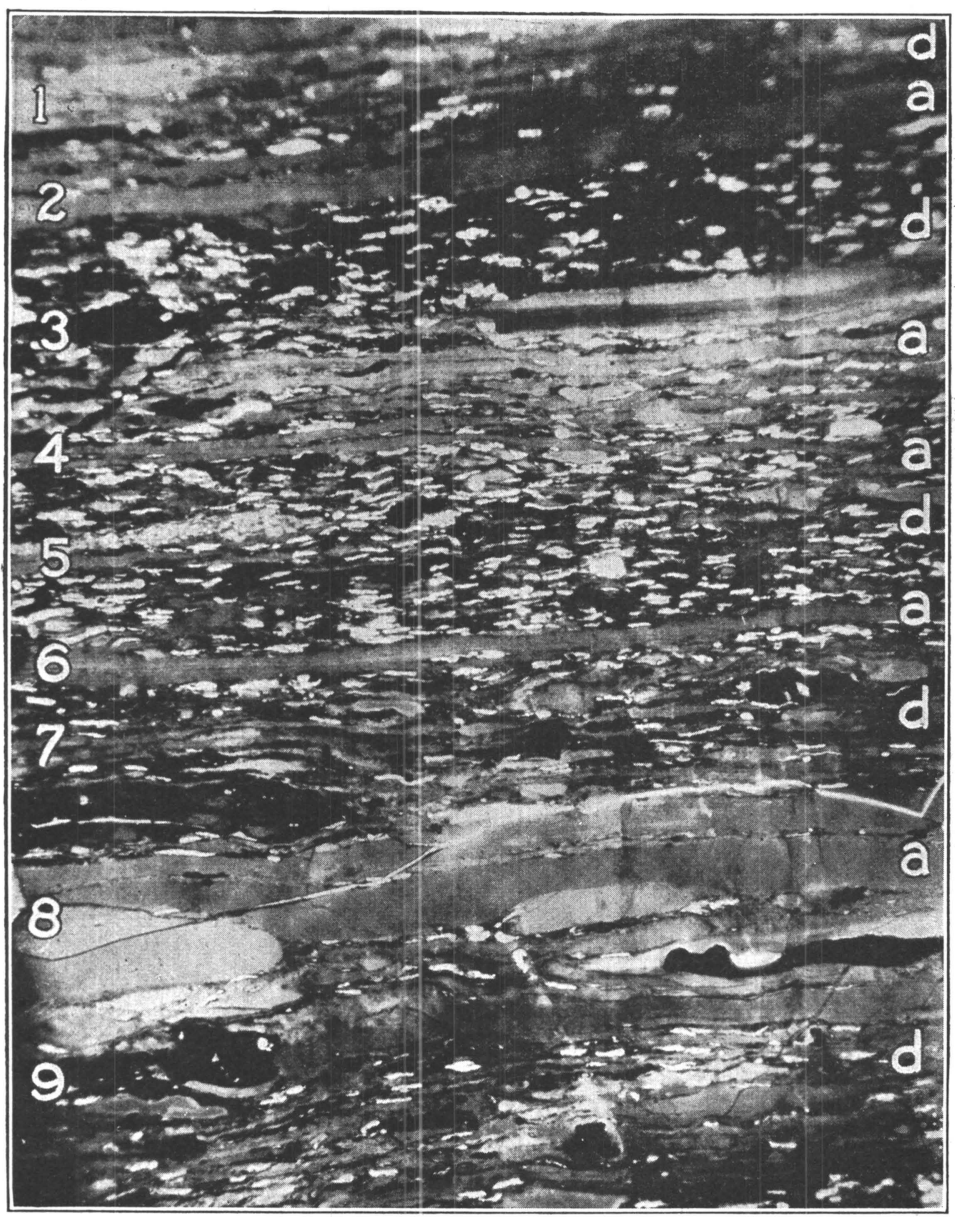

THIN VERTICAL SECTION OF COAL FROM EXPERIMENTAL MINE, SHOWS SPORE-EXINES, ANTHRAXYLON CHIPS, AND MORE HIGHLY CARBONIZED MATTER. (X 200) 


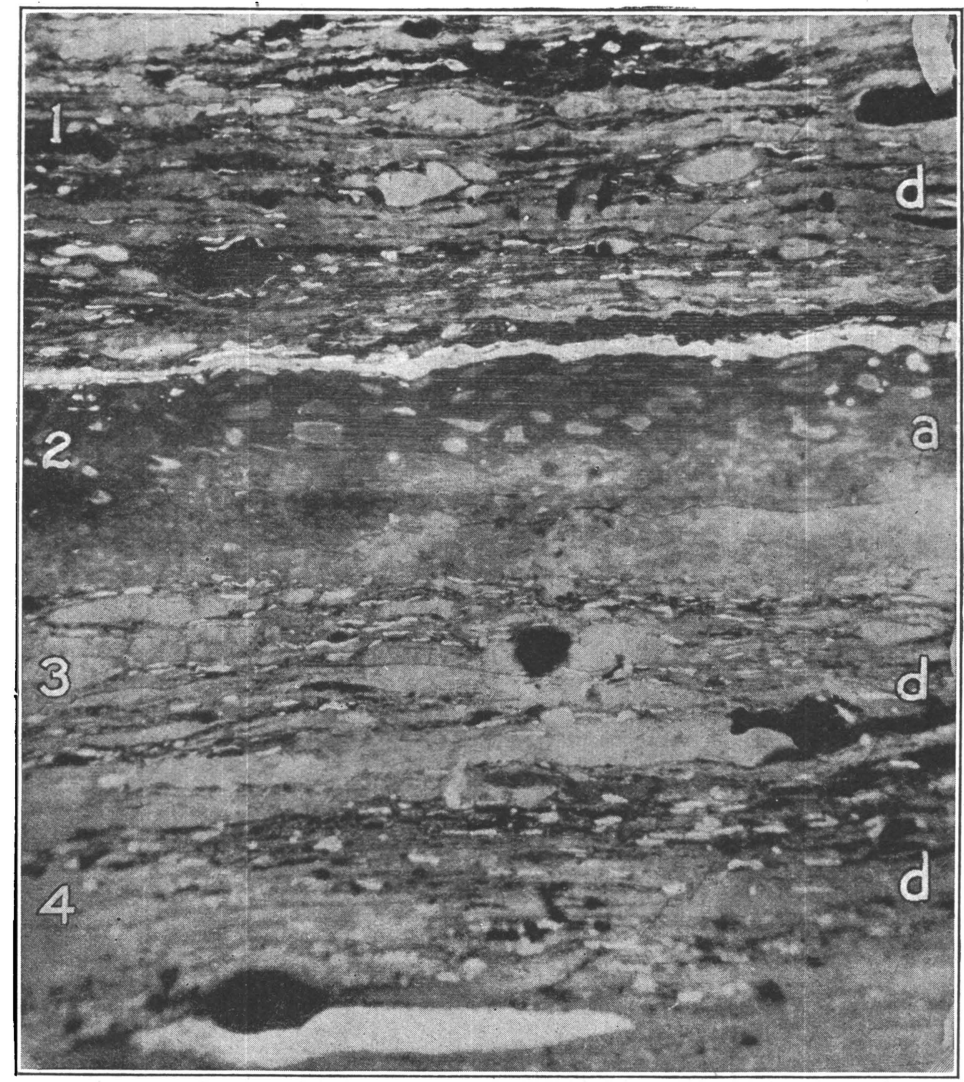

THIN VERTICAL SECTION OF COAL FROM EXPERIMENTAL MINE, SHOWS MACERATED ANTHRAXYLON AND WELL PRESERVED BARK TISSUE. (X200) 


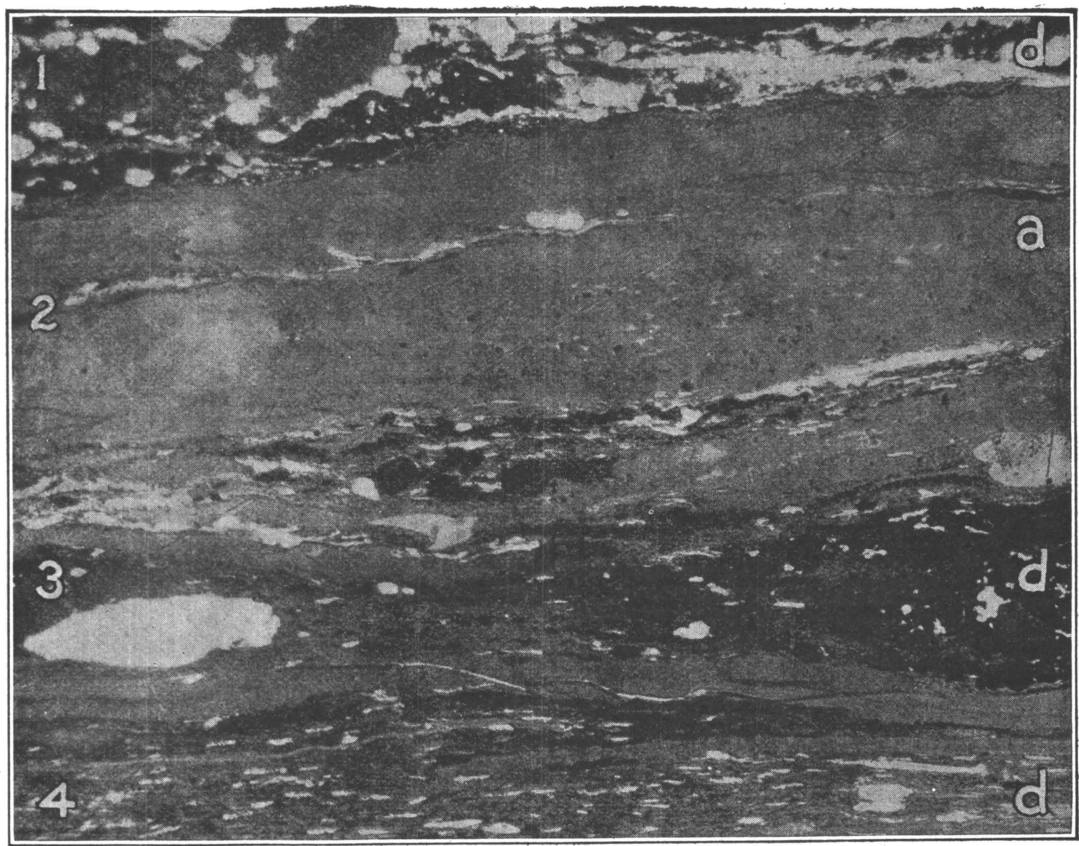

A. THIN VERTICAL SECTION OF COAL FROM THE EXPERIMENTAL MINE, SHOWING STRIP OF ANTHRAXYLON. (X 200)

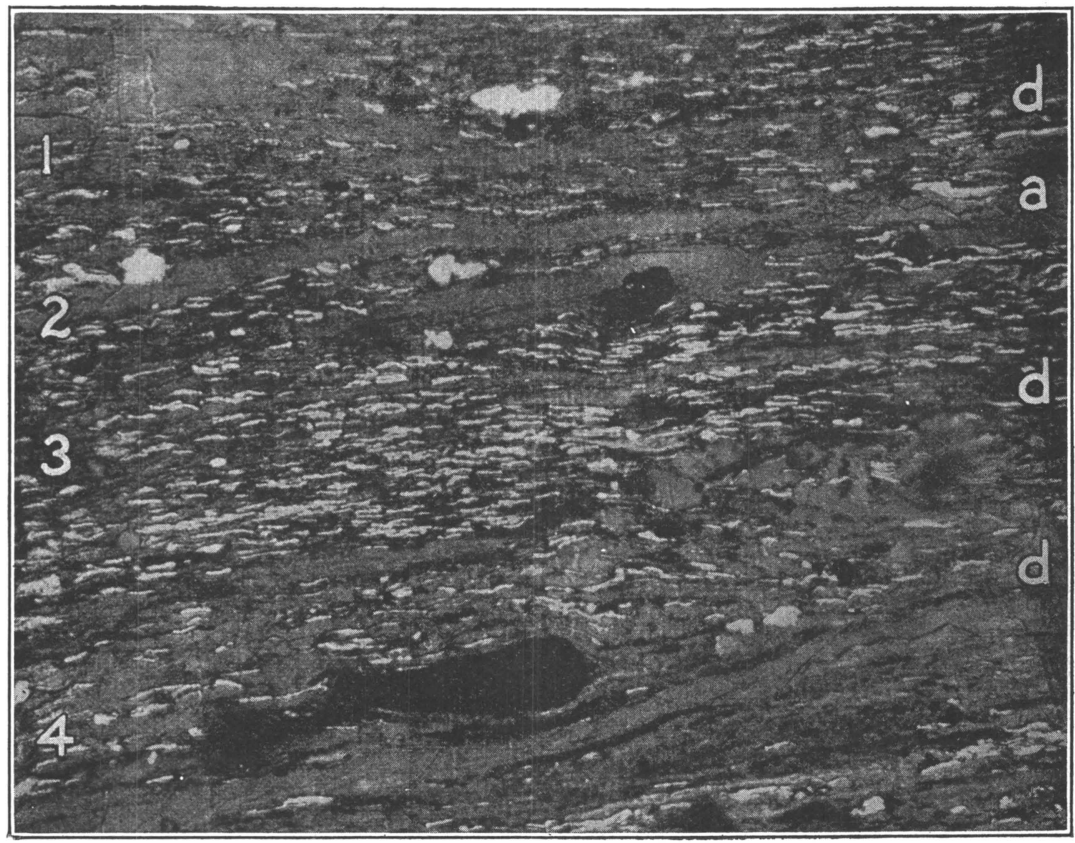

B. THIN VERTICAL SECTION OF COAL FROM THE EXPERIMENTAL MINE, SHOWS TYPICAL APPEARANCE OF ATTRITUS, (X 200) 


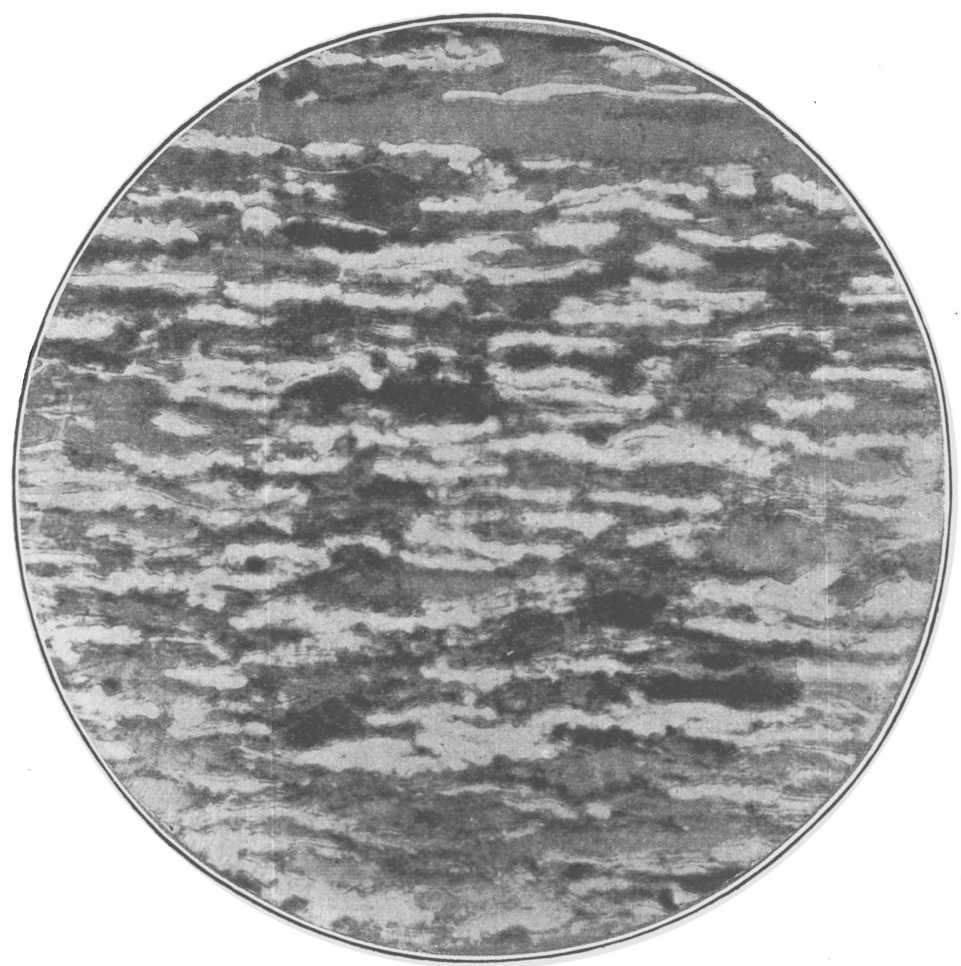

A. AREA FROM SECTION SHOWN IN PLATE LXIX, B. (X 1000)

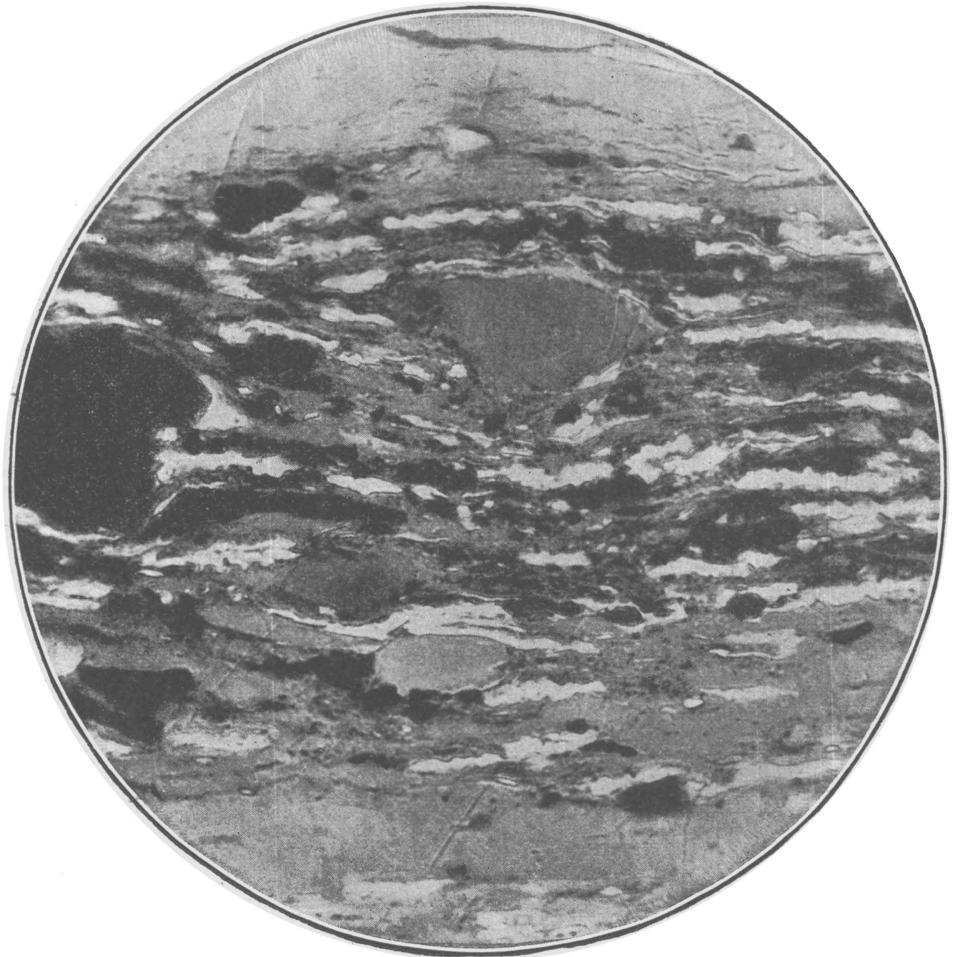

B. ANOTHER AREA FROM SECTION SHOWN IN PLATE LXIX, $B$. 


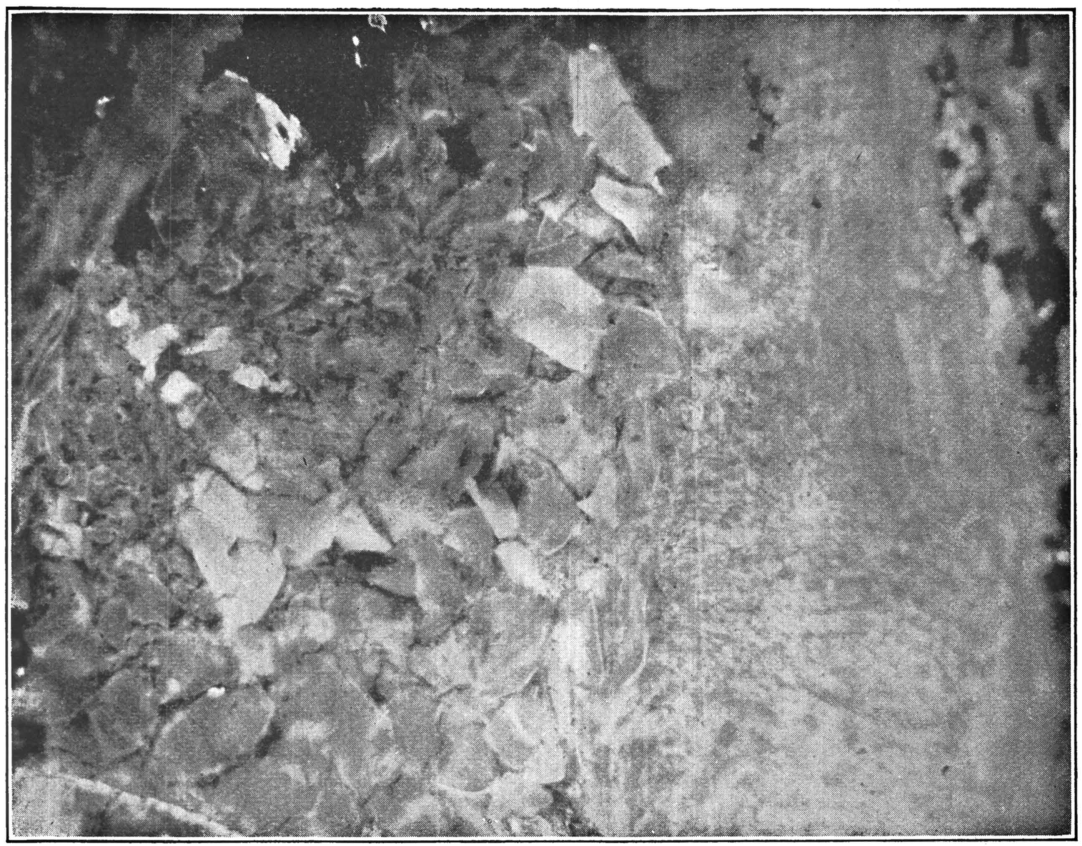

A. THIN HORIZONTAL SECTION OF COAL FROM THE EXPERIMENTAL MINE, CUT THROUGH HUMIC LAYER AND ANTHRAXYLON CHIP. (X 150)

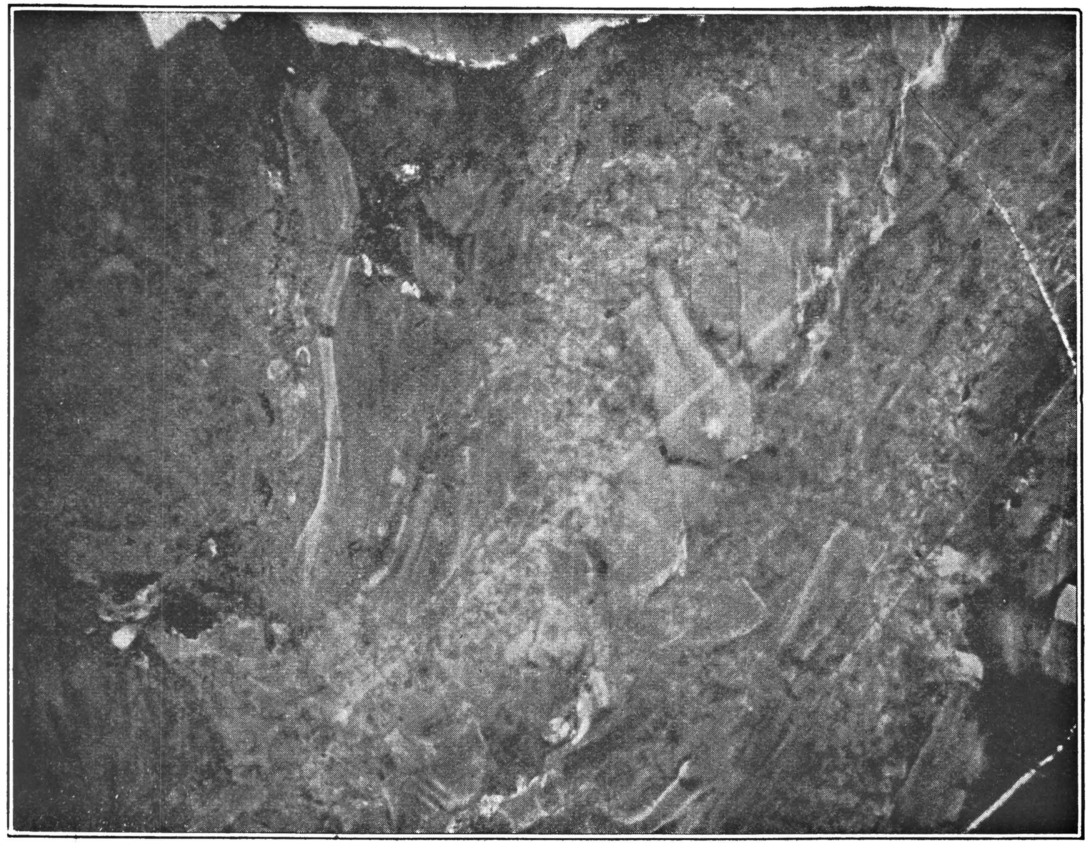

B. THIN HORIZONTAL SECTION OF COAL FROM THEEXPERIMENTAL MINE, CUT THROUGH HUMIC ATTRITUS. (X 150) 


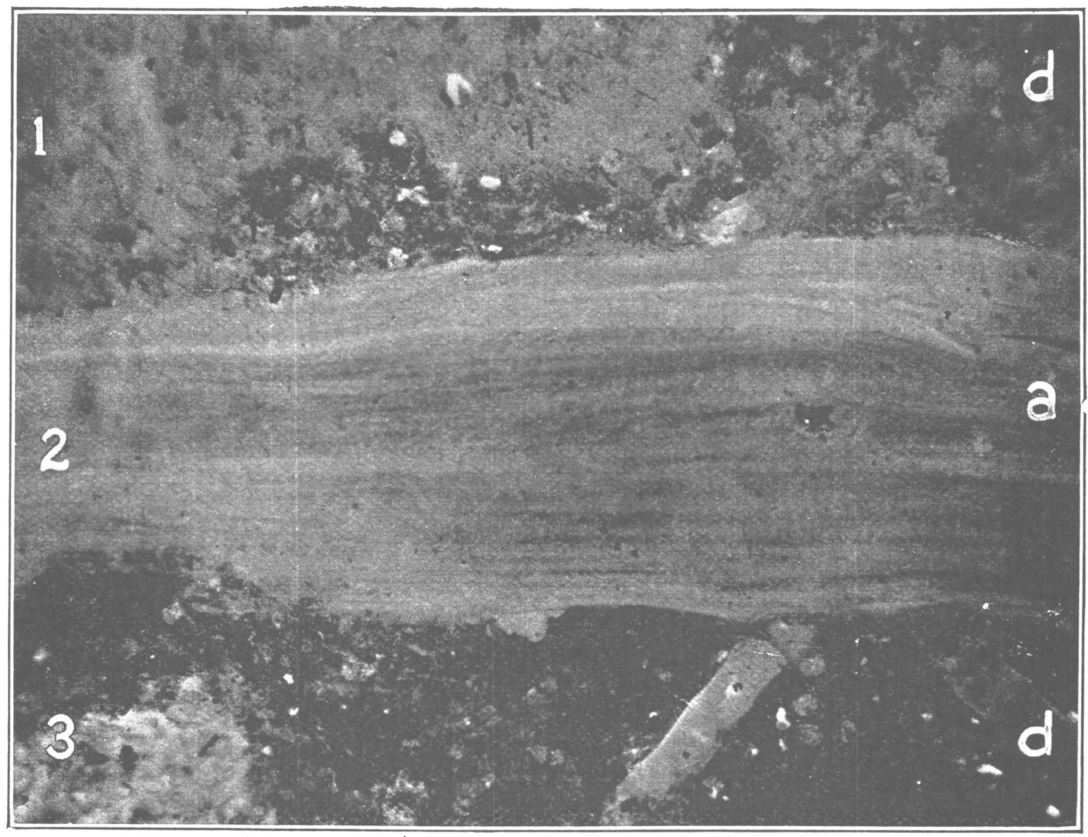

A. VASCULAR STRAND EMBEDDED IN ATTRITUS, COAL FROM EXPERIMENTAL MINE. (X 150)

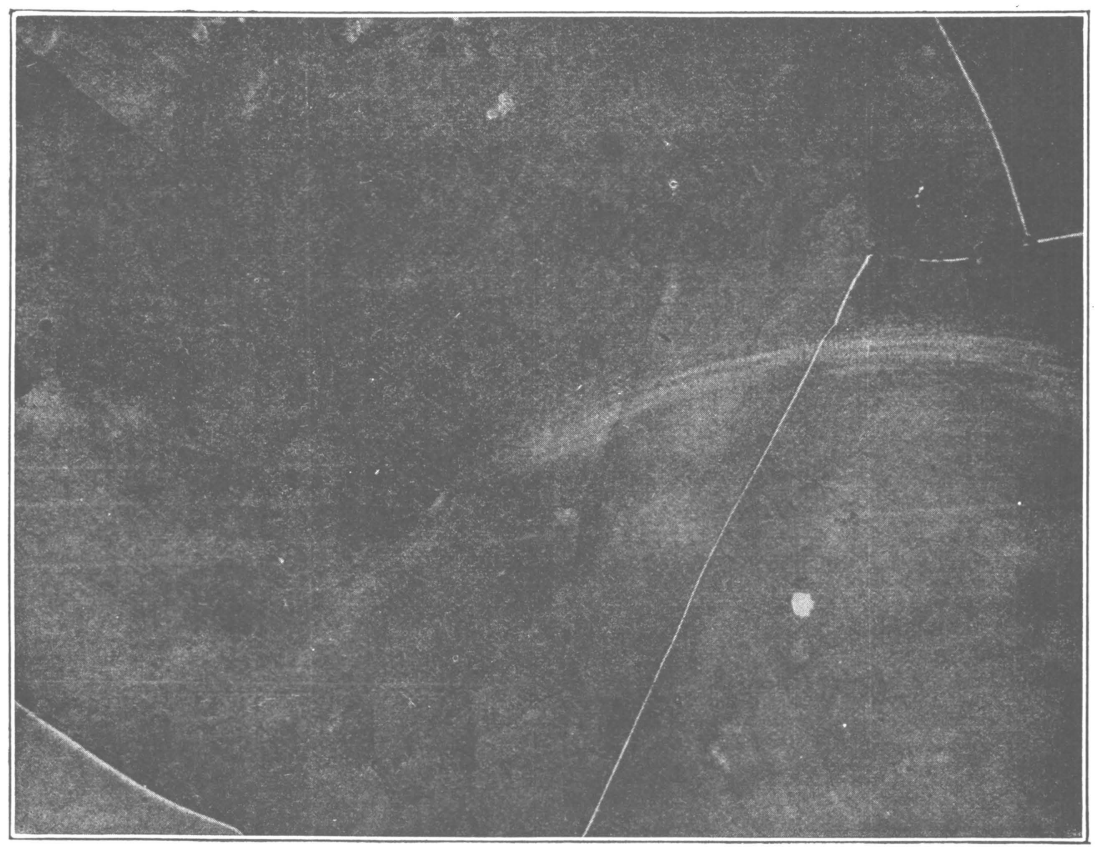

B. THIN HORIZONTAL SECTION OF COAL FROM EXPERIMENTAL MINE, CUT 180 THROUGH TWO OVERLAPPING ANTHRAXYLON CHIPS. (X 150) 


\section{PLATE LXXIII.}

THIN HORIZONTAL SECTIONS.

A. A thin horizontal section of the coal from the Experimental mine $(\times 150)$, showing some of the very well-preserved tissues in this coal. The origin of the tissue embedded in the attritus is not clear, although it resembles in many ways the sporangium walls found in this and other coals.

$B$. A thin horizontal section of the coal from the Experimental mine $(\times 150)$, showing a part of a sporangium wall, embedded in the attritus. A slice of an anthraxylon chip is shown in the upper part of the photograph.

\section{PLATE LXXIV.}

\section{THIN HORIZONTAL SECTIONS.}

A. A thin horizontal section of the coal from the Pittsburgh seam at the Experimental mine $(\times 150)$, showing the general appearance of the attritus in horizontal sections. In the upper part is much disintegrated anthraxylon or humic matter, in the lower half the attritus is carbonaceous and also contains many spore-exines.

$B$. A horizontal section of the coal from the Experimental mine $(\times 200)$, showing large resinous particles, partly covered by and seen through a thin section of anthraxylon on the left. At the upper right note the typical appearance of the attritus as seen in horizontal section; shown also in Plate LXXV, $A$ $(\times 1,000$.)

\section{PLATE LXXV.}

THIN HORIZONTAL SECTIONS.

A. Horizontal section of part of the area shown in the upper right-hand corner of Plate LXXIV, $B(\times 1,000)$, showing in detail the appearance and nature of the predominant spore-exines of the Pittsburgh coal and the general nature of the other constituents of the attritus.

$B$. A thin horizontal section of the coal from the Experimental mine $(\times 1,000)$, showing the attritus partly through a thin slice of anthraxylon, the woody structure of which is evident. The elliptical spore-exine a little to the right of the center, with delicate spines arranged systematically over the surface, is scattered throughout the coal of the Pittsburgh bed.

\section{PLATE LXXVI.}

\section{THIN HORIZONTAL SECTIONS.}

A. A thin horizontal section $(\times 1,000)$ of coal from the Experimental mine, through carbonaceous attritus. The definite particles of the carbonaceous matter are clearly shown. Under the microscope the humic matter is seen to be in a similar state of division, but on account of its refraction of the light the granular appearance is obscured.

$B$. From another thin horizontal section $(\times 1,000)$ of coal from the Experimental mine, showing a condition similar to $A$. Note the great variability in size and form of the pollen-exines represented by the oval or ovoid areas. 


\section{PLATE LXXVII.}

\section{THIN VERTICAL SECTIONS.}

A. A thin cross section of the I'ittsburgh coal from Madison, Pa. $(\times 200)$ showing the more highly carbonaceous nature of the attritus in the coal from this locality. The spore-exines are the same as those from other parts of the Pittsburgh bed. This photograph resembles 1'late IIII, $A$, prepared fron the coal from the oak mine, and plate LXIX, $b$, from the coil from the experimental mine, very closely.

$B$. An areat near the center of $f(\times 1,000)$, showing the constituents in detail.

\section{PLATE LXXVIII.}

\section{THIN CROSS SECTIONS OF THE PITTSBURGH COAL.}

A. A thin cross section of coal from the Pittshurgh seam from an unknown locality $(\times 200)$, showing a strip of resinous anthraxylon, 2-a and $3-a$, between the nonresinous strips 1-il and t-it.

$B$. A thin cross section from coal of the Pittsburgh seam from an unknown locality $(\times 200)$, showing a number of thin anthraxylon strips, 3-a, 5-a, and 7-a, and a carbonaceous attritus, $\$-1$. The spore-exines are of the sume type as those of other localities of the seam.

\section{PLATE LXXIX.}

\section{THIN VERTICAL SECTIONS.}

A. A thin cross section $(\times 200)$ of Pittsburgh coal from an unknown locality, showing a layer rich in humic mitter and carboniceous matter, and relatively few spore-exines. The humic matter consists largely of thin. flat particles.

$B$. A part of the sertion shown in $A(\times 1,000)$. showing a consiclerable num ber of spore-exines, embedded in tine? divided carbonaceous matter and some humic matter.

\section{PLATE LXXX.}

\section{THIN VERTICAL SECTIONS.}

A. A thin cross section $(\times 200)$ of coal of the Pittsburgh seam from an unknown locality, showing a layer of attritus rich in humic matter. consisting largely of thin flat particles, numerous smaller carbonaceons particles, some resinous mitter. and a considerable number of spore-exines. An area from this section is shown in Plate LXXXI, $A . \quad(\times 1,000$.

$B$. A part of the sertion shown in $A(\times 1.000)$. showing the composition of the coal in detail. The anthraxylon strip in the upper part, although exceedingly thin, reveals remaining cell structures. Spore-exines are in white, carbonaceous matter in black, humic matter in gray. 


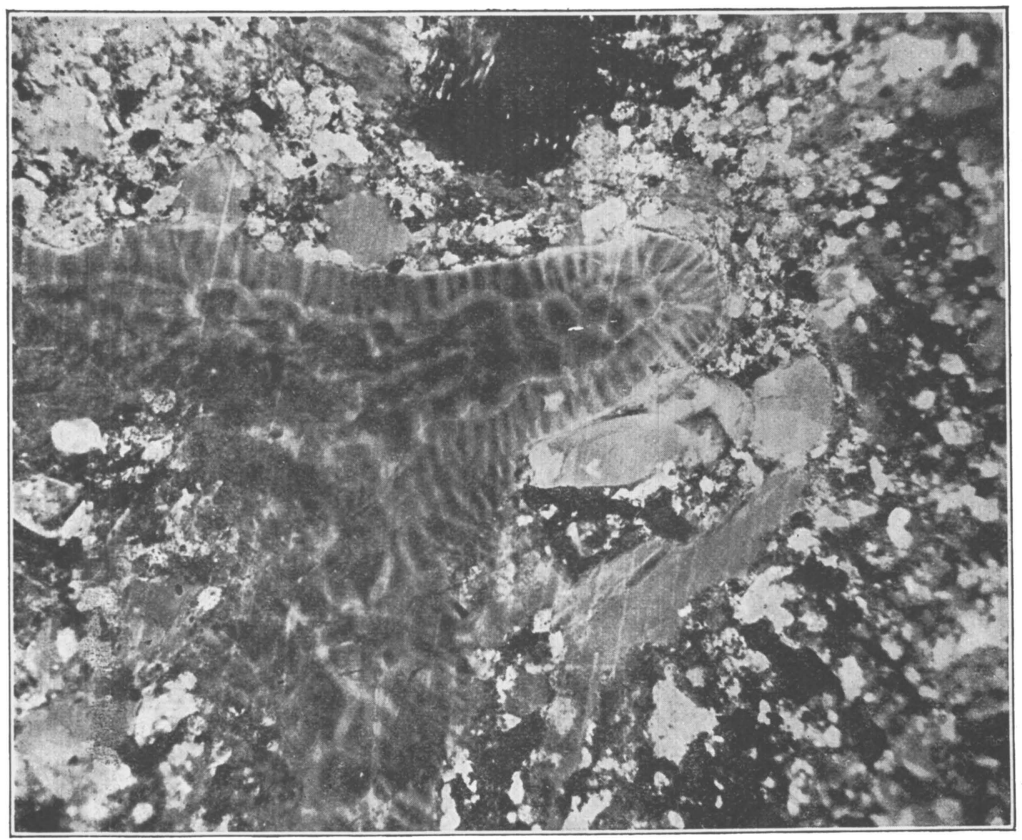

A. TISSUES IN COAL FROM EXPERIMENTAL MINE. (X 150)

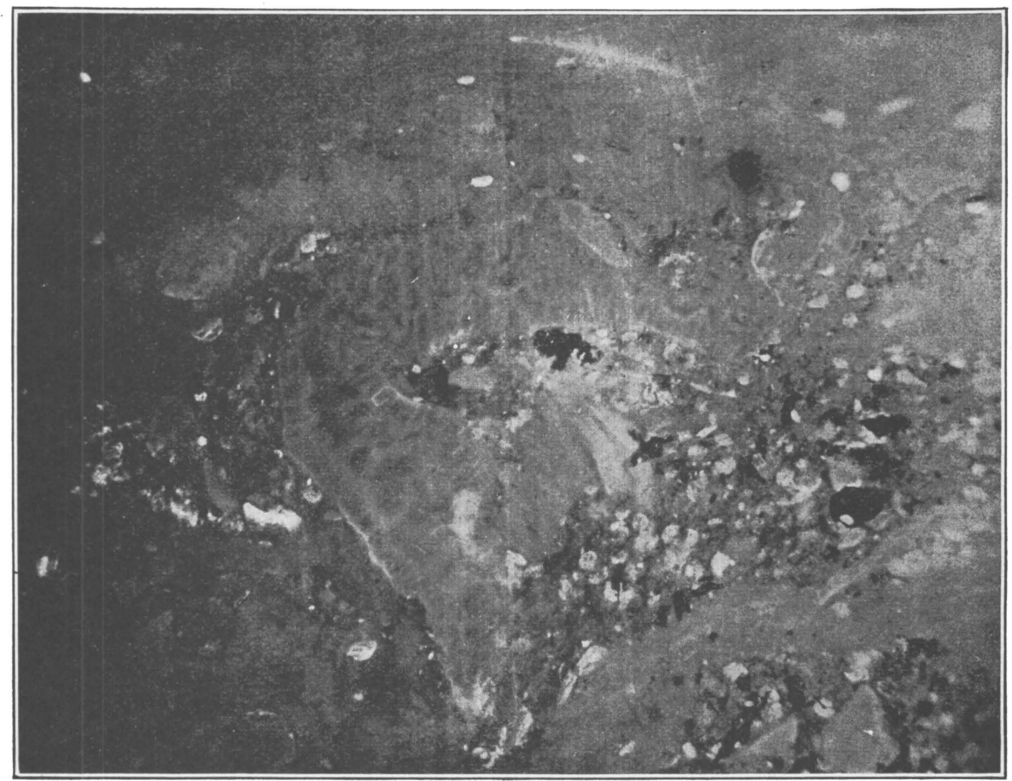

B. SPORANGIUM IN ATTRITUS, COAL FROM EXPERIMENTAL MINE. (X 150) 


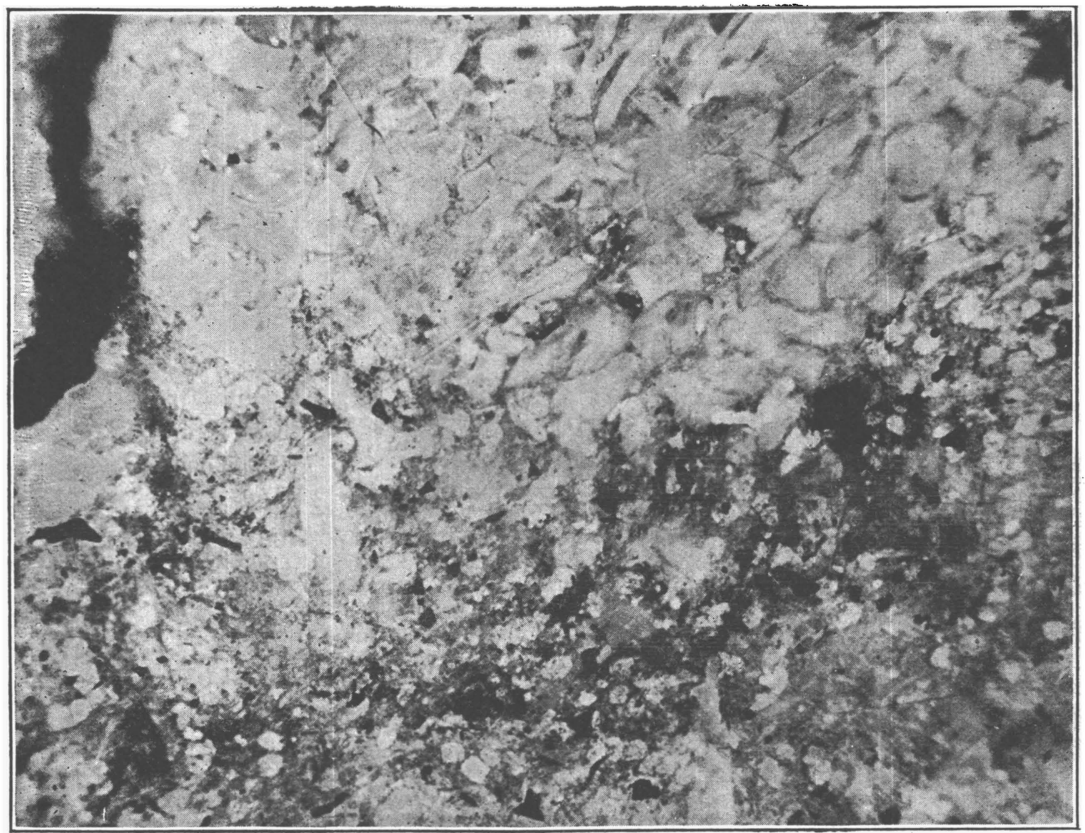

A. GENERAL APPEARANCE OF ATTRITUS, COAL FROM EXPERIMENTAL MINE. (X 150)

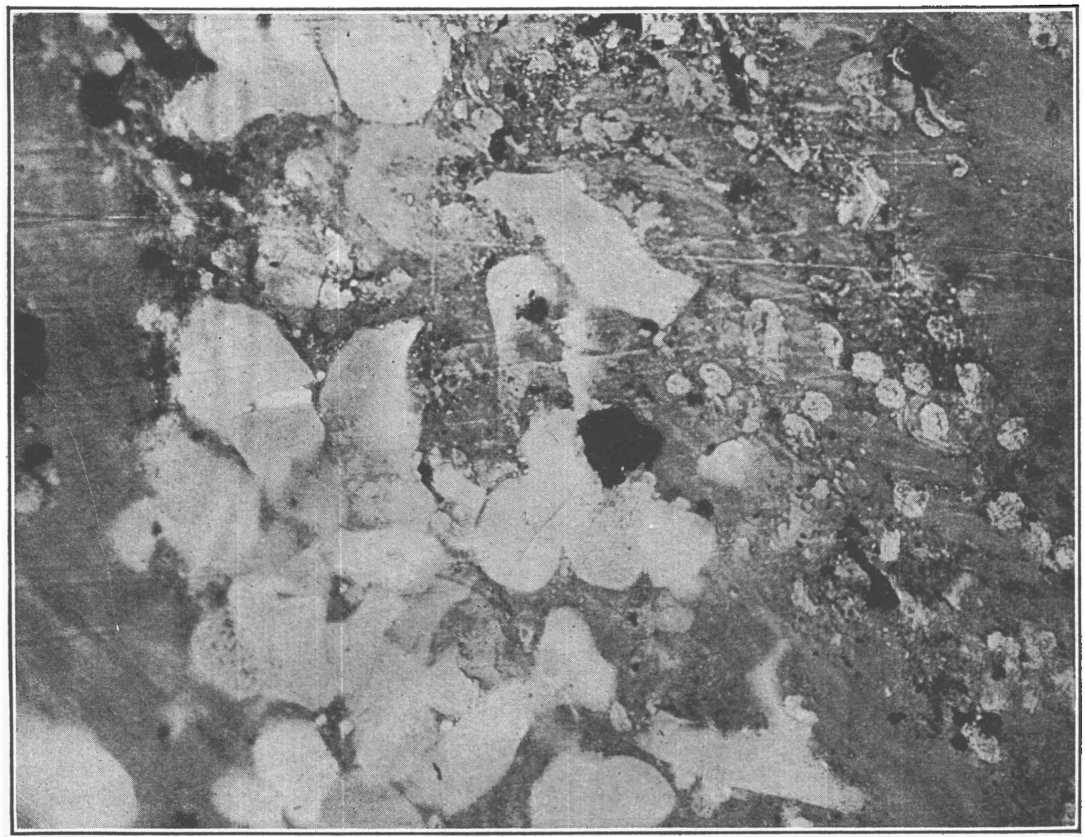

B. RESINOUS PARTICLES IN COAL FROM EXPERIMENTAL MINE. (X 200) 184 


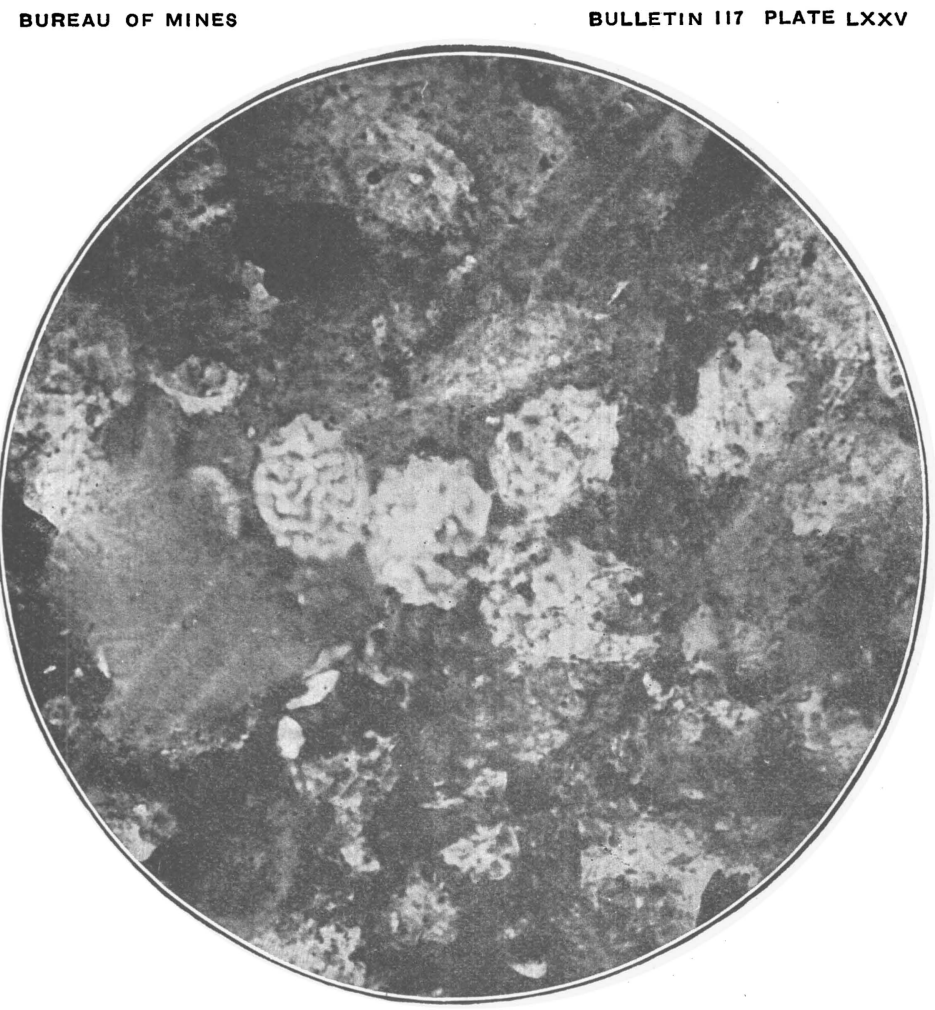

A. AREA FROM SECTION SHOWN IN PLATE LXXIV, B. (X 1000)

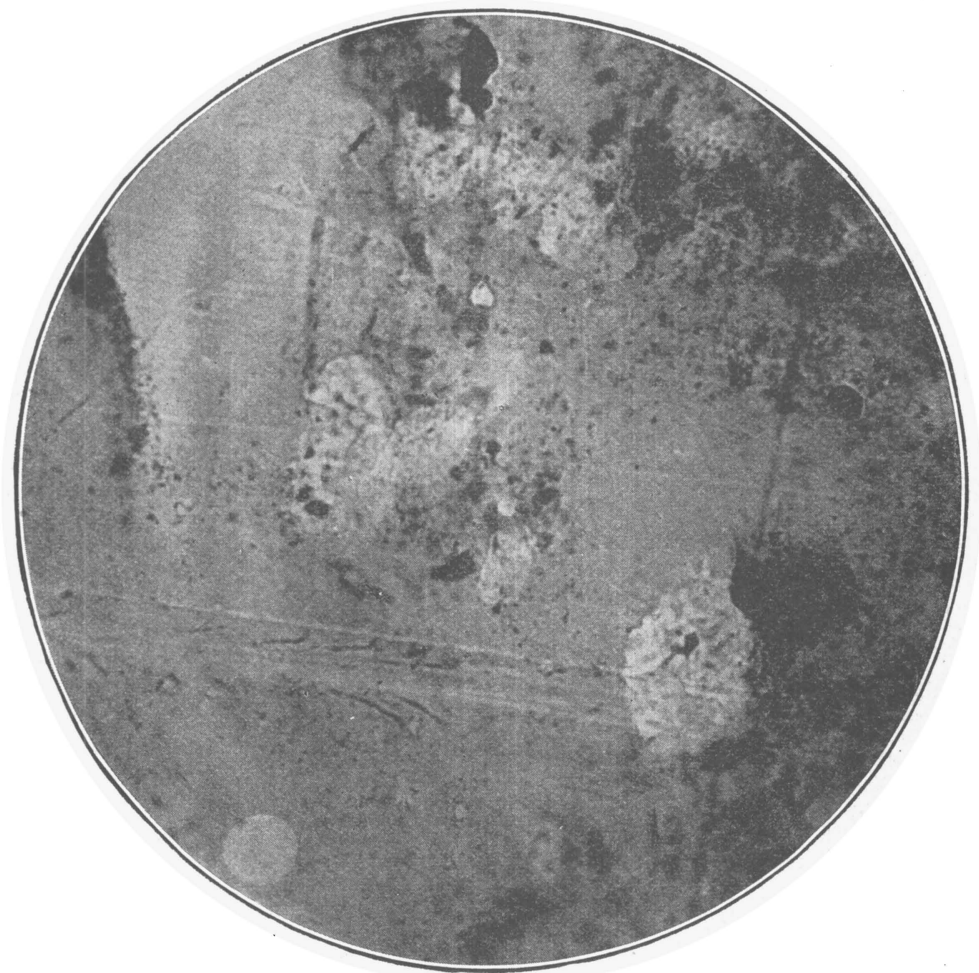

B. THIN HORIZONTAL SECTION OF COAL FROM THE EXPERIMENTAL MINE, SHOWING ANTHRAXYLON AND SPORE-EXINES IN ATTRITUS. (X 1000) 


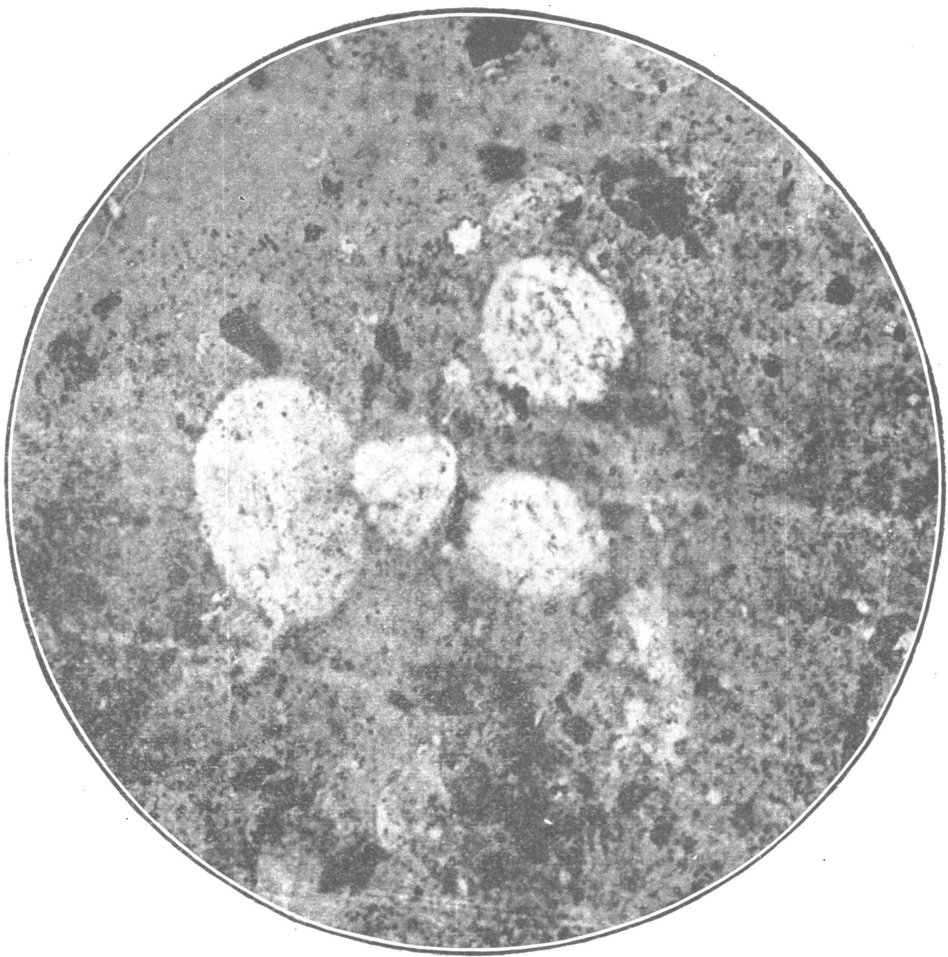

4. THIN HORIZONTAL SECTION (X 1000) OF COAL FROM THE EXPERIMENTAL MINE, THROUGH CARBONACEOUS ATTRITUS.

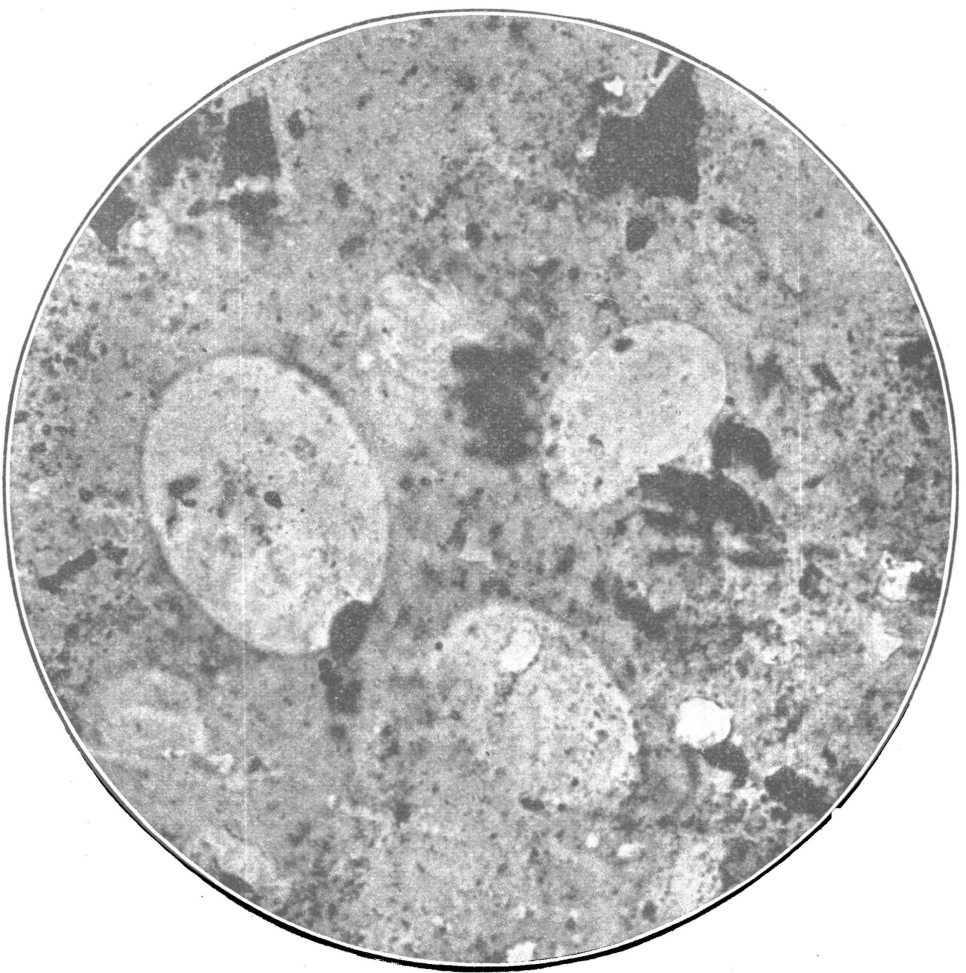

B. ANOTHER SECTION (X 1000) OF COAL FROM THE EXPERIMENTAL 


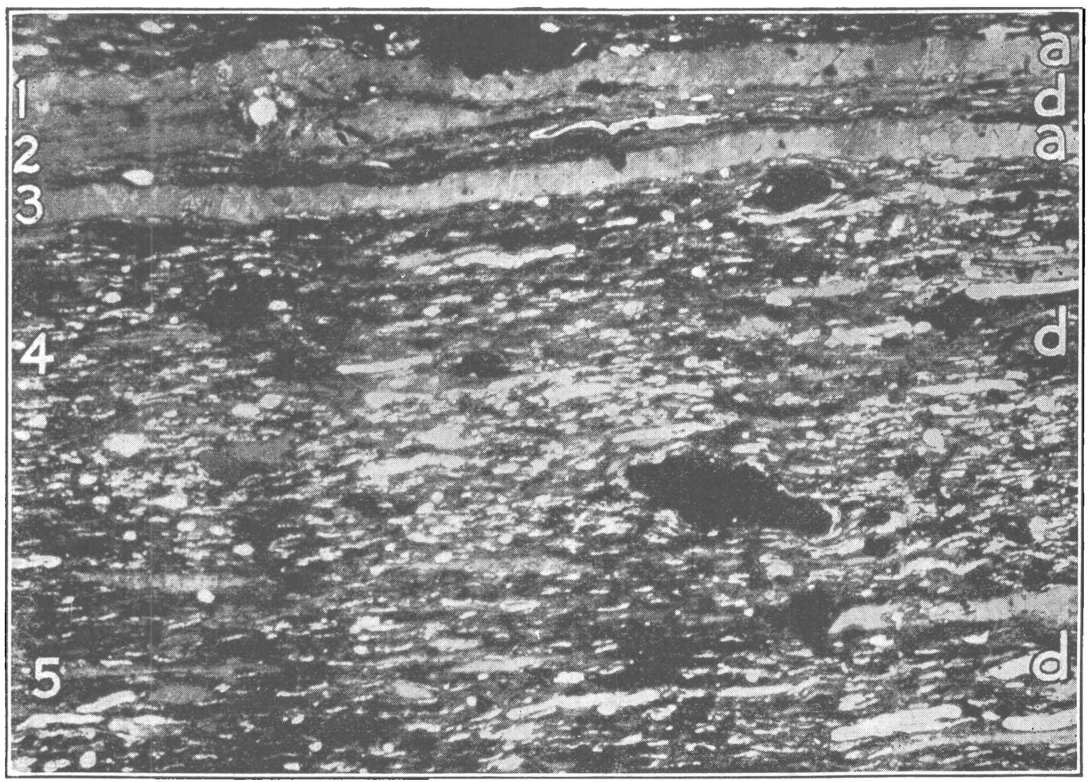

A. THIN VERTICAL SECTION OF COAL FROM MADISON, PA. (X 200)

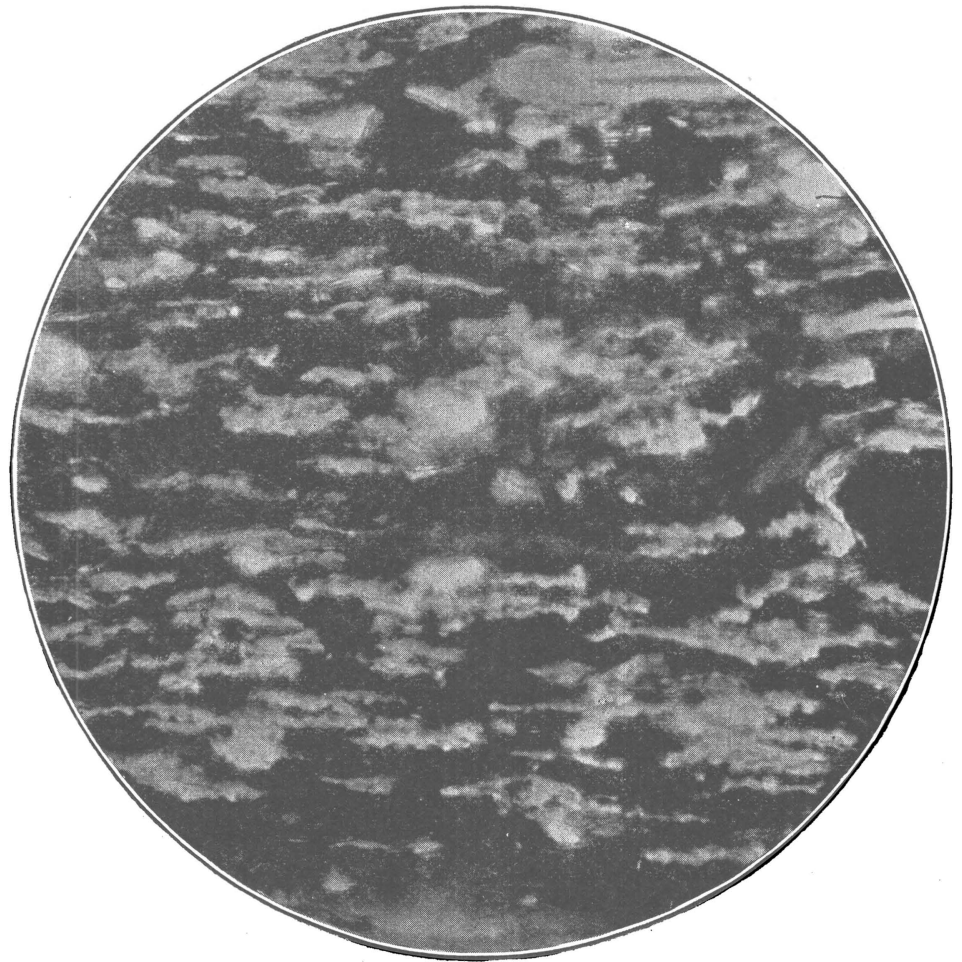

B. AREA FROM NEAR CENTER OF SECTION SHOWN ABOVE. (X 1000) $125536^{\circ}-20-$ Bull. $117-14$ 


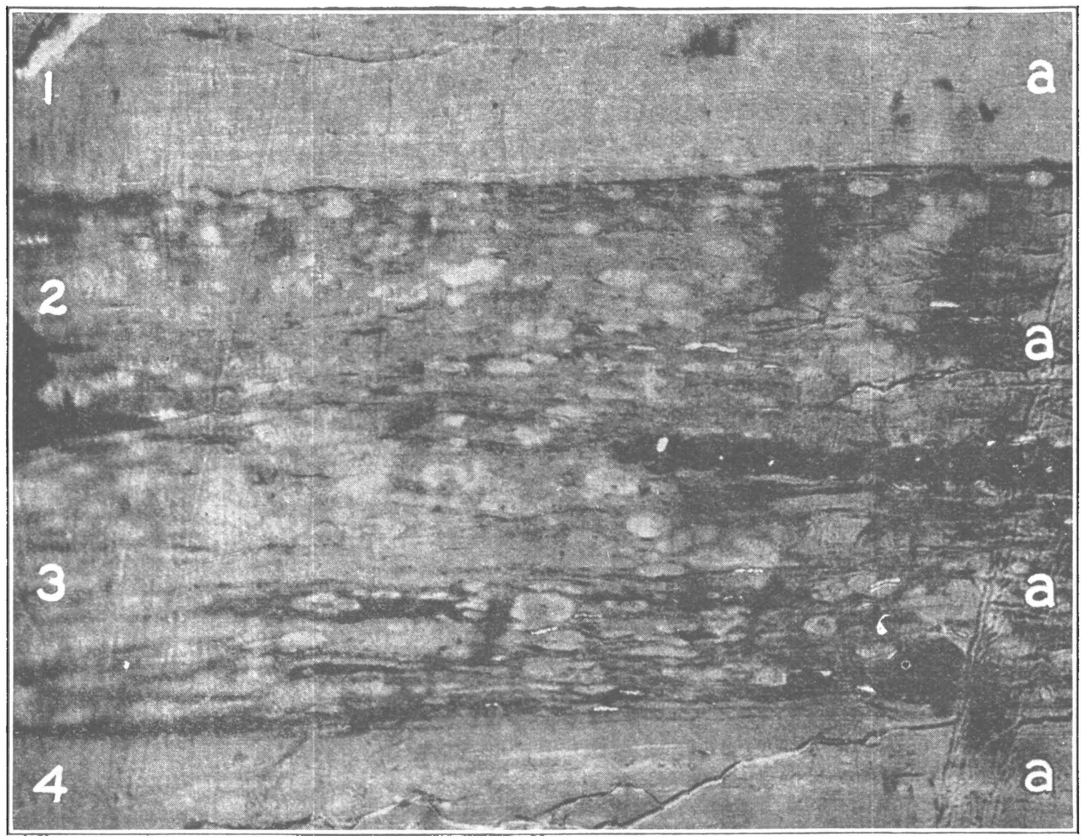

\section{A. RESINOUS AND NONRESINOUS STRIPS OF ANTHRAXYLON IN PITTSBURGH} COAL FROM AN UNKNOWN LOCALITY. (X 200)

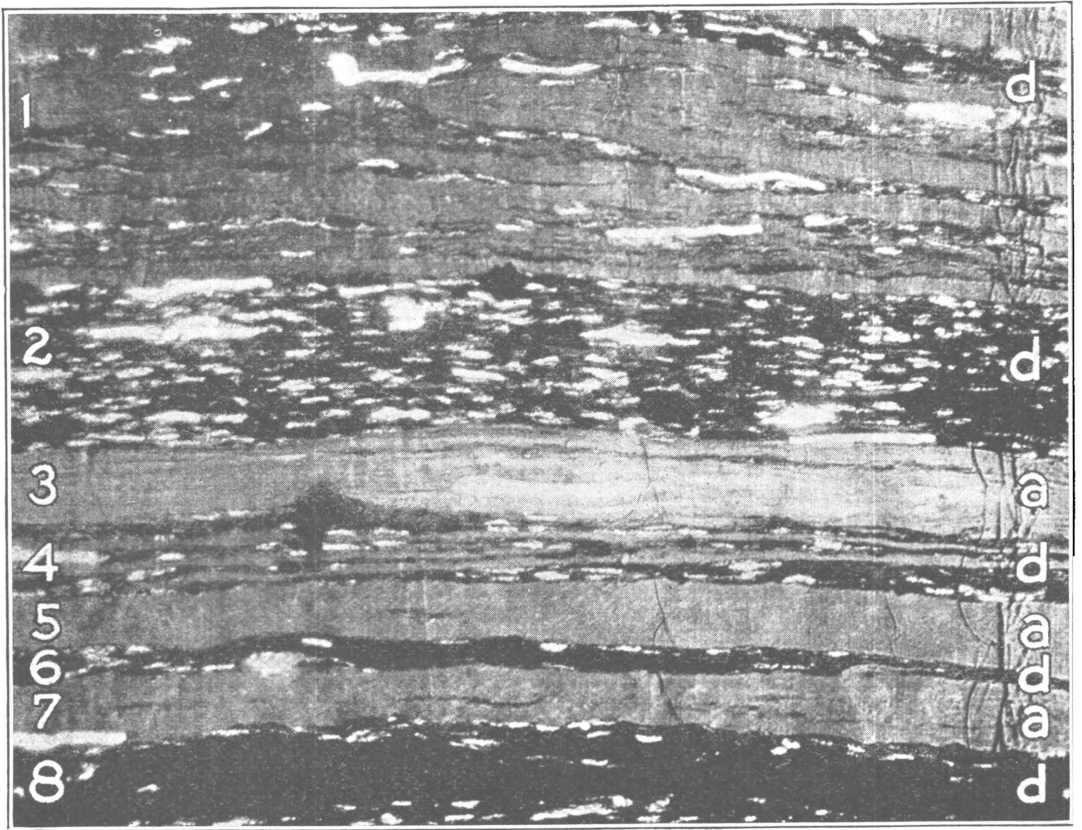

B. SECTION OF PITTSBURGH COAL FROM AN UNKNOWN LOCALITY. (X 200) 188 


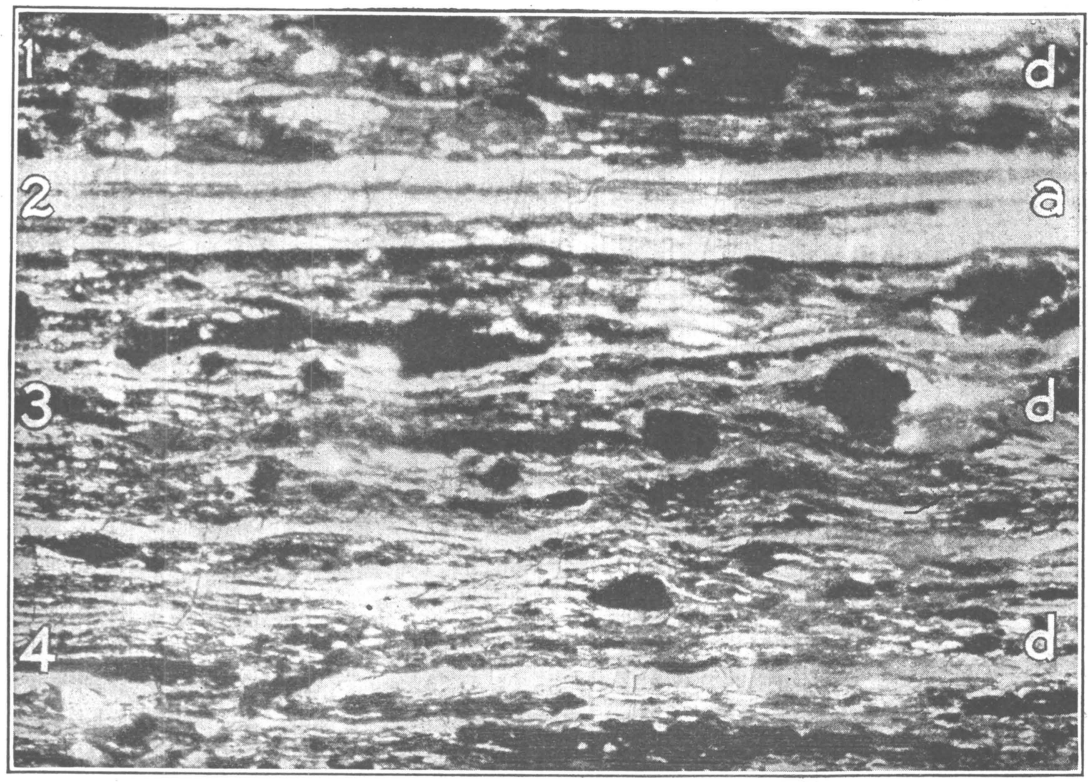

A. THIN VERTICAL SECTION OF COAL FROM THE PITTSBURGH BED, THROUGH A LAYER RICH IN HUMIC AND IN CARBONACEOUS MATTER. (X 200)

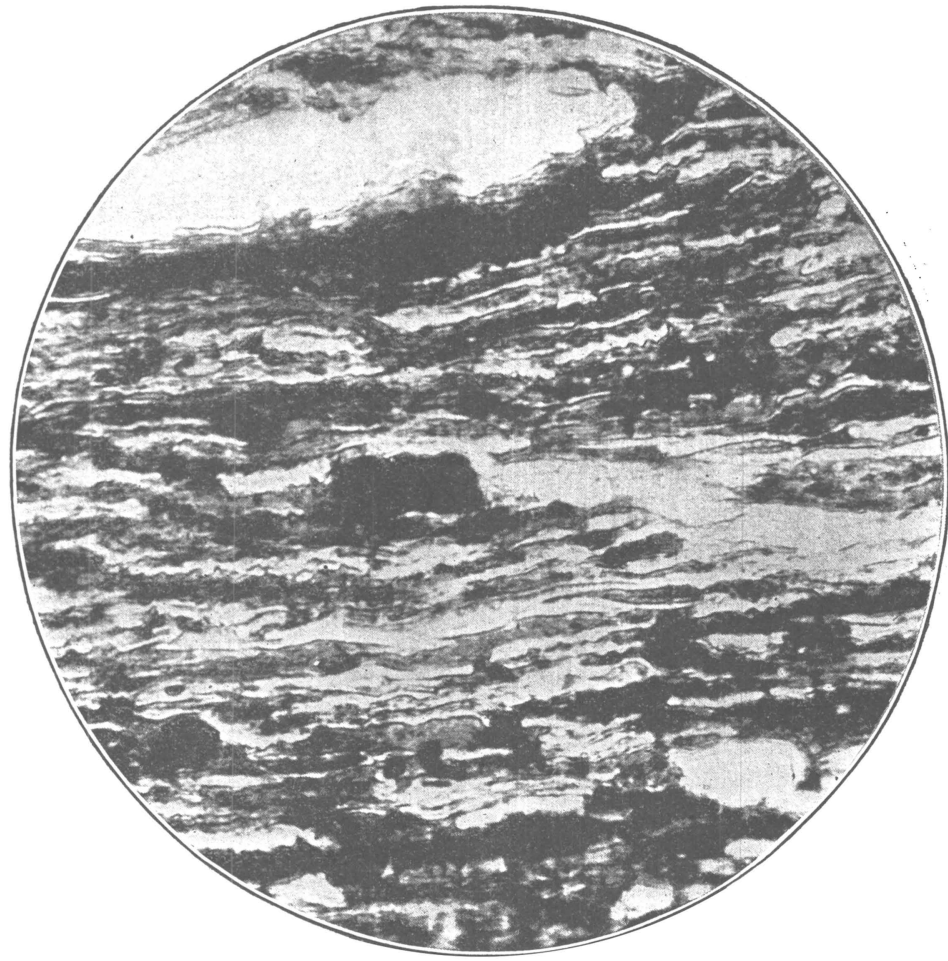

B. PART OF THE SECTION SHOWN ABOVE. (X 1000) 


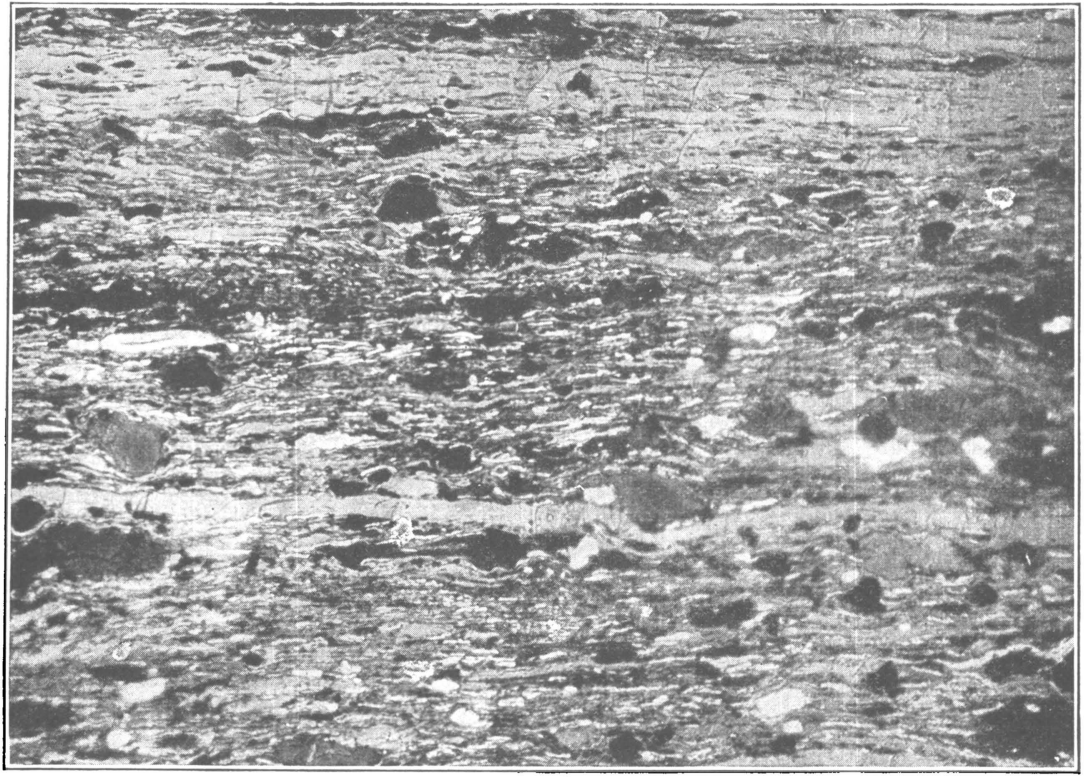

A. THIN CROSS SECTION OF COAL FROM THE PITTSBURGH BED, SHOWING A LAYER RICH IN HUMIC MATTER. (X 200)

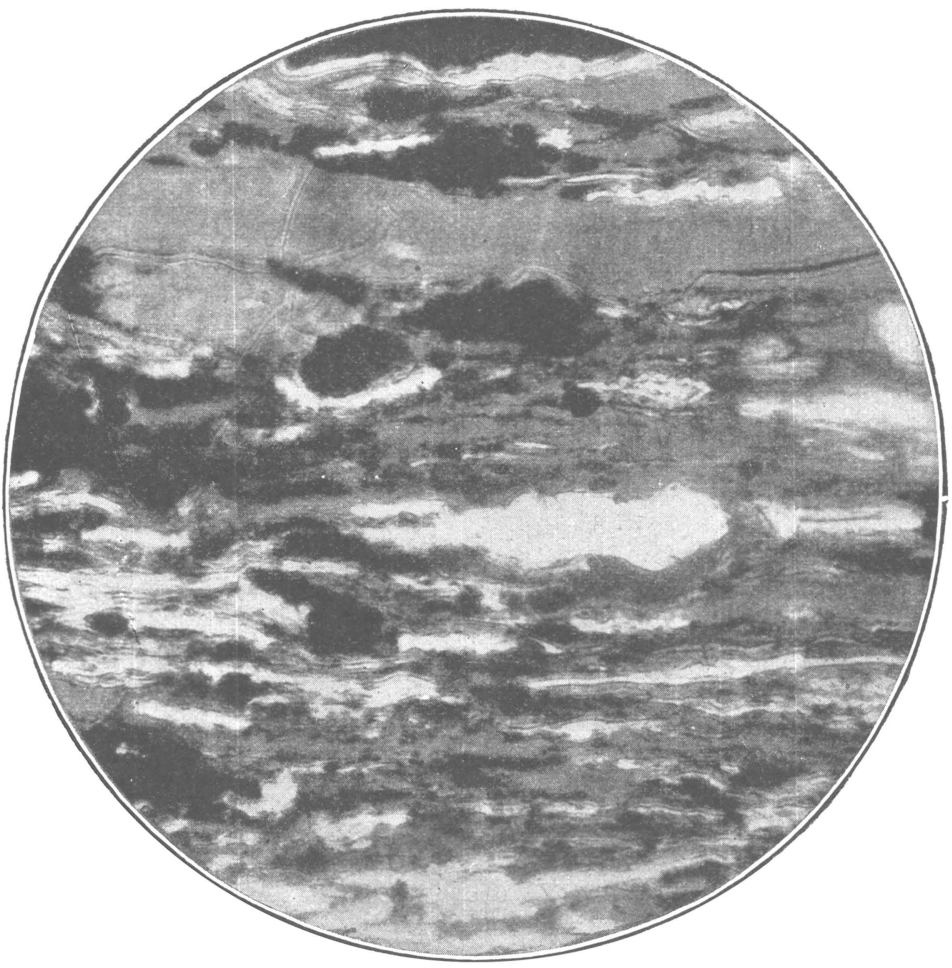

B. PART OF SECTION SHOWN ABOVE. (X 1000) 


\section{PLATE LXXXI.}

\section{THIN VERTICAL SECTIONS.}

A. Another part of the section shown in Plate LXXX, $A(\times 1,000)$, showing the type of megaspore characteristic of the Pittsburgh coal. The crenulated outline is due to sculpturing.

B. A type of cuticle, shown in cross section $(\times 200)$, abundant in the Pittsburgh coal.

\section{PLATE LXXXII.}

\section{ISOLATED SPORE-EXINES AND A POLLEN GRAIN.}

1. An isolated spore-exine $(\times 1,000)$ predominant in the Pittsburgh coal.

2. The same type of spore-exine $(\times 2,000)$, photographed from a horizontal section with the exine in situ. (The white specks are due to defects in the negative.)

3. Another exine common in this coal. $(\times 1,000$. $)$

4. One of the pollen grains abundant in the Pittsburgh coal. $(X 1,000$.

5. A spore-exine of a remarkable type $(\times 200)$, in situ, in a cross section, occasionally found in the Pittsburgh coal.

\section{PLATE LXXXIII.}

\section{BARKLIKE TISSUES.}

Thin vertical section of Pittsburgh coal showing barklike tissues. Such tissues are preserved irregularly, consist of relatively large cells and include many resinous particles.

\section{PLATE LXXXIV.}

\section{THIN VERTICAL SECTIONS.}

A thin cross section of coal $(\times 200)$, from the Jagger bed, Carbon Hill, Ala. A humic attritus is shown at $1-d$ in which are a number of spore-exines and fragments of a megaspore, 2-sp; a humic lamina 4-d separates the thin anthraxylon strip at 3-a from the anthraxylon strip 5-a. The anthraxylon strip at 6-a shows remarkably well-preserved cell structure. 


\section{PLATE LXXXV.}

THIN VERTICAL SECTION.

A thin cross section $(\times 200)$ of coal from Carbon Hill, Ala., showing an anthraxylous layer. The strip at 4-a has retained its cell structure remarkably well.

\section{PLATE LXXXVI.}

\section{THIN VERTICAL SECTION.}

A thin cross section $(\times 200)$ of coal from Carbon Hill, Ala., showing a layer of humic attritus that includes a number of resinous particles, 2-d, few sporeexines, and little carbonaceous and earthy matter.

\section{PLATE LXXXVII.}

\section{THIN VERTICAL SECTION.}

A thin cross section $(\times 200)$ of the coal from Carbon Hill, Ala., showing the character of the anthraxylon components often found in this coal. The woody structure at 1-a and $3-\mathrm{d}$ is largely effaced, whereas at 2-a it is remarkably well preserved.

\section{PLATE LXXXVIII.}

\section{THIN VERTICAL SECTIONS.}

A. A typical thin cross section $(\times 200)$ of the attritus of the coal from Carbon Hill, Ala. As in other coals, no fast line of distinction can be drawn between the anthraxylon and the humic matter. The former is usually distinguished by its size and remains of cell structure.

$B$. A part of the section shown in $A(\times 1,000)$, showing the nature of the spore-exines in cross section. They differ from those of the Pittsburgh coal or those of any other bed. 


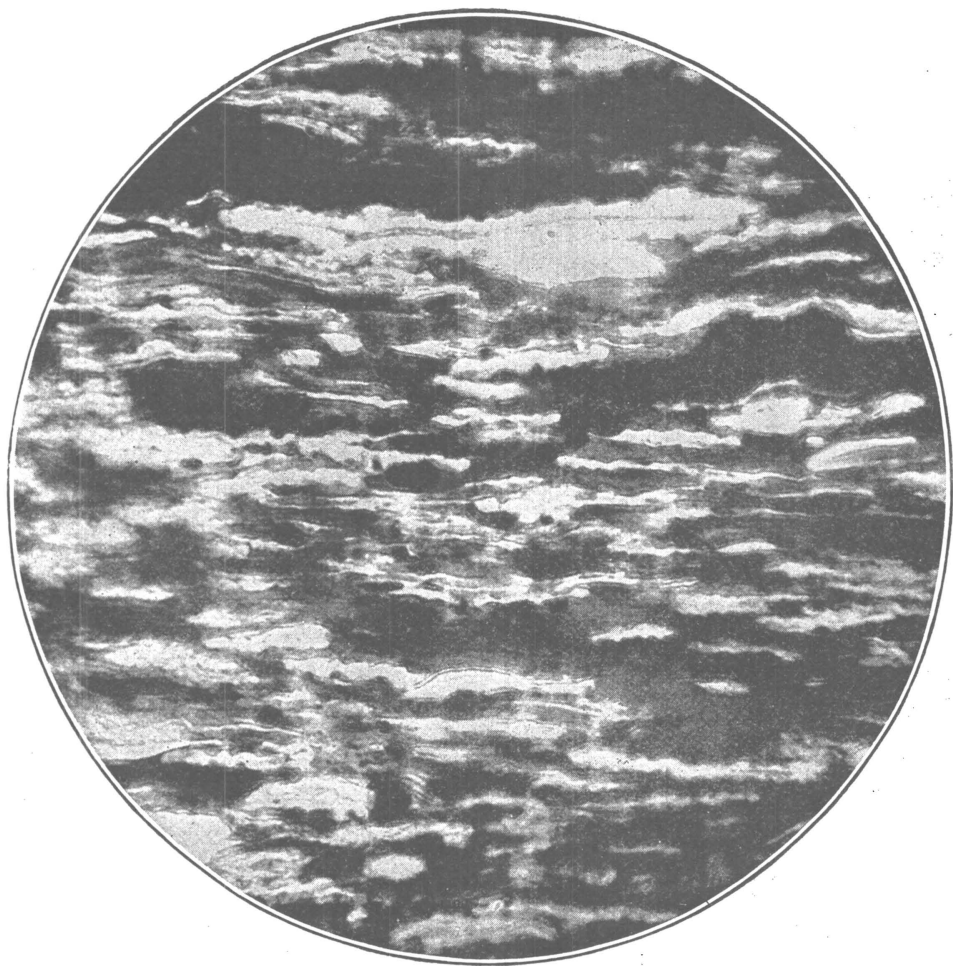

A. ANOTHER PART OF.THE SECTION SHOWN IN PLATE LXXX, $A . \quad(X 1000)$

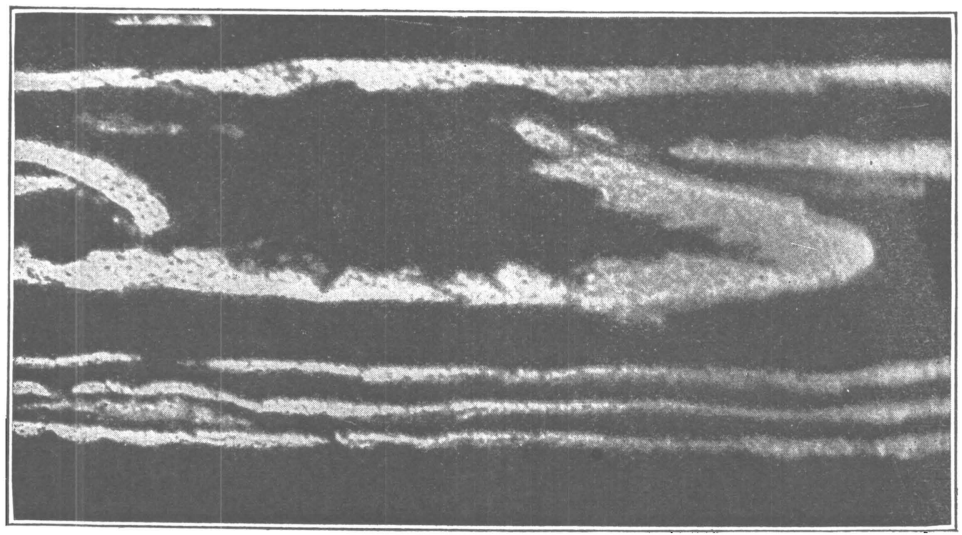

B. THIN CROSS SECTION OF CUTICLE IN PITTSBURGH COAL. (X 200) 


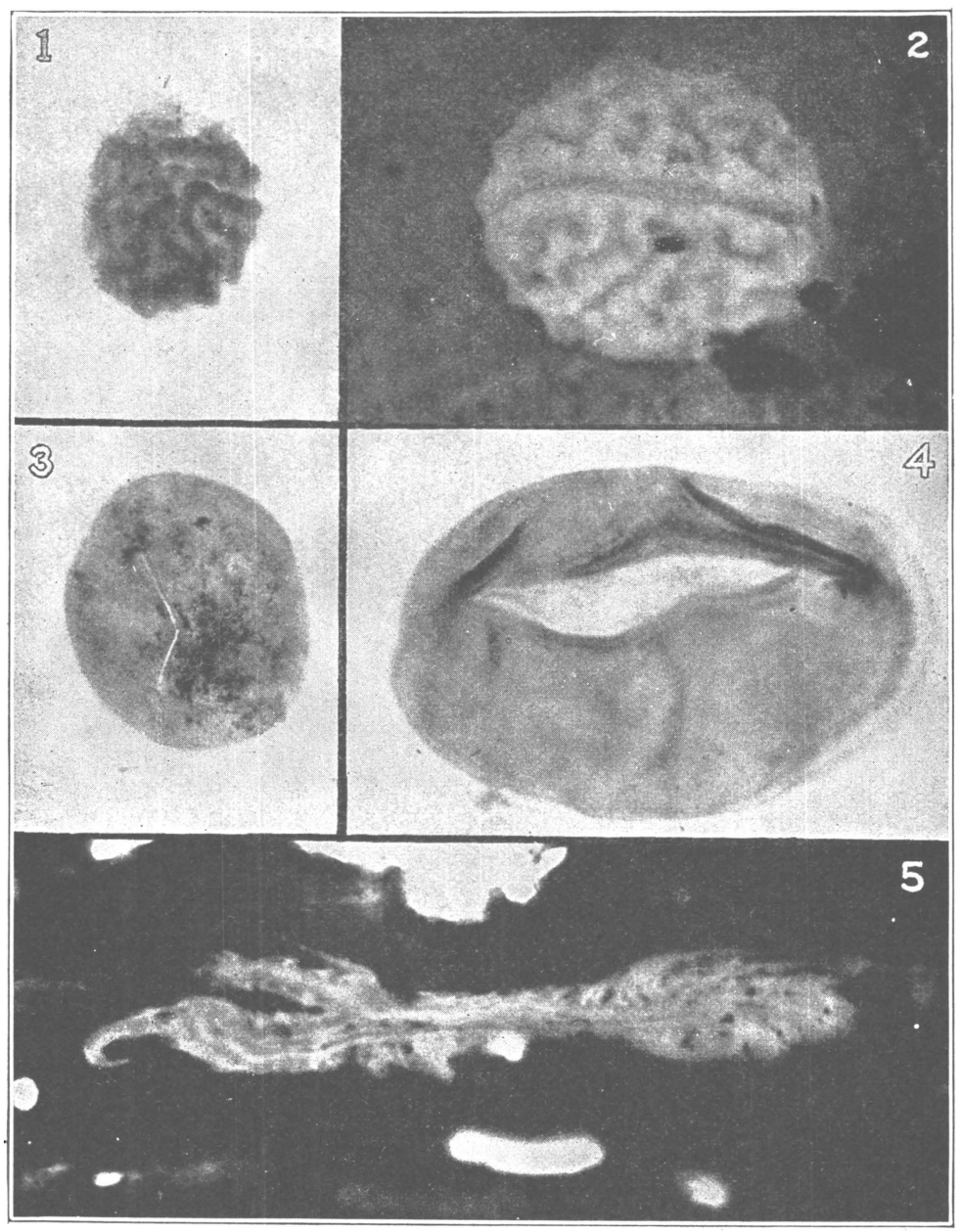

SPORE-EXINES AND A POLLEN GRAIN FROM THE PITTSBURGH COAL. 194 


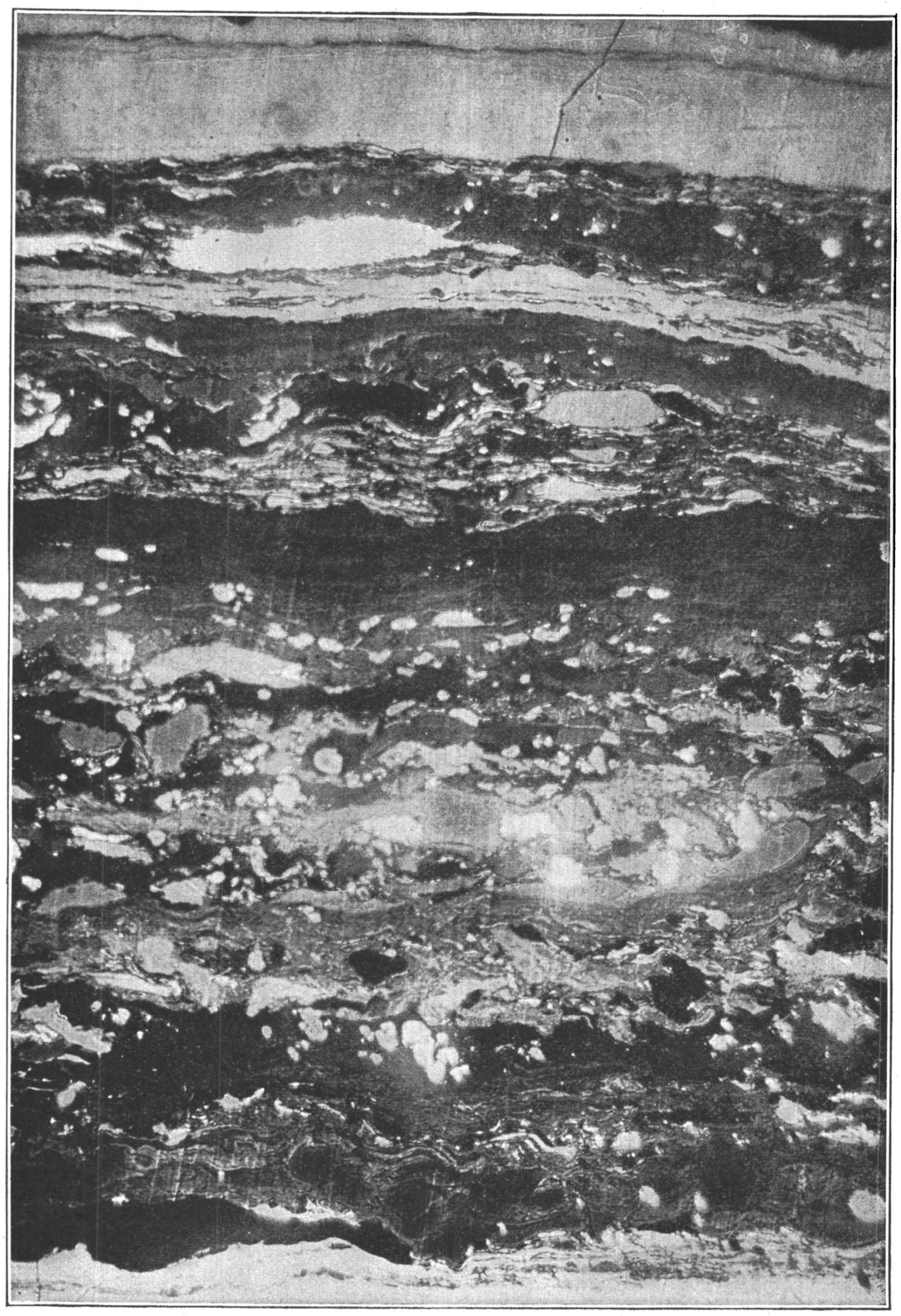

THIN VERTICAL SECTION OF PITTSBURGH COAL, SHOWING BARKLIKE TISSUES 


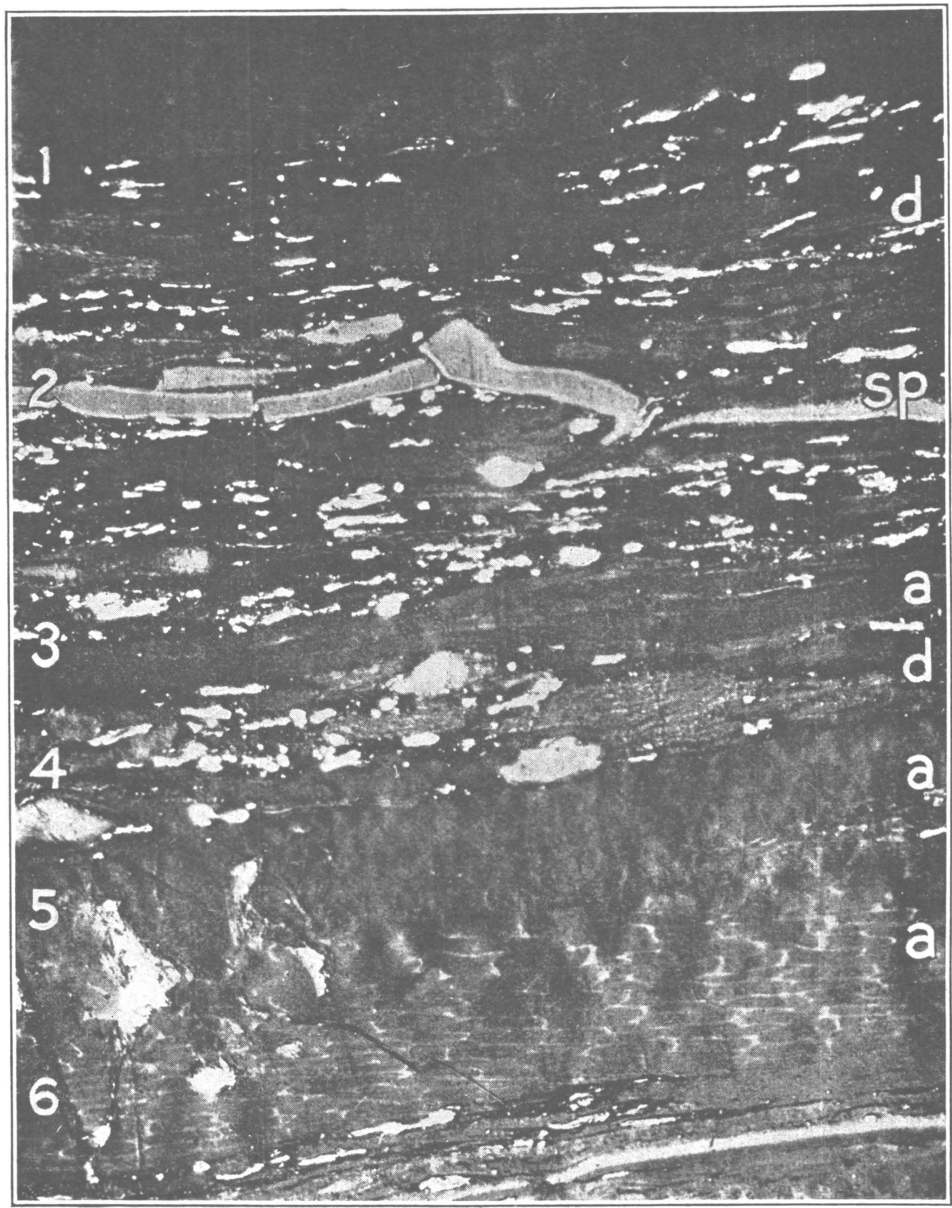

THIN VERTICAL SECTION OF COAL FROM CARBON HILL, ALA. (X 200) 196 


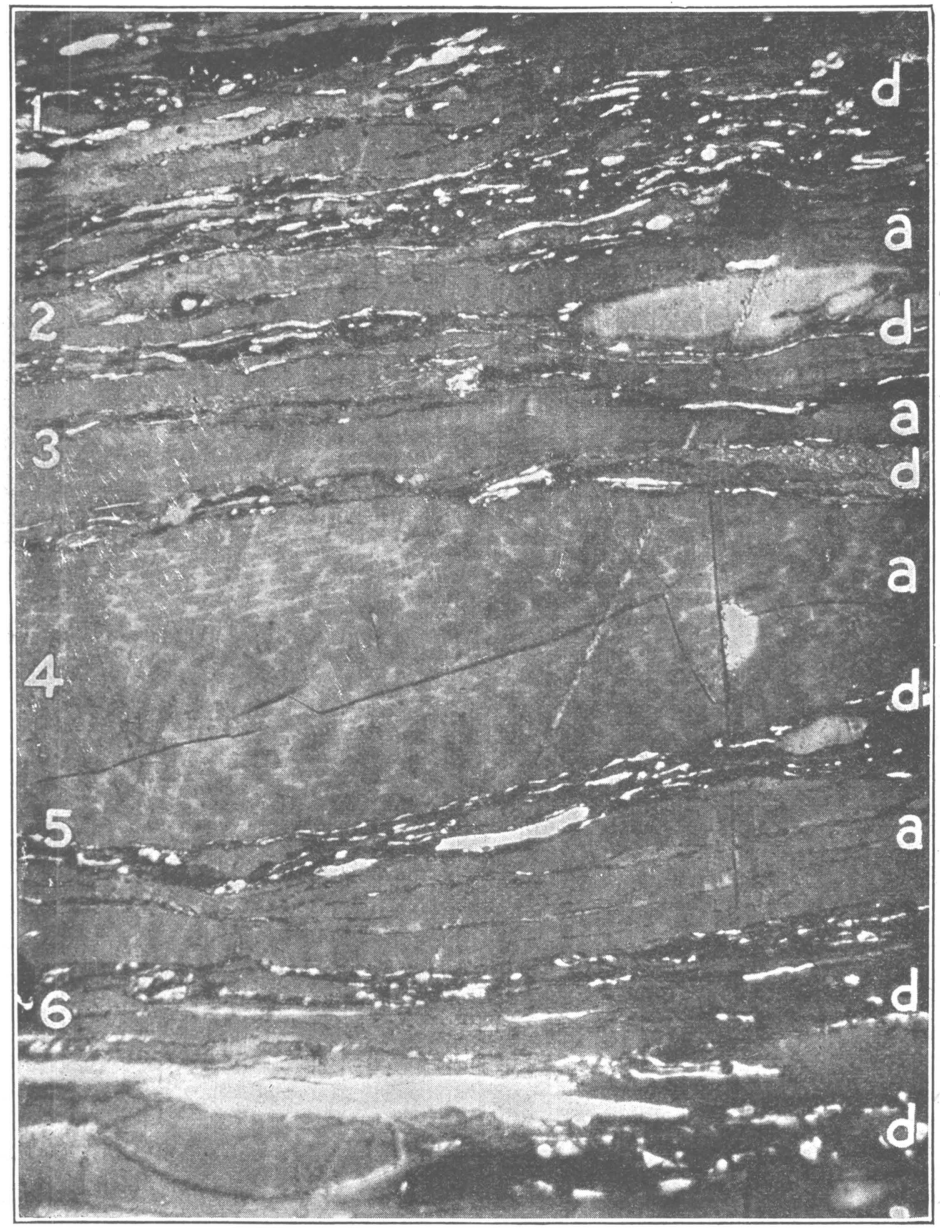

THIN SECTION OF COAL FROM CARBON HILL, ALA., SHOWING AN ANTHRAXYLOUS LAYER. (X 200) 


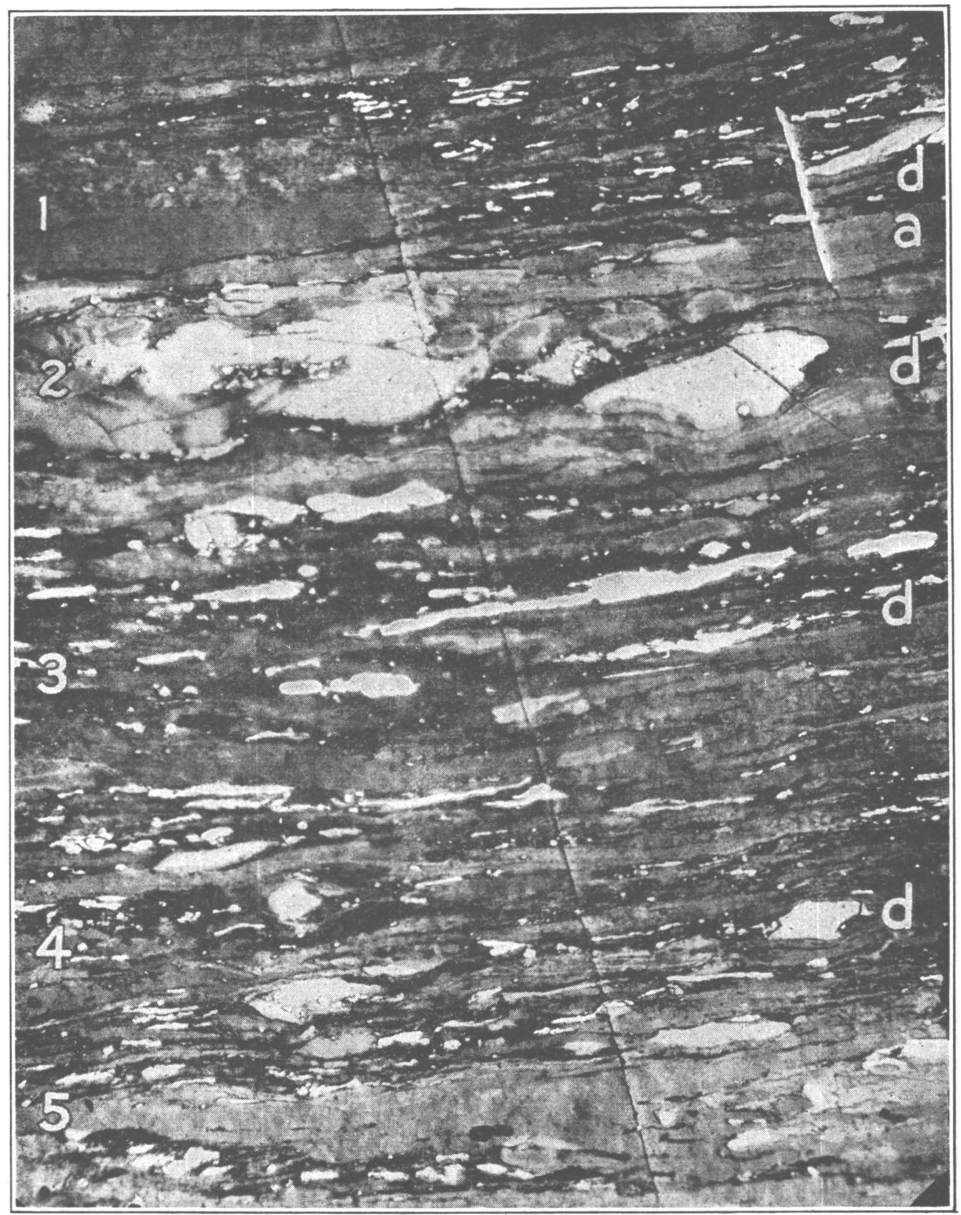

THIN VERTICAL SECTION OF COAL FROM CARBON HILL, ALA., SHOWING A LAYER OF HUMIC ATTRITUS. (X 200) 


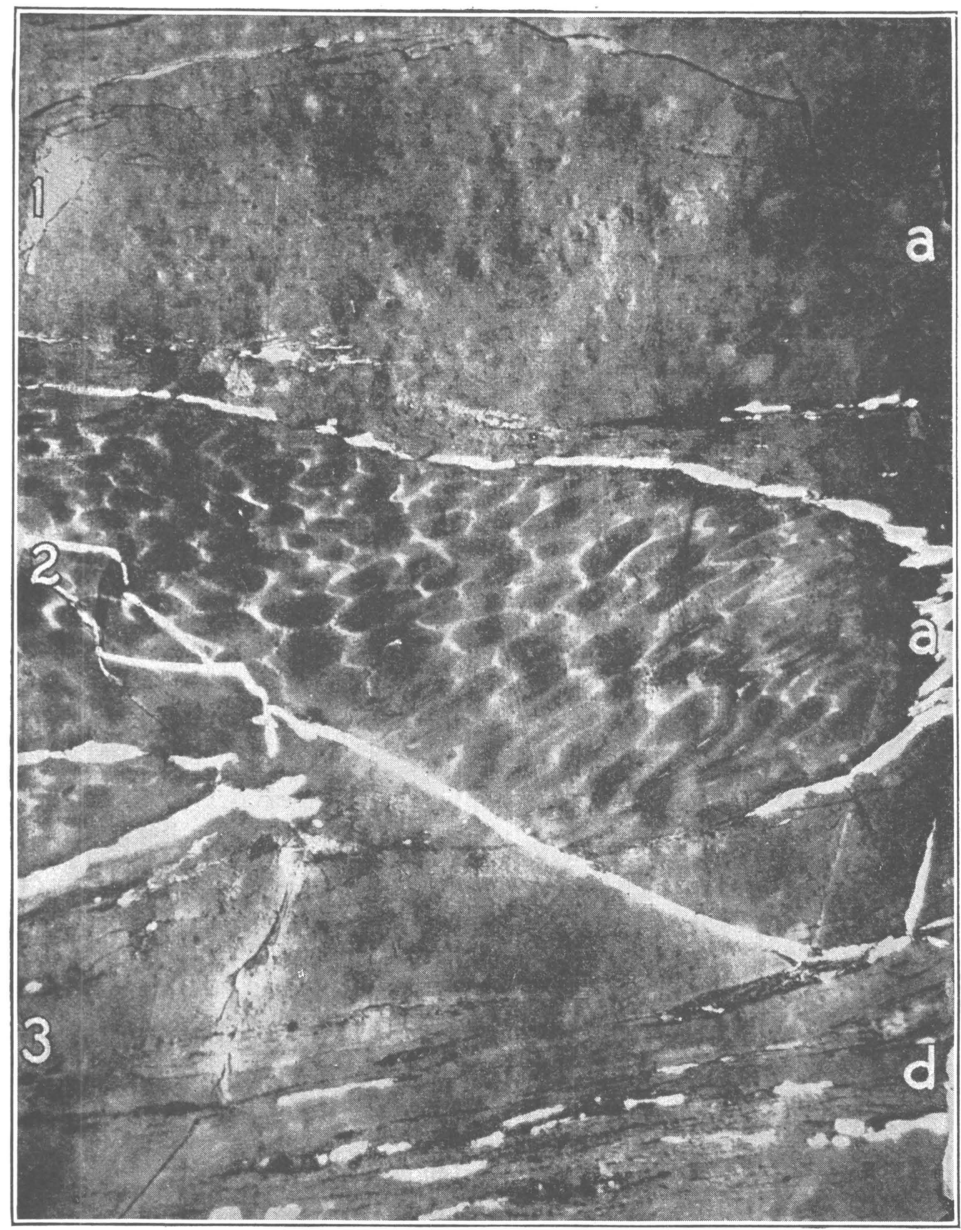

THIN VERTICAL SECTION OF COAL FROM CARBON HILL, ALA., SHOWING CHARACTER OF ANTHRAXYLON COMPONENTS. (X 200) 


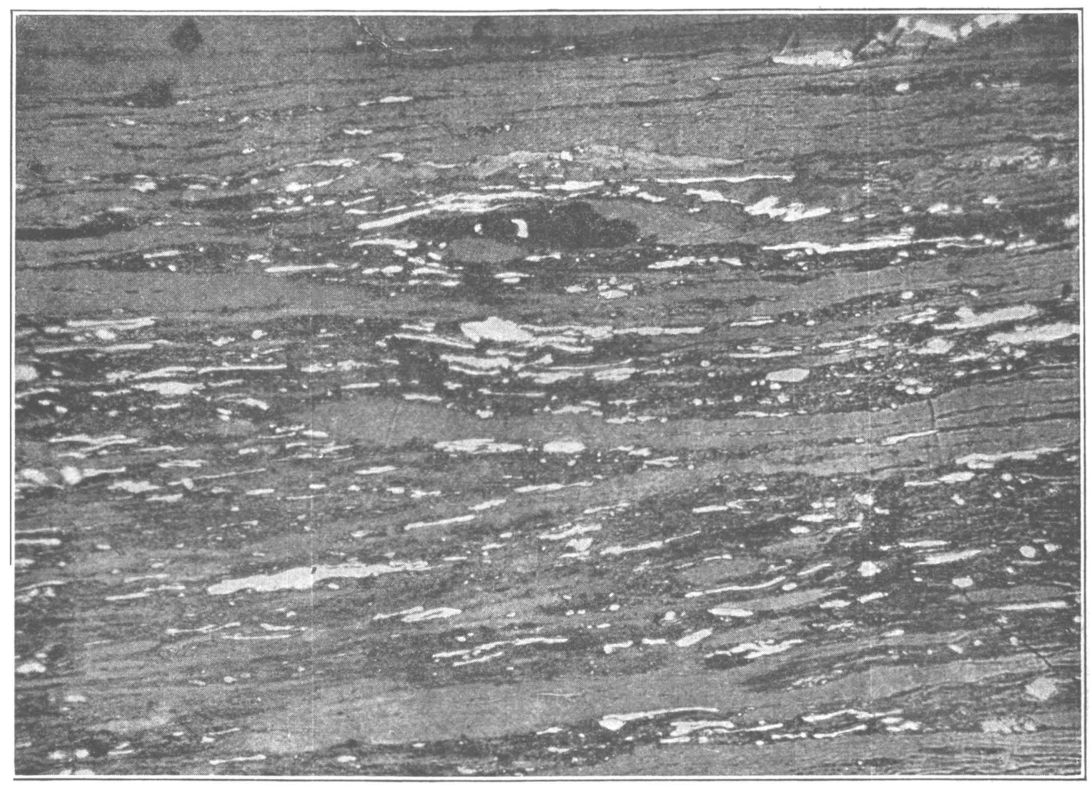

1. TYPICAL CROSS SECTION OF ATTRITUS OF COAL FROM CARBON HILL, ALA. (X 200)

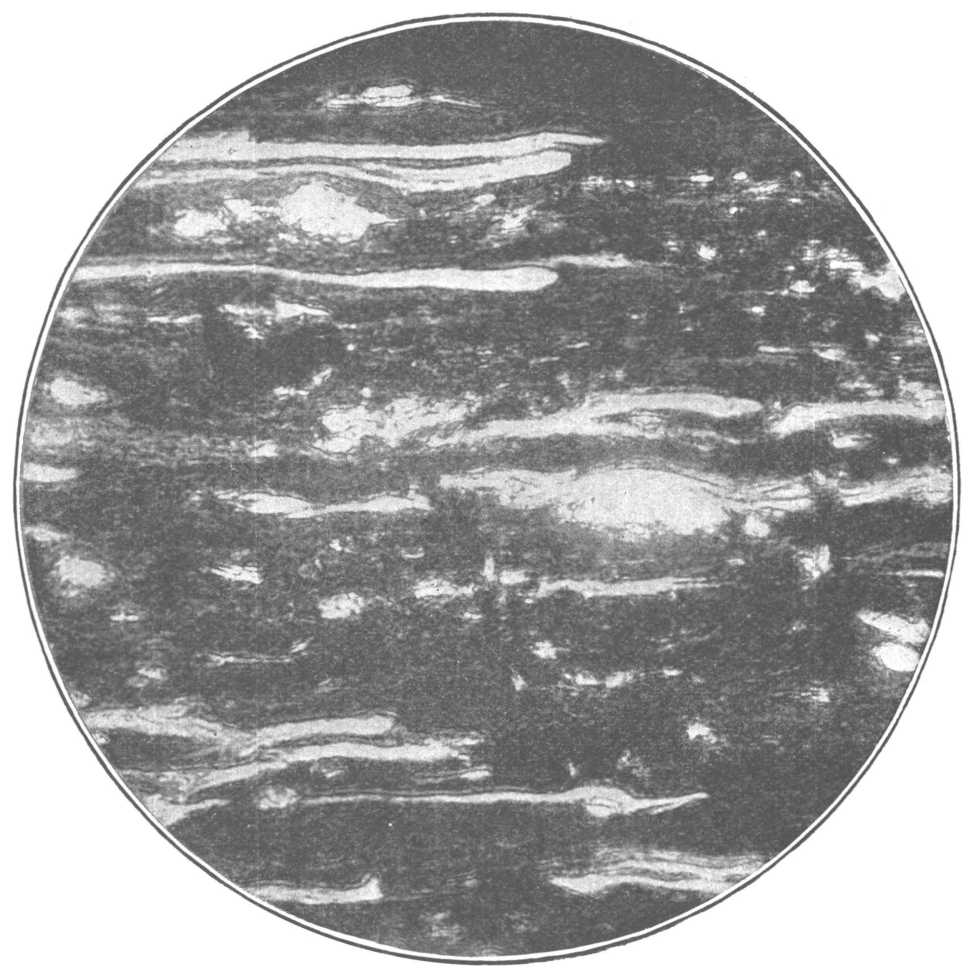




\section{PLATE LXXXIX.}

\section{THIN VERTICAL SECTIONS.}

A. A thin cross section of coal from the mine of the Hart-IVilliams Coal Co., near Benton, Ill. ( $\times 200$ ), showing a part of a lamina of attritus composed of about equal amounts of humic matter, spore-exines, and carbonaceous matter. The strips at 2-a and 4-a represent thin chips of anthraxylon.

$B$. A part of the section illustrated in $A(\times 1,000)$, showing the nature of the constituents in detail. Spore-exines are in white, humic matter and anthraxylon in gray, and carbonaceous and earthy matter in black. The remains of the cell structure in the anthraxylon chip in the lower part are shown by striations.

\section{PLATE XC.}

\section{THIN VERTICAL SECTIONS.}

$A$. and $B$. Parts of thin sections of coal from the Hart-Williams mine $(\times 1,000)$, showing the nature of the humic matter, carbonaceous matter, and the types of spore-exines found in this coal. Three types may easily be observed.

\section{PLATE XCI.}

\section{'THIN VER'TICAL SECTION.}

A. A thin vertical section of a larger anthraxylon component of the HartWilliams coal. At a lower magnitication this component appeared perfectly homogeneous, but at the magnification shown remaining cell structure is distinctly seen.

B. A cross section of coal from the mine of the Benton Coal Co., showing its general appearance. The anthraxylon strips, 2-a, 4-a, and 6-a, are compact and vitreous and reveal hardly any structure in cross section. In horizontal sections, however, the cell structure is clearly seen. The attritus consists of humic matter, some spore-exines, a little carbonaceous and earthy matter and much resinous matter.

\section{PLATE XCII.}

\section{THIN VERTICAL SECTIONS.}

A. A thin cross section of the coal from the Zeigler mine, Zeigler, Ill., showing the character of a larger anthraxylon component or bright coal, in cross section. The cell structure has been largely obliterated but is still recognizable; the fibers have been much flattened and intimately united. The piece is resinous, but the resinous inclusions are not well shown because in color and consistency they are much like the enveloping anthraxylon matter.

$B$. A typical thin cross section $(\times 200)$ of the Zeigler coal. The striations in the anthraxylon strip, 1-a are due to collapsed and intimately united cells. The remainder of the photograph represents a layer composed of many leaf cuticles, the residue of leaf tissues, spore matter, resinous and humic matter, and a tissue of a cork-like nature, particularly well represented at $3-d$; a similar tissue is shown at a higher magnification in Plate CX, $B$. 


\section{PLATE XCIII.}

THIN VERTICAL SECTIONS.

A. A thin cross section of the Zeigler coal, representing strips of anthraxylon. The strip 3-a is of the common type, in which the cells are much flattened and intimately united. 1-a is gnarly and granular and includes very large resinous particles.

B. A thin cross section of the Zeigler coal, showing at 1-a part of a decidedly homogeneous anthraxylon component in which cell structures are obscured. The presence of the structures can be demonstrated by various methods of illumination. The area $2-d$ to $4-d$ is composed of thin anthraxylon strips in which cell structures are clearly visible, containing a relatively large proportion of the cork-like tissue, other humic matter, and spore-exines.

\section{PLATE XCIV.}

THIN VERTICAL SECTIONS.

A. A typical thin cross section $(\times 200)$ of the Zeigler coal. 1-d is a row of spore-exines; $2-\mathrm{a}$ is a lamina of closely packed anthraxylon chips, homogeneous in appearance, in which the original cells may be recognized. At $3-d$ is a thin, light-colored lamina of spore-exines, and at 4-d to 5- $d$ a lamina com. posed of cork-like tissue, resinous degradation matter, leaf cuticles, and humic matter.

$B$. A thin cross section $(\times 200)$ of the Zeigler coal, showing the general nature of certain laminæ of the coal. At 1-d is a thin lamina composed of humic matter, spore-exines, and some of the cork-like tissues; just below this, at 2-c, are several cuticles and some spore-exines; at 2-a are anthraxylon strips. This is shown at higher magnification in Plate XCVI, $A$ and $B$. The remainder of the photograph shows attritus containing resinous matter, anthraxylon strips, humic matter, cuticles, and spore-exines. Notice the unusually small amount of carbonaceous matter.

\section{PLATE XCV.}

\section{THIN VERTICAL SECTIONS.}

A. Part of the section shown in Plate XCIV, $B(\times 1,000)$, taken from the middle of level 1-d, and showing spore-exines, humic matter, cork-like tissue, cuticles, and resinous particles in detail.

$B$. Part of the section shown in Plate XCIV, $B$, taken from the level $6-$ d. $(\times 1,000$. $)$

\section{PLATE XCVI.}

\section{THIN VERTICAL SECTIONS.}

$A$. Part of an area just outside of Plate XCIV, $B(\times 1,000)$, representing a humic lamina including several spore-exines and delicate cuticular matter.

$B$. Part of the same area $(\times 1,000)$, representing humic matter including several characteristic thick walled spore-exines, thin-walled exines, and cuticular matter. 